UNIVERSIDADE DE SÃO PAULO

FACULDADE DE ECONOMIA, ADMINISTRAÇÃO E CONTABILIDADE

DEPARTAMENTO DE CONTABILIDADE E ATUÁRIA

PROGRAMA DE PÓS-GRADUAÇÃO EM CIÊNCIAS CONTÁBEIS

\title{
EFICIENNCIA PRODUTIVA NO TERCEIRO SETOR: UM ESTUDO COMPARATIVO DE DESEMPENHO ENTRE ORGANIZAÇÕES FILANTRÓPICAS ASILARES
}

Marco Antonio Figueiredo Milani Filho Orientador: Prof. Dr. Welington Rocha

SÃO PAULO 
Profa. Dra. Suely Vilela

Reitora da Universidade de São Paulo

Prof. Dr. Carlos Roberto Azzoni

Diretor da Faculdade de Economia, Administração e Contabilidade

Prof. Dr. Fábio Frezatti

Chefe do Departamento de Contabilidade e Atuária

Prof. Dr. Edgard Bruno Cornachione Junior

Coordenador do Programa de Pós-Graduação em Ciências Contábeis 
Tese apresentada ao Departamento de Contabilidade e Atuária da Faculdade de Economia, Administração e Contabilidade da Universidade de São Paulo como requisito parcial para a obtenção do título de Doutor em Controladoria e Contabilidade.

Orientador: Prof. Dr. Welington Rocha

\section{SÃO PAULO}


Tese defendida e aprovada no Departamento de Contabilidade e Atuária da Faculdade de Economia, Administração e Contabilidade da Universidade de São Paulo - Programa de PósGraduação em Ciências Contábeis, pela seguinte banca examinadora:

\section{FICHA CATALOGRÁFICA}

Elaborada pela Seção de Processamento Técnico do SBD/FEA/USP

Milani Filho, Marco Antonio Figueiredo

Eficiência produtiva no terceiro setor: um estudo comparativo de desempenho entre organizações filantrópicas asilares / Marco Antonio Figueiredo Milani Filho. -- São Paulo, 2009. $220 \mathrm{p}$.

Tese (Doutorado) - Universidade de São Paulo, 2009 Bibliografia.

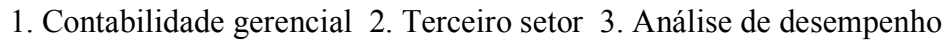
I. Universidade de São Paulo. Faculdade de Economia, Administração e Contabilidade. II. Título.

$$
\text { CDD }-658.151
$$



A todos aqueles que trabalham por uma sociedade baseada no comportamento ético, na alocação eficiente e eficaz de recursos e na valorização do mérito. 
Agradeço a Deus, pela existência e pelas oportunidades de desenvolvimento.

À minha família, pelo apoio, pela paciência e pelos incentivos constantes.

Ao Professor Dr. Welington Rocha, pelo privilégio de participar de suas aulas e de receber a sua orientação segura e presente, além da atenção respeitosa e motivação, imprescindíveis para a construção desta pesquisa.

Ao Professor Dr. Luiz João Corrar, que conta com a minha admiração e respeito por sua competência e por sua dedicação sincera à docência. Agradeço por suas valiosas contribuições durante a elaboração deste trabalho e pela indicação de vasto material de estudo.

Ao Professor Dr. Luciano Antonio Prates Junqueira, pelos comentários precisos e sugestões pertinentes durante a realização da banca de qualificação deste trabalho.

À Professora Dra. Silvia Pereira de Castro Casa Nova, por suas indicações de leitura e comentários.

Ao Professor Dr. Edson Luiz Riccio, da CCInt/USP, por sua contribuição decisiva para a minha participação na Carleton University/Canada na condição de pesquisador visitante.

Aos meus colegas Patrícia, Romildo, Formigoni, Oyadomari, Edmir e a todos os demais professores, alunos e funcionários da FEA/USP, com os quais compartilhei momentos de aprendizado e com quem estabeleci laços de respeito e amizade. 
"Não basta decretar a fraternidade e inscrevêla numa bandeira; é necessário, antes, mudar o coração dos Homens." Leon Denis 


\section{RESUMO}

Este trabalho objetivou classificar, sob a perspectiva da eficiência, as organizações filantrópicas asilares do estado de São Paulo, assim como investigar se o grau de dependência por recursos públicos e privados, os resultados financeiros e, também, o nível de disclosure dessas entidades guardaram relação significativa com o respectivo nível de eficiência produtiva. A amostra foi composta por 42 instituições de longa permanência para idosos (ILPIs) sediadas no estado de São Paulo, cujos dados de insumos (capital e trabalho) foram relacionados com seus produtos (representados pelos indicadores de desempenho estabelecidos pela Agência Nacional de Vigilância Sanitária - Anvisa), utilizando-se como período de referência o ano de 2008. O nível de eficiência relativa das entidades foi calculado através da Análise Envoltória de Dados (Data Envelopment Analysis - DEA) com retornos variáveis de escala e orientação aos insumos. As hipóteses de pesquisa foram testadas pela análise de regressão linear, cujas variáveis dependentes foram o grau de eficiência das ILPIs e as independentes foram valores nominais e por residente de: transferências públicas, receitas próprias e transferências privadas, receitas totais, resultados financeiros e disclosure. Os resultados apontaram que não existia relação estatisticamente significativa entre o grau de dependência por recursos públicos e o nível de eficiência, mas verificou-se que as variáveis resultado financeiro e grau de disclosure estão significativamente relacionadas com o nível de eficiência. Um ponto relevante sinalizado pela pesquisa foi o baixo grau de transparência e evidenciação de dados financeiros das ILPIs pesquisadas, as quais não divulgam alguns elementos considerados de publicação obrigatória pela atual legislação, refletindo a ausência de pressão, por parte de órgãos governamentais de fiscalização e por parte da própria sociedade civil, para a redução de assimetrias informacionais. Como parâmetro de referência, organizações eficientes servem de benchmark para as entidades que apresentam consumo excessivo de recursos diante de determinado desempenho, fato esse que sugere maior atenção dos stakeholders para que incentivem a melhoria de eficiência das entidades relacionadas. Considerando a escassez de trabalhos com abordagem quantitativa para a avaliação padronizada de desempenho de organizações do Terceiro Setor, este trabalho fomenta a discussão conceitual sobre a necessidade da adoção de elementos objetivos para alimentar os modelos decisórios para a alocação de recursos às organizações sem fins lucrativos. 


\begin{abstract}
This study aimed to classify, from the perspective of efficiency, the philanthropic organizations for elderly people in the State of São Paulo and to investigate whether the degree of dependence on public and private resources, earnings and also the level of disclosure of these entities are significantly related to the level of productive efficiency. The sample consisted of 42 long-stay institutions for elderly (ILPIS) based in the State of São Paulo, whose data inputs (capital and labor) were associated with their products (represented by the indicators of performance established by the National Sanitary Surveillance Agency - Anvisa), using as reference the year 2008. The level of relative efficiency of the organizations has been calculated by Data Envelopment Analysis (DEA) based on variable returns of scale and oriented input. The research hypotheses have been tested by linear regression analysis whose dependent variables were the degree of efficiency of ILPIs and the independent variables were the nominal and per resident values: government transfers, private transfers and revenue, total revenue, financial performance and disclosure. The results have not pointed out statistically significant relationship between the degree of dependence on public resources and the level of efficiency, but they have pointed out that both variables, earnings and degree of financial disclosure, are significantly related to the level of efficiency. A relevant issue raised by this research was the low level of transparency and disclosure of the ILPIs 'financial data, which do not disclose mandatory elements according to the current legislation, reflecting the lack of pressure from government surveillance and from civil society to the reduction of informational asymmetries. As a referential parameter efficient organizations work as benchmark for other organizations which present excessive consumption of resources facing certain performance, such a fact which suggests more attention from the stakeholders in order to motivate the efficiency of mentioned entities. Considering the scarcity of studies under a quantitative approach towards a standardized evaluation of the performance of Third Sector organizations, this work promotes the conceptual discussion on the necessity of adopting objective elements so as to feed the decision making models for the allocation of resources to nonprofitable organizations.
\end{abstract}




\section{SUMÁRIO}

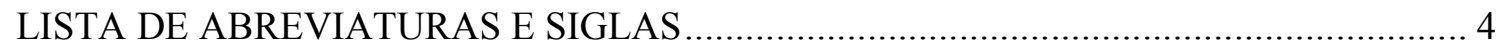

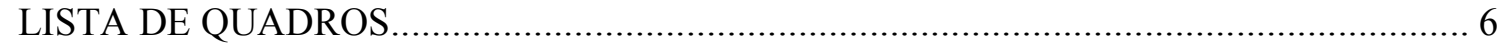

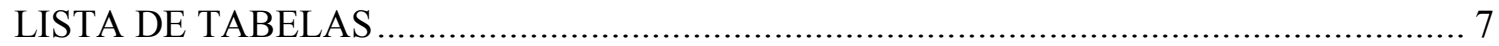

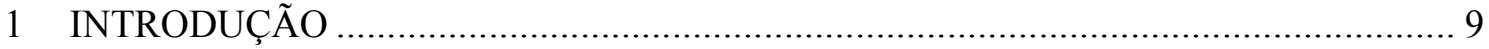

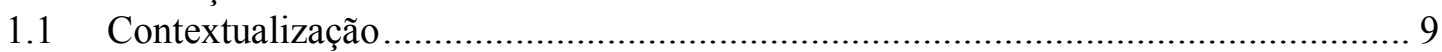

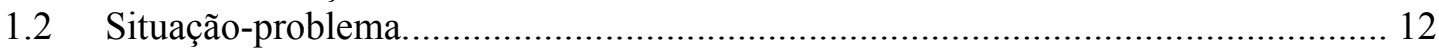

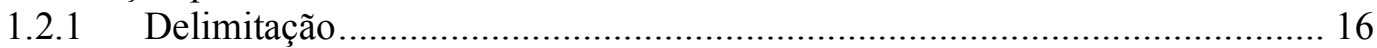

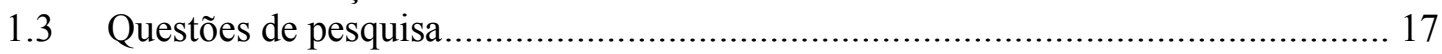

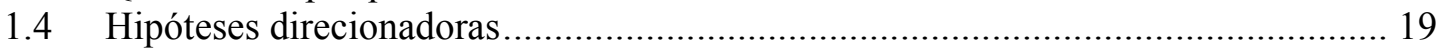

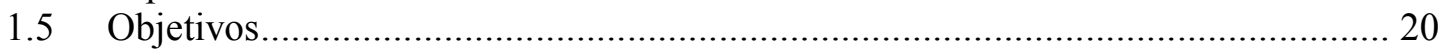

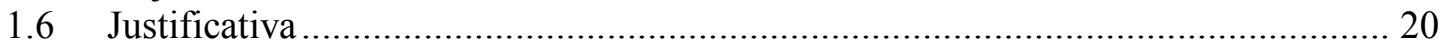

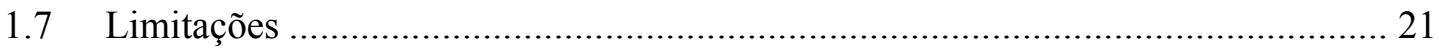

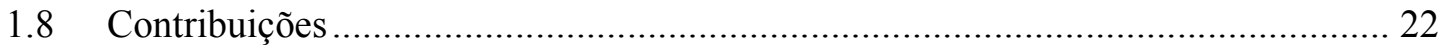

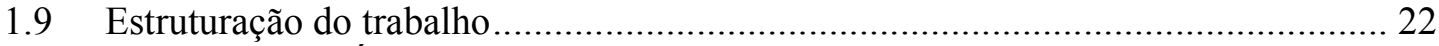

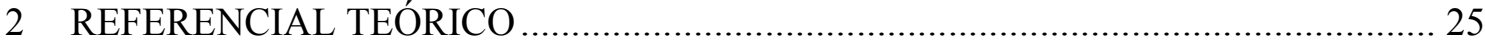

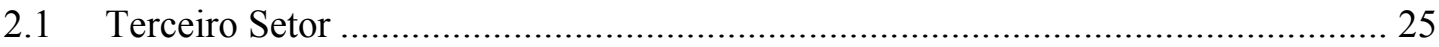

2.2 Caracterização das Organizações do Terceiro Setor ............................................. 29

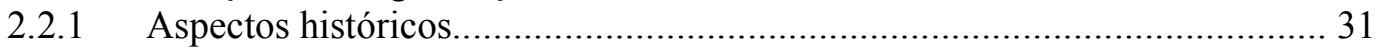

2.2.2 Principais núcleos de pesquisas acadêmicas sobre o Terceiro Setor .............. 33

2.2.3 Certificado de Entidade Beneficente de Assistência Social - CEBAS .......... 33

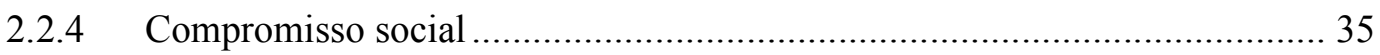

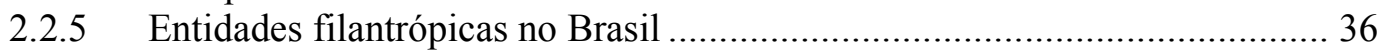

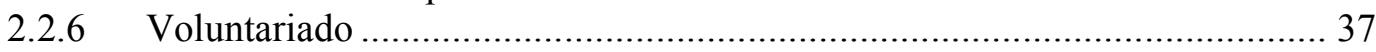

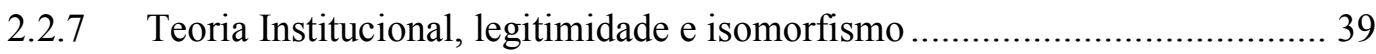

2.2.8 Aspectos contábeis das entidades filantrópicas ........................................ 41

2.2.8.1 Convergência contábil ...................................................... 43

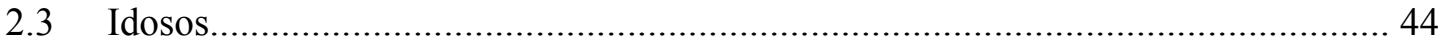

2.3.1 Instituições de Longa Permanência para Idosos - ILPIs.............................. 47

2.3.1.1 Alguns dados sobre as ILPIs no Brasil ...................................... 51

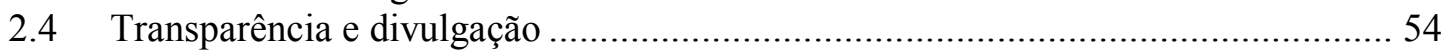

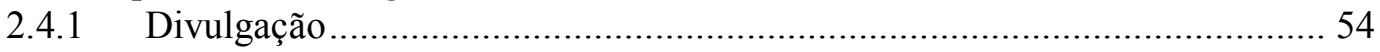

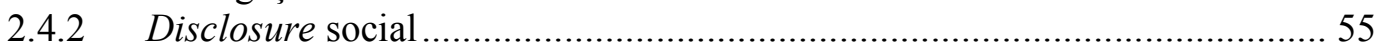

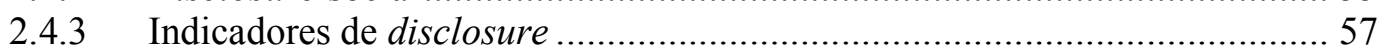

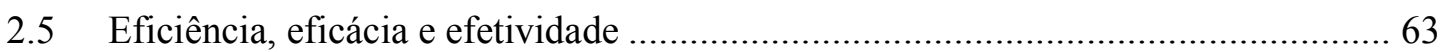

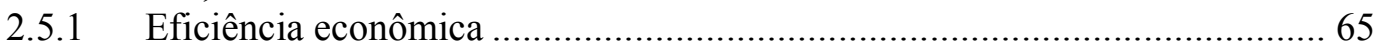

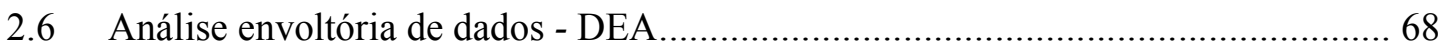

2.6.1 Comparação gráfica dos modelos CCR e BCC ….................................... 72

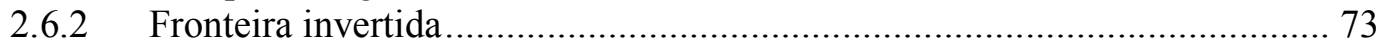

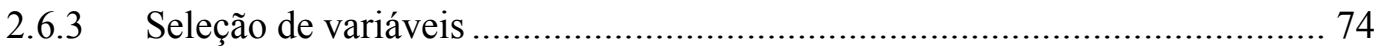

2.7 Restrição orçamentária fraca - Soft Budget Constraint ......................................... 75

2.7.1 Síndrome da Soft Budget Constraint ......................................................... 76

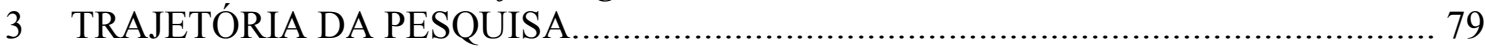

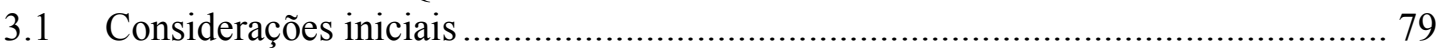

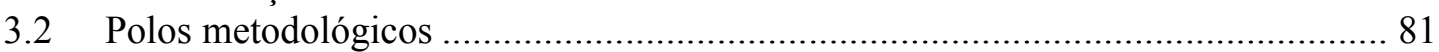

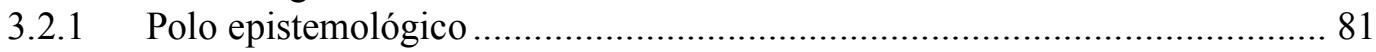

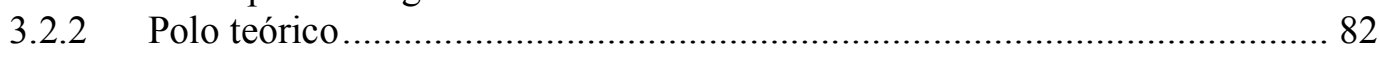

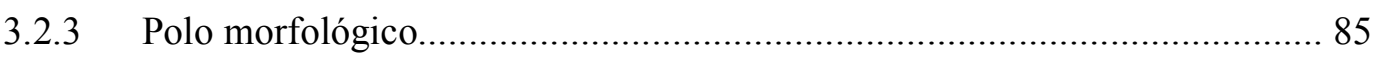




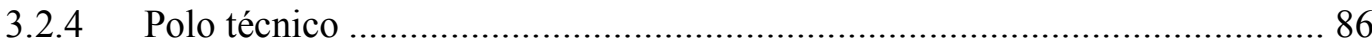

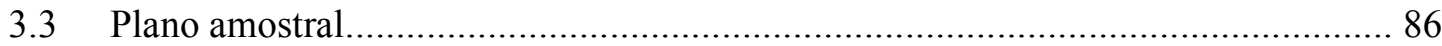

3.4 Mensuração do nível da eficiência produtiva das ILPIs .......................................... 88

3.4.1 Construção do indicador de eficiência …………........................................ 90

3.4.1.1 Indicadores relacionados aos produtos ......................................... 91

3.4.1.2 Indicadores relacionados aos insumos............................................ 92

3.4.1.3 Seleção das variáveis .................................................................. 94

3.5 Participação das receitas de origem estatal.......................................................... 98

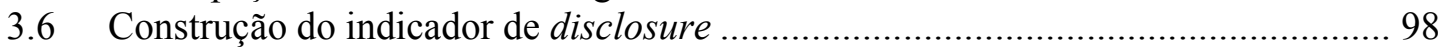

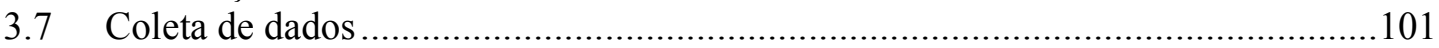

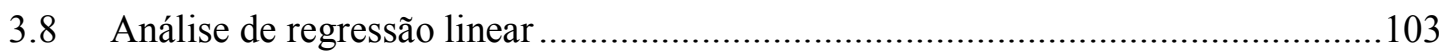

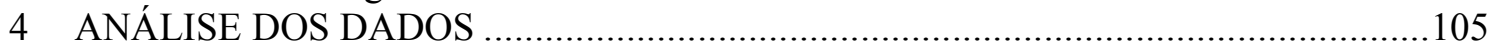

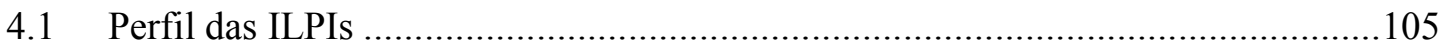

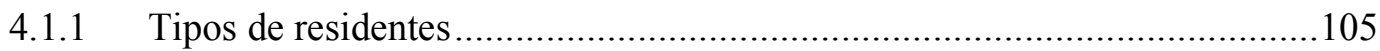

4.1.2 Trabalhadores remunerados e voluntários.................................................107

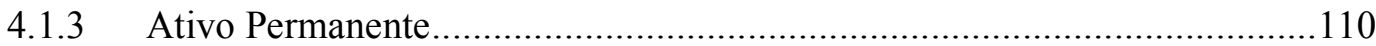

4.1.4 Despesas totais ................................................................................111

4.1.5 Indicadores de desempenho - Anvisa...................................................112

4.1.5.1 Mortalidade ..........................................................................112

4.1.5.2 Doença diarreica.................................................................112

4.1.5.3 Escabiose...........................................................................113

4.1.5.4 Desidratação ..............................................................................113

4.1.5.5 Úlcera de decúbito ...................................................................113

4.1.5.6 Desnutrição ..........................................................................114

4.1.6 Correlações entre dependência e trabalhadores .............................................114

4.1.7 Composição das receitas........................................................................115

4.1.8 Resultado (receitas - despesas) ...............................................................119

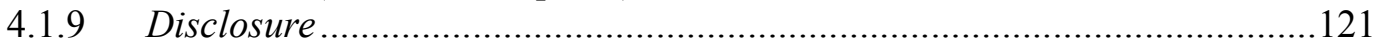

4.2 Estimativa das eficiências produtivas .............................................................122

4.2.1 Correlação entre eficiência e tipos de dependência ......................................125

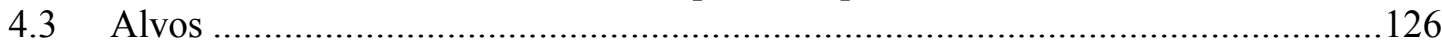

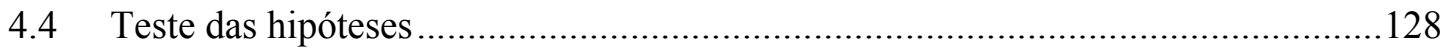

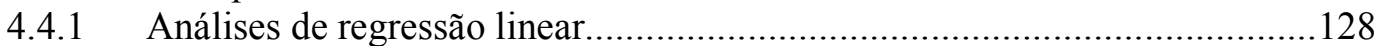

4.4.2 Transferências públicas ........................................................................130

4.4.2.1 Valor nominal das transferências públicas …………………….......130

4.4.2.2 Transferências públicas por residente...........................................131

4.4.2.3 Proporção das transferências públicas...........................................132

4.4.3 Receitas próprias e transferências privadas ...................................................133

4.4.3.1 Valor nominal das receitas próprias e transferências privadas ........134

4.4.3.2 Receitas próprias e transferências privadas por residente ................135

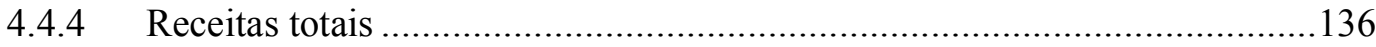

4.4.4.1 Valor nominal das receitas totais................................................136

4.4.4.2 Receitas totais por residente......................................................137

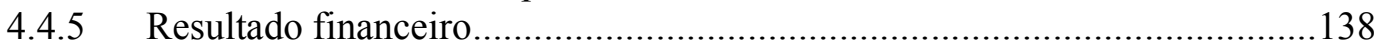

4.4.5.1 Valor nominal do resultado (receitas - despesas) ...........................138

4.4.5.2 Resultado (receitas - despesas) por residente ................................141

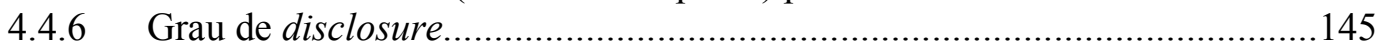

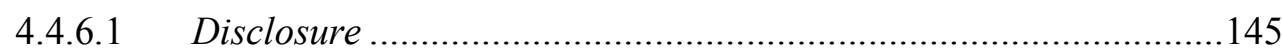

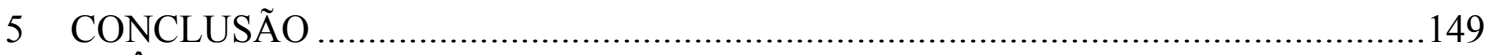

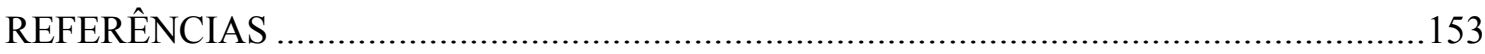




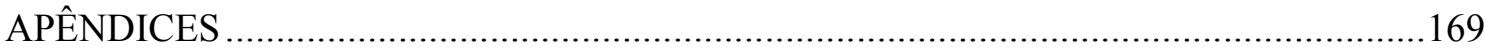

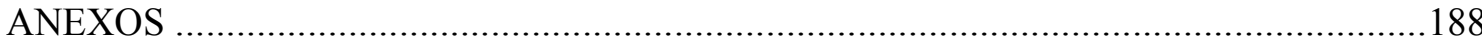




\section{LISTA DE ABREVIATURAS E SIGLAS}

ANVISA: Agência Nacional de Vigilância Sanitária

BCC: Banker, Charnes e Cooper

CCR: Charnes, Cooper e Rhodes

CEATS: Centro de Estudos em Administração do Terceiro Setor

CEBAS: Certificado de Entidade de Beneficência e Assistência Social

CETS: Centro de Estudos do Terceiro Setor

CFC: Conselho Federal de Contabilidade

CNAS: Conselho Nacional de Assistência Social

COFINS: Contribuição Financeira Social

COVISA: Coordenação de Vigilância em Saúde

CPC: Comitê de Pronunciamentos Contábeis

CRA: Canada Revenue Agency

CRS: Constant Return to Scale

CSL: Contribuição sobre o Lucro Líquido

CVSRD: Centre for Voluntary Sector Research and Development

DEA: Data Envelopment Analysis

DMU: Decision Making Unit

FGV: Fundação Getúlio Vargas

HBC: Hard Budget Constraint

IASB: International Accounting Standards Board

IBGE: Instituto Brasileiro de Geografia e Estatística

IFRS: International Financial Reporting Standards

ILPI: Instituição de Longa Permanência para Idosos

INSS: Instituto Nacional do Seguro Social

IPEA: Instituto de Pesquisas Econômicas Aplicadas

LBA: Legião Brasileira de Assistência

MDS: Ministério do Desenvolvimento Social

MEC: Ministério da Educação

MS: Ministério da Saúde

NBC-T: Norma Brasileira de Contabilidade Técnica

NEATS: Núcleo de Estudos Avançados do Terceiro Setor

NETS: Núcleo de Estudos do Terceiro Setor

OGSFL: Organização Governamental Sem Fins Lucrativos

OMS: Organização Mundial de Saúde

ONGCFL: Organização Não Governamental Com Fins Lucrativos

ONGSFL: Organização Não Governamental Sem Fins Lucrativos

OTS: Organizações do Terceiro Setor

PIB: Produto Interno Bruto

PIS: Programa de Integração Social

PROER: Programa de Estímulo à Reestruturação e ao Fortalecimento do Sistema Financeiro Nacional

PUC-SP: Pontifícia Universidade Católica de São Paulo

SBC: Soft Budget Constraint

SENAC: Serviço Nacional de Aprendizagem Comercial

SENAI: Serviço Nacional de Aprendizagem Industrial

SESC: Serviço Social do Comércio

SESI: Serviço Social da Indústria 
SPSS: Statistical Package for Social Sciences

USP: Universidade de São Paulo

VRS: Variable Return to Scale 


\section{LISTA DE QUADROS}

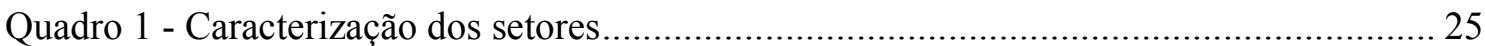

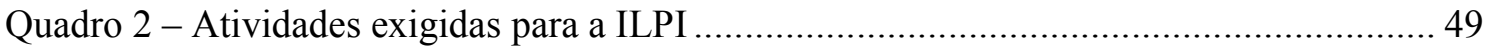

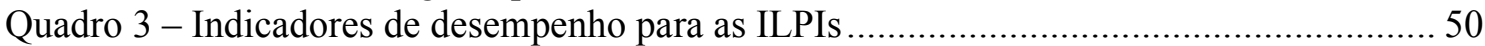

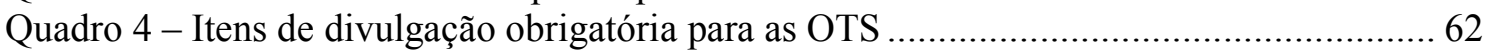

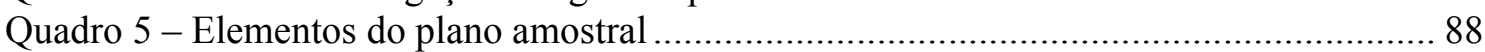

Quadro 6 - Variáveis relacionadas aos produtos ...................................................... 92

Quadro 7 - Principais variáveis relacionadas aos insumos na literatura consultada.............. 94

Quadro 8 - Quadro-resumo das variáveis relacionadas aos insumos e aos produtos..............97

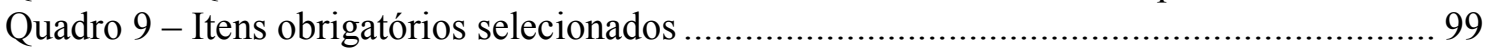

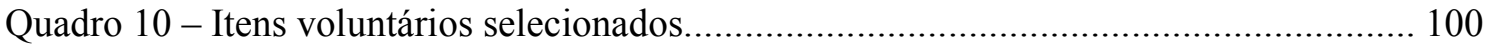




\section{LISTA DE TABELAS}

Tabela 1 - Quantidade de habitantes por entidade filantrópica ...................................... 37

Tabela 2 - Maior proporção da população idosa em países com mais de $10 \mathrm{MM}$ de pessoas 45

Tabela 3 - População total e de 60 anos ou mais - Brasil 2007 .......................................... 45

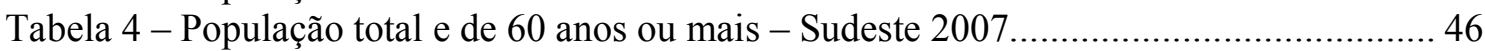

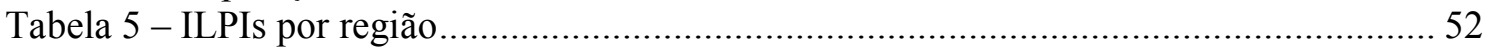

Tabela 6 - Características dos residentes por região ................................................... 52

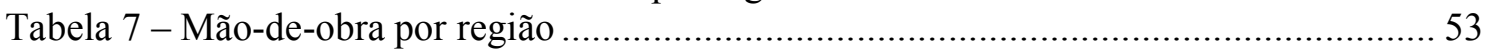

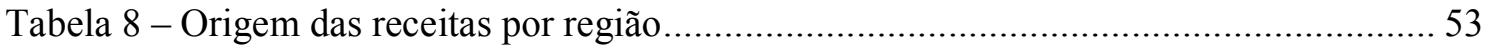

Tabela 9 - Características das despesas por região ...................................................... 53

Tabela 10 - Principais informações utilizadas em indicadores de disclosure voluntário ....... 59

Tabela 11 - Variáveis relacionadas ao desempenho de ILPIs ....................................... 95

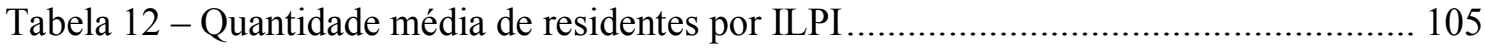

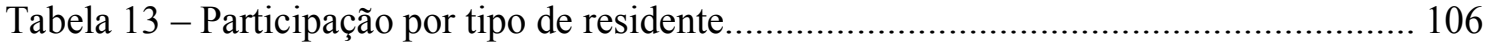

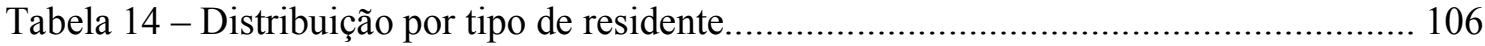

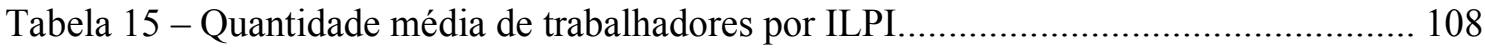

Tabela 16 - Horas remuneradas e voluntárias por residente............................................ 109

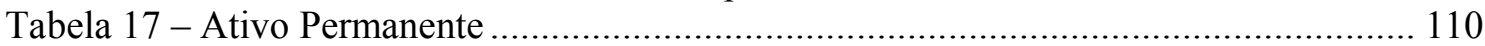

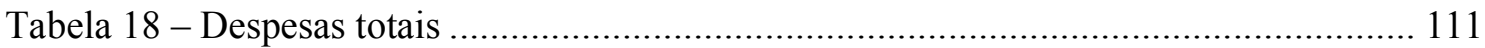

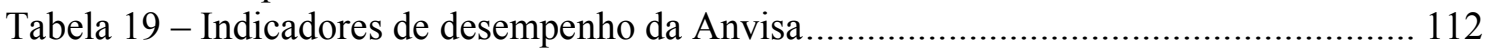

Tabela 20 - Correlações entre dependência e trabalhadores ......................................... 114

Tabela 21 - Composição da receita nominal ............................................................. 115

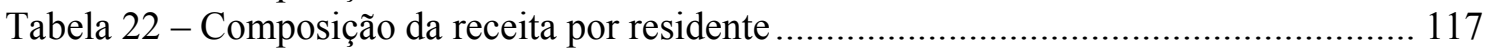

Tabela 23 - Participação das receitas públicas e privadas................................................. 118

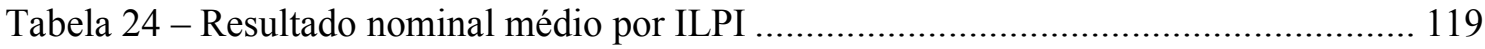

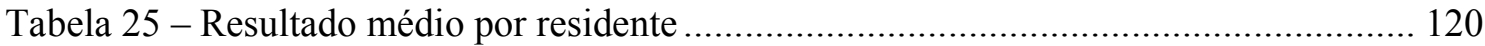

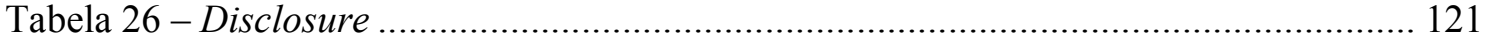

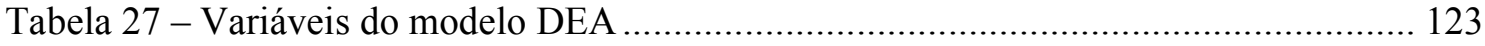

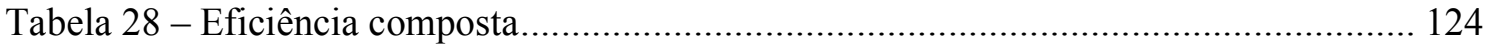

Tabela 29 - Correlação entre eficiência e quantidade de residentes, por tipo. ..................... 125

Tabela 30 - Correlação entre eficiência e distribuição de residentes, por tipo..................... 125

Tabela 31 - Valores atuais de inputs e outputs das ILPIs ineficientes ................................ 126

Tabela 32 - Alvos de inputs e outputs das ILPIs ineficientes........................................ 126

Tabela 33 - Diferenças entre os valores atuais e os alvos das ILPIs ineficientes ................ 127 


\section{INTRODUÇÃO}

\subsection{Contextualização}

O estudo do Terceiro Setor, por diferentes ramos do conhecimento e com abordagens diversificadas, expressa o propósito científico e interdisciplinar para a compreensão desse fenômeno social, o qual vem recebendo crescente atenção da comunidade acadêmica, da iniciativa privada, do Estado e da população em geral.

Ao recortar e isolar o objeto de estudo, o cientista vislumbra apenas alguns aspectos da realidade e depende de teorias prévias para entender e explicar esse objeto. Nesse sentido, o Terceiro Setor e suas entidades são observados sob diferentes lentes teóricas, mas ainda se mostram carentes por pesquisas que contribuam para o entendimento efetivo de suas origens, estruturação, funcionamento e interação com o Estado (Primeiro Setor) e o mercado (Segundo Setor).

Seja pelo reconhecimento público da relevância de seus serviços prestados para o atendimento de diversas demandas sociais, seja, ainda, pela participação crescente na dimensão econômica nacional e internacional, é premente a compreensão em profundidade dos aspectos relacionados ao planejamento, operacionalização, desempenho e controle das organizações não-governamentais sem fins lucrativos (também denominadas Organizações do Terceiro Setor - OTS).

Uma consequência da ausência de instrumental teórico consolidado para o estudo das OTS sob o aspecto econômico-financeiro é o uso adaptado de conceitos inicialmente desenvolvidos para entidades de mercado, mas que apresentam limitações quando aplicados num contexto onde o superávit contábil não é, necessariamente, um indicador de sucesso. A finalidade de um empreendimento social, por exemplo, não é maximizar o lucro ou a riqueza de qualquer pessoa ou de um grupo em particular, diversamente ao que se poderia sugerir sob uma abordagem microeconômica limitada para empresas de mercado. Mas o fato de não ter como objetivo principal declarado a obtenção de lucros não impede a análise de uma organização sem fins lucrativos servindo-se de conceitos da Teoria da Firma, considerando-se variáveis específicas para esse ambiente. 
Seja por falha de mercado, incapacidade ou, ainda, pela combinação desses e outros fatores, a mobilização da sociedade civil para atuar de maneira organizada na comunidade é um fato inconteste. Conforme o Instituto Brasileiro de Geografia e Estatística (IBGE, 2005), existem no Brasil cerca de 338 mil OTS, as quais empregam 1,7 milhão de trabalhadores remunerados. Segundo o Instituto de Pesquisas Econômicas Aplicadas (IPEA, 2005), o Terceiro Setor representa 1,5\% do Produto Interno Bruto - PIB nacional. Tais entidades são associações, fundações e organizações religiosas com diversificados focos de atuação.

O Terceiro Setor no Brasil, entretanto, ainda não apresenta a mesma participação econômica que a verificada em outros países mais desenvolvidos. Nos Estados Unidos e no Canadá, por exemplo, esse setor representa, respectivamente, 7,5\% e 6,9\% do Produto Nacional Bruto, segundo dados do Centre for Voluntary Sector Research and Development (CVSRD, 2006), fato esse que permite vislumbrar o potencial de crescimento brasileiro nesse campo. Destacase que, apesar de realidades socioeconômicas diferentes, países com regimes democráticos e com garantias de liberdade de expressão de seus cidadãos favorecem a manifestação de iniciativas privadas com finalidades públicas (SEN, 2004).

Uma vez estabelecidas, as OTS direcionam seus esforços operacionais para cumprir a missão social que justifica a própria existência. Sob esse propósito, poderão atrair recursos públicos e privados para a respectiva manutenção, além de se beneficiarem de imunidade e/ou isenções fiscais previstas pela legislação vigente. A credibilidade de uma instituição perante seus mantenedores e potenciais doadores torna-se, portanto, um valioso bem (GLAESER, 2003).

Elementos da Teoria Institucional, desenvolvidos desde os anos 50 por Selznick (1957) e, posteriormente, por autores como Meyer e Rowan (1977), Dimaggio e Powell $(1983,1991)$ e Scott (1995), contribuem para a discussão dos motivos que levam as organizações a adotarem comportamentos isomórficos num ambiente de incertezas. Sob esse prisma, as OTS podem tentar conquistar e manter a credibilidade junto aos stakeholders pela disponibilização pública de determinadas informações porque outras entidades assim o fazem, ainda que a simples divulgação não permita conhecer seu nível de eficiência. A adoção de instrumentos para a prestação de contas (accountability) e a evidenciação (disclosure) de informações das OTS pode estar relacionada com o comportamento mimético ou isomórfico entre as próprias organizações. 
De acordo com Cutt e Murray (2000, p. xiii), "A base da mensuração de desempenho, avaliação e emissão de relatórios é a accountability." Tal ênfase é uma consequência do papel essencial que a accountability possui no relacionamento entre uma organização e suas diferentes partes interessadas. A obrigação de prestar contas de uma responsabilidade conferida implica, em um sentido geral, medir o desempenho, avaliar atividades e preparar relatórios para dar suporte a decisões de algum tipo. A condição para monitorar a organização e edificar sua confiança perante a sociedade civil liga-se, portanto, diretamente à accountability.

O tipo de informação que os tomadores de decisões têm ao seu dispor, aliando-se ao que eles realmente gostariam de ter, influenciarão o relacionamento entre eles e a entidade. O nível de accountability é afetado, consequentemente, pela pressão a que a organização está sujeita por parte dos grupos de interesse externos e internos (CUTT; MURRAY, 2000).

Sob uma perspectiva financeira, o valor de uma empresa de mercado depende significativamente das expectativas que os acionistas e os potenciais investidores têm sobre seus resultados futuros. Assim, a assimetria informacional entre os stakeholders e a própria entidade gera incerteza e aumenta o risco relacionado à estimativa de desempenho da companhia, afetando seu preço de mercado. As ferramentas de accountability, neste caso, ofereceriam elementos para reduzir a assimetria informacional. Por sua vez, as OTS deveriam receber uma abordagem específica, considerando-se seus objetivos sociais, porque esses transcendem os aspectos econômico-financeiros.

Os doadores de recursos que não possuam informações públicas suficientes para avaliar o desempenho das OTS podem estar alimentando entidades que apresentam superávits financeiros, mas são caracterizadas como ineficientes economicamente, como já apontado em pesquisas anteriores (MILANI FILHO, 2006). Essa situação pode fazer com que recursos escassos não sejam alocados para entidades e projetos sociais que representem as melhores opções dentre as disponíveis, sob a ótica econômica. Caracteriza-se, assim, o custo de oportunidade da própria sociedade ante os diferentes projetos alternativos (SLOMSKI, 1996).

O problema econômico central de qualquer economia é alocar os recursos de maneira eficiente visando ao bem-estar coletivo (SAMUELSON; NORDHAUS, 2004). No Brasil, um 
país que apresenta indicadores não-equitativos de distribuição de renda em que $31,7 \%$ da população vivem com renda domiciliar per capita inferior a meio salário mínimo por mês (IPEA, 2005), espera-se que a administração pública e a sociedade civil contribuam para a redução de privações sociais, econômicas e políticas. Os doadores e financiadores de recursos nas esferas pública ou privada são os responsáveis por essas alocações.

\subsection{Situação-problema}

Sob a ótica econômica, a transferência de recursos por agentes racionais para alguma OTS é uma decisão que objetiva a maximização de interesses dos agentes doadores e financiadores, sejam esses estatais ou privados, pessoas físicas ou jurídicas. Independente da explicitação desses interesses, que podem ter caráter financeiro (como, por exemplo, no caso de crédito concedido por um fornecedor para venda a prazo) ou não-financeiro (como, por exemplo, a doação de mão-de-obra por trabalhadores voluntários), esses stakeholders são partes nas transações efetuadas e, assim, podem desejar conhecer e acompanhar como os recursos recebidos estão sendo utilizados.

O Estado tem interesse direto na manutenção e fiscalização das OTS, considerando que essas prestam serviços públicos e colaboram para o cumprimento dos deveres do próprio Estado perante os seus cidadãos. Além disso, a transferência de recursos públicos para uma entidade na forma de subvenção, por exemplo, representa a opção de não direcionar recursos escassos para outras áreas ou organizações da sociedade. Perante entidades semelhantes, a decisão econômica racional de um provedor consideraria a alocação de recursos àquelas que pudessem ser mais eficientes e eficazes no cumprimento de seus objetivos sociais. Nesse sentido, é pertinente a existência de modelos e instrumentos avaliativos que permitam orientar a alocação de recursos financeiros e não-financeiros para as entidades que mais possam beneficiar a sociedade utilizando a menor quantidade dos recursos escassos.

Ao incentivar organizações que contribuam para o atendimento das demandas sociais, o Estado pode tornar-se o maior fornecedor de recursos para algumas delas, criando uma situação de dependência econômica. Sob a perspectiva teórica da Soft Budget Constraint SBC, proposta inicialmente por Kornai (1980, 1986), as entidades que possuem maior probabilidade de contar com fontes de recursos externas para o suprimento de maneira parcial 
ou integral da deficiência financeira gerada pelas operações tendem a relaxar suas restrições orçamentárias e tornarem-se ineficientes. Essa situação é tipicamente encontrada em Estados que apresentam comportamentos paternalistas.

A grande diversidade de tipos de OTS existentes faz com que não se possa tratá-las como um grupo homogêneo com relação às características de seus respectivos objetos. O que as une, genericamente, é o caráter não governamental e a declaração estatutária de não terem fins lucrativos. No Brasil, a manutenção do status de entidade com benefícios fiscais segue, basicamente, a verificação da conformidade legal de suas ações e da disponibilização das informações obrigatórias (BARBOSA, 2001; SZAZI, 2006). O mesmo ocorre, por exemplo, no Canadá (CRA, 2008), em que a Canada Revenue Agency - CRA (equivalente à Receita Federal brasileira) verifica, apenas, se as organizações registradas seguem o Income Tax Act, independentemente do nível de eficiência obtido por elas. A ênfase do monitoramento realizado pelos órgãos públicos competentes recai, dessa maneira, na verificação do cumprimento dos requisitos legais para o funcionamento, sem a utilização padronizada de um modelo comparativo de eficiência entre elas que seja baseado nas atividades operacionais e nos resultados obtidos.

Com relação ao segmento filantrópico, existem cerca de sete mil entidades oficialmente registradas no Brasil (MDS, 2009), as quais detêm o Certificado de Entidade de Beneficência e Assistência Social (CEBAS) que lhes garante reconhecimento oficial e tratamento fiscal específicos. O Conselho Nacional de Assistência Social (CNAS), vinculado ao Ministério do Desenvolvimento Social (MDS), assim como os Ministérios da Educação e da Saúde, são os órgãos encarregados da fiscalização dessas entidades para a certificação e manutenção do CEBAS. Legalmente, as entidades filantrópicas são obrigadas a prestar contas ao Estado devido à função social que exercem e, principalmente, porque tais organizações podem receber verbas públicas e emitir recibos para abatimentos fiscais de doadores privados. $\mathrm{O}$ CNAS, a Receita Federal e os Ministérios envolvidos, entretanto, não oferecem informações públicas sobre o desempenho e a eficiência dessas organizações, centrando seu acompanhamento na conformidade legal de determinados critérios administrativos e operacionais. Os atuais critérios permitem o cálculo de alguns quocientes financeiros e operacionais, mas são insuficientes para o estabelecimento de um ranking sobre a eficiência produtiva das organizações, considerando-se múltiplos insumos e múltiplos produtos. 
Qualquer organização filantrópica pode utilizar modelos avaliativos próprios ou baseados em outros já existentes, mas isso não implica que as informações sobre seu desempenho e sua eficiência sejam disponibilizadas ao público para reduzir o grau de assimetria existente entre a organização e seus stakeholders externos. A transparência e a presença de mecanismos de governança são elementos a serem aprimorados no Terceiro Setor brasileiro.

Estudos anteriores, como os de Klein (1998), Dyl et al. (2000), Desai e Yetman (2006) nos Estados Unidos, Callen et al. (2003) no Canadá, e Jobome (2006) no Reino Unido, sinalizaram a existência de relação positiva entre o desempenho de entidades filantrópicas e determinados mecanismos de governança (como, por exemplo, o uso de comitês especializados e a separação de função entre controle estratégico e execução). Considerandose que a accountability, entendida como a obrigação de prestar contas sobre alguma responsabilidade conferida, ocorre no contexto da governança (LeCLERC, 1996), é de se esperar que também se apresente uma relação positiva entre os mecanismos de accountability e o desempenho das organizações. Supostamente, as organizações com maiores exigências de prestação de contas a seus stakeholders deveriam ter um desempenho mais favorável do que aquelas com menores exigências. Jobome (2006), por exemplo, constatou que as entidades caritativas inglesas que recebiam verbas públicas e, consequentemente, se submetiam a um monitoramento estatal mais criterioso, apresentavam maior eficiência organizacional do que aquelas que não estavam sujeitas ao mesmo grau de obrigatoriedade de prestação de contas. No caso inglês, a ação estatal de monitoramento e a pressão por resultados favoreceram o desempenho das organizações, sem relaxar as restrições orçamentárias. Devido ao fato de contar com a transferência de recursos de fontes públicas e privadas, supõe-se que a sociedade civil e os governantes desejam conhecer quais são as entidades mais eficientes, para favorecer o processo decisório sobre a alocação de recursos.

Sob a ótica administrativa, os próprios gestores de OTS necessitam de informações de entidades semelhantes que lhes permitam monitorar o desempenho e colaborar para a fixação de metas operacionais, pois, segundo Tongel e Petrescu (2004), o processo de benchmarking representa relevante papel nesse intento.

A situação-problema identificada desenha-se na indisponibilidade de modelos informacionais aos provedores de recursos, ao público em geral e aos gestores das OTS que permitam 
conhecer o desempenho comparativo e a eficiência produtiva dessas organizações servindo-se de critérios objetivos.

Dessa maneira, ainda que as organizações possuam mecanismos de governança e accountability e, ainda que utilizem modelos avaliativos do próprio desempenho, sem a análise comparativa de eficiência, os stakeholders não terão elementos objetivos para direcionar recursos às entidades mais eficientes e os gestores das OTS não possuirão benchmarks para aumentar o nível de eficiência da entidade. Além disso, o grau de dependência que essas entidades podem possuir junto às fontes estatais, sem incentivos para o aprimoramento do desempenho, pode gerar o relaxamento de suas restrições orçamentárias e contribuir para a redução de eficiência.

Na bibliografia consultada inexistem pesquisas que tratem, simultaneamente, da relação entre o grau de dependência por recursos públicos das OTS, o nível de disclosure e a eficiência produtiva.

Devido à escassez, na literatura, de modelos aplicados para se comparar a eficiência entre essas organizações através de critérios objetivos, uma situação possível de ser encontrada é a presença de instrumentos de prestação de contas e a adoção de práticas de disclosure nas entidades, mas sem a relação positiva com a eficiência produtiva, pois esses elementos podem estar presentes como um reflexo isomórfico, sob a ótica da Teoria Institucional.

Considerando, ainda, que a legislação brasileira que rege o registro e a manutenção do status de entidade filantrópica não obriga a adoção de modelos informacionais para a avaliação e comparação de eficiência entre as entidades, pode-se levantar a questão que, se o Estado for o principal responsável pela transferência de recursos a determinadas organizações, então o grau de eficiência destas poderá ser inferior ao daquelas que também contam com fontes de origem privada e geração própria de recursos, uma vez que essas últimas também são, supostamente, pressionadas a prestar contas para outros provedores e não relaxariam as restrições orçamentárias. 


\subsubsection{Delimitação}

Para Marconi e Lakatos (1996), a delimitação da pesquisa pode ocorrer sob três principais enfoques: ao assunto, à extensão e a fatores diversos. Ao se delimitar o assunto, pretende-se selecionar um tópico, a fim de impedir que esse se torne muito amplo e superficial. A delimitação da extensão ocorre diante da impossibilidade de se abranger todo o âmbito geográfico em que o fato se desenrola. E, finalmente, pode-se delimitar a pesquisa por fatores diversos que podem restringir o campo de ação, como recursos econômicos, exigibilidade de prazo e indisponibilidade de dados.

$\mathrm{O}$ assunto Terceiro Setor, por suas próprias características, permite o desenvolvimento de diferentes tópicos e em diferentes níveis de abrangência como, por exemplo: seu aspecto como fenômeno histórico e social no planeta, o seu relacionamento com o Estado e o mercado, sua participação econômica nas sociedades, características e desempenho de suas organizações, mensuração do resultado econômico das OTS, entre muitos outros.

Como parte da estratégia desta pesquisa, a delimitação do assunto focou, de maneira direta, a eficiência das organizações e, indiretamente, a eficácia e efetividade. A opção pela eficiência decorreu da priorização de dados objetivos e quantitativos para se realizar a análise comparativa das entidades alternativamente à utilização de dados qualitativos, mais subjetivos. Além disso, a relação entre os produtos gerados e os insumos utilizados influencia a eficácia e o nível de efetividade (aqui entendido como o alcance das ações realizadas em determinado ambiente).

A investigação de aspectos relacionados à eficiência exige um recorte entre as próprias OTS que permita comparar o nível de utilização dos insumos relacionados a produtos homogêneos. Dentre as bases de dados consultadas, constatou-se que um dos segmentos do Terceiro Setor com informações cadastrais disponíveis de todas as suas organizações é o filantrópico. Outro ponto favorável para a escolha desse segmento é o fato de que todas as suas entidades, independentemente do porte ou área de atuação, devem ter, obrigatoriamente, demonstrações financeiras auditadas, a fim de manterem os benefícios fiscais previstos pela legislação. As organizações filantrópicas atuam somente em três áreas: assistência social, saúde e educação. Esse fato também auxilia o recorte necessário para este trabalho, mas ainda se fez necessária a seleção dos tipos de entidade que tivessem homogeneidade de seus produtos. Dentre as organizações pesquisadas nas três áreas (saúde, educação e assistência social), constatou-se 
que aquelas voltadas ao público de idosos eram adequadas para o desenvolvimento desta pesquisa, pois os seus produtos básicos devem apresentar características definidas pela legislação em vigor, favorecendo a respectiva homogeneização.

Simultaneamente, procurou-se levantar os aspectos relacionados à relevância do objeto social promovido pelas Instituições de Longa Permanência para Idosos - ILPIs no panorama nacional e internacional. Verificou-se que se trata de uma das preocupações prementes no cenário global devido ao aumento da expectativa de vida e à redução das taxas de natalidade da população mundial, com consequências sociais, econômicas e políticas significativas. No Brasil, particularmente, os habitantes com mais de 60 anos, os quais representavam $8,6 \%$ da população em 1996, representaram 10,2\% em 2006 e representarão 11,4\% em 2020 (IBGE, 2006), com tendência crescente.

Para delimitar-se a área geográfica desta pesquisa, optou-se pelo Estado de São Paulo, o qual é a unidade federativa que reúne a maior população brasileira de idosos, com $23 \%$ do total nacional (IBGE, 2007).

Assim, para este estudo, as unidades de análise escolhidas foram as ILPIs certificadas oficialmente como filantrópicas e sediadas no Estado de São Paulo, considerando a homogeneidade dos serviços básicos oferecidos, que favorece a comparabilidade da eficiência entre elas e, também, pela relevância social e econômica que possuem ao atender um público com tendência crescente de participação na sociedade e que demandará, em decorrência, maiores volumes de investimentos estatais e privados.

\subsection{Questões de pesquisa}

Segundo Koche (1997, p.108), uma questão de pesquisa é “[...] um enunciado interrogativo que questiona sobre a possível relação que possa haver entre, ao menos, duas variáveis, pertinentes ao objeto de estudo investigado e passível de teste ou observações empíricas." Kerlinger (1980, p.35) também entende que a questão do estudo científico é uma pergunta sobre como as variáveis estão relacionadas. 
Necessitando-se trabalhar com conceitos precisos, a formulação de uma ou mais questões de pesquisa deve ser feita com a intenção de se definir os fenômenos que possam assumir a forma de uma variável dependente a ser relacionada com uma ou mais variáveis independentes.

O ponto central deste trabalho vinculou-se à possibilidade do uso de um modelo quantitativo (Análise Envoltória de Dados) baseado em critérios objetivos para avaliação de desempenho de entidades filantrópicas, capaz de:

a) permitir a comparação entre as organizações;

b) apontar valores de referência relacionados aos insumos e produtos para o incremento da eficiência das organizações consideradas ineficientes;

c) oferecer elementos informacionais relevantes para o processo decisório de doadores de recursos e de outros stakeholders.

Posteriormente, buscou-se verificar a existência de relação significativa entre a eficiência produtiva e a participação de recursos públicos e privados na Receita Total, assim como a relação entre a eficiência produtiva e o nível de disclosure das organizações estudadas, estabelecendo-se as seguintes variáveis:

- variável dependente: Eficiência produtiva das Instituições Filantrópicas Paulistas de Longa Permanência para Idosos.

- variáveis independentes: a) Receitas nominais decorrentes de transferências públicas;

b) receitas decorrentes de transferências públicas por residente;

c) receitas nominais próprias, decorrentes de prestação de serviços e comercializações, somadas com outras receitas nominais de origem privada;

d) receitas próprias somadas com outras receitas de origem privada divididas pela quantidade de residentes;

e) resultado financeiro nominal (receitas totais menos despesas totais);

f) resultado financeiro (receitas totais menos despesas totais) por residente;

g) nível de disclosure. 
As questões que nortearam esta pesquisa foram:

I. Quais são os valores de referência relacionados aos insumos e produtos das Instituições Filantrópicas Paulistas de Longa Permanência para Idosos consideradas mais eficientes?

II. Há relação significativa entre o nível de eficiência produtiva e a proporção de recursos públicos na receita das organizações analisadas?

III. Há relação significativa entre o nível de eficiência produtiva e o resultado financeiro (receitas totais menos despesas totais) por residente das organizações analisadas?

IV. Há relação significativa entre o nível de eficiência produtiva e o nível de disclosure das organizações analisadas?

\subsection{Hipóteses direcionadoras}

O sentido etimológico da palavra grega hypothesis é "colocar por baixo" (MAGALHÃES, 2005, p.175), designando uma proposição que atuará como ponto de apoio em uma investigação. Trata-se de uma suposição de verdade para se responder provisoriamente a um problema com a finalidade de ajudar a orientar a pesquisa.

No entendimento de Ferrari (1982) e Lakatos e Marconi (2000), a hipótese é concebida como uma proposição antecipadora à comprovação da realidade existencial, ou seja, é uma pressuposição que antecede a constatação dos fatos. Assim, as hipóteses devem ser testadas e é essa condição que corrobora o caráter de cientificidade da pesquisa.

Por depender exclusivamente de levantamento empírico de dados e diante da inexistência de informações históricas específicas na literatura disponível, não é pertinente a antecipação de resultados para a questão de pesquisa I. Para responder de maneira preliminar e temporária às questões II, III e IV foram elaboradas as seguintes hipóteses:

○ H1: Quanto maior o grau de dependência por recursos públicos, menor é o nível de eficiência produtiva das instituições filantrópicas de longa permanência para idosos do Estado de São Paulo. 
○ H2: Quanto maior o resultado financeiro (receitas - despesas), maior é o nível de eficiência produtiva das instituições filantrópicas de longa permanência para idosos do Estado de São Paulo.

- H3: Quanto maior o nível de disclosure, maior é o nível de eficiência produtiva das instituições filantrópicas de longa permanência para idosos do Estado de São Paulo.

\subsection{Objetivos}

O objetivo geral deste estudo, conectado diretamente às questões de pesquisa, é classificar, sob a perspectiva produtiva, as ILPIs filantrópicas paulistas conforme os respectivos níveis de eficiência, assim como investigar se o grau de dependência por recursos públicos e privados, os resultados financeiros e o nível de disclosure dessas organizações guardam relação significativa com sua eficiência produtiva.

Os objetivos específicos, os quais advêm do objetivo geral e se atêm a aspectos particulares do fenômeno estudado, são:

- Propor um modelo avaliativo de desempenho para ILPIs baseando-se em variáveis objetivas.

- Comparar a eficiência produtiva de ILPIs filantrópicas paulistas e apontar referências métricas para o aumento da respectiva eficiência.

\subsection{Justificativa}

Conforme Martins (1994, p. 20), a pesquisa deve tratar de um tema que seja, ao mesmo tempo, original, importante e viável.

A importância do tema deste estudo relaciona-se a uma questão que, dentre outras particularidades, pode polarizar ou afetar um segmento substancial da sociedade. Nesta pesquisa, a relevância repousa sobre a própria questão social abordada, pois o direcionamento e o consumo adequados de recursos escassos da comunidade por entidades que, supostamente, deveriam contribuir para o bem-estar da sociedade, é a expectativa de governantes, doadores e 
cidadãos em geral. Adicionalmente, as mobilizações políticas para a alteração da legislação sobre as organizações da sociedade civil, objetivando o aperfeiçoamento dos mecanismos de controle para mitigar o risco de fraudes e uso indevido do erário público, torna o tema desta pesquisa atual e pertinente.

O Terceiro Setor e suas organizações são objetos estudados pela comunidade científica internacional há algumas décadas, principalmente nos países considerados desenvolvidos. No Brasil, entretanto, a produção acadêmica sobre o assunto é reduzida se comparada à atenção que outros setores recebem, o que faz com que as pesquisas que contribuam para a compreensão dos mecanismos e dos atores desse ambiente sejam necessárias e atuais.

Considerando a escassez de trabalhos científicos sobre o desempenho de instituições filantrópicas no Brasil e a ausência de bases de dados nesse sentido, este estudo agrega informações objetivas relevantes, com aspectos de originalidade. Os resultados obtidos oferecem informações de interesse para novas pesquisas e fomentam o debate sobre a eficiência e a contribuição das demais organizações do Terceiro Setor brasileiro.

A viabilidade liga-se ao desenvolvimento de um trabalho exequível, ou seja, é o estudo que reúne condições para ser iniciado, desenvolvido e concluído, conforme os prazos e recursos disponíveis e necessários, e cujas evidências empíricas permitam observações, testes e validações dos possíveis achados da investigação. Esta pesquisa tornou-se viável considerando-se a delimitação das entidades a serem estudadas, do conhecimento do prazo e dos recursos necessários para o seu desenvolvimento, além da existência de referencial teórico para o respectivo embasamento da investigação.

\subsection{Limitações}

A opção por enfatizar os aspectos objetivos da avaliação de desempenho, particularmente sob a ótica da eficiência produtiva, faz com que algumas características qualitativas das atividades desenvolvidas pelas ILPIs não sejam consideradas diretamente. Se, por um lado, a abordagem quantitativa favorece a adoção de instrumentos capazes de mensurar, comparar e generalizar

resultados entre as próprias organizações, por outro lado não são priorizados os aspectos 
subjetivos e particularizados que dependeriam de outros tipos de ferramentas para o devido tratamento e para uma análise de efetividade.

Os resultados obtidos pela Análise Envoltória de Dados são pertinentes à amostra considerada, conforme as variáveis selecionadas. Tal fato não permite a generalização dos resultados para outras entidades nem regiões, mas fornece dados relevantes para possíveis comparações.

\subsection{Contribuições}

Espera-se que, por meio desta pesquisa, sejam oferecidos elementos avaliativos de eficiência sob a ótica produtiva aos doadores de recursos, aos órgãos governamentais fiscalizadores e aos próprios gestores de organizações filantrópicas, estimulando-se o debate sobre os parâmetros utilizados para se classificar e avaliar as entidades que atuam nesse segmento de reconhecida relevância social.

Outra contribuição é o levantamento do perfil das ILPIs filantrópicas do Estado de São Paulo, dados esses não disponibilizados, até o momento, na literatura brasileira.

Também se busca atender à demanda acadêmica por trabalhos nesta linha de pesquisa e estimular, dessa maneira, novas contribuições pertinentes ao ambiente nacional, considerando as peculiaridades das Organizações do Terceiro Setor.

\subsection{Estruturação do trabalho}

A estruturação do trabalho foi realizada nos capítulos ordenados e descritos a seguir:

Capítulo 1 - Apresenta, delimita e problematiza o assunto tratado, assim como caracteriza e contextualiza o objeto de estudo. Contém a justificativa, as questões de pesquisa, as hipóteses direcionadoras, os objetivos, as limitações do trabalho e as contribuições esperadas. 
Capítulo 2 - Expõe o referencial teórico considerado para o desenvolvimento das ideias centrais do trabalho e reúne os elementos conceituais necessários para a sustentação da análise de dados e respectiva conclusão.

Capítulo 3 - Evidencia a trajetória percorrida para a elaboração da pesquisa, além de destacar os seus aspectos epistêmicos.

Capítulo 4 - Analisa os dados obtidos através da aplicação dos modelos estatísticos utilizados na amostra selecionada, objetivando-se testar as hipóteses adotadas nesta pesquisa.

Capítulo 5 - Sintetiza e conclui o trabalho, respondendo as questões propostas e sugerindo estudos futuros sobre o tema. 


\section{REFERENCIAL TEÓRICO}

A seguir, é apresentado o levantamento bibliográfico que busca oferecer suporte e fundamentação teórica ao estudo.

\section{$2.1 \quad$ Terceiro Setor}

Na literatura científica e em textos destinados ao público em geral, é frequente a utilização da palavra Terceiro Setor como sinônimo de: Sociedade Civil, Setor Não-Governamental, Economia Social, Setor Privado Não-Estatal, Setor Sem Fins Lucrativos, Setor Independente, Setor Caritativo, Setor Voluntário, entre outros (ROSE-ACKERMAN, 1986; WEISBROD, 1988; DRUCKER, 1994; SALAMON, 1995; BRESSER PEREIRA, 1997; FALCONER, 1999; LIGHT, 2002; PAES, 2001; FISCHER, 2002; GLAESER, 2003; HUDSON, 2004). Apesar da popularização do termo, a caracterização e a delimitação desse setor ainda provocam algumas divergências conceituais entre os próprios pesquisadores (REIDER, 2001), sugerindo que se trata de um ambiente em busca de uma definição.

Fernandes (1994) caracteriza o Primeiro Setor (Estado) como aquele formado por agentes públicos com finalidades públicas, o Segundo Setor (Mercado) composto por agentes privados com finalidades privadas e, finalmente, o Terceiro Setor como o ambiente que agrupa os agentes privados com finalidades públicas, conforme observado no Quadro 1.

Quadro 1 - Caracterização dos setores

\begin{tabular}{|c|l|l|}
\hline Setor & Agentes & Fins \\
\hline $1^{\circ}$ Setor (Estado) & Públicos & Públicos \\
\hline $2^{\circ}$ Setor (Mercado) & Privados & Privados \\
\hline $3^{\circ}$ Setor & Privados & Públicos \\
\hline
\end{tabular}

FONTE: FERNANDES, 1994

Corroborando com Fernandes (1994), diversos autores, como Paes (2001) e Fischer (2002), entendem que o Terceiro Setor é o ambiente que reúne as organizações privadas, autônomas e com administração própria, sem fins lucrativos, cuja atuação voluntária é dirigida a finalidades coletivas ou públicas. 
Assumindo-se um panorama trissetorial, em que os respectivos setores são mutuamente excludentes e coletivamente exaustivos, tem-se:

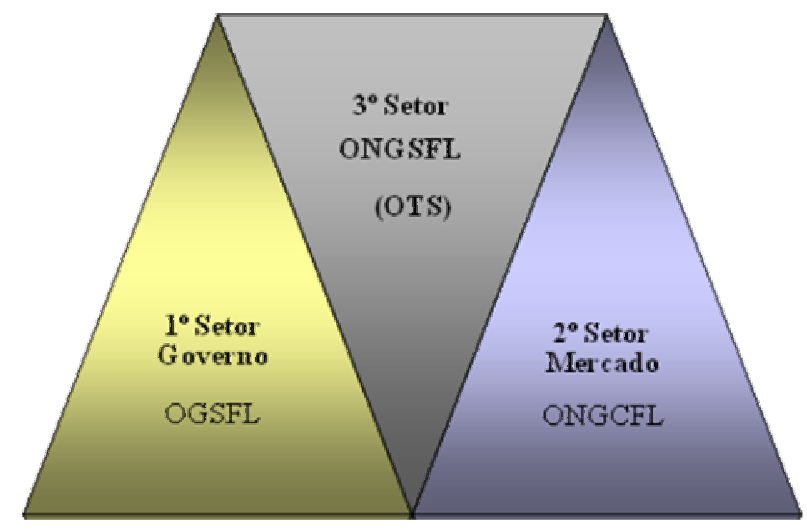

Ilustração 1 - Representação dos setores

$>\quad 1^{\circ}$ Setor: Organizações Governamentais Sem Fins Lucrativos (OGSFL)

$>\quad 2^{\circ}$ Setor: Organizações Não-Governamentais Com Fins Lucrativos (ONGCFL)

$>\quad 3^{\circ}$ Setor: Organizações Não-Governamentais Sem Fins Lucrativos (ONGSFL)

Classificar uma organização, simplesmente, como não-governamental, apenas a caracteriza como sendo uma entidade que não pertence nem é dirigida por órgãos e agências do Estado, ou seja, diferencia-se a organização do $1^{\circ}$ Setor daquelas dos demais setores. As empresas privadas ( $2^{\circ}$ Setor) também não são governamentais.

Servindo-se de mais um critério de classificação, se a entidade possui (ou não) fins lucrativos, diferenciam-se as organizações do $2^{\circ}$ Setor das demais. As entidades do Estado ( $1^{\circ}$ Setor) não têm fins lucrativos.

As organizações do $3^{\circ}$ Setor (OTS), portanto, diferenciam-se do $1^{\circ}$ Setor por não serem governamentais, e se diferenciam do $2^{\circ}$ Setor por não possuírem fins lucrativos. De outra maneira, pode-se afirmar que essas organizações são não-governamentais e sem fins lucrativos (ONGSFL). 
A representação dos setores separados pela natureza de suas organizações, conforme a Ilustração 1, é exclusivamente didática, mas não é a única. Conforme os interesses do pesquisador, podem ser incluídas novas segmentações, contudo o panorama trissetorial é o mais utilizado.

Frumkin (2002) identifica quatro funções principais desse setor:

- Promoção do compromisso político e cívico;

- $\quad$ Prestação de serviços essenciais;

- Oferecimento de um ambiente para o empreendedorismo social;

- $\quad$ Expressão de crenças e valores.

Além da importância política e social, o Terceiro Setor possui uma participação econômica significativa. Conforme Salamon et al. (1999), o setor emprega 19 milhões de trabalhadores remunerados em horário integral e movimenta quantias superiores ao Produto Interno Bruto de vários países. Flynn e Hodgkinson (2001) estimam essa movimentação em US\$ 1,6 trilhão.

O Primeiro Setor (Estado) vem sendo objeto de amplas discussões acadêmicas e também em fóruns sociais sobre as responsabilidades inerentes às suas funções visando ao bem-estar coletivo. Problemas relacionados com o fracasso das políticas e ações públicas diante das crescentes demandas sociais são levantados pela Government Failure Theory, cuja ideia central é citada por autores como Rose-Ackerman (1986), Weisbrod (1988), Herlinzer e Nitterhouse (1994), Shim e Siegel (1997), sugerindo uma justificativa para o aparecimento das organizações sem fins lucrativos, em que elas surgem como uma resposta da sociedade civil à ineficiência e ineficácia governamental.

Pesquisadores sobre o papel do Estado e sua relação com a sociedade, como Bresser Pereira (2000, 2001), argumentam que a expansão do Terceiro Setor é uma consequência da maior adequação e eficiência das organizações não governamentais e organizações sem fins lucrativos que prestam serviços sociais que não são naturalmente monopolistas. No entanto, presume-se a existência de mecanismos de controle social por essas organizações da sociedade civil, de modo a garantir que os serviços podem ser eficientes e eficazes. 
Falconer (1999) sugeriu que o crescimento do Terceiro Setor poderia estar vinculado a medidas intencionais de Governos que buscariam reduzir a participação estatal nas ações sociais diretas e, para tanto, incentivariam a entrada e o comprometimento de organizações sem fins lucrativos nas ações públicas. Nesse sentido, a Government Failure Theory assumiria novos contornos, pois o estímulo para o aumento da participação da sociedade civil em ações públicas não seria gerado, unicamente, pela ineficácia do Estado no cumprimento das políticas públicas, mas porque os governantes também desejariam contar com organizações civis atuando como agentes de sua política social.

Salamon (1995), entretanto, ao analisar o caso americano na década de 80 e início dos anos 90, verificou que a expansão do Terceiro Setor ocorreu diante da expansão do próprio Estado. Assim, o aumento da participação de ações da sociedade civil em busca de soluções privadas para problemas públicos, acompanhou um período de rápido crescimento do Estado americano. O desenvolvimento de políticas públicas voltadas ao bem-estar, aliado ao crescimento das doações privadas, alimentou as próprias organizações americanas sem fins lucrativos, que passaram a ter maior participação na política governamental (SALAMON, 1995; SALAMON; TOEPLER, 2000).

Sob uma perspectiva complementar, a chamada Market Failure Theory sugere que o desinteresse das empresas de mercado para atender uma demanda por produtos sociais, faz com que as organizações do Terceiro Setor sejam estimuladas a oferecer bens e serviços de interesse da coletividade (HANSMANN, 1986). Assim, os produtos gerados pelos agentes da sociedade civil contribuiriam para reduzir falhas de mercado no atendimento de produtos de interesse social, mas não despertaram o interesse econômico das empresas.

Fischer (2002) e Junqueira (2004) destacam a relevância do estabelecimento de alianças e parcerias intersetoriais e a formação de redes sociais objetivando a promoção de ações de interesses coletivos. Sob essa perspectiva, a sociedade civil exerceria o direito democrático de manifestação de seus interesses sociais e contribuiria para a consecução de políticas públicas sob a gestão estatal. 


\subsection{Caracterização das Organizações do Terceiro Setor}

Dentre os autores que procuram caracterizar as OTS, ao invés da simples negação de suas finalidades não lucrativas e da natureza não governamental como parâmetro, Herzlinger e Nitterhouse (1994, p. 2) destacam "a contribuição prestada à sociedade por estas entidades para a promoção do bem comum", pois preferem uma posição mais afirmativa à simples ausência da motivação pelo lucro. Mas as abordagens genéricas também podem não permitir uma caracterização objetiva das OTS.

Drucker (1994, p. xiv), por exemplo, considera que as OTS são agentes de mudanças humanas, em que "[...] o seu produto é um paciente curado, uma criança que aprende, um jovem que se transforma em um adulto com respeito próprio; isto é, toda uma vida transformada." Dessa maneira, o propósito maior dessas entidades seria o auxílio e o aprimoramento dos indivíduos e, consequentemente, da coletividade. Essas características apontadas por Drucker não são exclusivas das OTS, pois organizações governamentais ou mesmo privadas com fins lucrativos também podem promover tais mudanças humanas, como um hospital do sistema público de saúde ou um hospital particular, ou uma escola pública ou privada. Além disso, nem sempre o produto das OTS pode ser, unanimemente, considerado um benefício social, pois podem ocorrer situações antagônicas entre OTS criadas para defender interesses de grupos divergentes quanto às propostas públicas, como associações pró ou contra a legalização de drogas, do aborto etc. Apesar das OTS permitirem a expressão de segmentos da sociedade num ambiente democrático, nem sempre se poderá afirmar que o produto final será um paciente curado etc.

Abordagens mais específicas contribuem para a caracterização objetiva das OTS. Wolf (1999) afirma que uma diferença essencial entre as OTS e as demais entidades situa-se na concepção de propriedade. Não há proprietários de OTS, pois essas têm caráter público.

Shim e Siegel (1997, p.2) as definem como entidades que são financiadas, ao menos parcialmente, pela própria sociedade através de isenção tributária, e são:

[...] aquelas que fornecem serviços desejados pela sociedade sem a intenção de lucro, não possuindo ações ou quotas que possam ser negociadas, além de reinvestirem integralmente eventuais superávits. Desta maneira, não deve haver a distribuição dos resultados a qualquer de seus membros ou colaboradores. 
O Conselho Federal de Contabilidade - CFC, através da Norma Brasileira de Contabilidade Técnica (NBC-T) $n^{\circ}$. 10.19.1.3, define que as entidades sem finalidade de lucro "[...] são aquelas em que o resultado positivo não é destinado aos detentores do patrimônio líquido e o lucro e o prejuízo são denominados, respectivamente, de superávit e déficit." A definição do CFC deveria ser revista, pois menciona a existência de detentores do patrimônio líquido, mas não existe a figura do proprietário ou acionista em OTS.

Glaeser (2003) considera os privilégios fiscais uma das maiores características dessas entidades. Porém, os recursos públicos podem não ser suficientes para a manutenção e desenvolvimento de suas atividades, obrigando-as à busca de outras fontes de recursos, permitindo a continuidade das organizações.

Salamon et al. (1999) acrescentam a autonomia diretiva que essas entidades devem possuir (self-governing), destacando a necessidade da existência formal através de estrutura e presença institucionais. Os autores, ainda, reforçam a possibilidade de recebimento de doações não somente em dinheiro, mas também de tempo e serviços, através do voluntariado. Apesar da grande diversidade e diferenças de porte, objetivos específicos, recursos econômicos etc., as seguintes características são comuns nessas organizações (MILANI FILHO, 2004):

- $\quad$ Não há proprietários formais;

- São organizações não-governamentais dotadas de autonomia diretiva;

- Suprem parcialmente o papel do Estado no atendimento a determinadas necessidades sociais;

- $\quad$ Possuem estrutura e presença institucionais;

- $\quad$ São constituídas pelo interesse social, portanto visam proporcionar benefícios sociais;

- $\quad$ São unidades econômicas;

- Precisam obter recursos para a própria sobrevivência e manutenção das atividades (esses recursos podem ser públicos e/ou privados);

- Não deve haver qualquer distribuição de resultados aos seus membros ou colaboradores, reinvestindo os superávits obtidos;

- $\quad$ Podem gozar de privilégios fiscais, conforme a legislação vigente. 
Salamon (1995) considerou três dimensões como sendo cruciais, ressaltando os seguintes contrastes:

a) OTS focadas no oferecimento de produtos e/ou serviços ou OTS atuando como simples distribuidoras de fundos a outras entidades;

b) OTS focadas no oferecimento de produtos e/ou serviços aos próprios membros associados ou OTS voltadas ao público em geral;

c) OTS focadas no oferecimento de serviços sacramentais e religiosos ou OTS que não ofereçam serviços de natureza religiosa.

\subsubsection{Aspectos históricos}

A sociedade civil brasileira teve suas bases estabelecidas durante o processo de colonização por Portugal no início do século XVI. As primeiras organizações não-governamentais sem fins lucrativos do Brasil foram as Santas Casas de Misericórdia, que eram entidades beneficentes mantidas pela Igreja Católica, a qual contava com o apoio da Coroa portuguesa para a prestação de serviços de saúde à população carente (LANDIM, 1997). A Santa Casa de Santos, fundada por Braz Cubas em 1543, foi a primeira dessas instituições.

As organizações de assistência social e saúde pertenciam a um restrito grupo autorizado pelo Governo Português a trabalhar com a população, uma vez que colaboravam com os interesses de Portugal para lidar com as demandas sociais. As entidades assistenciais com vínculos religiosos continuaram a contribuir com as políticas sociais mesmo após a independência, com o advento da Monarquia brasileira (1822-1889), no subsequente período republicano e prossegue até os nossos dias (ANDION; SERVA, 2004).

$\mathrm{Na}$ história brasileira, os primeiros movimentos sociais organizados surgiram com maior ênfase a partir do início do século XX, com a industrialização e o crescimento da população urbana. Esses movimentos foram influenciados por ideologias esquerdistas como o marxismo e anarquismo, relacionados às questões trabalhistas e políticas, mas ainda não se expressavam, em sua maioria, através de organizações independentes e oficiais (AMARAL, 2007). Tais mobilizações, como a greve geral em São Paulo, em 1917, representavam o desacordo de grupos urbanos com a situação política e social vigente na época (DIAS, 1977). Mais tarde, durante o governo autoritário e populista de Getúlio Vargas (1930-1945), o movimento 
trabalhista foi organizado sob regulamentação estatal, assim como o sindicalismo ganhou expressão no cenário nacional (ANDION; SERVA, 2004). Apesar do fortalecimento do movimento trabalhista, a sociedade civil baseou-se mais sobre a busca do bem-estar do que sobre instituições políticas.

Em meados da década de 40, foram criadas instituições que intermediavam o interesse estatal com atuação direta na sociedade e que atendiam a interesses considerados estratégicos, como, por exemplo, o Serviço Social da Indústria (SESI), o Serviço Nacional de Aprendizagem Industrial (SENAI), o Serviço Nacional de Aprendizagem Comercial (SENAC), Serviço Social do Comércio (SESC) e a Legião Brasileira de Assistência (LBA).

Entre 1964 e 1985, durante o governo militar, organizações da sociedade civil que não correspondiam aos interesses estatais foram consideradas ilegais e proibidas de operar (TELLES, 1987). A livre manifestação de caráter político era restrita. Os sindicatos continuaram a existir, mas sob intensa vigilância de suas atividades.

Desde 1986, considerando-se a democratização política e com a nova Constituição brasileira promulgada em 1988, a sociedade civil assistiu ao aparecimento de várias organizações de direitos civis e de proteção de interesses de minorias desfavorecidas (índios, mulheres, afrodescendentes etc.). Assume-se que os anos 80 representaram um marco histórico para o Terceiro Setor brasileiro.

Atualmente, existem cerca de 338 mil entidades não governamentais sem fins lucrativos no Brasil (IBGE, 2005). Mesmo com uma tendência de crescimento e desenvolvimento das atividades relacionadas aos direitos civis, em contraste com as práticas de assistência social, as organizações do Terceiro Setor ainda estimulam debates na comunidade acadêmica e na sociedade em geral que questionam se elas estão complementando o Estado na formulação e implementação de políticas públicas ou se estão substituindo o Estado no atendimento das demandas sociais que são de responsabilidade estatal (FERNANDES, 1994; FALCONER, 1999). 


\subsubsection{Principais núcleos de pesquisas acadêmicas sobre o Terceiro Setor}

A criação e a rápida expansão de cursos destinados à profissionalização de gestores de OTS, particularmente na América do Norte (O’NEILL; FLETCHER, 1998), incentivam as pesquisas acadêmicas nessa linha, mas ainda se encontram em fase inicial de desenvolvimento. Praticamente todas as grandes universidades americanas e canadenses possuem linhas de pesquisa e centros de estudos voltados às entidades sem fins lucrativos. Conforme o vínculo institucional dos pesquisadores identificados na literatura consultada sobre o Terceiro Setor, destacam-se os seguintes centros de pesquisas:

- $\quad$ Center for Civil Society Studies - The Johns Hopkins University;

- $\quad$ Center for Democracy and Third Sector - Georgetown University;

- $\quad$ Center for Philanthropy and Community Service - University of Texas;

- $\quad$ Centre for Public Sector Studies - University of Victoria;

- $\quad$ Center for the Study of Philanthropy and Voluntarism - Duke University;

- $\quad$ Centre for Voluntary Sector Research and Development - Carleton University;

- $\quad$ The Center on Philanthropy - University of Indiana;

- $\quad$ The Centre for Voluntary Sector Studies - Ryerson University;

- $\quad$ The Hauser Center for Nonprofit Organizations - Harvard University.

No Brasil, despontam alguns núcleos de pesquisa voltados ao Terceiro Setor e que apresentam um significativo volume de produção, como por exemplo:

- $\quad$ Centro de Estudos do Terceiro Setor - CETS/FGV;

- $\quad$ Centro de Estudos em Administração do Terceiro Setor - CEATS/USP;

- $\quad$ Centro de Tecnologia e Gestão do Terceiro Setor do SENAC-SP;

- $\quad$ Núcleo de Estudos Avançados do Terceiro Setor - NEATS/PUC-SP;

- $\quad$ Núcleo de Estudos do Terceiro Setor - NETS/Universidade Mackenzie.

\subsubsection{Certificado de Entidade Beneficente de Assistência Social - CEBAS}

O Certificado de Entidade Beneficente de Assistência Social - CEBAS é o reconhecimento oficial das entidades que se caracterizam por seu caráter filantrópico. A concessão ou renovação do CEBAS (correspondente ao antigo Certificado de Filantropia) está referida no inciso IV do artigo 18 da Lei 8.742 de 7/12/93, obedecendo ao disposto no Decreto 2.536 de 
6/04/98, modificado pelo Decreto 3.504, de 13/06/00, e regulado pela Resolução CNAS no 177 de 10/08/00. As condições para a sua obtenção estão descritas nessa Lei.

O CEBAS poderá ser requerido apenas pelas entidades que tenham uma das seguintes finalidades:

- $\quad$ Proteção à família, maternidade, infância, adolescência e velhice;

- $\quad$ Amparo a crianças e adolescentes;

- $\quad$ Ações relativas a pessoas portadoras de deficiências;

- $\quad$ Assistência social ou saúde;

- $\quad$ Integração de pessoas ao mercado de trabalho;

- $\quad$ Defesa dos beneficiários da Lei Orgânica de Assistência Social.

A Medida Provisória 446, publicada no Diário Oficial da União em 10/11/08, estabeleceu as atuais regras para certificação das entidades beneficentes de assistência social, em que a análise e o julgamento dos processos de concessão e renovação do CEBAS foram descentralizados. Anteriormente, o Conselho Nacional de Assistência Social (CNAS) analisava todos os processos e o ministro da Previdência julgava os recursos. Com a descentralização, o CNAS ficou apenas com a responsabilidade de elaborar políticas para a área de assistência social e os ministérios da Educação (MEC), Saúde (MS) e Desenvolvimento Social (MDS) ficaram incumbidos da análise dos pedidos de certificação e renovação. Cada ministério pode adotar critérios específicos para o exame dos pedidos de certificação, conforme as peculiaridades de suas áreas de atuação.

Sob essa segmentação, o MDS, por exemplo, encarrega-se da análise dos processos das entidades de assistência social, o MEC responsabiliza-se pelos pedidos de certificação das universidades e o MS dos hospitais. Cada órgão também tem a autonomia de definir o prazo de validade dos certificados filantrópicos concedidos, podendo variar de um a três anos. Até dezembro de 2008, a validade era, uniformemente, de três anos.

Todas as entidades certificadas estão isentas do pagamento da cota patronal ao Instituto Nacional do Seguro Social (INSS), da Contribuição sobre o Lucro Líquido (CSL), do Programa de Integração Social (PIS) e, também, da Contribuição Financeira Social (COFINS). 


\subsubsection{Compromisso social}

Light (2002), ao investigar os fatores que contribuiriam para que as OTS alcançassem seus objetivos, relatou que a maioria dos 500 profissionais e pesquisadores que participaram de sua pesquisa afirmou que as entidades devem priorizar a entrada de recursos para que seja possível cumprir a missão e sobreviver. Assim, as duas maiores preocupações dos gestores das OTS são: atingir os objetivos estabelecidos através da utilização eficiente e eficaz de recursos e, também, obter esses recursos para a continuidade operacional.

Essa dependência por recursos permite o questionamento sobre até que ponto a necessidade de captação de recursos poderia comprometer ou desviar a própria missão social da organização para concentrar os esforços operacionais nas atividades que proporcionam receitas (FRUMKIN, 2002, p. 172). A geração de renda própria através da comercialização de produtos e serviços, além da captação de recursos públicos e privados, tais como subvenções e doações, deveriam ser vistos como atividades necessárias, mas não como as principais das OTS.

Um ambiente competitivo por doações e transferências estatais poderia contribuir para que grandes doadores influenciassem o processo decisório das OTS mais dependentes, chegando a influenciar, até mesmo, as decisões estratégicas (GLAESER, 2003). A dependência por recursos poderia, desse modo, causar uma submissão da entidade, em diferentes graus, ante o direcionamento da aplicação dos recursos recebidos, novamente levantando a questão da coerência da missão.

Glaeser (2003) também alerta que a transparência e a prestação de contas tornaram-se elementos essenciais para contribuir com a própria sobrevivência das entidades, uma vez que estão inseridas num ambiente competitivo por recursos financeiros e não-financeiros e aquelas que melhor atenderem às necessidades dos doadores por informações terão maior probabilidade de captação desses recursos.

Na posição de stakeholders, é opção dos doadores o direcionamento de recursos àquelas organizações nas quais depositarão sua confiança e que, supostamente, corresponderão às suas 
expectativas. Nesse sentido, pode ser um fator relevante para essa escolha a quantidade e a qualidade das informações que obterá sobre a OTS objetivando a sua tomada de decisão.

Enquanto o desafio das OTS, levantado por Light (2002), é cumprir a missão e sobreviver, o desafio dos doadores é escolher a entidade que deverá atender às suas expectativas e maximizar os seus interesses. Uma indagação que se pode fazer é se os fornecedores de fundos para uma organização ineficiente, racionalmente, continuariam a doar recursos diante de alternativas mais eficientes.

\subsubsection{Entidades filantrópicas no Brasil}

Conforme o Ministério do Desenvolvimento Social - MDS (2009), existem registradas 6.942 entidades filantrópicas no Brasil detentoras do CEBAS que atuam nas áreas de assistência social, saúde e educação.

No Gráfico 1, verifica-se a participação dos Estados com maior representatividade nesse total, destacando-se São Paulo com 33,3\% da quantidade total das entidades, seguido por Minas Gerais (17,2\%). Ambos abrigam mais da metade de todas as organizações filantrópicas nacionais, acumulando 50,5\% delas. Os Estados do Paraná, Rio Grande do Sul e Rio de Janeiro reúnem $25,7 \%$ das organizações. Os demais $23,9 \%$ das entidades encontram-se distribuídos pelas demais unidades federativas.

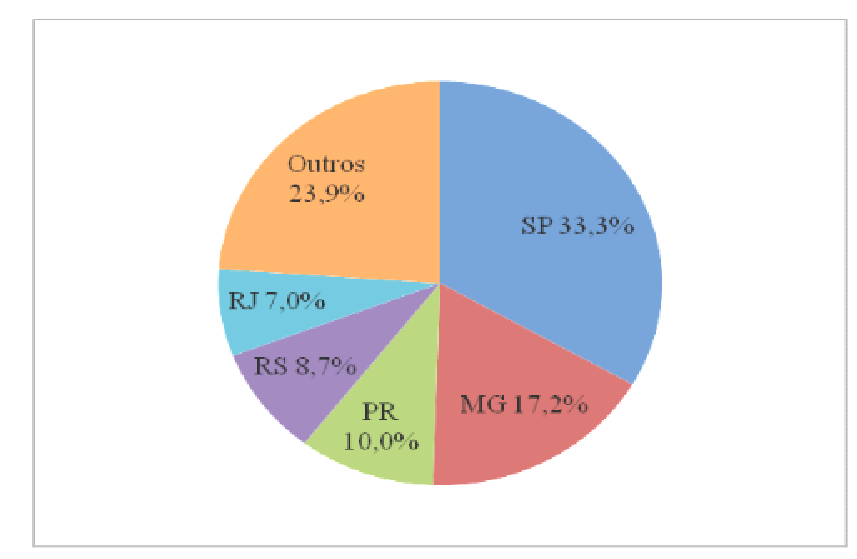

Gráfico 1 - Distribuição das entidades filantrópicas por Estado FONTE: MDS (2009) 
Na Tabela 1, relaciona-se a quantidade de organizações filantrópicas com a população de cada Estado. O Paraná apresenta a menor relação, com 15,1 mil habitantes por entidade (hab/ent), seguido por Minas Gerais (16,3 mil hab/ent), Santa Catarina (16,8 mil hab/ent) e São Paulo (17,8 mil hab/ent). A média nacional é de 27,0 mil hab/ent.

Tabela 1 - Quantidade de habitantes por entidade filan
\begin{tabular}{|ccrc|}
\hline UF & hab (milhões) & $\mathrm{n}^{0}$ entidades & hab/ent \\
\hline $\mathrm{PR}$ & 10,5 & 691 & 15,1 \\
$\mathrm{MG}$ & 19,5 & 1.193 & 16,3 \\
$\mathrm{SC}$ & 6,0 & 355 & 16,8 \\
$\mathrm{SP}$ & 41,2 & 2.314 & 17,8 \\
Outros & 110,0 & 2.389 & 46,1 \\
\hline Total & 187,2 & 6.942 & 27,0 \\
\hline
\end{tabular}

\subsubsection{Voluntariado}

A doação espontânea de tempo, esforço, conhecimento e dedicação de alguém para a realização de determinado trabalho marca a atuação voluntária. Atrair, treinar, motivar, administrar e manter voluntários são tarefas que desafiam qualquer gestor.

Hudson (2004), ao se referir às organizações do Terceiro Setor americano, observa que o voluntariado é um componente essencial para tais entidades, constituindo-se em força de trabalho que sustenta e revitaliza as atividades sociais.

No Brasil, a pesquisa realizada pelo Instituto Ipsos-Marplan, entre janeiro e dezembro de 2004, entrevistando-se 50.520 pessoas em nove centros urbanos (São Paulo, Rio de Janeiro, Curitiba, Porto Alegre, Belo Horizonte, Brasília, Salvador, Recife e Fortaleza), apontou que cerca de $9 \%$ da população presta algum tipo de serviço voluntário. Destes, 53\% são mulheres e 47\% são homens (IPSOS-MARPLAN, 2004). Conforme o Gráfico 2, verifica-se a maior participação das pessoas em faixas etárias elevadas. 


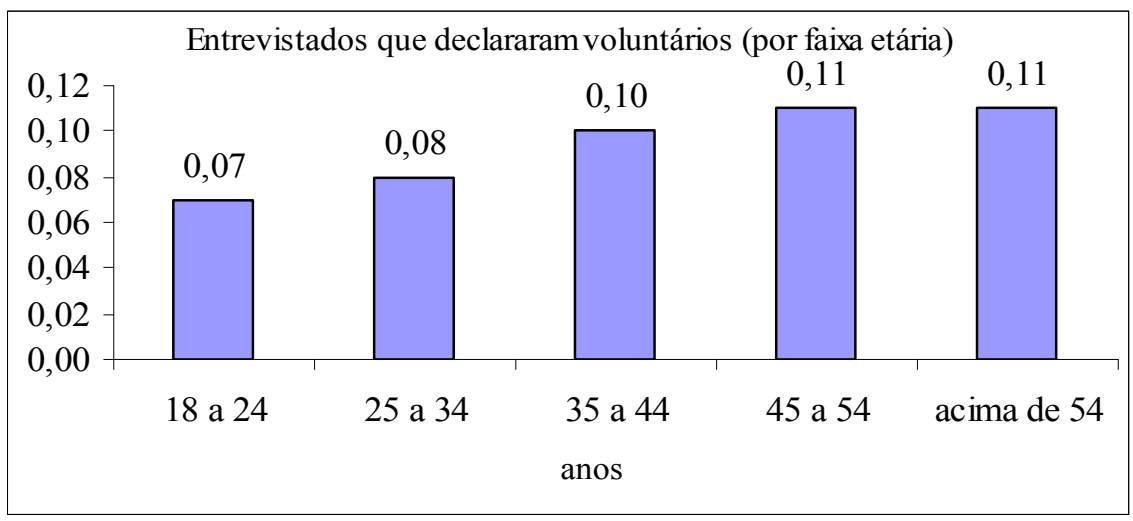

Gráfico 2 - Entrevistados que se declaram voluntários (por faixa etária) FONTE: IPSOS-MARPLAN (2004)

Para Handy (1990), genericamente existem três grandes tipos de bases contratuais entre qualquer organização e seus integrantes:

- Coercitiva, baseada na autoridade e/ou na força (exemplo: forças armadas, penitenciárias);

- Calculista, na qual se espera receber determinada remuneração ou benefícios como troca pela atividade desenvolvida (com o trabalhador assalariado em qualquer tipo de entidade lucrativa ou não);

- Cooperativa, baseada na liberdade de escolha em doar seu tempo e esforço, sem expectativa de remuneração ou privilégios (como o trabalhador voluntário).

O trabalho voluntário requer motivações pessoais em torno de uma causa comum e não tem caráter obrigatório.

Sob o aspecto normativo, a Lei $\mathrm{n}^{\circ}$ 9.608, de 18 de fevereiro de 1998, dispõe sobre o serviço voluntário e o considera uma atividade não remunerada, prestada por pessoa física à entidade pública de qualquer natureza ou instituição privada de fins não lucrativos, que tenha objetivos cívicos, culturais, educacionais, científicos, recreativos ou de assistência social, inclusive, mutualidade. Para regular essa relação, as entidades deverão celebrar um termo de adesão, devendo constar o objeto e as condições do seu exercício. Essa lei também visa preservar de ações trabalhistas tanto o voluntário como a entidade que o recebe, conforme expresso em seu Artigo $1^{\circ}$ - Parágrafo único - "O serviço voluntário não gera vínculo empregatício nem obrigação de natureza trabalhista, previdenciária ou afim." 
No Gráfico 3, verifica-se que, quanto maior o grau de instrução, maior é a atuação dos indivíduos no trabalho voluntário, destacando-se aqueles que se encontram em nível de pósgraduação, em que 23\% dos entrevistados declararam-se voluntários em alguma atividade. Aqueles que apresentam um grau de instrução menor, por sua vez, declararam não participar de atividades voluntárias.

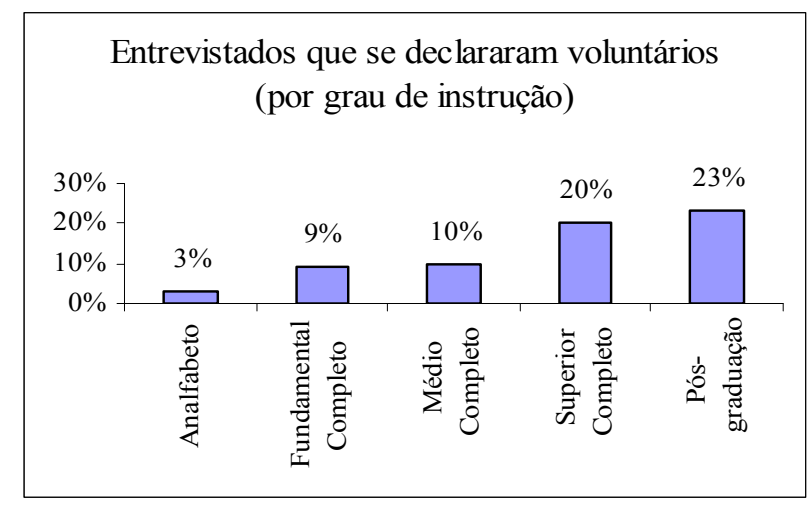

Gráfico 3 - Entrevistados que se declaram voluntários (por grau de instrução) FONTE: Ipsos-Marplan (2004)

\subsubsection{Teoria Institucional, legitimidade e isomorfismo}

Tolbert e Zucker (1999) registram que a teoria institucional teve início nas análises organizacionais sob a ótica sociológica nos anos 40, mas estruturou-se a partir de Selznick (1957) e, posteriormente, por influência de autores como Meyer e Rowan (1977), Dimaggio e Powell $(1983,1991)$ e Scott $(1995)$. Os preceitos básicos dessa teoria relacionam-se à incorporação, pelas organizações, de práticas e procedimentos lastreados em conceitos e valores institucionalizados na coletividade, objetivando-se a própria sobrevivência. Evidencia-se a relevância do contexto e da adoção de determinados comportamentos em ambientes de incertezas.

A sobrevivência das organizações, sob a perspectiva institucional, depende da sua capacidade de adaptação às diversas pressões ambientais. Perrow (1986) aponta a legitimidade e o isomorfismo como os principais fatores para a continuidade corporativa.

Para Meyer e Rowan (1977), a legitimidade é obtida pela organização através da adoção de práticas que caracterizem o cumprimento das regras estabelecidas em determinado contexto, proporcionando o reconhecimento institucional. Nesse sentido, pressupõe-se que as entidades 
adaptem suas estruturas e ações para a conformidade legal influenciadas por pressões normativas advindas do poder público e de outros órgãos reguladores.

O isomorfismo é caracterizado pela reprodução de procedimentos já adotados por outras entidades. Dimaggio e Powell (1983) observam que a busca por legitimidade faz com que as organizações, num mesmo contexto político, econômico e social e, portanto, sob as mesmas pressões ambientais, passem a adotar estratégias semelhantes para a conformidade legal e para o atendimento das expectativas de grupos de pressão. A adoção de práticas semelhantes objetivando a legitimidade caracteriza o isomorfismo institucional (DIMAGGIO; POWELL, 1983, SLACK; HININGS, 1994).

Dimaggio e Powell (1983) identificaram, ainda, o isomorfismo competitivo, decorrente das pressões de mercado exercidas sobre as organizações, com base nas relações econômicas estabelecidas entre os agentes num ambiente de concorrência. Diante do sucesso de empresas rivais, os gestores podem mimetizar estratégias de atuação objetivando alcançar os mesmos resultados.

As vantagens oferecidas pelo comportamento isomórfico, segundo a Teoria Institucional, repousam sobre o estabelecimento de condições similares que favorecem as transações entre os agentes e promovem, também, a incorporação de valores e normas já compartilhadas socialmente. Dessa maneira, ao expor publicamente que adota regras aceitas pela coletividade, a entidade estimula o reconhecimento e a aceitação externa de suas práticas, facilitando a captação de recursos, a sobrevivência e uma possível expansão (MEYER; ROWAN, 1977).

As constantes pressões ambientais incentivam a conformidade com os padrões estabelecidos e, em decorrência, provocam a homogeneização das estruturas organizacionais e de práticas de sucesso implementadas por outras entidades. Uma crítica sobre o comportamento isomórfico, entretanto, é encontrada na própria literatura da teoria institucional. Autores como Meyer e Rowan (1977), Tolbert e Zucker (1999), Kostova et al. (2008), entre outros, apontam que a incorporação de práticas e procedimentos socialmente aceitos não significa, necessariamente, que seja a escolha que acarretará a maximização dos resultados ou que atingirá os objetivos estratégicos da organização. A adoção de práticas geralmente aceitas em um ambiente de incertezas pode não ser justificada se baseada em modelos decisórios 
tradicionais que levam em consideração as relações de custo-benefício sob a ótica racional, ou seja, a adoção de certas práticas e procedimentos é baseada no comportamento isomórfico da organização sem a efetiva compreensão dos benefícios gerados para o desempenho, além da expectativa de que essa postura contribuirá para a legitimidade e sobrevivência organizacional.

Segundo Scott (1995), o ambiente institucional, através de regras e procedimentos estabelecidos, faz com que as organizações conformem as suas estruturas às respectivas pressões e controles sociais e, dessa maneira, caracteriza-se o isomorfismo institucional, o qual é típico de entidades como igrejas, escolas e hospitais públicos, órgãos governamentais etc. Sob essa mesma perspectiva, pode-se estender a busca por legitimidade a todas as organizações do Terceiro Setor que, de forma geral, procuram adaptar-se às exigências legais e às expectativas de seus diferentes stakeholders para o cumprimento de suas missões específicas e para a própria sobrevivência em um ambiente institucionalizado.

A legitimidade e a credibilidade pública propiciam condições para que uma organização filantrópica, por exemplo, capte recursos da comunidade baseando-se em conceitos e valores institucionalizados. Considerando-se que a captação de recursos pode ocorrer num ambiente competitivo, pois organizações similares desejam os mesmos recursos escassos, as práticas de sucesso adotadas por outras organizações competidoras podem ser mimetizadas. A divulgação (ou a omissão) dos mesmos conjuntos informacionais, voltados para a prestação de contas (accountability) e para a evidenciação financeira (disclosure), relaciona-se com o comportamento isomórfico entre as organizações sob a ótica institucional.

\subsubsection{Aspectos contábeis das entidades filantrópicas}

Olak (1996) destaca a utilização do sistema de Contabilidade por Fundos como medida adequada para a evidenciação contábil de OTS.

Conforme Hendriksen e Van Breda (1999), os teóricos da Contabilidade procuram responder questionamentos sob os aspectos normativos e positivos, descobrindo, assim, a melhor maneira de registrar contabilmente uma transação e como os administradores e demais partes interessadas podem conhecer os elementos necessários para a adequada tomada de decisão. Nesse sentido, muitos esforços têm sido feitos para que as entidades sem fins lucrativos 
espelhem sua real situação do ponto de vista econômico-financeiro e atendam aos critérios de transparência desejados, porém o caráter normativo pode condicionar os gestores destas organizações a limitarem seus próprios instrumentos de gestão (IUDÍCIBUS, 2000).

O lucro, ao contrário das entidades do Segundo Setor, não é uma medida claramente relacionada ao desempenho de organizações filantrópicas, uma vez que o cumprimento da respectiva missão liga-se a fatores sociais e não financeiros. Obviamente, qualquer entidade, seja ela filantrópica ou não, deve buscar apresentar resultados financeiros positivos sob o risco de descontinuidade operacional, mas não é o dimensionamento desse resultado que caracterizará o sucesso ou o fracasso das organizações filantrópicas. Nesse sentido, métricas como o resultado econômico, conforme explorado por Slomski (1996), apresentam maior conformidade com parâmetros avaliativos e comparativos das próprias entidades. A mensuração e a divulgação do resultado econômico podem ser tomadas como componentes de transparência.

Como observa Martin (2002), o modelo utilizado para compreender a realidade e para tomar decisões somente será válido se oferecer as informações necessárias e suficientes às partes interessadas, e nada mais perigoso para um tomador de decisões do que trabalhar com um modelo imperfeito. Este é o cuidado que qualquer entidade deve ter para não prejudicar a avaliação de seu desempenho e o planejamento de suas atividades.

Os relatórios contábeis obrigatórios, portanto, contêm informações relevantes, ainda que não sejam suficientes para a análise das entidades do Terceiro Setor. As informações financeiras padronizadas, dessa maneira, devem ser consideradas nos modelos avaliativos dos usuários externos, mas cabe aos pesquisadores da Contabilidade desenvolver esforços para que as entidades sem fins lucrativos espelhem sua real situação do ponto de vista econômico e social, para atender aos critérios de transparência desejados. Entretanto, o caráter normativo pode condicionar os gestores dessas organizações a limitarem seus próprios instrumentos de gestão aos relatórios obrigatórios.

Considerando que as tradicionais peças contábeis fazem parte das exigências legais no processo de renovação do CEBAS, naturalmente as entidades empenham-se em atender os critérios normativos no formato definido. Além dos relatórios de atividades comprovando 
estar desenvolvendo plenamente seus objetivos estatutários, a entidade deverá apresentar, referente ao último triênio:

- Balanços patrimoniais;

- Demonstrativos do resultado;

- Demonstração de mutação do patrimônio;

- Demonstração das origens e aplicações de recursos;

- Notas explicativas evidenciando o resumo das principais práticas contábeis e os critérios de apuração do total das receitas, das despesas, das gratuidades, público-alvo beneficiado com atendimento gratuito, doações, aplicações de recursos, bem como da mensuração das despesas relacionadas com a atividade assistencial.

A entidade, ainda, deverá demonstrar que aplica em bases anuais valores em gratuidade de, no mínimo, $20 \%$ da receita bruta proveniente da venda de serviços, acrescida da receita decorrente de aplicações financeiras, de locação de bens, de venda de bens não integrantes do ativo imobilizado e de doações particulares, cujo montante nunca será inferior à isenção de contribuições sociais usufruídas.

O CNAS somente apreciará as demonstrações contábeis e financeiras que tiverem sido devidamente auditadas por auditor independente legalmente habilitado nos Conselhos Regionais de Contabilidade.

A Resolução do CNAS nº 66, de 16 de abril de 2003, dispõe sobre os critérios de análise das demonstrações contábeis apresentadas pelas entidades filantrópicas ressaltando a completa responsabilidade do Conselho Federal de Contabilidade nessa regulamentação, através suas próprias resoluções, seguindo especialmente os Princípios Fundamentais de Contabilidade e as Normas Brasileiras de Contabilidade.

\subsubsection{Convergência contábil}

O processo de convergência das normas contábeis brasileiras com as normas internacionais (International Financial Reporting Standards - IFRS) emitidas pelo International Accounting Standard Board (IASB) foi marcado pela promulgação da Lei $n^{0} 11.638 / 07$, a qual se direciona, predominantemente, às companhias abertas, mas que apresenta relevantes 
modificações que podem ser adotadas para a apresentação dos relatórios financeiros por todos os tipos de organizações, inclusive aquelas sem finalidade lucrativa.

Em 2005, foi criado o Comitê de Pronunciamentos Contábeis (CPC) com o objetivo de tornar-se o órgão emissor de normas contábeis no Brasil. Em sua origem, o CPC contou com o apoio das seguintes entidades: Conselho Federal de Contabilidade, Associação Brasileira das Empresas de Capital Aberto, Bolsa de Valores de São Paulo, Instituto dos Auditores Independentes do Brasil, Associação dos Analistas de Investimento do Mercado de Capitais e Fundação Instituto de Pesquisas Contábeis, Atuariais e Financeiras (ERNEST \& YOUNG; FIPECAFI, 2009).

Conforme o cronograma de atividades do IASB, estão previstas discussões iniciais sobre a aplicação das IFRS às entidades sem fins lucrativos a partir do ano de 2010, para posterior elaboração de discussion papers e exposure drafts (IASB, 2009). O CPC não se pronunciou sobre normas específicas às OTS, portanto ainda não houve alterações da legislação pertinente.

\section{$2.3 \quad$ Idosos}

Segundo a Organização Mundial da Saúde (OMS, 1987), é considerado idoso o indivíduo com idade igual ou superior a 60 anos, independente do contexto regional, social e econômico em que a pessoa se encontre.

Seguindo o mesmo parâmetro adotado pela OMS, a legislação brasileira considera idoso todo o indivíduo com idade igual ou superior a 60 anos, conforme encontrado no Estatuto do Idoso - Lei 10.741/2003 (Anexo A).

Esse marco estabelecido, entretanto, não representa um ponto preciso para que as mudanças relacionadas ao envelhecimento se manifestem, pois há diferenças significativas, entre indivíduos com a mesma idade cronológica, de natureza social e biopsíquica, além de variações nos níveis de autonomia. Aspectos relacionados ao gênero, tempo de estudo e renda costumam ser expressivos na diferenciação das condições dos indivíduos (VERAS et al., 
2008). Para Araújo e Alves (2000), é comum se relacionar o fenômeno do envelhecimento com o afastamento do mercado de trabalho pela aposentadoria.

A Europa é a região que concentra os países com população superior a 10 milhões de pessoas que possuem a maior parcela relativa de idosos na população total, conforme dados observados na Tabela 2.

As projeções demográficas para 2025 para esses países sinalizam que os idosos representarão cerca de um terço dos respectivos habitantes.

Tabela 2 - Maior proporção da população idosa em países com mais de 10 MM de pessoas

\begin{tabular}{|cc|cc|}
\hline \multicolumn{2}{|c|}{2002} & \multicolumn{2}{|c|}{2025} \\
\hline Itália & $24.5 \%$ & Japão & $35.1 \%$ \\
Japão & $24.3 \%$ & Itália & $34.0 \%$ \\
Alemanha & $24.0 \%$ & Alemanha & $33.2 \%$ \\
Grécia & $23.9 \%$ & Grécia & $31.6 \%$ \\
Bélgica & $22.3 \%$ & Espanha & $31.4 \%$ \\
Espanha & $22.1 \%$ & Bélgica & $31.2 \%$ \\
Portugal & $21.1 \%$ & Reino Unido & $29.4 \%$ \\
Reino Unido & $20.8 \%$ & Países Baixos & $29.4 \%$ \\
Ucrânia & $20.7 \%$ & França & $28.7 \%$ \\
França & $20.5 \%$ & Canadá & $27.9 \%$ \\
\hline
\end{tabular}

FONTE: ONU, 2001

Segundo os dados da Pesquisa Nacional por Amostra de Domicílios (IBGE, 2007), apresentados na Tabela 3, a população idosa no Brasil é formada por 19,1 milhões de pessoas, representando $10,2 \%$ da população total. A região Sudeste é a que possui a maior participação de habitantes acima de 60 anos de idade (11,3\%), enquanto que na região Norte os idosos representam apenas $6,5 \%$ da população.

Tabela 3 - População total e de 60 anos ou mais - Brasil 2007

\begin{tabular}{|c|c|c|c|c|c|c|c|c|}
\hline \multirow{4}{*}{ Regiões } & \multicolumn{8}{|c|}{ População } \\
\hline & \multirow{3}{*}{$\begin{array}{c}\text { Total } \\
\text { (MM } \\
\text { pessoas) }\end{array}$} & \multicolumn{7}{|c|}{ De 60 anos ou mais de idade } \\
\hline & & \multicolumn{2}{|c|}{ Total } & \multicolumn{5}{|c|}{ Distribuição percentual por faixa etária (\%) } \\
\hline & & $\begin{array}{l}\text { Absoluto } \\
\text { (MM } \\
\text { pessoas) }\end{array}$ & $\begin{array}{l}\text { Part } \\
(\%)\end{array}$ & $\begin{array}{c}60 \text { a } 64 \\
\text { anos }\end{array}$ & $\begin{array}{c}65 \text { a } 69 \\
\text { anos }\end{array}$ & $\begin{array}{c}70 \text { a } 74 \\
\text { anos }\end{array}$ & $\begin{array}{c}75 \text { a } 79 \\
\text { anos }\end{array}$ & $\begin{array}{l}80 \text { anos } \\
\text { oumais }\end{array}$ \\
\hline Brasil & 187,2 & 19,1 & 10,2 & 3,1 & 2,5 & 1,9 & 1,3 & 1,3 \\
\hline Norte & 15,1 & 1,0 & 6,5 & 2,2 & 1,7 & 1,1 & 0,8 & 0,7 \\
\hline Nordeste & 51,7 & 5,0 & 9,6 & 2,8 & 2,3 & 1,7 & 1,2 & 1,5 \\
\hline Sudeste & 79,8 & 9,0 & 11,3 & 3,4 & 2,8 & 2,2 & 1,5 & 1,4 \\
\hline Sul & 27,4 & 3,0 & 10,9 & 3,4 & 2,7 & 2,0 & 1,5 & 1,3 \\
\hline Centro-Oeste & 13,3 & 1,1 & 8,2 & 2,8 & 2,0 & 1,5 & 1,0 & 0,9 \\
\hline
\end{tabular}

FONTE: IBGE, 2007 
Tabela 4 - População total e de 60 anos ou mais - Sudeste 2007

\begin{tabular}{|c|c|c|c|c|c|c|c|c|}
\hline \multirow{4}{*}{$\begin{array}{l}\text { Regiões, Unidades } \\
\text { da Federação e } \\
\text { Área Metropolitana } \\
\text { (AM) }\end{array}$} & \multicolumn{8}{|c|}{ População } \\
\hline & \multirow{3}{*}{$\begin{array}{c}\text { Total } \\
\text { (MM } \\
\text { pessoas) }\end{array}$} & \multicolumn{7}{|c|}{ De 60 anos ou mais de idade } \\
\hline & & \multicolumn{2}{|c|}{ Total } & \multicolumn{5}{|c|}{ Distribuição percentual por faixa etária (\%) } \\
\hline & & $\begin{array}{l}\text { Absoluto } \\
\text { (MM } \\
\text { pessoas) }\end{array}$ & $\begin{array}{c}\text { Relativo } \\
(\%)\end{array}$ & $\begin{array}{c}60 \text { a } 64 \\
\text { anos }\end{array}$ & $\begin{array}{c}65 \mathrm{a} 69 \\
\text { anos }\end{array}$ & $\begin{array}{c}70 \text { a } 74 \\
\text { anos }\end{array}$ & $\begin{array}{c}75 \text { a } 79 \\
\text { anos }\end{array}$ & $\begin{array}{l}80 \text { anos } \\
\text { ou mais }\end{array}$ \\
\hline Sude: & 79,8 & 9,0 & 11 & 3,4 & 2,8 & 2,2 & 1,5 & 1,4 \\
\hline Minas Gerais & 19,5 & 2,1 & 10,9 & 3,3 & 2,7 & 2,2 & 1,3 & 1,4 \\
\hline AMB. Hori & 5,0 & 0,5 & 9,2 & 3,0 & 2, & 1,7 & 1 , & 1,2 \\
\hline Espírito San & 3,5 & 0,3 & 9,1 & 2,8 & 2,1 & 2 & 1,3 & 1,0 \\
\hline Rio de Janeiro & 15,6 & 2,2 & 14,1 & 4,1 & 3,6 & 2,7 & 2,0 & 1,7 \\
\hline AMR. Janeiro & 11,7 & 1,7 & 14,4 & 4,1 & 3,7 & 2,7 & 2,1 & 1,8 \\
\hline São Paı & 41,2 & 4,4 & 10,7 & 3,2 & 2,6 & 2,1 & 1,4 & 1,4 \\
\hline AMSão Paulo & 19,7 & 2,0 & 10,2 & 3,1 & 2,5 & 2,1 & 1,3 & 1,3 \\
\hline
\end{tabular}

FONTE: IBGE, 2007

Conforme observado na Tabela 4, é o Estado de São Paulo que possui o maior número de idosos, com 4,4 milhões de pessoas e, desses, 2 milhões residem na área metropolitana da capital. O Rio de Janeiro é a área metropolitana que apresenta a maior proporção de habitantes acima de 60 anos, com 14,4\% da população local.

Segundo o Relatório de Estatística Sanitária Mundial, divulgado pela Organização Mundial de Saúde (2007), a média da expectativa de vida dos brasileiros passou de 54,6 anos em 1960 para 72,3 anos em 2006.

O gênero e as desigualdades regionais influenciam esses números. Segundo o IBGE (2006), a média da esperança de vida dos homens é, ao nascer, de 68,5 anos, contra 76,1 anos das mulheres. A maior expectativa encontrada para os homens foi em Santa Catarina ( 71,8 anos) e a menor foi em Alagoas (62,4 anos). Com relação à situação das mulheres, o Distrito Federal é a região com maior expectativa (78,9 anos), enquanto que Alagoas, novamente, apresenta a menor expectativa (70,4 anos).

Estima-se que, em 2020, o Brasil chegue a 25,0 milhões de idosos diante de uma população total de 219,1 milhões, representando 11,4\% dos habitantes (IBGE, 2006). As reduções gradativas das taxas de mortalidade registradas nas últimas décadas, aliada com as quedas 
recorrentes das taxas de fecundidade, apontam para o envelhecimento irreversível da população brasileira (IBGE, 2006).

O fenômeno do envelhecimento crescente da população brasileira levanta problemas relevantes não somente aos legisladores, mas à comunidade em geral, visto que gera demandas diferenciadas por políticas públicas e altera a alocação dos recursos disponíveis. Uma das principais indagações que se pode fazer é se as estruturas, as políticas e os sistemas sociais e econômicos estão preparados para oferecer condições de vida dignas e adequadas aos seus membros que entram na chamada terceira idade.

Segundo Camarano (2008b), o aumento da expectativa de vida associa-se a um aumento no tempo em que os idosos vivenciariam doenças crônicas e outros distúrbios, provocando a redução de suas capacidades funcionais. Essa situação resultaria numa procura crescente por cuidados de longa duração, o que tradicionalmente recai sobre a família. Por outro lado, as famílias passam por alterações em suas estruturas, em que a mulher - tradicional cuidadora inseriu-se no mercado de trabalho com mais intensidade nas últimas décadas. Estima-se em $0,8 \%$ o total de idosos que se encontram institucionalizados no Brasil (CAMARANO, 2008b).

\subsubsection{Instituições de Longa Permanência para Idosos - ILPIs}

A partir da publicação da Resolução n ${ }^{0} 283 / 2005$ da Diretoria Colegiada da Agência Nacional de Vigilância Sanitária - ANVISA, adotou-se no Brasil a denominação de Instituição de Longa Permanência para Idosos para designar toda entidade governamental ou nãogovernamental destinada à moradia coletiva de pessoas com idade igual ou superior a 60 anos, com ou sem suporte familiar. Tal Resolução define as normas de funcionamento para as ILPIs e estabelece os seus padrões mínimos para funcionamento, a fim de que sejam oferecidas condições para que seus residentes exerçam seus direitos civis, políticos, econômicos, sociais, culturais e individuais (ANVISA, 2005).

Os residentes são classificados, pela legislação, conforme o grau de dependência que possuem de assistência direta para os seus cuidados pessoais. Há 3 graus de dependência para os idosos, listados a seguir: 
a) Grau I - pessoas independentes, mesmo que requeiram uso de equipamentos de autoajuda;

b) Grau II - pessoas sem comprometimento cognitivo ou com alteração cognitiva controlada, mas com dependência em até três atividades de autocuidado para a vida diária, tais como: alimentação, mobilidade, higiene;

c) Grau III - pessoas com dependência que necessitem de assistência diária para a realização de todas as atividades de autocuidado e/ou com comprometimento cognitivo.

Dentre as obrigações das ILPIs, destaca-se a adoção de práticas necessárias para:

a) Convivência mista entre os residentes de diversos graus de dependência;

b) Integração dos idosos nas atividades desenvolvidas pela comunidade local;

c) Desenvolvimento de atividades conjuntas com pessoas de outras gerações;

d) Participação da família e da comunidade na atenção ao residente;

e) Atividades que estimulem a autonomia dos idosos;

f) Promoção de atividades de lazer para os idosos, tais como: físicas, recreativas e culturais;

g) Prevenção e coibição de qualquer tipo de violência e discriminação contra os residentes.

O item 4.6 da Resolução 283/2005 estabelece que as ILPIs devem apresentar recursos humanos, com vínculo formal de trabalho, que garantam a realização das seguintes atividades: administrativa, cuidados, lazer, limpeza, alimentação e lavanderia. Essas atividades estão relacionadas diretamente aos produtos das ILPIs.

Como referência, as características das atividades e as condições de atuação dos profissionais mencionados são apresentadas no Quadro 2. 
Quadro 2 - Atividades exigidas para a ILPI

\begin{tabular}{|c|c|c|c|}
\hline Atividade & Qtde/Função & Carga horária & Obs \\
\hline Administrativa & 1 Responsável técnico & mínimo de $20 \mathrm{~h} /$ semana & para cada 20 idosos com GD* I \\
\hline \multirow{3}{*}{ Cuidados } & 1 Cuidador & $8 \mathrm{~h} /$ dia & para cada 10 idosos com GD* II \\
\cline { 2 - 4 } & 1 Cuidador & Turno & para cada 6 idosos com GD* III \\
\cline { 2 - 4 } & 1 Cuidador & Turno & para cada 40 idosos \\
\hline \multirow{2}{*}{ Lazer } & $\begin{array}{c}\text { 1 profissional de nível } \\
\text { superior }\end{array}$ & $12 \mathrm{~h} /$ semana & para cada $100 \mathrm{~m}^{2}$ de área interna \\
\hline Limpeza & 1 profissional & Turno & para cada 20 idosos \\
\hline Alimentação & 1 profissional & Turno & para cada 30 idosos \\
\hline Lavanderia & 1 profissional & Turno & \\
\hline
\end{tabular}

* Grau de dependência

FONTE: Adaptado de ANVISA, 2005

A Resolução 283/2005, em seu item 4.5.6, permite a terceirização dos serviços de alimentação, limpeza e lavanderia. Nesse caso, a ILPI estará dispensada de manter um quadro de trabalhadores próprios e área física específica para os respectivos serviços.

Conforme o item 5.3.1 dessa Resolução, a ILPI deverá oferecer, no mínimo, seis refeições diárias aos residentes.

As instalações físicas das ILPIs devem permitir a habitabilidade, higiene, salubridade, segurança e garantir a acessibilidade a todas as pessoas com dificuldade de locomoção segundo o estabelecido na Lei Federal 10.098/00.

Compete às instituições a realização continuada de avaliação do desempenho e padrão de funcionamento da instituição, pautando-se, ao menos, pelos indicadores de desempenho do Quadro 3, referentes ao ano anterior. Tais indicadores deverão constar de relatório a ser encaminhado ao órgão da Vigilância Sanitária local todo mês de janeiro. Os dados de cada município serão consolidados e deverão ser encaminhados à Secretaria Estadual de Saúde e, por sua vez, os dados consolidados estaduais deverão ser encaminhados à ANVISA e à Secretaria de Atenção à Saúde do Ministério da Saúde (ANVISA, 2005). 
Quadro 3 - Indicadores de desempenho para as ILPIs

\begin{tabular}{|c|c|c|c|}
\hline $\mathrm{N}^{\mathrm{o}}$ & Indicador & Fórmula e Unidade & $\begin{array}{l}\text { Frequência } \\
\text { de Produção }\end{array}$ \\
\hline 1 & $\begin{array}{l}\text { Taxa de mortalidade em } \\
\quad \text { idosos residentes }\end{array}$ & $\begin{array}{l}\text { (Número de óbitos de idosos residentes no mês / } \\
\left.\text { Número de idosos residentes no mês }{ }^{1}\right) * 100[\%]\end{array}$ & Mensal \\
\hline 2 & $\begin{array}{l}\text { Taxa incidência }{ }^{2} \text { de doença } \\
\text { diarréica aguda }{ }^{3} \text { em idosos } \\
\text { residentes }\end{array}$ & $\begin{array}{l}\text { (Número de novos casos de doença diarréica aguda em } \\
\text { idosos residentes no mês / Número de idosos residentes } \\
\text { no mês }{ }^{1} \text { ) }{ }^{*} 100[\%]\end{array}$ & Mensal \\
\hline 3 & $\begin{array}{l}\text { Taxa de incidência de } \\
\text { escabiose }{ }^{4} \text { em idosos } \\
\text { residentes }\end{array}$ & $\begin{array}{l}\text { (Número de novos casos de escabiose em idosos } \\
\text { residentes no mês / Número de idosos residentes no } \\
\left.\text { mês }^{1}\right) * 100[\%]\end{array}$ & Mensal \\
\hline 4 & $\begin{array}{l}\text { Taxa de incidência de } \\
\text { desidratação } 5 \text { em idosos } \\
\text { residentes }\end{array}$ & $\begin{array}{l}\text { (Número de idosos que apresentaram desidratação / } \\
\text { Número de idosos residentes no mês }{ }^{1} \text { ) } 100[\%]\end{array}$ & Mensal \\
\hline 5 & $\begin{array}{l}\text { Taxa de prevalência }{ }^{6} \text { de } \\
\text { úlcera de decúbito em idosos } \\
\text { residentes }\end{array}$ & $\begin{array}{l}\text { (Número de idosos residentes apresentando úlcera de } \\
\text { decúbito no mês/ Número de idosos residentes no mês }{ }^{1} \text { ) } \\
* 100[\%]\end{array}$ & Mensal \\
\hline 6 & $\begin{array}{l}\text { Taxa de prevalência de } \\
\text { desnutrição }{ }^{7} \text { em idosos } \\
\text { residentes }\end{array}$ & $\begin{array}{c}\text { (Número de idosos residentes com diagnóstico de } \\
\text { desnutrição no mês/ Número de idosos residentes no } \\
\left.\text { mês }^{1}\right) * 100[\%]\end{array}$ & Mensal \\
\hline
\end{tabular}

FONTE: ANVISA, 2005.

\section{A seguir, as notas explicativas do Quadro 3:}

1 - População exposta: considerar o número de idosos residentes do dia 15 de cada mês.

2 - Taxa de incidência: é uma estimativa direta da probabilidade ou risco de desenvolvimento de determinada doença em um período de tempo específico; o numerador corresponde aos novos casos, ou seja, aqueles iniciados no período em estudo.

3- Doença diarréica aguda: Síndrome causada por vários agentes etiológicos (bactérias, vírus e parasitas), cuja manifestação predominante é o aumento do número de evacuações, com fezes aquosas ou de pouca consistência. Com freqüência, é acompanhada de vômito, febre e dor abdominal. Em alguns casos, há presença de muco e sangue. No geral, é autolimitada, com duração entre 2 e 14 dias. As formas variam desde leves até graves, com desidratação e distúrbios eletrolíticos, principalmente quando associadas à desnutrição prévia.

4- Escabiose: parasitose da pele causada por um ácaro cuja penetração deixa lesões em forma de vesículas, pápulas ou pequenos sulcos, nos quais ele deposita seus ovos. As áreas preferenciais da pele onde se visualizam essas lesões são as regiões interdigitais, punhos (face anterior), axilas (pregas anteriores), região peri-umbilical, sulco interglúteo, órgãos genitais externos nos homens. Em crianças e idosos, podem também ocorrer no couro cabeludo, nas palmas e plantas. O prurido é intenso e, caracteristicamente, maior durante a noite, por ser o período de reprodução e deposição de ovos.

5- Desidratação: (perda de água) Falta de quantidade suficiente de líquidos corpóreos para manter as funções normais em um nível adequado. Deficiência de água e eletrólitos corpóreos por perdas superiores à ingestão. Pode ser causada por: ingestão reduzida (anorexia, coma e restrição hídrica); perda aumentada gastrointestinal (vômitos e diarréia), ou urinária (diurese osmótica, administração de diuréticos, insuficiência renal crônica e da supra-renal), ou cutânea e respiratória (queimaduras e exposição ao calor). 
6 - Taxa de prevalência: mede o número de casos presentes em um momento ou em um período específico; o numerador compreende os casos existentes no início do período de estudo, somados aos novos casos.

7 - Desnutrição: Condição causada por ingestão ou digestão inadequada de nutrientes. Pode ser causada pela ingestão de uma dieta não balanceada, problemas digestivos, problemas de absorção ou problemas similares. É a manifestação clínica decorrente da adoção de dieta inadequada ou de patologias que impedem o aproveitamento biológico adequado da alimentação ingerida. (ANVISA, 2005).

Todas as ILPIs existentes em 23 de setembro de 2005 (data da publicação da Resolução 283/2005), sem exceção, receberam um prazo de 24 meses para se adequarem às exigências legais. Dessa maneira, os primeiros relatórios sobre o desempenho das ILPIs foram entregues aos respectivos órgãos locais em janeiro de 2008.

Conforme o item 4.5.5 da Resolução 283/2005: “A Instituição de Longa Permanência para Idosos deve organizar e manter atualizados e com fácil acesso, os documentos necessários à fiscalização, avaliação e controle social."

O artigo 54 da Lei 10.741/2003 determina que seja dada publicidade das prestações de contas dos recursos públicos e privados recebidos pelas entidades de atendimento ao idoso.

\subsubsection{Alguns dados sobre as ILPIs no Brasil}

Coordenada por Camarano (2006, 2008a e 2008b), uma pesquisa do Instituto de Pesquisas Econômicas Aplicadas - IPEA iniciada em março de 2006 realiza um levantamento nacional sobre as características estruturais e operacionais das ILPIs em atividade. Tal estudo foi segmentado em cinco etapas, conforme as regiões geográficas analisadas (Norte, Sul, CentroOeste, Nordeste e Sudeste). Até maio de 2009, as ILPIs com e sem fins lucrativos das regiões Norte, Centro-Oeste e Sul, totalizando 991 organizações, foram mapeadas e tiveram algumas características identificadas. Prevê-se o término do levantamento das regiões Nordeste e Sudeste para os próximos anos.

Dentre os dados levantados pela equipe do IPEA, destacam-se: 
a) Quantidade e natureza das ILPIs

Tabela 5 - ILPIs por região

\begin{tabular}{|lccc|}
\hline & \multicolumn{3}{c|}{ Região } \\
\hline \multicolumn{1}{|c}{ Entidades } & $\mathrm{S}$ & $\mathrm{N}$ & $\mathrm{CO}$ \\
\hline \multicolumn{1}{|c}{ Quantidade identificada } & 693 & 49 & 249 \\
\hline \multicolumn{1}{|c}{ Natureza } & & & \\
Pública & $52 \%$ & $31 \%$ & $25 \%$ \\
Privada & $41 \%$ & $2 \%$ & $4 \%$ \\
Privada sem fins lucrativos* & $4 \%$ & $63 \%$ & $66 \%$ \\
Mista & $3 \%$ & $4 \%$ & $5 \%$ \\
\hline
\end{tabular}

* Originalmente classificado como filantrópica

FONTE: Adaptado de CAMARANO (2006, 2008a, 2008b)

Neste trabalho, a classificação utilizada na Tabela 5 foi alterada por 'Privada sem fins lucrativos' em substituição à denominação 'Privada filantrópica' devido ao critério classificatório utilizado por Camarano (2006, 2008a, 2008b), o qual não discrimina as entidades reconhecidas oficialmente como filantrópicas (portadoras do Certificado de Entidade de Beneficência e Assistência Social - CEBAS) daquelas que apenas se declaram sem fins lucrativos.

b) Características dos residentes

Tabela 6 - Características dos residentes por região

\begin{tabular}{|c|c|c|c|}
\hline & \multicolumn{3}{|c|}{ Região } \\
\hline Residentes & $\mathrm{S}$ & $\mathrm{N}$ & $\mathrm{CO}$ \\
\hline \multicolumn{4}{|l|}{ Gênero } \\
\hline Homens & $40 \%$ & $61 \%$ & $58 \%$ \\
\hline Mulheres & $60 \%$ & $39 \%$ & $42 \%$ \\
\hline \multicolumn{4}{|c|}{ Grau de dependência } \\
\hline Independentes & $38 \%$ & $44 \%$ & $32 \%$ \\
\hline Semidependentes & $31 \%$ & $25 \%$ & $29 \%$ \\
\hline Dependentes & $31 \%$ & $32 \%$ & $39 \%$ \\
\hline \multicolumn{4}{|c|}{ Residentes por entidade } \\
\hline $\mathrm{n}^{\mathrm{o}}$ médio & 29,19 & 24,80 & 28,56 \\
\hline até 10 & $14 \%$ & $29 \%$ & $17 \%$ \\
\hline de 11 a 20 & $34 \%$ & $29 \%$ & $30 \%$ \\
\hline de 21 a 30 & $21 \%$ & $12 \%$ & $20 \%$ \\
\hline de 31 a 50 & $18 \%$ & $20 \%$ & $22 \%$ \\
\hline acima de 50 & $13 \%$ & $10 \%$ & $11 \%$ \\
\hline
\end{tabular}

FONTE: CAMARANO (2006, 2008a, 2008b) 
c) Composição da mão-de-obra

Tabela 7 - Mão-de-obra por região

\begin{tabular}{|lrrr|}
\hline \multicolumn{4}{c}{ Região } \\
\hline Trabalhadores & $\mathrm{S}$ & $\mathrm{N}$ & $\mathrm{CO}$ \\
\hline assalariados & $78,80 \%$ & $79,10 \%$ & $65,00 \%$ \\
voluntários & $18,10 \%$ & $17,30 \%$ & $22,00 \%$ \\
cedidos & $3,10 \%$ & $3,60 \%$ & $13,00 \%$ \\
\hline
\end{tabular}

d) Origem das receitas

Tabela 8 - Origem das receitas por região

\begin{tabular}{|c|c|c|c|}
\hline & \multicolumn{3}{|c|}{ Região } \\
\hline ILPI's & $\mathrm{S}$ & $\mathrm{N}$ & $\mathrm{CO}$ \\
\hline Origem das receitas & & & \\
\hline residentes e/ou familiares & $67,40 \%$ & $20,20 \%$ & $31,30 \%$ \\
\hline doações privadas & $15,70 \%$ & $10,20 \%$ & $9,10 \%$ \\
\hline transfer. públicas & $10,70 \%$ & $64,80 \%$ & $55,40 \%$ \\
\hline geração própria & $6,20 \%$ & $4,90 \%$ & $4,20 \%$ \\
\hline
\end{tabular}

FONTE: CAMARANO (2006, 2008a, 2008b)

e) Características das despesas

Tabela 9 - Características das despesas por região

\begin{tabular}{|c|c|c|c|}
\hline & \multicolumn{3}{|c|}{ Região } \\
\hline ILPIs & $\mathrm{S}$ & $\mathrm{N}$ & $\mathrm{CO}$ \\
\hline Gasto mensal médio por entidade $\mathrm{R} \$$ & $18.569,96$ & $24.669,61 *$ & $13.688,76$ \\
\hline $\begin{array}{l}\text { Gasto mensal médio por residente } \mathrm{R} \$ \\
\text { Gastos por residente informados por entidade }\end{array}$ & 636,18 & $638,88^{*}$ & 479,24 \\
\hline menos de $\mathrm{R} \$ 500$ & $46,60 \%$ & $60,00 \%$ & $68,00 \%$ \\
\hline de $\mathrm{R} \$ 500$ a $\mathrm{R} \$ 1.000$ & $39,30 \%$ & $19,00 \%$ & $28,00 \%$ \\
\hline acima de $R \$ 1.000$ & $14,10 \%$ & $21,00 \%$ & $4,00 \%$ \\
\hline Destino dos gastos & & & \\
\hline funcionários & $48,90 \%$ & $55,50 \%$ & $44,60 \%$ \\
\hline alimentação & $16,40 \%$ & $18,00 \%$ & $18,20 \%$ \\
\hline manutenção e reparos da casa & $15,00 \%$ & $11,30 \%$ & $15,00 \%$ \\
\hline higiene pessoal & $4,30 \%$ & n.d. & n.d. \\
\hline medicamentos & $3,80 \%$ & $5,90 \%$ & $10,30 \%$ \\
\hline vestuário & $1,30 \%$ & $1,80 \%$ & $3,30 \%$ \\
\hline outros & $10,30 \%$ & $7,50 \%$ & $8,60 \%$ \\
\hline
\end{tabular}

n.d. = não disponível

* O valor do gasto mensal médio por residente da região Norte apresenta uma incompatibilidade com os valores informados em gasto mensal médio por entidade (R\$ $24.669,61)$ e o número médio de residentes por entidade $(24,80)$. Para um valor de gasto mensal médio de $\mathrm{R} \$ 638,88$, o valor estimado do gasto mensal médio por entidade deveria ser de R\$ 15.841,62. (NOTA DO AUTOR)

FONTE: CAMARANO (2006, 2008a, 2008b) 


\subsection{Transparência e divulgação}

A transparência pode ser definida através de várias abordagens conceituais. Em uma delas, relativa à observação das atividades da organização no mercado, Board et al. (2002) definem a transparência como a habilidade de observar, de forma razoável, os níveis atuais e recentes das atividades das organizações. A entidade transparente é, assim, aquela que permite ao observador externo ser analisada.

De acordo com Bushman et al. (2004), é preciso que informações sobre os aspectos principais das entidades estejam acessíveis aos interessados para ser caracterizada a transparência. Dessa maneira, a transparência seria proporcional ao nível de disponibilidade e oferecimento de informações, considerando-se a capacidade da organização em identificar, mensurar e comunicar as informações às partes interessadas. Entretanto, divulgar qualquer tipo de informação não elimina o problema da falta de transparência, já que a informação disseminada deve possuir qualidade e utilidade aos seus usuários.

Bushman e Smith (2003) alertam para a existência de fatores que podem obstruir a visão externa sobre as atividades e sobre fatos relevantes da entidade, tais como o receio de que informações estratégicas sejam divulgadas e prejudiquem aspectos competitivos de mercado ou, ainda, que não existam práticas disseminadas na cultura organizacional que favoreçam a divulgação de outras informações além daquelas obrigatórias. Conforme a legislação vigente, as informações de divulgação obrigatória podem ser mais ou menos amplas ou detalhadas, tanto nos aspectos financeiros quanto nos não-financeiros.

De forma geral, os pesquisadores consideram que a divulgação é um elemento fundamental para a caracterização da transparência.

\subsubsection{Divulgação}

Conforme Hendriksen e Van Breda (1999, p.512), a palavra divulgação, em seu sentido lato, significa veiculação da informação. Na literatura contábil e econômica é comum encontrar-se a utilização da palavra disclosure como sinônima de divulgação, guardando algumas diferenças na abrangência do termo conforme a intenção dos autores, mas sempre associadas 
à disponibilização de informações aos stakeholders de uma entidade, principalmente aos externos. Tratando-se de elementos-chave para qualquer processo decisório, os mecanismos a serem utilizados, prazos e características da divulgação podem estar legalmente regulados (como, por exemplo, as peças contábeis de divulgação obrigatória) ou não (como no caso da divulgação considerada voluntária).

Pesquisadores, como Watts e Zimmerman (1990), Verrechia (2001), Dye (2001), Sloam (2001), Kothari (2001), Healy e Palepu (2001), Bushman e Smith (2003), entre outros, apresentam vasto referencial de estudos empíricos envolvendo a divulgação financeira e seus reflexos junto aos diferentes grupos de interesse, com ênfase no mercado de capitais. O aumento e a redução da assimetria informacional entre os agentes econômicos têm sido estudados e relacionados com diversos tipos de risco, custo de capital, valor da empresa, governança etc. A contabilidade tem papel fundamental no processo de evidenciação das informações e na respectiva quebra de assimetria entre os agentes (LOPES, 2001).

Sob a perspectiva contábil, a divulgação de informações está, geralmente, relacionada aos aspectos financeiros da organização e oferece elementos para o processo de análise e tomada de decisão dos stakeholders relacionados. O disclosure, para Bushman e Smith (2003), é fundamental no processo decisório dos investidores, pois contribui para a avaliação das opções disponíveis para a aplicação de recursos de maneira mais eficiente, além de favorecer o monitoramento dos gestores das empresas e constituir-se, assim, como um elemento de governança.

\subsubsection{Disclosure social}

Uma vez que as informações divulgadas pelas empresas auxiliam a reduzir a assimetria entre as partes envolvidas, em um ambiente com diferentes stakeholders, a demanda por informações específicas pode pressionar as entidades a disponibilizarem relatórios que divulguem dados adicionais aos já comumente publicados. Para Hendriksen e Van Breda (1999), a complexidade das modernas relações da empresa com seus ambientes de atuação fomentou a ampliação dos grupos que têm interesse legítimo nos resultados e desempenho empresariais. 
Um conjunto de informações que vem recebendo atenção crescente é aquele relacionado às práticas de responsabilidade social das organizações. Ramanathan (1976) foi um dos pioneiros a tratar, sob o enfoque contábil, a questão da responsabilidade social e a evidenciação dos impactos sociais gerados pelas entidades privadas. $\mathrm{O}$ autor considerou aspectos centrais para o desenho de um arcabouço teórico da contabilidade social corporativa (o qual não se confunde, conceitualmente, com a contabilidade social presente na literatura econômica, que trata dos agregados macroeconômicos).

Os trabalhos iniciais de Ramanathan (1976) fomentaram a discussão sobre as relações existentes entre uma empresa, o mercado e a comunidade, além de levantarem alguns pontos que podem ser considerados atuais, como a necessidade de mensuração, avaliação e comunicação dos eventos relacionados a diferentes stakeholders, prestação de contas (accountability) e a demonstração do valor econômico agregado à sociedade.

Uma definição genérica sobre Disclosure Social é oferecida por O’Dwyer (2003, p. 528), o qual considera tratar-se da "[...] divulgação das informações sobre os impactos sociais causados pelas organizações."

Para Anderson e Frankle (1980), a divulgação pública de um conjunto de informações sobre o envolvimento da empresa com a comunidade, funcionários, meio-ambiente e benefícios dos produtos oferecidos é conhecido como Disclosure Social. Hackston e Milne (1996, p. 82) complementam ao afirmarem que o Disclosure Social é "[...] a provisão de informações financeiras e não-financeiras relacionadas à interação de uma organização com seus ambientes físico e social, como declarado nos relatórios corporativos anuais ou nos relatórios complementares."

Tilt (1994) argumenta que a divulgação social não ocorre, somente, pelas informações presentes nos relatórios anuais ou relatórios sociais, mas que também é caracterizada pela utilização de diversos tipos de mídias, considerando, também, a divulgação ocorrida via assessorias de imprensa e comunicação.

No Brasil, as informações sobre as atividades sociais corporativas são, geralmente, apresentadas nos relatórios anuais e divulgadas voluntariamente nos meios de comunicação pública da empresa, mas a simples divulgação de notícias em seus websites sobre a existência 
de políticas e programas sociais, sem a evidenciação dos fatos, não comprova o comprometimento nem dimensiona as ações sociais da organização junto aos diferentes públicos (MILANI FILHO, 2008a).

Contribuindo para a redução da assimetria informacional entre a organização e seus stakeholders, alguns instrumentos de evidenciação e certificação passaram a ser adotados, tais como: NBR 16001 (Associação Brasileira de Normas Técnicas), GRI Sustainability Report (Global Reporting Initiative), SA 8000 (Social Accountability Institute), AA 1000 (Institute of Social and Ethical Accountability), Indicadores de Responsabilidade Social (Instituto Ethos), além do Balanço Social.

Ullmann (1985) analisou a correlação do nível de disclosure voluntário das informações sociais com a postura estratégica da empresa, a força de pressão dos stakeholders e os desempenhos econômico e social, e concluiu que:

- A força de pressão dos stakeholders está positivamente correlacionada com o desempenho social;

- $\quad$ O desempenho social apresenta correlação indeterminada com desempenho econômico;

- $\quad$ O desempenho social está correlacionado positivamente com o disclosure social;

- $\quad$ O disclosure social apresenta correlação indeterminada com a postura estratégica.

A pesquisa de Ullmann (1985) sugere que o desempenho social da empresa é mais influenciado pela pressão exercida por grupos de interesse do que pelo desempenho econômico e, ainda, que o disclosure social está diretamente relacionado com o desempenho social, ou seja, as empresas aumentam a quantidade de informações divulgadas voluntariamente quanto mais favoráveis forem os resultados sociais.

\subsubsection{Indicadores de disclosure}

Conforme Nelson et al. (2003), um indicador de disclosure é um instrumento desenhado para medir a existência de um conjunto de itens específicos e, também, para avaliar a qualidade da divulgação de informações apresentadas. Ao somar-se a pontuação de cada item, a pontuação final indicará a quantidade e a qualidade dessa divulgação. Assim, para que o cálculo final seja representativo, os itens componentes do indicador devem ser selecionados por 
apresentarem relação direta ao contexto analisado e as respectivas pontuações devem seguir critérios coerentes para não distorcer os resultados.

Considerando que o nível de disclosure de uma organização é estimado sobre construções teóricas, faz-se necessário o levantamento de estudos anteriores sobre o assunto para o embasamento do indicador a ser utilizado na pesquisa atual.

$\mathrm{Na}$ literatura consultada, os trabalhos sobre indicadores de disclosure focam, predominantemente, a divulgação voluntária de itens financeiros e não-financeiros das empresas de mercado, como encontrado em Botosan (1997), Hail (2002), Eng e Mak (2003), Lanzana (2004) e Bhojraj et al. (2004). Em todos eles, os próprios autores ressalvam as limitações da aplicabilidade de seus indicadores, uma vez que consideram grupos específicos de empresas e regiões abrangidas. Para Francis et al. (2008), métricas de disclosure têm a desvantagem de não poderem ser replicadas facilmente porque são elaboradas considerando o julgamento subjetivo do pesquisador, o qual pode aumentar ou diminuir, por conveniência, o peso dos itens que serão considerados no estudo.

A Tabela 10, a seguir, apresenta um resumo dos principais tipos de informações coletadas para a construção de indicadores sobre disclosure voluntário: 
Tabela 10 - Principais informações utilizadas em indicadores de disclosure voluntário

\begin{tabular}{|c|c|c|c|}
\hline Autores & Grupos & & $\mathrm{n}^{\mathrm{o}}$ de itens \\
\hline \multirow{6}{*}{ Botosan } & Informações gerais & & 6 \\
\hline & Sumário dos resultados históricos & & 5 \\
\hline & Informações não-financeiras & & 8 \\
\hline & Informações projetadas & & 5 \\
\hline & Discussão e análise da administração & & 11 \\
\hline & & total & 35 \\
\hline \multirow{4}{*}{ Hail } & Informações gerais e não-financeiras & & 10 \\
\hline & Análise e discussão de tendências e análise gerencial & & 10 \\
\hline & Riscos, informações baseadas em valor e projeções & & 7 \\
\hline & & total & 27 \\
\hline \multirow{4}{*}{ Eng e Mak } & Informações estratégicas & & 23 \\
\hline & Informações não-financeiras & & 5 \\
\hline & Informações financeiras & & 18 \\
\hline & & total & 46 \\
\hline \multirow{5}{*}{ Lanzana } & Informações gerais e não-financeiras & & 11 \\
\hline & Informações financeiras adicionais & & 5 \\
\hline & Análise e discussão de tendências e análise gerencial & & 10 \\
\hline & Riscos, criação de valor e projeções & & 7 \\
\hline & & total & 33 \\
\hline \multirow{4}{*}{ Bhojraj et al } & Informações estratégicas & & 4 \\
\hline & Informações financeiras & & 6 \\
\hline & Informações gerais e não-financeiras & & 3 \\
\hline & & total & 13 \\
\hline
\end{tabular}

Para a construção dos indicadores de disclosure nos estudos citados foram adotados critérios de características quantitativas e qualitativas para cada item, basicamente constatando-se a presença da informação analisada. Os indicadores foram, portanto, o resultado da análise em conjunto dos itens selecionados.

Com relação aos estudos voltados às OTS, envolvendo transparência e disclosure, a literatura consultada concentra-se na investigação da qualidade e da quantidade das informações disponibilizadas ao público, enfatizando os aspectos de prestação de contas (accountability) e conformidade legal (compliance).

Ramanathan (1976), Hackston e Milne (1996), Gordon et al. (1999, 2002), Froelich et al. (2000), Jegers (2002), Glaeser (2003), Flack (2004), Flack e Ryan (2005), Behn et al. (2007) e Francis et al. (2008) exploraram as práticas de auditoria, prestação de contas e a ocorrência de disclosure obrigatória e voluntária em OTS; Hansmann (1986), Herlinzer e Nitterhouse (1994), Shim e Siegel (1997), Gantz (1999), Keating e Frumkin (2001, 2003), Toder (2006) e Krishnan et al. (2006) investigaram os aspectos normativos contábeis e as demonstrações 
financeiras obrigatórias para as OTS; Ullmann (1985), Weisbrod e Schlesinger (1986) e Tilt (1994) pesquisaram o disclosure e a assimetria informacional entre OTS e seus stakeholders; Anderson e Frankle (1980), O’Dwyer (2003) estudaram as práticas gerenciais e a caracterização do disclosure social, Nelson et al. (2003) e Guo e Saxton (2007) realizaram estudos que envolviam a elaboração de indicadores de disclosure. No Brasil, autores como Araújo (2005), Szazi (2006), Oliveira e Romão (2006), Olak e Nascimento (2008), entre outros, apresentaram, detalhadamente, as normas e regras legais pertinentes às OTS, com ênfase nos aspectos fiscais, previdenciários, trabalhistas e contábeis.

Alguns itens informacionais considerados nas entidades de mercado, tais como relação com os acionistas e distribuição de resultados, não se aplicam diretamente às organizações sem fins lucrativos. Por sua vez, a divulgação de informações como, por exemplo, as relacionadas a doações recebidas ou ao número de voluntários em atividade, também não constam, usualmente, dos relatórios operacionais das empresas do Segundo Setor.

Sob o aspecto normativo brasileiro, as entidades são obrigadas, por força de lei, a preparar relatórios específicos sobre suas atividades e situação patrimonial com determinada periodicidade. Conforme a Norma Brasileira de Contabilidade Técnica (NBC-T) $\mathrm{n}^{\mathrm{o}}$ 6, que trata da divulgação financeira, em seu item 6.1.2.1, a divulgação tem por objetivo "[...] fornecer, aos seus usuários, um conjunto mínimo de informações de natureza patrimonial, econômica, financeira, legal, física e social que lhes possibilitem o conhecimento e a análise da situação da Entidade.” (CFC, 1992).

Com relação à forma de apresentação, em seu item NBC-T 6.1, tem-se:

$[\ldots]$

6.1.1 - CONCEITO

6.1.1.1 - A divulgação é o ato de colocar as demonstrações contábeis da Entidade à disposição de seus usuários.

6.1.1.2 - São meios de divulgação:

a) a publicação das demonstrações contábeis na imprensa, oficial ou privada, em qualquer das suas modalidades;

b) a remessa das demonstrações contábeis a titulares do capital, associados, credores, órgãos fiscalizadores ou reguladores, bolsas de valores, associações de classe, entidades de ensino e pesquisa, e outros interessados;

c) a comunicação de que as demonstrações contábeis estão à disposição dos titulares do capital, associados e demais interessados, em local ou locais identificados. 
As notas explicativas, que são parte integrante das demonstrações contábeis, devem apresentar informações mínimas, conforme estabelecido a seguir (NBC-T 6.2):

\section{$[\ldots]$}

6.2.2.2 - As informações contidas nas notas explicativas devem ser relevantes, complementares e/ou suplementares àquelas não suficientemente evidenciadas ou não constantes nas demonstrações contábeis propriamente ditas.

6.2.2.3 - As notas explicativas incluem informações de natureza patrimonial, econômica, financeira, legal, física e social, bem como os critérios utilizados na elaboração das demonstrações contábeis e eventos subseqüentes ao balanço.

\subsection{3 - ASPECTOS A OBSERVAR NA ELABORAÇÃO DAS NOTAS EXPLICATIVAS}

6.2.3.1 - Os seguintes aspectos devem ser observados na elaboração das notas explicativas:

a) as informações devem contemplar os fatores de integridade, autenticidade, precisão, sinceridade e relevância;

b) os textos devem ser simples, objetivos, claros e concisos;

c) os assuntos devem ser ordenados obedecendo a ordem observada nas demonstrações contábeis, tanto para os agrupamentos como para as contas que os compõem;

d) os assuntos relacionados devem ser agrupados segundo seus atributos comuns;

e) os dados devem permitir comparações com os de datas de períodos anteriores;

f) as referências a leis, decretos, regulamentos, normas brasileiras de contabilidade e outros atos normativos devem ser fundamentadas e restritas aos casos em que tais citações contribuam para o entendimento do assunto tratado na nota explicativa.

Seguindo a NBC-T 10.19 (CFC, 2000), todas as organizações sem fins lucrativos sujeitam-se a NBC-T n $n^{\circ} 6$ e às demais normas estabelecidas pelo Conselho Federal de Contabilidade, como observado a seguir.

$[\ldots]$

10.19.1.6 - Aplicam-se às entidades sem finalidade de lucros os Princípios Fundamentais de Contabilidade, bem como as Normas Brasileiras de Contabilidade e suas Interpretações Técnicas e Comunicados Técnicos, editados pelo Conselho Federal de Contabilidade.

$[\ldots]$

Para a verificação do nível de disclosure das OTS podem-se considerar, dessa maneira, os itens de divulgação obrigatória pela legislação vigente e, também, aqueles de natureza voluntária, tanto relacionados aos aspectos financeiros como aos aspectos não-financeiros. 
Baseando-se nas normas do Conselho Federal de Contabilidade (1992, 2000), destacam-se 10 itens de divulgação obrigatória, apresentados no Quadro 4:

Quadro 4 - Itens de divulgação obrigatória para as OTS

\begin{tabular}{|lr|}
\hline \multicolumn{1}{|c}{ Itens obrigatórios } & ref. NBC-T \\
\hline Disponibilização das demonstrações contábeis aos seus usuários & 6.1 .1 .1 \\
Publicação na imprensa oficial ou privada, em qualquer de suas modalidades & 6.1 .1 .2 \\
Remessa das demonstrações contábeis a todos os interessados & 6.1 .1 .2 \\
Comunicação de que as demonstrações contábeis estão à disposição & 6.1 .1 .2 \\
Publicação das Notas Explicativas & 6.2 .2 .1 \\
Segregação de contas de receitas e despesas por atividades & 10.19 .2 .5 \\
Informações sobre os critérios de apuração das receitas e despesas & 10.19 .3 .3 \\
Demonstração das isenções previdenciárias (INSS) & 10.19 .3 .3 \\
Montante das subvenções recebidas & 10.19 .3 .3 \\
Descrição das condições (taxas, prazos etc) das obrigações de longo prazo & 10.19 .3 .3 \\
\hline
\end{tabular}

Ao pesquisarem a divulgação voluntária de 107 OTS americanas em seus respectivos websites, Guo e Saxton (2007) consideraram itens relacionados a: informações financeiras, informações sobre o desempenho, informações sobre prestação de contas e informações gerais. Ao todo, os autores trabalharam com 47 itens, sendo 9 itens financeiros, 16 itens de desempenho, 13 itens de transparência e 9 itens gerais. A constatação da presença de cada item acrescia um ponto na soma geral da entidade e a ausência não era pontuada. Todos os itens possuíam o mesmo peso para o cálculo do score final.

Nelson et al. (2003) elaboraram um indicador de disclosure para analisar e comparar as informações disponibilizadas por 48 universidades canadenses, considerando 26 itens relacionados a: informações gerais, informações financeiras, informações sobre o desempenho e informações sobre as condições físicas das instituições analisadas. A pontuação de cada item variava de 0 (informação ausente) até 5 (informação presente e com qualidade considerada ótima). Alguns itens possuíam peso maior que outros, conforme os critérios arbitrados pelos autores.

Tanto a pesquisa de Guo e Saxton (2007) quanto a de Nelson et al. (2003), consideraram itens financeiros e não-financeiros para a construção dos indicadores de disclosure em OTS, destacando-se a presença de informações sobre o desempenho e sobre o processo de prestação de contas. 


\subsection{Eficiência, eficácia e efetividade}

Apesar de serem comumente utilizados em textos de diferentes áreas do conhecimento, os termos eficiência, eficácia e efetividade não possuem definições conceituais absolutas. Como observam Silva e Formigli (1994), frequentemente se verifica uma superposição dos significados desses termos, os quais chegam a ser utilizados como sinônimos.

O conceito de eficiência encontrado na literatura contábil está, geralmente, relacionado com a definição apresentada por Hendriksen e Van Breda (1999) e Atkinson et al. (2000), como sendo a utilização ótima de recursos escassos para se produzir alguma coisa. Marinho e Façanha (2001, p. 2) definem eficiência como a expressão da "[...] competência para se produzir resultados com dispêndio mínimo de recursos e esforços." Nakagawa (1987) e Bio (1996, p. 12) entendem que esse conceito se relaciona ao "[...] modo certo de se fazer as coisas.” e ambos apontam que eficiência é definida pela razão entre quantidade produzida e recursos consumidos.

Uma medida relacionada aos produtos e aos insumos é a produtividade, caracterizada pela divisão da quantidade dos produtos pela quantidade dos insumos (HORNGREN et al., 2004). Nesse sentido, eficiência e produtividade estão intrinsecamente associadas e são calculadas, por autores como Nakagawa (1987, p.34), Bio (1996, p.20), Marinho (2001, p.7), Berman (2006, p.150) e Cooper et al. (2007, p.1) pela mesma relação outputs/inputs, apenas enfatizando que a variável a ser utilizada no denominador como insumo para se medir a produtividade é, usualmente, a mão-de-obra. Na literatura, entretanto, há autores que preferem adotar a relação inputs/outputs para se referirem à medida de eficiência, como Horngren et al. (2004).

Sobre o conceito de eficácia, Nakagawa (1987), Rundall apud Silva e Formigli (1994), Bio (1996), Marinho e Façanha (2001) entendem que essa se caracteriza pelo alcance e cumprimento das metas e objetivos propostos, assim como Horngren et al. (2004, p. 270) a concebem representando o "[...] grau em que uma meta, um objetivo ou um alvo é alcançado."

A Ilustração 2, a seguir, esquematiza a relação entre eficiência e eficácia. 


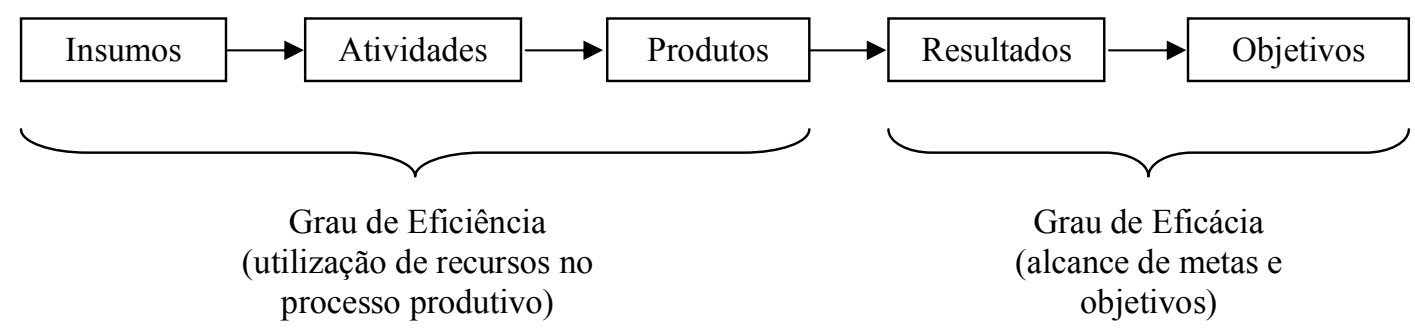

Ilustração 2 - Eficiência e eficácia

Efetividade é um termo encontrado, predominantemente, na literatura relacionada à área de saúde e programas sociais (SILVA; FORMIGLI, 1994; MARINHO; FAÇANHA, 2001). Basto et al. (1993) entendem que efetividade refere-se "àquilo que pode ser visto e sentido pelo cliente". Campos apud Silva e Formigli (1944) relaciona a efetividade como uma situação decorrente de algo eficiente e eficaz, simultaneamente. Ao se utilizar o mínimo de recursos possíveis e, simultaneamente, atingir os objetivos propostos, conceitua-se a efetividade. Assim, para se caracterizar algo como efetivo, necessariamente os resultados obtidos no processo produtivo devem atingir os objetivos previamente definidos (eficácia) com a utilização ótima de recursos (eficiência).

Silva e Formigli (1994), entretanto, destacam que o entendimento conceitual de efetividade, ao menos na área de saúde, vem evoluindo desde a década de 1970, e atualmente se relaciona aos efeitos obtidos em decorrência de determinados resultados. Nesse sentido, efetividade estaria vinculada ao impacto proporcionado por determinada ação. Marinho e Façanha (2001) corroboram essa posição com relação a projetos sociais, entendendo que efetividade se relaciona aos efeitos provocados por determinadas ações e programas, mas esses autores entendem que a efetividade não está vinculada com eficiência e, contrariamente a Campos apud Silva e Formigli (1994), acreditam que a efetividade e a eficiência "[...] são ingredientes indispensáveis da eficácia.” (MARINHO; FAÇANHA, 2001, p. 12).

Para os propósitos deste trabalho, os conceitos utilizados de eficiência, eficácia e efetividade são:

- Eficiência: grau de utilização de recursos escassos para se produzir alguma coisa.

- Eficácia: grau em que uma meta, um objetivo ou um alvo é alcançado.

- Efetividade: medida do alcance das ações realizadas em determinado ambiente. 


\subsubsection{Eficiência econômica}

Uma métrica comumente calculada para a avaliação do desempenho de organizações é a eficiência econômica. Segundo Farrel (1957), a eficiência econômica apresenta, distintamente, os componentes produtivos (técnicos) e alocativos.

A eficiência produtiva (técnica) é a capacidade de uma empresa de produzir o máximo possível, dada uma quantidade limitada de fatores disponíveis ou, ainda, reduzir ao mínimo possível a quantidade necessária de insumos para se produzir uma dada quantidade de produtos.

A eficiência alocativa considera valores monetários ao relacionar-se à utilização ótima dos fatores de produção e à minimização dos custos produtivos ou maximização da receita. Dessa maneira, é a capacidade de se combinar os recursos disponíveis a fim de se obter resultados em proporções ótimas dados os preços vigentes (BELLONI, 2000).

As métricas de eficiência são geralmente relacionadas a funções de fronteiras num sistema de coordenadas, considerando-se eficiente a firma que se posiciona sobre essas fronteiras (COELLI et al., 1998). No aspecto produtivo, a empresa eficiente consegue produzir o máximo possível conforme suas restrições. Dessa maneira, a empresa ineficiente apresenta coordenadas que se encontram abaixo da fronteira produtiva.

A mensuração da eficiência pode ser orientada para o insumo ou para o produto. A seguir, o Gráfico 4 exemplifica a representação da eficiência com orientação ao produto e, ainda, considerando-se retornos constantes de escala. 


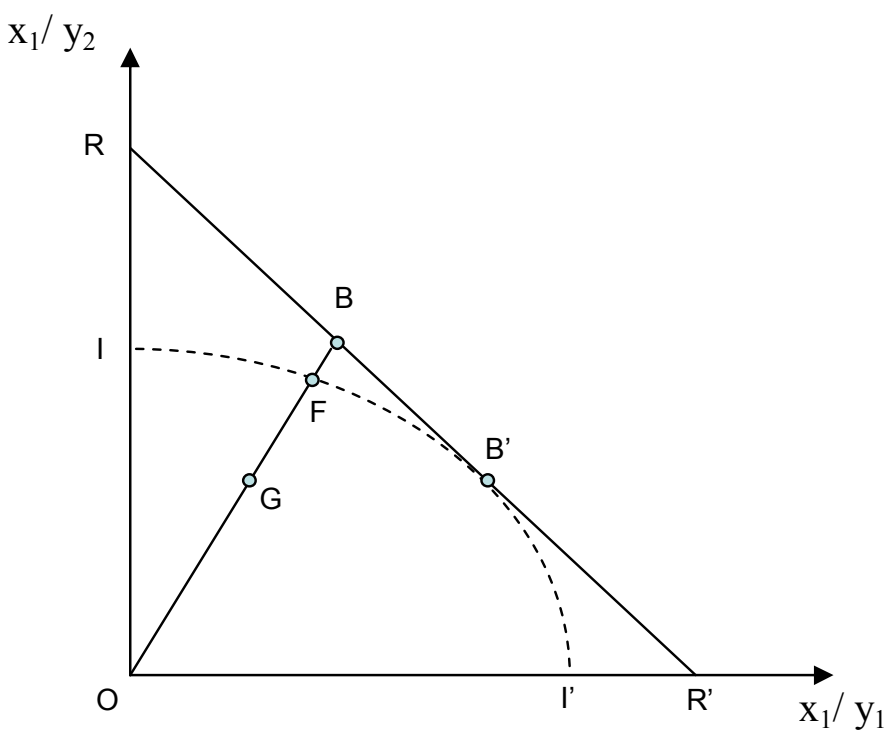

Gráfico 4 - Eficiência orientada ao produto FONTE: adaptado de COELLI et al., 1998

No Gráfico 4, dada a produção de dois bens (y1 e y2) com apenas um tipo de insumo (x1) e determinada tecnologia, a fronteira de possibilidades de produção é representada pela curva II'.

O ponto F, situando-se sobre a fronteira de produção, caracteriza-se como um plano produtivo tecnicamente eficiente. $\mathrm{O}$ ponto $\mathrm{G}$ caracteriza-se como um plano produtivo tecnicamente ineficiente por não atingir a curva I-I'. A distância entre os pontos F e G é utilizada para medir o grau de eficiência técnica (ET), a qual varia entre 0 e 1, apresentada a seguir:

$$
E T=\frac{O G}{O F}
$$

Qualquer ponto situado sobre a curva de isoreceitas é caracterizado como eficiente alocativamente, ou seja, a combinação dos produtos vendidos obtém a maior receita possível. A medida de eficiência alocativa utiliza como referência a distância entre o ponto sobre a fronteira produtiva e a curva de eficiência alocativa. No Gráfico 4, a distância entre os pontos F e B representa a diminuição da receita devido ao fato de que a produção não se verifica no mesmo ponto de eficiência alocativa. 
Assim, o grau de eficiência alocativa (EA), também variando entre 0 e 1, é calculado por:

$$
E A=\frac{O F}{O B}
$$

A eficiência econômica (EE) é mensurada, por sua vez, levando-se em conta as medidas ET e EA, da seguinte maneira:

$$
E E=\frac{O G}{O F} * \frac{O F}{O B}=\frac{O G}{O B}
$$

Uma empresa plenamente eficiente economicamente apresenta um plano de produção, portanto, cuja métrica $\mathrm{EE}=1$.

Assim, para se estudar a eficiência econômica de determinados agentes faz-se necessário relacionarem-se valores monetários e não-monetários aos insumos e aos produtos selecionados. Nas pesquisas sobre eficiência em que não são consideradas informações financeiras sobre receitas e custos, mas levam-se em conta dados quantitativos nãomonetários relacionados aos insumos e aos respectivos produtos, centra-se a análise da eficiência sob o aspecto produtivo diante da indisponibilidade ou da desconsideração de dados monetários necessários à mensuração da eficiência alocativa.

Nas OTS, cujos produtos são, frequentemente, oferecidos em gratuidade ou comercializados por valores estabelecidos sem a preocupação da maximização da receita, a eficiência alocativa pode ser influenciada negativamente.

Para o desenvolvimento deste trabalho, a eficiência alocativa não foi considerada devido à natureza filantrópica dos serviços prestados pelas entidades, que supostamente não objetivam a maximização da receita financeira, apesar da possibilidade da minimização dos custos. Dessa maneira, esta pesquisa voltou-se, apenas, à investigação da eficiência produtiva. 


\subsection{Análise envoltória de dados - DEA}

Desenvolvida a partir do trabalho de Charnes, Cooper e Rhodes (1978), os quais se serviram de conceitos sobre eficiência inicialmente explorados por Farrel (1957), a Análise Envoltória de Dados (Data Envelopment Analysis - DEA) é comumente utilizada para avaliar a eficiência produtiva de determinado grupo formado por unidades tomadoras de decisão (Decision Making Units - DMUs) baseando-se em problemas de programação linear. Genericamente, uma DMU é entendida como uma entidade responsável por converter insumos em produtos e cujo desempenho pode ser avaliado (COOPER et al., 2007).

Para Sengupta e Sahoo (2006), a DEA preencheu uma lacuna existente em diferentes situações de avaliação de desempenho em que modelos paramétricos enfrentam impedimentos formais para os respectivos cálculos, particularmente pela complexidade das relações entre múltiplos insumos e múltiplos produtos expressos, frequentemente, em unidades que não permitem a comparação direta. Diferentemente do cálculo de regressão linear, por exemplo, que estabelece uma reta que melhor se ajusta aos dados observados ao buscar os menores desvios possíveis entre eles e a reta (CORRAR et al., 2003, p.80), a DEA é uma técnica nãoparamétrica que constrói uma fronteira de produção eficiente e compara as diferentes DMUs pela distância em que se encontram dela. Quanto mais próxima da fronteira encontra-se uma DMU, mais eficiente ela é em relação às demais unidades. Assim, aquelas que se localizam sobre a fronteira são consideradas plenamente eficientes em comparação ao grupo estudado. Supondo apenas um insumo e um produto, o Gráfico 5 apresenta uma comparação visual entre a fronteira calculada pela DEA com a reta de regressão linear.

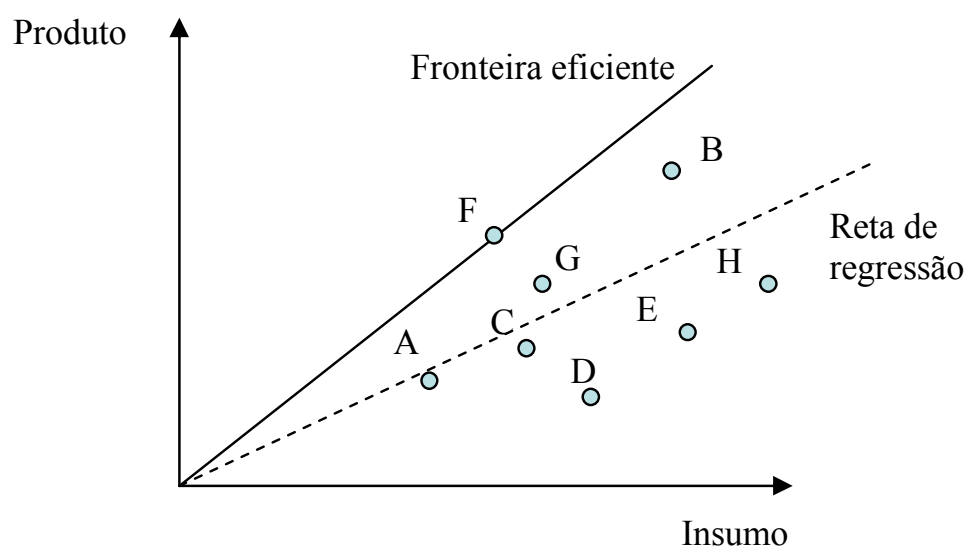

Gráfico 5 - Comparação entre DEA e regressão linear FONTE: COOPER et al., 2007. 
Um pressuposto fundamental nessa técnica é que, se uma determinada $\mathrm{DMU}_{\mathrm{A}}$ for capaz de produzir Y (A) produtos utilizando-se de X (A) insumos, então outras DMUs também podem ser capazes de fazer o mesmo se apresentarem um comportamento eficiente. Igualmente, se a $\mathrm{DMU}_{\mathrm{B}}$ for capaz de produzir Y (B) unidades de produção com X (B) insumos, então outras DMUs também serão capazes de produzir a mesma quantidade com os mesmos insumos. Dessa maneira, as DMUs A, B e as demais que compõem o grupo de análise são consideradas, simultaneamente, para a criação de uma DMU virtual, formada por uma combinação eficiente das demais unidades.

O ponto central da DEA, portanto, está em encontrar-se a melhor DMU virtual para cada uma das DMUs existentes. Se a DMU virtual é melhor do que a DMU inicial, seja produzindo mais com os mesmos insumos, seja consumindo menos para produzir a mesma quantidade, então a DMU inicial é ineficiente.

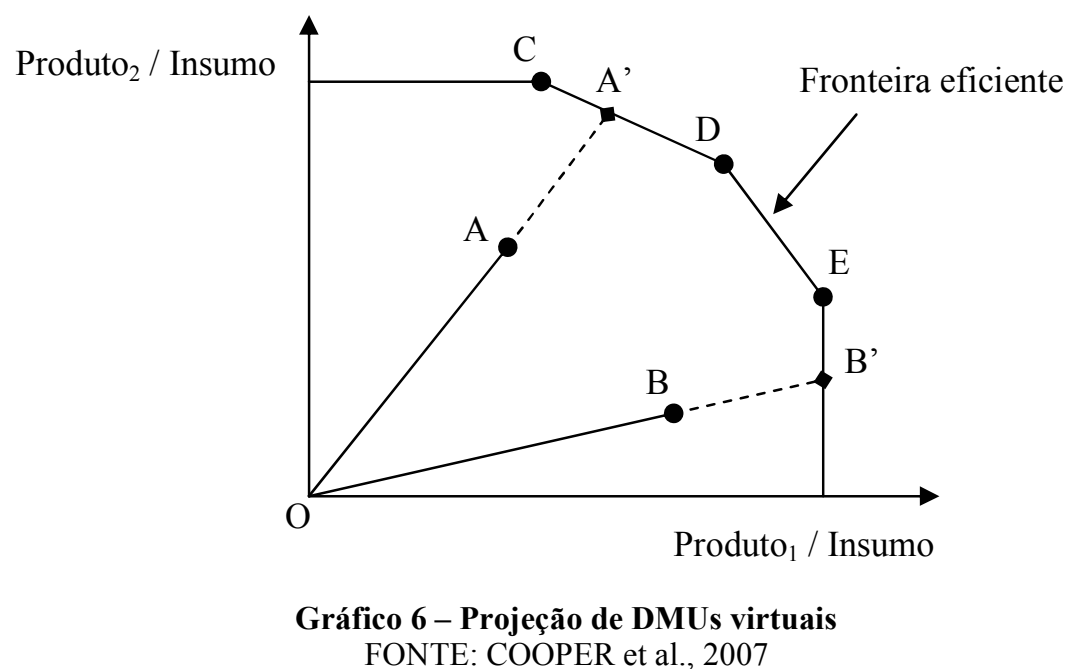

Conforme observado no Gráfico 6, em que se considerou a existência de um insumo e dois produtos, as DMUs C, D e E são consideradas eficientes por estarem sobre a fronteira produtiva, mas as DMUs A e B são consideradas ineficientes por estarem distantes da fronteira. As DMUs virtuais A' e B' das respectivas unidades A e B são obtidas quando projetadas, matematicamente, na fronteira de produção. Os pontos A' e B' são considerados os alvos a serem atingidos e, consequentemente, os benchmarks. A ineficiência é mensurada pela distância entre a DMU virtual e a DMU observada. 
Considerando-se o Gráfico 6, a eficiência $h_{A}$ da $\mathrm{DMU}_{\mathrm{A}}$ é calculada pela razão entre a distância da origem $\mathrm{O}$ ao ponto A sobre a distância da origem $\mathrm{O}$ ao ponto A'.

$$
h_{A}=\frac{d(O, A)}{d\left(O, A^{\prime}\right)}
$$

$\mathrm{O}$ resultado desse cálculo se situará em $0 \leq h_{A} \leq 1$. A distância entre os pontos A e A', portanto, corresponde ao grau de ineficiência técnica da DMU no conjunto analisado.

O processo para se encontrar a melhor DMU virtual assume a forma de um problema de programação linear. Ao analisar-se a eficiência de "n" produtores tem-se um conjunto de "n" problemas de programação linear (PPL).

Se o objetivo do cálculo for minimizar a quantidade necessária de insumos para um mesmo volume de produção, diz-se que a DEA é orientada aos insumos. Do contrário, caso se pretenda maximizar a quantidade produzida com determinada quantidade de insumos, então se diz que a DEA é orientada aos produtos.

Outro aspecto relevante a ser considerado na DEA é a adoção, ou não, da suposição de que as DMUs possuem retorno constante ou variável de escala. Se for indiferente para a eficiência da DMU produzir-se uma pequena ou uma grande quantidade de produtos, pode-se calcular o respectivo grau de eficiência mantendo-se constantes os retornos de escala (Constant Return to Scale-CRS). Essa foi a premissa adotada por Charnes, Cooper e Rhodes (1978) nos trabalhos iniciais sobre DEA, o que posteriormente ficou conhecido como modelo CCR. A suposição de retornos variáveis de escala (Variable Return to Scale - VRS) na DEA foi introduzida por Banker, Charnes e Cooper (1984), cujo modelo ficou conhecido pelas iniciais de seus autores como modelo BCC. Assim, a estimativa da eficiência produtiva pode ser realizada pelos modelos CCR e BCC, ambos orientados para os insumos ou para os produtos.

Angulo Meza (1998) afirma que a modelagem por DEA deve cumprir três etapas:

I. Definição e seleção de DMUs - O conjunto de DMUs adotado deve ter a mesma natureza e utilização de entradas (inputs) e saídas (outputs), variando apenas em 
intensidade. Deve haver homogeneidade nas atividades básicas e nos objetivos das DMUs, as quais devem trabalhar nas mesmas condições de mercado e ter autonomia na tomada de decisões.

II. Definição e seleção das variáveis - A escolha das variáveis de entrada e de saída deve ser realizada a partir de uma ampla lista de possíveis variáveis ligadas ao modelo, a fim de permitir maior conhecimento sobre as unidades a serem avaliadas e explicar melhor suas diferenças.

III. Escolha e aplicação do modelo - A escolha do modelo DEA implicará em se analisar as unidades conforme as premissas de retorno constante (CCR) ou variável (BCC) de escala, assim como determinar se a eficiência será enfocada pela redução dos inputs (orientação aos insumos) ou pelo aumento dos outputs (orientação aos produtos).

Em qualquer um de seus modelos, a análise envoltória de dados representa uma ferramenta relevante para o próprio processo interno de gestão das unidades observadas, assim como permite a definição de estratégias para se transformar unidades ineficientes em eficientes, tomando-se como referência outras DMUs e os benchmarks projetados. Logo, a DEA também é utilizada para benchmarking.

As vantagens apontadas pela literatura sobre a utilização da DEA são:

a) diferentemente das abordagens econométricas, os dados não necessitam de normalização;

b) é uma técnica não-paramétrica e, assim, não exige uma forma funcional explícita relacionando insumos e produtos;

c) não necessita de informações sobre valores monetários para ser aplicada;

d) apresenta flexibilidade de aplicação, pois permite a inclusão e exclusão de variáveis;

e) pode-se redefinir grupos de DMUs;

f) pode-se atribuir e alterar os pesos dos insumos e produtos na formulação matemática;

g) além de apontar o grau de eficiência, pode apontar os possíveis melhoramentos a serem perseguidos.

As limitações da DEA são: 
a) os resultados são válidos apenas para o cálculo da eficiência relativa ao grupo considerado;

b) quanto maior o número de variáveis selecionadas, maior a probabilidade de existirem muitas DMUs sobre a fronteira eficiente e menor o poder discriminatório entre elas.

\subsubsection{Comparação gráfica dos modelos CCR e BCC}

O Gráfico 7 compara os modelos CCR e BCC com orientação aos insumos, considerando uma situação de análise em que as DMUs utilizam apenas um insumo para a produção de um único produto. O número representativo do produto é fixo, pois os modelos são orientados aos insumos. A $\mathrm{DMU}_{\mathrm{F}}$, por exemplo, é considerada ineficiente em ambos os modelos, pois não se situa sobre as fronteiras de produção eficiente. As distâncias entre a $\mathrm{DMU}_{\mathrm{F}}$ e suas $\mathrm{DMUs}$ virtuais são expressas pelos segmentos $\overline{F F^{\prime \prime}}$ (CCR-I) e $\overline{F F^{\prime}}$ (BCC-I). O grau de eficiência calculado variará, portanto, conforme o modelo adotado.

Pelo modelo CCR-I, a eficiência é dada pela razão $\frac{\overline{F^{\prime \prime} P f}}{F P f}$ e pelo modelo BCC-I, a eficiência é expressa por $\frac{\overline{F^{\prime} P f}}{F P f}$.

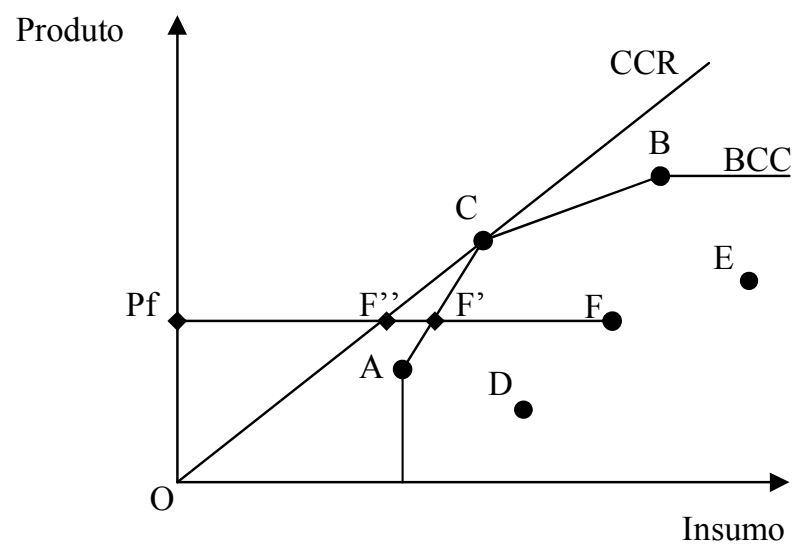

Gráfico 7 - Modelos CCR-I e BCC-I

Orientados aos produtos, os modelos CCR-O e BCC-O projetam, respectivamente, as DMUs virtuais da $\mathrm{DMU}_{\mathrm{F}}$ nos pontos F' e F', observadas no Gráfico 8. 


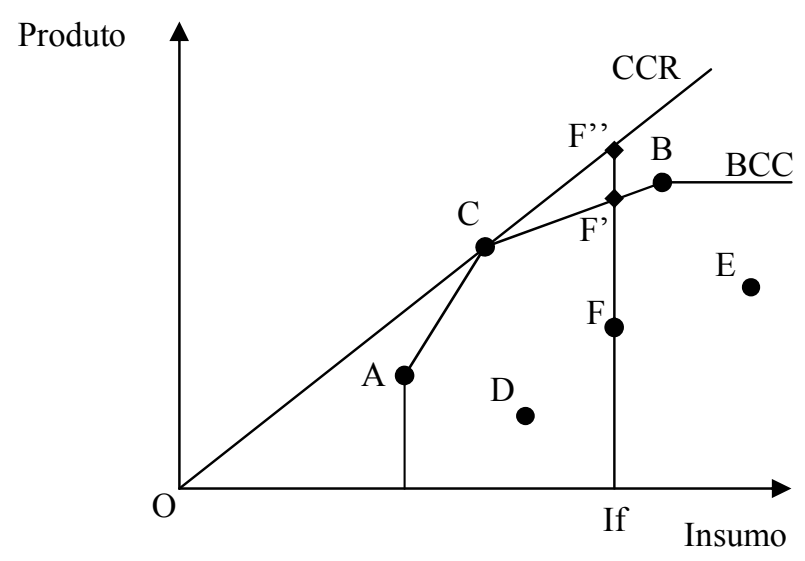

Gráfico 8 - Modelos CCR-O e BCC-O

O valor representativo If é fixado e os níveis de eficiência são expressos pelos segmentos $\frac{\overline{F I f}}{F^{\prime \prime} I f}$ (modelo CCR-O) e $\frac{\overline{F I f}}{F^{\prime} I f}$ (modelo BCC-O).

A única DMU que pode ser considerada eficiente em ambos os modelos na situação exemplificada pelo Gráfico 8 é a DMU . As DMUs A e B são consideradas eficientes apenas no modelo BCC, pois no modelo CCR elas não estão sobre a fronteira eficiente. Dependendo da orientação do modelo, os benchmarks são estabelecidos e podem servir de referência para os gestores das DMUs ineficientes adotarem medidas operacionais para a melhoria do desempenho.

\subsubsection{Fronteira invertida}

Uma das características da modelagem DEA é a possibilidade de várias DMUs serem classificadas como eficientes considerando-se apenas uma ou poucas variáveis em que estas possuem vantagens perante as demais, reduzindo o poder discriminatório no conjunto avaliado (COOPER et al., 2007). Muitas variáveis podem implicar na ocorrência de muitas DMUs eficientes.

Inicialmente proposta por Yamada et al. (1994) para identificar e segregar as DMUs ineficientes sob uma perspectiva oposta, através do cálculo de uma fronteira de ineficiência produtiva, a chamada fronteira invertida também vem sendo utilizada para conhecer não 
somente as DMUs mais ineficientes, mas também para favorecer a discriminação entre as próprias DMUs consideradas eficientes, conforme aplicação encontrada em Leta et al. (2005).

Para se avaliar as DMUs sob o enfoque pessimista, a relação original de eficiência é invertida ao se considerar os insumos como produtos e os produtos como insumos. No Gráfico 9 podem-se observar as duas fronteiras (eficiente e invertida) para o modelo BCC.

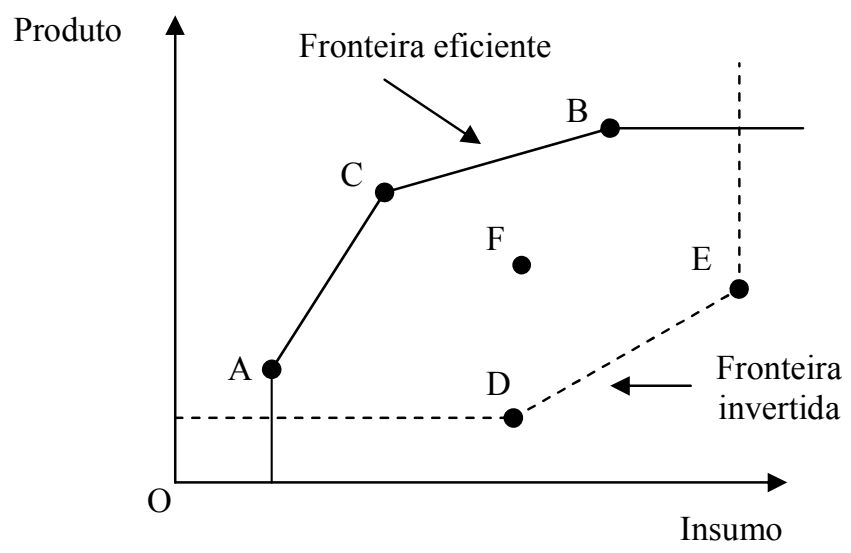

Gráfico 9 - Fronteiras eficiente e invertida

Leta et al. (2005) propuseram o seguinte cálculo aritmético baseado nas fronteiras eficiente (otimista) e invertida (pessimista) para aumentar o poder discriminatório entre as DMUs analisadas:

$$
\text { Eficiência }_{\text {final }}=\frac{\text { Eficiência }_{\text {otimista }}-\text { Eficiência }_{\text {pessimista }}+100}{2}
$$

\subsubsection{Seleção de variáveis}

Conforme Sengupta e Sahoo (2006) e Cunha et al. (2006), há uma tendência de que muitas DMUs se situem na fronteira eficiente perante o aumento da quantidade de variáveis consideradas na DEA e uma maneira de se contornar esse problema é a redução do número de variáveis usadas no modelo de análise. A seleção das variáveis, portanto, é uma das mais importantes fases no processo de análise de desempenho. Ainda que diferentes conjuntos de variáveis conduzam a diferentes resultados, pondera-se que esse fato não é uma fragilidade da 
DEA, mas apenas uma característica de sua aplicação que permite analisar o mesmo problema sob diferentes perspectivas.

Senra et al. (2007) recomendam que, inicialmente, seja formado um conjunto amplo de variáveis relacionadas ao objeto estudado, preferencialmente, com a participação de técnicos e especialistas da área. Para Lins e Angulo Meza (2000), quando os casos possuem poucas variáveis e muitas DMUs, não se justifica a preocupação em utilizar técnicas de seleção de variáveis, pois o conjunto pré-selecionado não deverá prejudicar significativamente o modelo DEA. Todavia, é benéfico para o processo de análise a redução da proporção entre o número de DMUs e a quantidade de variáveis. Gomes e Mangabeira (2004) destacam a necessidade de que ao menos a quantidade de DMUs seja o triplo da quantidade total de variáveis. Gonzalez-Araya (2003) sugere, de maneira mais conservadora, que existam, no mínimo, 4 DMUs para cada variável presente no problema. Dyson et al. (2001) afirmam que, para haver um nível satisfatório de discriminação entre as unidades estudadas no modelo DEA, o número de DMUs deve superar, em duas vezes, o produto da quantidade de inputs por outputs.

Na literatura consultada sobre DEA, predominantemente as variáveis foram escolhidas por critérios relacionados à conveniência do pesquisador e à disponibilidade de dados, sem o uso específico de ferramentas estatísticas para a respectiva escolha. Dentre os trabalhos que utilizaram critérios de seleção com embasamento estatístico, destacam-se os seguintes métodos: correlação (NORMAN; STOCKER, 1991), I-O Stepwise (LINS; MOREIRA, 1999), Multicritério (SOARES DE MELLO, 2002).

Como salientam Senra et al. (2007, p. 193):

Neste contexto, os métodos de seleção de variáveis devem ser vistos como instrumentos de auxílio à decisão, que orientarão a escolha final. Esta não deve ficar presa ao resultado de um modelo matemático, por mais sofisticado que seja. Sempre deve ser feita em conjunto pelos agentes de decisão, especialistas e analistas, que poderão (ou não) usar um método de seleção como ferramenta.

\subsection{Restrição orçamentária fraca - Soft Budget Constraint}

Proposto inicialmente por Kornai $(1980,1986)$ ao analisar aspectos relacionados à eficiência de unidades econômicas de países que migravam do sistema socialista para a economia de 
mercado, o conceito de Soft Budget Constraint (SBC) passou a ser utilizado na literatura científica de maneira mais ampla, não apenas para explorar as questões relacionadas à transição de sistemas econômicos socialistas, mas também para explorar situações presentes em organizações do próprio contexto capitalista.

A fundamentação teórica da SBC é microeconômica e caracteriza-se quando a relação entre as receitas e despesas de um agente econômico é relaxada, porque a diferença entre o excesso de despesas diante das receitas será suprida, integral ou parcialmente, por alguma outra instituição, tipicamente pelo Estado paternalista (KORNAI, 1986). Quanto maior a probabilidade subjetiva de que o déficit financeiro seja coberto por uma assistência externa, maior será o relaxamento das restrições orçamentárias.

Em situação oposta, a Hard Budget Constraint (HBC) é caracterizada quando, diante das dificuldades geradas pelo fluxo de despesas maior que o de receitas, não se pode contar com o auxílio de agentes externos para cobrir os problemas financeiros e a organização é obrigada a reduzir ou encerrar suas atividades operacionais no longo prazo considerando déficits recorrentes.

Os principais caminhos para se enfraquecer as restrições orçamentárias, conforme Maskin (1999) e Kornai et al. (2003), estão vinculados a: subsídios, benefícios fiscais, favorecimento de crédito e suporte indireto (como, por exemplo, a regulação governamental para proteger determinados segmentos industriais da concorrência externa). Esses elementos não são mutuamente excludentes nem exaustivos, podendo coexistir simultaneamente em uma mesma organização, assim como podem existir outras formas para se estimular a SBC.

A contrapartida desse enfraquecimento é percebida, muitas vezes, pela perda de eficiência e, sob determinadas condições, ainda pode gerar excesso de demanda (LI; LIANG 1998).

\subsubsection{Síndrome da Soft Budget Constraint}

Maskin e $\mathrm{Xu}$ (2001) comentaram sobre as possíveis causas para a síndrome da SBC, entendida como um conjunto de sintomas que caracteriza o enfraquecimento das restrições orçamentárias. Os autores relacionaram tais causas às implicações políticas, sociais e econômicas que poderiam ocorrer diante da falência de algumas organizações e 
exemplificaram com as consequências decorrentes da quebra de bancos, as quais poderiam contrariar interesses dos governantes e provocar efeitos nocivos em toda a sociedade. Kornai et al. (2003) reafirmaram que a síndrome da SBC se aplica claramente aos bancos e a outros intermediários financeiros, em que os agentes em dificuldade são suportados para continuarem operando e, posteriormente, podendo ser adquiridos por concorrentes. A década de 1990 presenciou diversas intervenções socorristas com recursos públicos ao setor bancário em todo o mundo, particularmente na crise asiática (CANUTO, 2000). No Brasil, em 1995, o Programa de Estímulo à Reestruturação e ao Fortalecimento do Sistema Financeiro Nacional - PROER - teve a finalidade de recuperar instituições financeiras em dificuldades para evitar um colapso sistêmico.

Nas últimas décadas, entretanto, nenhum movimento socorrista foi tão intenso quanto o verificado na crise econômica deflagrada pelos problemas de crédito imobiliário nos Estados Unidos em 2008, com graves repercussões devido à escassez creditícia no mercado financeiro mundial. Nessa crise, foram aprovados diversos pacotes de auxílio e saneamento a instituições financeiras e empresas privadas com problemas de solvência em diferentes países. Segundo o Fundo Monetário Internacional, em seu Relatório sobre a Estabilidade Financeira Mundial (FMI, 2009), o custo total da crise financeira mundial superará US\$ 4,1 trilhões, somando-se as perdas relacionadas à desvalorização de ativos financeiros americanos (US\$ 2,7 trilhões), europeus (US\$ 1,2 trilhão) e japoneses (US\$ 149 bilhões).

Suportes financeiros do Estado são comuns para diversos tipos de organizações sem fins lucrativos, como hospitais, escolas e universidades que gastam mais do que recebem (KORNAI et al., 2003). Duggan (2000), ao analisar hospitais com e sem fins lucrativos, identificou a síndrome da $\mathrm{SBC}$ nesses últimos, sugerindo que o aumento de gastos públicos em tais entidades não aperfeiçoou os resultados obtidos junto ao público atendido.

Raiser (1994) afirma que o relaxamento da disciplina financeira por parte dos agentes beneficiados pelo auxílio governamental sobrecarrega o próprio Estado, cujo comportamento paternalista o leva a promover gastos socorristas.

Para Kornai (1986), a pressão popular para a adoção de políticas redistributivas por parte dos governantes, objetivando a redução de desigualdades socioeconômicas, pode estimular o 
aumento de gastos públicos e a transferência de recursos a entidades e programas sociais que apresentem ineficiência alocativa de seus próprios recursos.

Por outro lado, como observam Qian e Roland (1998), um sistema de gestão pública baseado em um orçamento perfeitamente rígido (hard budget constraint) implica na prática de ações constrangedoras e impopulares, tais como a prisão e a captura dos bens do devedor. Para esses autores, provavelmente a maioria da população de todos os países queira afastar-se dos pontos extremos: nem o relaxamento, que prejudica significativamente a alocação eficiente dos recursos da sociedade, nem a rigidez orçamentária, que pode impedir a continuidade de serviços e políticas sociais relevantes para a melhoria da situação do povo. Dessa maneira, dever-se-ia buscar a restrição orçamentária mais rígida para o bem da eficiência, sem (ou com poucas) consequências ao bem-estar da população. Há, portanto, situações de escolhas entre os tipos de consequências geradas pelo enrijecimento ou relaxamento das restrições orçamentárias. 


\section{TRAJETÓRIA DA PESQUISA}

Muito mais do que a simples aplicação de conhecimentos sistematizados caracterizada pela tecnologia, a ciência, como geradora de conhecimentos, contribui para a libertação do indivíduo da mesmice alienante, pois o faz refletir, constantemente, sobre causas e efeitos. A ciência não se propõe a ser a guardiã da verdade, conforme já afirmou Popper (2001), mas procura ser aquela que oferece elementos racionais para se refutar a falsidade. Seguem-se, disciplinadamente, regras de pensamento, mas estimula-se, ao mesmo tempo, a inovação e o assombro. Ainda que não se confirmem as expectativas iniciais dos pesquisadores, os resultados devem ser divulgados e, novamente, testados por outros cientistas, sempre visando à apreensão da realidade em detrimento de conviç̧ões pessoais.

Opiniões baseadas em ideias pré-concebidas ou sobre um suposto senso comum não fazem parte do método científico. Diante de fenômenos ainda pouco estudados sob o rigor metodológico, o desafio natural do cientista é enfrentar, muitas vezes, o ceticismo infundado de opiniões emitidas no próprio ambiente acadêmico.

Apesar da relevância social e científica, uma das maiores dificuldades enfrentadas pelas pesquisas sobre organizações não-governamentais sem fins lucrativos é a indisponibilidade de dados organizados, exigindo a construção e adaptação de ferramentas específicas para a coleta, processamento e análise dos dados.

Esta pesquisa foi planejada e desenvolvida sob o espírito crítico e desafiador que move a ciência.

\subsection{Considerações iniciais}

De origem grega, a palavra método (methodus) representa uma trajetória (ou via) para se chegar a algum ponto desejado. Sob a perspectiva científica, portanto, o método é o caminho percorrido pelo pesquisador para atingir o conhecimento científico. 
A metodologia, por sua vez, pode ser definida como "[...] o estudo e a avaliação dos diversos métodos, com o propósito de identificar possibilidades e limitações no âmbito de sua aplicação no processo de pesquisa científica" (DIEHL; TATIM, 2004, p. 27).

A investigação de qualquer fenômeno demanda métodos e instrumentos adequados às consecutivas análise e compreensão do objeto estudado. Nesse sentido, a pesquisa de fenômenos sociais, em que o ser humano é o agente principal, enfrenta questionamentos sobre a validade científica da aplicação de métodos utilizados em outros estudos, por exemplo, cujos objetos estão no âmbito das ciências naturais.

Ladriére (1991) levanta problemas relevantes decorrentes da tentativa de objetivação do agente humano para se permitir o tratamento sistemático do fenômeno, tal qual é realizado pelas ciências da natureza. Nesse caso, desconsiderar-se-iam as significações, as finalidades, as intenções e os valores que estão intrinsecamente relacionados no indivíduo para tratá-lo como unidade comparável e válida num determinado modelo. Por outro lado, ao se optar pela tentativa de compreensão do agente humano e de sua complexidade, a subjetividade inerente nessa abordagem impediria o tratamento científico de diferentes aspectos do fenômeno, valorizando a particularização e diferenciação do ser. Esse conflito liga-se, assim, à discussão da cientificidade das ciências sociais frente às ciências da natureza, considerando-se a concepção científica da realidade em que os seres humanos são, ao mesmo tempo, agentes e intérpretes.

Bachelard (1996) destaca a perspectiva da historicidade na construção do conhecimento científico, aliado a um processo de aproximação do saber sobre as relações presentes nos fenômenos mediante a adoção de referências para a caracterização da própria ciência. Concomitantemente, a ciência constrói, reconstrói, aperfeiçoa e abandona teorias e critérios num constante repensar crítico. Corroborando Bachelard, Ladriére destaca o processo pelo qual a ciência se constitui em seu devir histórico, em que "[...] a cientificidade representa uma idéia reguladora, não um modelo determinado, considerado elaborado de uma vez por todas ou, pelo menos, em vias de elaboração.” (LADRIÉRE, 1991, p.12). 


\subsection{Polos metodológicos}

Bruyne et al. (1991) propuseram a interação de aspectos particulares da mesma realidade para a produção de discursos e de práticas científicas, objetivando produzir e expressar o conhecimento sobre algum fenômeno em estudo. Segundo os autores, toda pesquisa possui quatro polos paradigmáticos (epistemológico, teórico, morfológico e técnico) relacionados entre si de maneira intrínseca e que definem um campo metodológico capaz de garantir a cientificidade da investigação.

A Ilustração 3 apresenta o modelo quadripolar de pesquisa.

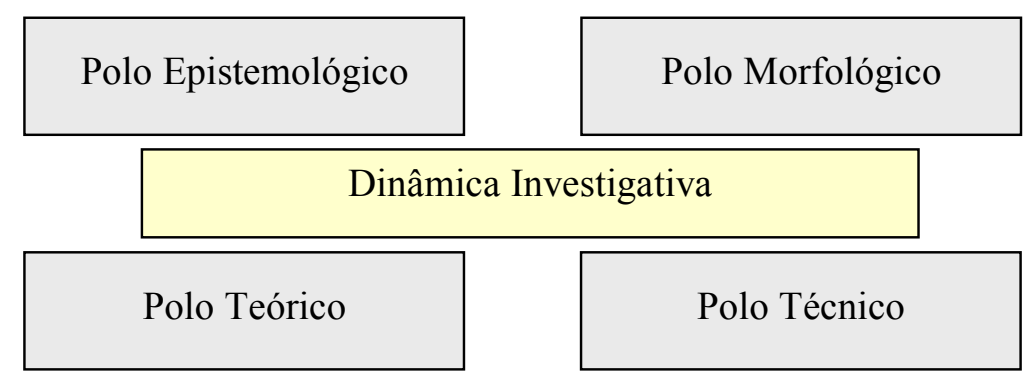

Ilustração 3 - Modelo quadripolar de pesquisa

\subsubsection{Polo epistemológico}

Epistemologia é um termo relativamente recente, criado no século XIX, cujo significado etimológico relaciona-se ao discurso (logos) sobre a ciência (episteme). Segundo Japiassu (1992), trata-se de disciplina ainda em construção e que não tem um conteúdo definitivo, o qual é empregado de forma bastante flexível. Vale-se da filosofia para lançar um olhar crítico sobre a ciência. De maneira peculiar, situa-se entre a própria filosofia e a ciência formal, interagindo com ambas. É passível de verificação se a origem de sua função não está na própria filosofia clássica, servindo-se de nomes diferentes para representar a mesma atitude crítica (JAPIASSU, 1992).

Para Popper (2001), a ciência apresenta um dinamismo semelhante ao evolucionismo darwiniano, segregando as teorias que subsistem daquelas que são refutadas, mas essa subsistência é temporária até o aparecimento de outra com melhor poder explicativo e 
preditivo da realidade. Dessa maneira, coloca-se em xeque a existência de um fundamento único para a ciência.

O conhecimento pode ser entendido como um processo e não como algo individualizado e passível de aquisição (BACHELARD, 1996). Sendo um processo, apresenta estágios distintos, passando de um conhecimento anterior para um posterior. A tarefa da epistemologia consiste em conhecer esse devir e em analisar todas as etapas de sua estruturação, para se chegar, conforme Japiassu (1992), a uma posição popperiana de um conhecimento provisório, inacabado e relativo. Assim, seu objeto de estudo é a ciência em vias de se fazer, desde sua origem até sua estruturação progressiva.

Nesse sentido, a caracterização epistemológica de um trabalho acadêmico se verifica pela presença e pela validade de elementos de cientificidade e de produção de conhecimento em determinada área. O polo epistemológico enuncia, explicitamente, a problemática e as questões de pesquisa, as quais exigem respostas objetivas obtidas ao final do caminho investigativo.

Com relação a esse polo, o presente trabalho persegue aquilo que Kuhn (1987) designou de "a melhor aproximação da verdade", ainda que limitado a determinado grupo (no caso, as ILPIs) e em tempo definido (período 2008-2009), sem a pretensão da generalização dos resultados obtidos, mas baseando-se em dados objetivos para estimular a reflexão crítica sobre a realidade.

Independentemente da aceitação transitória ou da refutação das hipóteses iniciais, o produto científico é apresentado como conhecimento, aumentando a compreensão do fenômeno estudado, e contribui para futuros e necessários questionamentos sobre a realidade.

\subsubsection{Polo teórico}

O polo teórico oferece os princípios e leis que permitem reconhecer e abordar o objeto estudado em determinado contexto. Segundo Bruyne et al. (1991, p. 102), a teoria fornece "[...] um corpo de enunciados sistemático e autônomo, de uma linguagem com suas regras e dinâmicas próprias que lhe asseguram um caráter de fecundidade.” É neste polo que as 
hipóteses, entendidas como suposições, são elaboradas e os conceitos operacionais são definidos.

Neste trabalho, a elaboração das suas questões e hipóteses direcionadoras, assim como os conceitos utilizados em sua construção, priorizaram a postura positiva, a qual Friedman (1953) caracterizou pela ação de descrever como as coisas são, contrastando com a ótica normativa que se propõe a apontar como as coisas deveriam ser.

Para Patton (1980), o positivismo busca os fatos de um fenômeno, desconsiderando os aspectos subjetivos dos indivíduos.

Autores como Wildemuth (1993) e Cassel e Symon (1994) entendem que, no positivismo, se assume a existência de uma verdade objetiva passível de revelação pelo método científíco, cujo enfoque é o relacionamento sistemático de variáveis.

Hendriksen e Van Breda (1999), ao discutirem os aspectos teóricos da Contabilidade, comentaram sobre a associação entre teorias positivas e normativas com os raciocínios indutivo e dedutivo. O raciocínio indutivo é caracterizado pela formulação de conclusões gerais com base em observações específicas, ou seja, parte-se do particular para o geral. A abordagem dedutiva, por sua vez, parte de princípios aceitos como verdadeiros para se chegar a conclusões formais em que a razão é capaz de levar ao conhecimento.

As teorias indutivas, por sua natureza, são geralmente positivas; mas não decorre daí que as teorias dedutivas sejam necessariamente normativas. Pode-se partir de generalizações do que se acha existir e obter daí deduções específicas que visam ser completamente descritivas. (HENDRIKSEN; VAN BREDA, 1999, p.30).

Entretanto, Iudícibus (2000, p.27), ao comentar sobre a teoria contábil, alerta que não existe raciocínio indutivo puro, visto que esse sempre contará, implicitamente, com o raciocínio dedutivo, ao menos no que se refere à escolha do que observar, pois se evidenciam "noções previamente concebidas do que é ou não relevante". Esse alerta baseia-se na crítica de Popper (2001) de que a indução também exige o apriorismo, com a agravante de justificar-se metodologicamente em si mesma, provocando uma petição de princípio. 
Popper (2001) também critica o indutivismo ao afirmar que tal caminho não se justifica diante do salto cognitivo exigido para se migrar de algumas observações para a posterior generalização. No clássico exemplo popperiano tem-se que, para se sustentar a argumentação de que todos os cisnes são brancos, seria necessário observar toda a população de cisnes, tanto no presente, quanto no passado e no futuro, porque a soma das observações realizadas representa, apenas, um número finito, mas o enunciado geral pretende ser infinito. Para o estabelecimento da base lógica da argumentação científica, Popper propôs o método hipotético-dedutivo.

Conforme Gil (1999), no raciocínio hipotético-dedutivo:

O cientista, através de uma combinação de observação cuidadosa, hábeis antecipações e intuição científica, alcança um conjunto de postulados que governam os fenômenos pelos quais está interessado, daí deduz ele as conseqüências por meio de experimentação e, dessa maneira, refuta os postulados, substituindo-os, quando necessário por outros e assim prossegue. (GIL, 1999, p.30)

A Ilustração 4 apresenta a sequência utilizada pelo método hipotético-dedutivo.

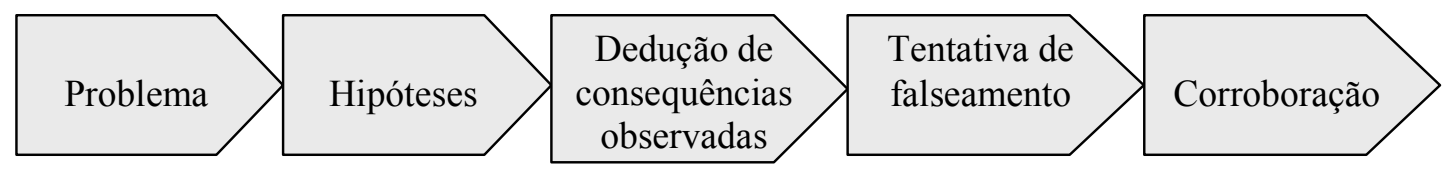

\section{Ilustração 4 - Sequência hipotética-dedutiva}

As etapas do método hipotético-dedutivo partem de teorias existentes, capazes de permitirem a detecção de um problema, lacuna ou contradição teórica, para a posterior formulação de hipóteses. As respectivas conjecturas podem predizer situações ou fatos se forem verdadeiras, mas para essa confirmação devem ser realizados testes objetivos. Os resultados obtidos dos testes são, por fim, confrontados com as hipóteses iniciais, corroborando-as ou refutando-as.

Contrastando a associação de Hendriksen e Van Breda (1999) entre teorias positivas e o indutivismo, Patton (1980) afirma que uma pesquisa puramente positivista segue o paradigma hipotético-dedutivo.

O programa de pesquisa utilizado neste trabalho se aproxima da investigação em superfície, pois, conforme caracteriza Theóphilo (2004, p. 104), tal programa “[...] compreende o 
aumento de conhecimento rotineiro, assim considerado aquele que, baseado nas crenças existentes, é voltado ao aprimoramento de teorias tradicionalmente aceitas dentro de uma comunidade científica."

Theóphilo (2004) nota que há uma relação direta entre os trabalhos de postura positiva e investigação em superfície, assim como o oposto também é verdadeiro, há uma relação direta entre trabalhos normativos e em profundidade, caracterizados pela introdução de novos conceitos e proposição de ideias a partir de novas visões e perspectivas. Ao analisar a mudança de perfil da produção acadêmica no Programa de Pós-Graduação em Contabilidade da Universidade de São Paulo, Theóphilo (2004, p. 165) também comenta que “[...] a reversão da predominância de trabalhos normativos em profundidade foi importante, pois essa opção levava a certo distanciamento entre a investigação científica e o mundo real, denotando um excesso especulativo."

\subsubsection{Polo morfológico}

Conforme Bruyne et al. (1991), o polo morfológico representa o plano de objetivação da problemática, ao organizar os fenômenos e, simultaneamente, representar e estruturar os objetos científicos e sua rede de relações. A formalização da pesquisa ocorre pela exposição metódica de fatos, conceitos, teses, proposições etc., para a articulação do sentido das teorias úteis ao próprio trabalho científico.

A estratégia utilizada neste trabalho para se conhecer o fenômeno estudado baseia-se na observação empírica e na mensuração quantitativa das variáveis consideradas. Tal abordagem, conforme Martins (1994), é caracterizada como empírico-analítica. Nesta pesquisa, as variáveis construídas e apresentadas são: insumos, produtos, eficiência produtiva, natureza das fontes de receita e nível de disclosure das instituições filantrópicas de longa permanência para idosos.

Este trabalho é, predominantemente, quantitativo, pois atende à caracterização de Richardson $(1999$, p. 47) para tal modalidade, ao “[...] empregar a quantificação tanto nas modalidades de coleta de dados, quanto no tratamento deles por meio de técnicas estatísticas, desde as mais simples [...] às mais complexas." 
Com relação ao seu objetivo, classifica-se como descritiva, pois tem como foco principal “[...] descrever as características de determinada população ou fenômeno, ou ainda o estabelecimento de relações entre as variáveis." (GIL, 1999, p. 35).

\subsubsection{Polo técnico}

Os procedimentos de coleta de dados e sua transformação em informações seguiram um estudo teórico-empírico. Trabalhos com essa característica, para Rudio (2002), são guiados pelo propósito de conhecer a realidade pela experiência, em que a realidade empírica se revela nos fatos e precisam de uma base teórica como referência. Na classificação de Theóphilo (2004) sobre os tipos de estudos teórico-empíricos, este trabalho enquadra-se naqueles considerados quase-experimentos, uma vez que se ampara em fontes documentais, é conduzido pelo propósito de testes de hipóteses e busca apresentar, efetivamente, resultados em suas conclusões.

\subsection{Plano amostral}

O plano amostral deste trabalho foi elaborado em função dos objetivos definidos na pesquisa e consistiu, basicamente, na delimitação do ambiente para a realização do estudo e na definição específica dos atributos da amostra. Nesse plano, inicialmente identificou-se o universo a que se refere o trabalho, assim como a população pesquisada e a respectiva unidade amostral (que representa o objeto sobre o qual são observadas as características quantitativas e qualitativas da população e em que se farão medidas de interesse à pesquisa).

Dependendo dos procedimentos a serem utilizados para a coleta de dados, Demo (1987) e Magalhães (2005) recomendam que no plano amostral sejam definidos os perfis desejados dos possíveis respondentes e a extensão da área geográfica onde se fará o estudo.

Nesta pesquisa, a população estudada é discreta e finita, formada pelas instituições filantrópicas paulistas de longa permanência para idosos. 
Para conhecer a quantidade de organizações filantrópicas brasileiras, voltadas à internação de idosos, consultou-se o cadastro eletrônico das entidades filantrópicas registradas no Ministério do Desenvolvimento Social em julho/2008.

A composição do grupo estudado pautou-se pelos critérios apresentados a seguir:

a) Registro no banco eletrônico de dados cadastrais do MDS, o qual contém a relação das entidades filantrópicas isentas de contribuição previdenciária e com o registro CEBAS válido.

b) Sede no Estado de São Paulo/SP.

No mês-base, em março de 2009, foram identificadas 212 instituições relacionadas a serviços asilares ou à assistência de longa permanência a idosos no Brasil que possuíam o CEBAS válido. No Estado de São Paulo, 78 entidades encontravam-se no cadastro eletrônico do CNAS, mas somente 59 estavam devidamente regularizadas, enquanto 19 organizações encontravam-se em processo de regularização ou tiveram o certificado cancelado.

Para Richardson (1999), cabe ao pesquisador analisar as condições ambientais e as limitações de recursos para optar entre a amostra aleatória e a intencional. A amostra aleatória obedece a critérios estatísticos que apresentam poder de generalização, enquanto que na intencional (ou por conveniência) os resultados são limitados ao grupo observado. Nesta pesquisa, todas as 59 ILPIs paulistas com o CEBAS válido (ver Apêndice 1) foram contatadas, objetivando-se o estudo das ILPIs oficialmente filantrópicas da área geográfica do Estado de São Paulo.

A amostra foi formada por conveniência com as 42 entidades (71,2\% das organizações com a certificação de filantropia válida) que forneceram todos os dados solicitados.

A delimitação temporal da pesquisa refere-se ao período 2008-2009, considerando-se as informações obrigatórias referentes ao período de 2008 que as ILPI deveriam disponibilizar aos órgãos fiscalizadores no início de 2009, informações essas que compõem os indicadores de insumos e produtos utilizados neste estudo. Os elementos do plano amostral são apresentados no Quadro 5. 
Quadro 5 - Elementos do plano amostral

\begin{tabular}{|c|c|}
\hline Elementos & Descrição \\
\hline População & $\begin{array}{c}\text { Instituições filantrópicas paulistas de longa } \\
\text { permanência para idosos com o CEBAS válido }\end{array}$ \\
\hline Universo & 59 organizações \\
\hline Seleção pretendida & 59 organizações (100,0\%) \\
\hline Seleção intencional & 42 organizações (71,2\%) \\
\hline Respondentes & Gestores e outros responsáveis pelas ILPI \\
filantrópicas paulistas
\end{tabular}

\subsection{Mensuração do nível da eficiência produtiva das ILPIs}

Para o cálculo da eficiência produtiva através da Análise Envoltória de Dados, considerou-se cada organização filantrópica selecionada como uma DMU (Decision Making Unit), ou seja, como uma unidade tomadora de decisões para transformar insumos em produtos. Respeitando-se a necessidade de confidencialidade, conforme condição solicitada diretamente por 4 das organizações pesquisadas, as DMUs foram numeradas aleatoriamente, sem guardar relação direta com a ordem alfabética das entidades selecionadas nem com as respectivas cidades de origem.

Optou-se pela utilização do modelo DEA orientado aos insumos a fim de se priorizar a identificação de DMUs com consumo de recursos proporcionalmente maior que as unidades classificadas como mais eficientes, objetivando-se, dessa maneira, apontar alvos para a minimização da quantidade necessária de inputs para um mesmo volume de outputs. Essa escolha de orientação fundamenta-se no fato de que o limite máximo dos valores dos indicadores utilizados como referência dos produtos neste trabalho é igual a 100\%, portanto, se o modelo fosse orientado aos produtos, os resultados poderiam apontar que algumas DMUs, dados determinados níveis de insumos, deveriam atingir valores superiores a $100 \%$ para serem consideradas eficientes, situação essa assumida como impraticável.

Considerando-se que as DMUs podem apresentar variações de retorno de escala, adotou-se o modelo VRS (Variable Return to Scale), desenvolvido por Banker, Charnes e Cooper (1984). 
Conforme Soares de Mello et al. (2005), o modelo VRS (também denominado BCC) pressupõe o axioma da convexidade em substituição ao axioma da proporcionalidade entre insumos e produtos utilizado pelo modelo CRS (Constant Return to Scale). Uma vez que considera a convexidade da fronteira de produção eficiente, o modelo BCC aceita que DMUs que operam com baixos valores de insumos obtenham retornos crescentes de escala, assim como as que operam com altos valores obtenham retornos decrescentes de escala. $\mathrm{O}$ modelo DEA-VRS orientado a input é apresentado a seguir:

$$
\operatorname{Min} \theta_{0}
$$

Sujeito a:

$$
\begin{gathered}
\theta x_{i 0}-\sum_{k=1}^{n} x_{i k} \lambda_{k} \geq 0 \\
-y_{j 0}+\sum_{k=1}^{n} y_{j k} \lambda_{k} \geq 0 \\
\sum_{k=1}^{n} \lambda_{k}=1 \\
k=1,2, \ldots, n ; \quad i=1,2, \ldots, m ; j=1,2, \ldots, r \\
\lambda_{k} \geq 0, \forall k
\end{gathered}
$$

Em que:

$\theta_{0}$ é a eficiência da $\mathrm{DMU}_{0}$;

$x_{i 0}$ é a quantidade de insumos $i$ utilizada pela $\mathrm{DMU}_{0}$;

$x_{i k}$ é a quantidade de insumos $i$ utilizada pela $\mathrm{DMU}_{k}$;

$y_{j 0}$ é a quantidade de produtos $j$ gerada pela $\mathrm{DMU}_{0}$;

$y_{j k}$ é a quantidade de produtos $j$ gerada pela $\mathrm{DMU}_{k}$;

$\lambda_{k}$ é a k-ésima coordenada da $\mathrm{DMU}_{0}$ em uma base formada pelas DMUs de referência.

O dual de (6) proporciona o modelo DEA-VRS orientado a input pelo método dos multiplicadores, conforme apresentado em (7). Destaca-se que $w *$ é uma variável dual 
associada à condição $\sum_{k=1}^{n} \lambda_{k}=1$ e é interpretada como fator de escala (SOARES DE MELO et al., 2005).

$$
\operatorname{Max} h_{0}=\sum_{j=1}^{r} w_{j} y_{j 0}-w_{*}
$$

Sujeito a:

$$
\begin{gathered}
\sum_{i=1}^{m} v_{i} x_{i 0}=1 \\
\sum_{j=1}^{r} w_{j} y_{j k}-\sum_{i=1}^{m} v_{i} x_{i k}-w_{*} \leq 0 \\
k=1,2, \ldots, n ; i=1,2, \ldots, m ; j=1,2, \ldots, r \\
v_{i}, w_{j} \geq 0, \forall i, j \\
\mathcal{w}_{*} \in \mathfrak{R}
\end{gathered}
$$

$h_{0}$ é a eficiência da $\mathrm{DMU}_{0}$;

$w_{j}$ é o peso associado ao produto $j$;

$y_{j 0}$ é a quantidade de produtos $j$ gerada pela $\mathrm{DMU}_{0}$;

$y_{j k}$ é a quantidade de produtos $j$ gerada pela $\mathrm{DMU}_{k}$;

$v_{i}$ é o peso associado ao insumo $i$;

$x_{i 0}$ é a quantidade de insumos $i$ utilizada pela $\mathrm{DMU}_{0}$;

$x_{i k}$ é a quantidade de insumos $i$ utilizada pela $\mathrm{DMU}_{k}$;

$n$ é a quantidade de DMUs;

$m$ é a quantidade de variáveis relacionadas aos insumos;

$r$ é a quantidade de variáveis relacionadas aos produtos.

\subsubsection{Construção do indicador de eficiência}

Considerando-se a relação básica de eficiência (outputs/inputs), qualquer indicador nesse sentido deve conter elementos representativos dos produtos oferecidos em determinado período aos respectivos consumidores ou usuários, assim como se deve ter em conta os insumos utilizados - consumidos ou transformados - nesse processo produtivo. 
Para se levantar os indicadores para o cálculo de eficiência das organizações do Terceiro Setor voltadas ao atendimento de idosos, procurou-se conhecer, inicialmente, as atividades e o contexto em que tais entidades operam, a fim de responder as seguintes questões econômicas clássicas: O que fazem? Como? Para quem? Com quais recursos?

Após a caracterização e entendimento do ambiente operacional, foi realizada uma análise preliminar das potenciais variáveis para a posterior utilização na modelagem da DEA. Segundo Senra et al. (2007, p. 192), “[...] a análise prévia de possíveis conjuntos de variáveis é uma etapa fundamental, a ser feita conjuntamente por decisores, especialistas e analistas. Só após esta escolha prévia é que tem sentido pensar-se em métodos de seleção.”

\subsubsection{Indicadores relacionados aos produtos}

Pautando-se pela legislação vigente, os produtos gerados pelas ILPIs são padronizados com relação às suas características básicas para o atendimento de seus usuários, gerando uma situação de homogeneização dos serviços essenciais e permitindo a avaliação comparativa entre as entidades sobre os mesmos aspectos. Os produtos estão, indissociavelmente, vinculados à missão, aos objetivos sociais e aos resultados das ILPIs.

Dessa maneira, os indicadores de outputs foram selecionados baseando-se nos critérios legais para a avaliação do desempenho das organizações, conforme já apresentado na seção 2.3.1, no Quadro 3. Como os indicadores expressam uma relação em que, quanto menores forem os seus valores, melhor será o desempenho operacional da entidade (por exemplo, o ideal seria uma taxa de ocorrência de doenças igual a $0 \%$ de casos), fez-se necessária a adequação desses indicadores para expressarem a relação inversa de que, quanto maiores, melhor o resultado, em termos de outputs. Nesse sentido, para se trabalhar operacionalmente as variáveis de produtos na relação output/input, considerou-se, para esta pesquisa, a diferença entre os indicadores básicos informados pela entidade e o valor de $100 \%$. Dessa maneira, se alguma DMU apresentar uma taxa, por exemplo, igual a 3,1\% de casos de desnutrição em seus internos, então o indicador específico de output considerado para o modelo DEA será de: $100 \%-3,1 \%=96,9 \%$. 
Quadro 6 - Variáveis relacionadas aos produtos

\begin{tabular}{|c|r|c|}
\hline Variáveis & Indicadores & Observações \\
\hline $\mathrm{P}_{1}$ & 1 - Taxa de mortalidade & \multirow{2}{*}{$0 \leq P_{n} \leq 1$} \\
\hline $\mathrm{P}_{2}$ & 1 - Taxa incidência de doença diarreica aguda & \multirow{2}{*}{ quanto maior, melhor } \\
\hline $\mathrm{P}_{3}$ & 1 - Taxa de incidência de escabiose & \\
\hline $\mathrm{P}_{4}$ & 1 - Taxa de incidência de desidratação & \\
\hline $\mathrm{P}_{5}$ & 1 - Taxa de prevalência de úlcera de decúbito & \\
\hline $\mathrm{P}_{6}$ & 1 - Taxa de prevalência de desnutrição & \\
\hline
\end{tabular}

Sob a perspectiva legal, o público atendido é classificado conforme o grau de autonomia para a realização de cuidados pessoais, havendo três níveis de dependência: I, II e III. Alguns produtos ofertados são, portanto, segmentados pelo grau de dependência demonstrado pelo usuário. Logo, as ILPIs apresentam características operacionais decorrentes da composição do próprio público, formado por idosos com maior ou menor grau de dependência por cuidados. Tal situação é relevante para esta pesquisa para se testar se o grau de eficiência pode estar relacionado, significativamente, com a proporção de usuários conforme o nível de dependência.

\subsubsection{Indicadores relacionados aos insumos}

Em sentido amplo, insumos podem ser definidos como recursos consumidos ou a serem consumidos na produção de outros bens e serviços (McGUIGAN et al., 2006). Usando-se um único insumo $\left(\mathrm{x}_{1}\right)$ ou uma combinação de múltiplos insumos $\left(\mathrm{x}_{1}, \mathrm{x}_{2}, \ldots, \mathrm{x}_{\mathrm{n}}\right)$, pode-se expressar matematicamente a função produção Q pela equação a seguir:

$$
Q=f\left(x_{1}, x_{2}, \ldots, x_{n}\right)
$$

Os grupos de insumos mais comuns presentes na literatura econômica relacionam-se ao capital e ao trabalho, dado determinado nível de tecnologia (VARIAN, 2003).

Por capital entende-se o conjunto (ou estoque) de bens econômicos heterogêneos, tais como: máquinas, instrumentos, fábricas, terras, matérias-primas etc., capaz de gerar bens e serviços (RIZZIERI, 1993, p.23). Faz-se relevante a distinção do termo capital, empregado sob a ótica 
econômica, conforme já caracterizado, e sob a ótica contábil. Para Hendriksen e Van Breda (1999, p.174), “[...] os contadores tendem a associar o termo capital ao valor contábil dos títulos possuídos pelos acionistas.”, mas esses autores complementam que capital, sob a perspectiva contábil, poderia ser entendido como o valor total dos recursos pertencentes ou à disposição de uma empresa, incluindo empréstimos, ações e quaisquer outros instrumentos financeiros emitidos pela entidade.

O trabalho pode ser entendido como um fator primário de produção, usualmente medido em horas ou em salário (SAMUELSON; NORDHAUS, 2004).

Simplificadamente, a equação da função produção pode ser expressa pela relação entre capital (K) e trabalho (L) como:

$$
Q=f(K, L)
$$

Também é comum encontrar na bibliografia consultada a utilização dos fatores capital e trabalho como inputs em estudos sobre a mensuração da eficiência produtiva através da DEA, exemplificado pelos trabalhos de Fizel e Nunnikhoven (1993); Ozcan (1995), Favero e Papi (1995), Lansink et al. (2002), Jemric e Vujcic (2002), Holland e Lee (2002), Keh e Shu (2003), Abbotta e Doucouliagos (2003).

Nesta pesquisa, assumiu-se que capital e trabalho são os fatores que contêm as principais variáveis relacionadas aos inputs. Consequentemente, buscou-se a identificação dessas variáveis relacionadas ao consumo e à utilização de recursos pelas instituições em análise.

No extenso levantamento bibliográfico realizado por Seiford (1997) e complementado por Gattoufi et al. (2004), os quais identificaram cerca de 1.200 trabalhos publicados relacionados à DEA produzidos desde os estudos iniciais em 1978 até 2001, 2,6\% (31 trabalhos) analisaram a eficiência de OTS. Em estudos cujos objetivos estavam vinculados à mensuração da eficiência pela DEA em organizações da área de saúde, as variáveis relacionadas ao capital e ao trabalho encontradas com mais frequência na literatura consultada são apresentadas no Quadro 7. 
Quadro 7 - Principais variáveis relacionadas aos insumos na literatura consultada

\begin{tabular}{|c|c|}
\hline Capital & Trabalho \\
\hline $\begin{array}{l}\text { - } \mathrm{n}^{\mathrm{o}} \text { de leitos } \\
\text { - valor do ativo permanente } \\
\text { - área }\left(\mathrm{m}^{2}\right) / \mathrm{n}^{\mathrm{o}} \text { de pacientes } \\
\text { - despesas correntes totais (exceto } \\
\text { relacionadas ao trabalho) }\end{array}$ & $\begin{array}{l}\text { - } \mathrm{n}^{\mathrm{o}} \text { de funcionários (exceto médicos) } \\
\text { - } \mathrm{n}^{\mathrm{o}} \text { de médicos } \\
\text { - } \mathrm{n}^{\mathrm{o}} \text { de enfermeiros } \\
\text { - salário (exceto médicos) } / \mathrm{n}^{\mathrm{o}} \text { pacientes por dia } \\
\text { - salário dos médicos } / \mathrm{n}^{\mathrm{o}} \text { pacientes por dia } \\
\text { - horas consumidas na atividade de arrumação } \\
\text { - horas consumidas na atividade de lavanderia } \\
\text { - horas consumidas na atividade de nutrição } \\
\text { - horas consumidas na atividade de enfermagem } \\
\text { - horas consumidas na atividade médica }\end{array}$ \\
\hline
\end{tabular}

Ao contrário de organizações governamentais e de mercado, as quais contam quase que exclusivamente com uso da mão-de-obra remunerada, as OTS podem ter - e geralmente têm em seus quadros de colaboradores a participação de trabalhadores voluntários para o desenvolvimento de suas atividades operacionais. Conforme Milani Filho et al. (2003), o voluntariado nas entidades filantrópicas paulistanas de assistência social representa $45,1 \%$ do total da quantidade de mão-de-obra, com uma média de 19,3 horas mensais doadas. Diante dessa situação, também é necessário considerar esse contingente não-remunerado nos indicadores de insumos das ILPIs.

Apenas a informação da quantidade de voluntários que estão colaborando com as instituições pode distorcer a comparação direta. Por exemplo, a OTS “A” conta com a presença regular de 10 voluntários que doam, individualmente, 3 horas/semana, em contraste com a OTS "B", a qual conta com 4 voluntários que oferecem, por pessoa, 8 horas/semana. No total, a OTS "B" recebe mais horas voluntárias semanais do que a OTS “A”, mesmo essa última contando com maior número de voluntários. Dessa maneira, supondo não haver diferenças significativas de especialização funcional, a quantidade de horas totais recebidas de mão-de-obra voluntária é uma métrica com maior poder informacional do que a quantidade de voluntários presentes na organização. Essa métrica relaciona-se ao conceito de Full-Time Equivalent, cuja razão expressa a proporção de horas trabalhadas sobre o total máximo de horas que poderiam ser trabalhadas por um colaborador em tempo integral (HOFMARCHER et al., 2005).

\subsubsection{Seleção das variáveis}

Segundo Cooper et al. (2007), quanto maior for a quantidade de variáveis analisadas, maior será a probabilidade de uma DMU situar-se sobre a fronteira e ser considerada eficiente no 
conjunto, pois poderá ocorrer que cada DMU se destaque favoravelmente em, ao menos, uma das variáveis. Assim, para se aumentar o poder discriminatório entre as unidades eficientes e as não-eficientes, é relevante selecionar-se as variáveis com a menor perda de informação possível.

Conforme destacado por Senra et al. (2007), a seleção das variáveis a serem utilizadas no modelo DEA sempre deve ser realizada com a participação de profissionais e especialistas no assunto, independentemente do uso de métodos estatísticos. Seguindo essa recomendação, para esta pesquisa foram realizadas entrevistas individuais com gestores de 5 ILPIs (3 filantrópicas e 2 privadas), seguindo-se um roteiro semiestruturado para a seleção das variáveis relevantes a serem consideradas na coleta de dados. Inicialmente, foram apresentadas aos gestores as variáveis de insumos levantadas na literatura específica envolvida no cálculo de eficiência através da DEA e foi solicitado que classificassem, por grau de relevância e pertinência, quais delas deveriam constar do instrumento para a coleta de dados.

Considerando uma escala com variação de 0 (muito irrelevante) a 5 (muito relevante), a Tabela 11 apresenta o posicionamento dos gestores sobre as variáveis que poderiam influenciar o desempenho da organização:

Tabela 11 - Variáveis relacionadas ao desempenho de ILPIs

\begin{tabular}{|c|c|c|}
\hline & Gestores & \\
\hline Variáveis & A B C D E & média \\
\hline $\mathrm{n}^{\mathrm{o}}$ de leitos & \begin{tabular}{lllll|}
3 & 5 & 5 & 3 & 5 \\
\end{tabular} & 4,2 \\
\hline valor do ativo permanente & \begin{tabular}{lllll|}
4 & 4 & 5 & 3 & 5 \\
\end{tabular} & 4,2 \\
\hline área $(\mathrm{m} 2) / \mathrm{n}^{\circ}$ de pacientes & \begin{tabular}{lllll|}
3 & 2 & 4 & 1 & 3 \\
\end{tabular} & 2,6 \\
\hline $\begin{array}{l}\text { despesas correntes totais (exceto relacionadas ao } \\
\text { trabalho) }\end{array}$ & $\begin{array}{lllll}5 & 5 & 4 & 3 & 5 \\
\end{array}$ & 4,4 \\
\hline$n^{\circ}$ de funcionários (exceto médicos) & \begin{tabular}{lllll|}
5 & 4 & 5 & 3 & 4 \\
\end{tabular} & 4,2 \\
\hline $\mathrm{n}^{\mathrm{o}}$ de médicos & \begin{tabular}{lllll|}
4 & 4 & 5 & 3 & 5 \\
\end{tabular} & 4,2 \\
\hline $\mathrm{n}^{\mathrm{o}}$ de enfermeiros & \begin{tabular}{lllll|}
3 & 5 & 5 & 4 & 5 \\
\end{tabular} & 4,4 \\
\hline salário (exceto médicos) $/ \mathrm{n}^{\circ}$ pacientes por dia & $\begin{array}{lllll}2 & 3 & 4 & 1 & 2 \\
\end{array}$ & 2,4 \\
\hline salário dos médicos $/ \mathrm{n}^{\circ}$ pacientes por dia & $\begin{array}{lllll}2 & 3 & 4 & 2 & 2 \\
\end{array}$ & 2,6 \\
\hline horas consumidas na atividade de arrumação & $\begin{array}{lllll}4 & 3 & 5 & 2 & 3 \\
\end{array}$ & 3,4 \\
\hline horas consumidas na atividade de lavanderia & \begin{tabular}{lllll|}
2 & 2 & 4 & 3 & 3 \\
\end{tabular} & 2,8 \\
\hline horas consumidas na atividade de nutrição & $\begin{array}{lllll}4 & 3 & 5 & 4 & 4 \\
\end{array}$ & 4,0 \\
\hline horas consumidas na atividade de enfermagem & \begin{tabular}{lllll|}
5 & 5 & 5 & 4 & 5 \\
\end{tabular} & 4,8 \\
\hline horas consumidas na atividade médica & $\begin{array}{lllll}4 & 5 & 5 & 4 & 4\end{array}$ & 4,4 \\
\hline
\end{tabular}


As variáveis apontadas como menos relevantes para influenciar o desempenho das entidades referiam-se aos salários de médicos e outros profissionais, assim como a dimensão da área física e o número de horas consumidas na atividade de lavanderia. Destaca-se que, nesse último item, $40 \%$ das instituições consultadas também utilizavam serviços terceirizados de lavanderia, justificando as notas inferiores a 3. Os salários pagos aos profissionais de saúde e em geral foram considerados fatores com baixo impacto ao desempenho devido ao estabelecimento de faixas salariais de mercado que não proporcionavam variações significativas entre os próprios profissionais, mas foi destacado, pelos gestores das entidades sem fins lucrativos, que se deveria considerar como variável relevante a presença de colaboradores voluntários. A relação da área física por residente também não foi considerada relevante devido às grandes variações existentes entre as áreas totais e construídas das entidades, o que prejudicaria a comparação entre elas, além da variação de espaço utilizado pelos residentes com diferentes graus de dependência.

Após a discussão das características e relevância das principais variáveis presentes na literatura DEA para organizações da área de saúde, foi perguntado aos gestores quais seriam, sob a perspectiva administrativa, os insumos fundamentais para o desempenho, independentemente da lista anterior apresentada para avaliação, que pudessem representar as variáveis relacionadas ao capital e ao trabalho. Após a análise de conteúdo das respostas, as categorias mencionadas por mais de $80 \%$ dos entrevistados foram:

$\underline{\text { Insumos relacionados ao capital }}$

- Estrutura física / Bens e imóveis

- Valores totais gastos.

$\underline{\text { Insumos relacionados ao trabalho }}$

- Profissionais remunerados (incluindo terceirizados)

- Colaboradores voluntários.

Diante da categorização das respostas dos gestores às questões abertas e das notas de classificação dos itens relacionados aos insumos mais relevantes, foram selecionados para esta pesquisa, como inputs de capital e trabalho, as seguintes variáveis: 
- Valor contábil do Ativo Permanente, conforme as informações do Balanço Patrimonial do último exercício (2008);

- Valor contábil das despesas totais, conforme as informações da Demonstração do Superávit do exercício;

- Horas totais de trabalho, considerando-se as atividades remuneradas e voluntárias das instituições pesquisadas em base mensal.

Para atenuar os efeitos decorrentes do porte das organizações, todas as variáveis foram estimadas utilizando-se como denominador matemático o número total de residentes (leitos utilizados) das respectivas instituições.

Assim, as variáveis de inputs e outputs consideradas no cálculo da eficiência produtiva pela Análise Envoltória de Dados são apresentadas no Quadro 8, a seguir.

Quadro 8 - Quadro-resumo das variáveis relacionadas aos insumos e aos produtos

\begin{tabular}{|c|c|c|c|c|}
\hline $\mathrm{N}^{0}$ & Variáveis & Fórmulas / Descrição & Fontes & Relacionamento \\
\hline 1 & Output 1 & 1 - Taxa de mortalidade & \multirow{6}{*}{$\begin{array}{l}\text { Relatório interno da } \\
\text { entidade }\end{array}$} & \multirow{6}{*}{ Produtos } \\
\hline 2 & Output 2 & $\begin{array}{l}1 \text { - Taxa incidência de } \\
\text { doença diarreica aguda }\end{array}$ & & \\
\hline 3 & Output 3 & $\begin{array}{c}1 \text { - Taxa de incidência de } \\
\text { escabiose }\end{array}$ & & \\
\hline 4 & Output 4 & $\begin{array}{c}1 \text { - Taxa de incidência de } \\
\text { desidratação }\end{array}$ & & \\
\hline 5 & Output 5 & $\begin{array}{c}1 \text { - Taxa de prevalência de } \\
\text { úlcera de decúbito }\end{array}$ & & \\
\hline 6 & Output 6 & $\begin{array}{c}1 \text { - Taxa de prevalência de } \\
\text { desnutrição }\end{array}$ & & \\
\hline 7 & Input 1 & $\begin{array}{l}\text { Valor contábil do Ativo } \\
\text { Permanente } / \mathrm{n}^{\circ} \text { residentes }\end{array}$ & $\begin{array}{c}\text { Balanço } \\
\text { Patrimonial (último } \\
\text { exercício) }\end{array}$ & \multirow{3}{*}{ Insumos } \\
\hline 8 & Input 2 & $\begin{array}{l}\text { Valor contábil das } \\
\text { despesas totais / } \mathrm{n}^{\circ} \\
\text { residentes }\end{array}$ & $\begin{array}{c}\text { Balanço } \\
\text { Patrimonial (último } \\
\text { exercício) } \\
\end{array}$ & \\
\hline 9 & Input 3 & $\begin{array}{l}\text { Horas mensais médias de } \\
\text { todos os trabalhadores } \\
\text { remunerados e voluntários } \\
/ \mathrm{n}^{\circ} \text { residentes }\end{array}$ & $\begin{array}{l}\text { Relatório interno da } \\
\text { entidade }\end{array}$ & \\
\hline
\end{tabular}

O grau de eficiência calculado pelo modelo DEA variará de 0 (totalmente ineficiente) a 1 (totalmente eficiente) e será apresentado em valor percentual neste trabalho. Assim, as entidades situadas na fronteira de produção eficiente obterão o valor $100 \%$, enquanto aquelas que se distanciarem graficamente da fronteira obterão valores proporcionais e inferiores a $100 \%$. 


\subsection{Participação das receitas de origem estatal}

As transferências diretas de recursos financeiros de origem pública, tais como subvenções e doações, devem ser registradas, contabilmente, como receitas pelas entidades em análise e constar das respectivas demonstrações financeiras (CFC, 2005). O valor total das receitas obtidas por organizações sem fins lucrativos podem ser formadas, exclusivamente, por recursos oriundos de fontes estatais ou privadas, assim como podem contar com a participação de recursos de ambas as origens.

A participação dos recursos financeiros de origem estatal numa ILPI filantrópica é mensurada pela razão entre o valor das transferências públicas e o valor do total das receitas registradas na Demonstração do Superávit do Exercício, conforme apresentado na equação 9, e variará entre $0 \%$ (nenhuma transferência de fontes estatais) a 100\% (toda a receita obtida é de origem estatal).

$$
\text { PRES }=\frac{\text { VRES }}{V T R E} * 100
$$

Em que:

PRES = participação dos recursos financeiros de origem estatal;

VRES = valor total dos recursos públicos transferidos à ILPI em determinado exercício;

$\mathrm{VTRE}=$ valor total das receitas registradas em determinado exercício.

\subsection{Construção do indicador de disclosure}

O indicador de disclosure utilizado neste trabalho foi construído baseado nas principais categorias e itens informacionais identificados em estudos anteriores, mencionados na seção 2.4.3. Nesse sentido, optou-se pela seleção de itens que pudessem constatar e analisar a divulgação de informações obrigatórias e voluntárias, de natureza financeira e não-financeira. Optou-se por verificar a presença de itens de divulgação obrigatória porque eles podem apresentar características discriminatórias entre as organizações, uma vez que é possível 
ocorrer o descumprimento legal nesse sentido, conforme constatado em pesquisas anteriores (MILANI FILHO, 2008b).

Conforme a regulamentação do Conselho Federal de Contabilidade, o Quadro 9 contém os 10 itens obrigatórios selecionados, com as respectivas siglas.

\section{Quadro 9 - Itens obrigatórios selecionados}

\begin{tabular}{|rrlr|}
\hline $\mathrm{N}^{\mathrm{o}}$ & Sigla & \multicolumn{1}{c|}{ Itens obrigatórios } & NBC-T \\
\hline 1 & DISP & Disponibilização das demonstrações contábeis aos seus usuários & 6.1 .1 .1 \\
2 & PUBL & Publicação na imprensa oficial ou privada, em qualquer de suas modalidades & 6.1 .1 .2 \\
3 & REME & Remessa das demonstrações contábeis a todos os interessados & 6.1 .1 .2 \\
4 & COMU & Comunicação de que as demonstrações contábeis estão à disposição & 6.1 .1 .2 \\
5 & NOTA & Publicação de Notas Explicativas & 6.2 .2 .1 \\
6 & SEGR & Segregação de contas de receitas e despesas por atividades & 10.19 .2 .5 \\
7 & CRIT & Informações sobre os critérios de apuração das receitas e despesas & 10.19 .3 .3 \\
8 & ISEN & Demonstração das isenções previdenciárias (INSS) & 10.19 .3 .3 \\
9 & SUBV & Montante das subvenções recebidas & 10.19 .3 .3 \\
10 & OBLP & Descrição das condições (taxas, prazos etc) das obrigações de L.Prazo & 10.19 .3 .3 \\
\hline
\end{tabular}

Os itens informacionais sobre disclosure voluntário basearam-se nos trabalhos de Botosan (1997), Hail (2002), Eng e Mak (2003), Lanzana (2004) e Bhojraj et al. (2004). Conforme observado no Quadro 10 foram selecionados, por conveniência, 19 itens que apresentaram relação direta com o contexto das OTS e foram desconsiderados os itens pertinentes, exclusivamente, às empresas de mercado (como, por exemplo, criação de valor ao acionista). 


\section{Quadro 10 - Itens voluntários selecionados}

\begin{tabular}{|rrlc|}
\hline $\mathrm{N}^{\circ}$ & Sigla & \multicolumn{1}{c}{ Itens voluntários } & Referência \\
\hline 1 & HIST & História da entidade & Enc e Mak, Bhojraj \\
2 & SERV & Descrição dos serviços prestados & Botosan, Enc e Mak \\
3 & META & Metas e objetivos & Botosan, Enc e Mak \\
4 & FCSU & Fatores críticos de sucesso & Hail \\
5 & EVEN & Eventos importantes no ano & Enc e Mak \\
6 & ESTR & Estrutura organizacional & Hail, Enc e Mak \\
7 & RELA & Relatório de atividades & Lanzana, Bhojraj \\
8 & INRH & Investimentos em recursos humanos & Hail \\
9 & SUMA & Sumário dos resultados históricos & Enc e Mak \\
10 & CCAP & Custos da atividade de captação de recursos & Bhojraj \\
11 & RECB & Evidenciação dos recursos com finalidade exclusiva & Bhojraj \\
12 & FUNC & Número de funcionários remunerados & Enc e Mak \\
13 & VOLU Número de voluntários e horas dedicadas por período & Bhojraj \\
14 & SATU & Satisfação dos usuários dos serviços & Hail \\
15 & SATF & Satisfação dos funcionários & Hail \\
16 & PINV & Políticas e Projetos e investimentos & Enc e Mak \\
17 & PROJ & Resultados e desempenhos projetados & Enc e Mak, Bhojraj \\
18 & WEBS & Informações gerais disponíveis em website & Bhojraj \\
19 & MISS & Declaração da missão da organização & Bhojraj \\
\hline
\end{tabular}

Assim como realizados pelos autores citados, a pontuação de cada item variou segundo uma escala determinada por conveniência. Para este trabalho, adotou-se a mesma escala de Bhojraj et al. (2004), em que 0 (zero) representa a ausência e 1 (um) a presença da informação. Nenhum item apresenta peso diferenciado para o cálculo da pontuação final da entidade em análise. Assim, o indicador de disclosure da organização (ID) é calculado pela soma total de pontos entre os 10 itens obrigatórios (IO) e os 19 de divulgação voluntária (IV), podendo variar da nota mínima (zero) até a máxima (29).

$$
I D=I O+I V
$$

O nível de disclosure da organização (DISC) é calculado pela razão entre a pontuação obtida pelo indicador de disclosure da organização (ID) e total de pontos possíveis (nesse caso, 29 pontos). Assim, o resultado dessa equação variará de $0 \%$ (ausência de todos os itens analisados) a $100 \%$ (presença de todos os itens analisados).

$$
D I S C=\frac{I D}{29} * 100
$$




\subsection{Coleta de dados}

Inicialmente, as entidades selecionadas foram contatadas via telefone, a fim de se obter o nome do responsável técnico e para a confirmação dos dados cadastrais, além de serem informadas sobre os propósitos desta investigação científica. Posteriormente, enviou-se, ao responsável técnico ou à pessoa indicada no primeiro contato, uma carta formal de apresentação da pesquisa, destacando-se as principais características e o compromisso de confidencialidade deste estudo. Juntamente à carta de apresentação, foi enviado o questionário (Apêndice 2) para a identificação das principais características da organização e para a coleta dos seguintes dados referentes ao exercício de 2008:

Eficiência produtiva - dados dos produtos

1. Taxa de mortalidade em idosos residentes

2. Taxa de incidência de doença diarreica aguda

3. Taxa de incidência de escabiose

4. Taxa de incidência de desidratação

5. Taxa de prevalência de úlcera de decúbito

6. Taxa de prevalência de desnutrição.

Eficiência produtiva - dados dos insumos (capital e trabalho)

1. Valor do Ativo Permanente

2. Despesas totais

3. Quantidade de funcionários remunerados

4. Quantidade de voluntários

5. Quantidade de horas mensais médias disponibilizadas pelos voluntários.

\section{Composição das receitas operacionais}

1. Montante das receitas de origem estatal (transferências públicas diretas, como subvenções e convênios)

2. Montante da receita de origem privada (exceto por faturamento de vendas de bens e prestação de serviços)

3. Montante da receita originada das vendas de bens e prestação de serviços. 
$\underline{\text { Itens relacionados ao Disclosure }}$

1. Frequência de publicação das demonstrações financeiras

2. Remessa das demonstrações contábeis aos interessados

3. Acessibilidade pública das demonstrações financeiras

4. Publicação das Notas Explicativas

5. Divulgação de relatório de atividades

6. Divulgação da missão da organização

7. Informações sobre a história da entidade

8. Descrição dos serviços prestados

9. Informações sobre metas e objetivos estabelecidos

10. Informações sobre os fatores críticos de sucesso

11. Relação de eventos importantes no ano

12. Informações sobre a estrutura organizacional

13. Informações sobre investimentos em recursos humanos

14. Sumário dos resultados históricos

15. Custos da atividade de captação de recursos

16. Evidenciação dos recursos com finalidade exclusiva

17. Número de funcionários remunerados

18. Número de voluntários e horas dedicadas por período

19. Informações sobre a satisfação dos usuários dos serviços

20. Informações sobre a satisfação dos funcionários

21. Informações sobre políticas e projetos de investimentos

22. Resultados e desempenhos projetados

23. Informações gerais disponíveis em website

24. Declaração da missão da organização.

O conteúdo informacional das perguntas sobre disclosure relacionadas no questionário abrangem, predominantemente, os itens de divulgação voluntária. Os itens relacionados à divulgação obrigatória foram analisados, quando disponíveis, em fontes primárias ou secundárias. 


\subsection{Análise de regressão linear}

O modelo de análise de regressão linear, apresentado a seguir, foi utilizado para verificar a possível relação entre as variáveis em estudo com o nível de eficiência produtiva das ILPIs.

$$
E P=\beta_{0}+\beta_{1} V A R+u
$$

Em que:

$\mathrm{EP}=$ grau de eficiência produtiva calculado pelo modelo DEA, expresso em valor percentual; $\mathrm{VAR}=$ variável em estudo; $\mathrm{u}=$ termo de erro.

Os pressupostos da análise de regressão são:

- $\quad$ Normalidade dos resíduos;

- Homoscedasticidade dos resíduos;

- Linearidade dos coeficientes;

- Ausência de autocorrelação serial nos resíduos;

- Multicolinearidade entre as variáveis independentes.

Os cálculos e testes necessários do modelo de regressão foram realizados com a utilização do programa Statistical Package for the Social Sciences - SPSS. No Capítulo 4, referente à análise de dados, são apresentados os respectivos resultados.

Após a interpretação dos resultados obtidos, foram testadas as hipóteses formuladas inicialmente, assim como as questões de pesquisa que orientaram este trabalho foram respondidas. 


\section{ANÁLISE DOS DADOS}

Neste capítulo são apresentados e analisados os dados sobre as variáveis das ILPIs selecionadas, permitindo-se, inicialmente, o delineamento do perfil das organizações. Posteriormente, analisa-se o grau de eficiência das ILPIs, utilizando-se o modelo nãoparamétrico DEA orientado a input. São testadas, ainda, as hipóteses estabelecidas no início deste trabalho, servindo-se da análise de regressão linear para verificar a existência, ou não, de possíveis relações significativas entre a eficiência produtiva e as variáveis independentes: disclosure, transferências públicas, receitas próprias e outras transferências privadas e, também, resultado financeiro (receitas - despesas).

\subsection{Perfil das ILPIs}

\subsubsection{Tipos de residentes}

A seguir, são apresentados os dados sobre as características dos residentes das ILPIs pesquisadas, relacionados ao grau de dependência e à quantidade média dos idosos internados.

Tabela 12 - Quantidade média de residentes por ILPI

Statistics

\begin{tabular}{|c|c|c|}
\hline \multicolumn{3}{|l|}{ Qtde res } \\
\hline \multirow[t]{2}{*}{$\bar{N}$} & Valid & 42 \\
\hline & Missing & 0 \\
\hline \multicolumn{2}{|l|}{ Mean } & 45,8333 \\
\hline \multicolumn{2}{|c|}{ Std. Error of Mean } & 3,44627 \\
\hline \multicolumn{2}{|l|}{ Median } & 41,5000 \\
\hline \multicolumn{2}{|l|}{ Mode } & $26,00^{a}$ \\
\hline \multicolumn{2}{|c|}{ Std. Deviation } & 22,33440 \\
\hline \multicolumn{2}{|l|}{ Variance } & 498,82520 \\
\hline \multicolumn{2}{|l|}{ Range } & 98,00 \\
\hline \multicolumn{2}{|l|}{ Minimum } & 12,00 \\
\hline \multicolumn{2}{|l|}{ Maximum } & 110,00 \\
\hline \multicolumn{2}{|l|}{ Sum } & 1925,00 \\
\hline \multirow[t]{3}{*}{ Percentiles } & 25 & 30,5000 \\
\hline & 50 & 41,5000 \\
\hline & 75 & 59,5000 \\
\hline
\end{tabular}

a. Multiple modes exist. The smallest value is shown 
Tabela 13 - Participação por tipo de residente

Statistics

\begin{tabular}{|ll|r|r|r|}
\hline & & Part \% G1 & Part \% G2 & Part \% G3 \\
\hline $\mathrm{N}$ & Valid & 42 & 42 & 42 \\
& Missing & 0 & 0 & 0 \\
Mean & & 48,3214 & 33,2167 & 18,4571 \\
Std. Error of Mean & 2,38796 & 1,67431 & 1,66122 \\
Median & 48,7500 & 33,3000 & 17,6500 \\
Mode & $35,00^{\mathrm{a}}$ & $25,00^{\mathrm{a}}$ &, $00^{\mathrm{a}}$ \\
Std. Deviation & & 15,47578 & 10,85078 & 10,76592 \\
Variance & 239,49977 & 117,73947 & 115,90495 \\
Range & & 78,10 & 67,10 & 49,00 \\
Minimum & 16,30 & 5,60 &, 00 \\
Maximum & & 94,40 & 72,70 & 49,00 \\
Sum & & 2029,50 & 1395,10 & 775,20 \\
Percentiles & 25 & 37,7750 & 25,9750 & 11,0000 \\
& 50 & 48,7500 & 33,3000 & 17,6500 \\
& 75 & 58,3750 & 38,8250 & 25,0000 \\
\hline
\end{tabular}

a. Multiple modes exist. The smallest value is shown

Tabela 14 - Distribuição por tipo de residente

Statistics

\begin{tabular}{|ll|r|r|r|}
\hline & & res G1 & res G2 & \multicolumn{1}{c|}{ res G3 } \\
\hline $\mathrm{N}$ & Valid & 42 & 42 & 42 \\
Mean & Missing & 0 & 0 & 0 \\
Std. Error of Mean & & 21,3095 & 15,4524 & 9,0714 \\
Median & 1,67286 & 1,42412 & 1,09872 \\
Mode & 19,0000 & 12,5000 & 8,0000 \\
Std. Deviation & $17,00^{\mathrm{a}}$ & 10,00 & $1,00^{\mathrm{a}}$ \\
Variance & 10,84140 & 9,22933 & 7,12054 \\
Range & 117,53600 & 85,18060 & 50,70209 \\
Minimum & 48,00 & 41,00 & 25,00 \\
Maximum & 5,00 & 1,00 &, 00 \\
Sum & & 53,00 & 42,00 & 25,00 \\
Percentiles & 25 & 895,00 & 649,00 & 381,00 \\
& & 13,0000 & 10,0000 & 3,0000 \\
& 50 & 19,0000 & 12,5000 & 8,0000 \\
& 75 & 28,0000 & 19,2500 & 13,2500 \\
\hline
\end{tabular}

a. Multiple modes exist. The smallest value is shown

A média de residentes por instituição foi de 45,8 pessoas, constatando-se a predominância de pessoas Grau I (independentes), representando 48,3\% do total. Os residentes Graus II e III representaram, respectivamente, $33,2 \%$ e 18,5\%. Com relação à posição relativa das 
observações na distribuição, o $1^{\mathrm{o}}$ quartil, relativo à participação por tipo de residente, foi de $37,8 \%$, o $2^{\circ}$ quartil (mediana) foi igual a $48,8 \%$ e o $3^{\circ}$ quartil foi de $58,4 \%$.

O número médio de residentes Grau I foi de 21,3 pessoas por entidade, com presença mínima de 5,0 e máxima de 53,0 pessoas. O desvio-padrão calculado para a amostra foi de 10,8 pessoas independentes. $\mathrm{O} 1^{\circ}$ quartil foi de 13,0 pessoas, a mediana foi igual a 19,0 pessoas e o $3^{\circ}$ quartil foi de 28,0 residentes.

O número médio de residentes Grau II foi de 15,4 pessoas por entidade, com presença mínima de 1,0 e máxima de 42,0 pessoas. O desvio-padrão calculado para a amostra foi de 9,2 pessoas semi-independentes. O primeiro quartil foi de 10,0 pessoas, a mediana foi igual a 12,5 pessoas e o $3^{\circ}$ quartil foi de 19,3 residentes.

O número médio de residentes Grau III foi de 9,1 pessoas por entidade, com presença mínima de 0 (zero) e máxima de 25,0 pessoas. O desvio-padrão calculado para a amostra foi de 7,1 pessoas dependentes. O primeiro quartil foi de 3,0 pessoas, a mediana foi igual a 8,0 pessoas e o $3^{\circ}$ quartil foi de 13,3 residentes.

\subsubsection{Trabalhadores remunerados e voluntários}

Conforme observado na Tabela 15, a quantidade média de funcionários remunerados foi de 33,7 pessoas por ILPI, representando $62,3 \%$ do total de trabalhadores e 20,4 voluntários, representando uma participação de 37,7\%. Assim, a quantidade média de trabalhadores (assalariados e voluntários) foi de 54,1 pessoas por instituição.

O número de trabalhadores remunerados variou de 7,0 a 203,0 pessoas, expressando a diversidade de porte das organizações analisadas. O desvio-padrão desse grupo foi de 32,3 pessoas. $\mathrm{O}$ valor do $1^{\circ}$ quartil de assalariados foi de 15 pessoas, o $2^{\circ}$ quartil foi de 25,5 pessoas e o $3^{\circ}$ quartil foi igual a 40,5 pessoas. 
Tabela 15 - Quantidade média de trabalhadores por ILPI

Statistics

\begin{tabular}{|lr|r|r|}
\hline & & Qde trab rem & $\begin{array}{c}\text { Qde } \\
\text { voluntarios }\end{array}$ \\
\hline N & Valid & 42 & 42 \\
& Missing & 0 & 0 \\
Mean & & 33,7143 & 20,3571 \\
Std. Error of Mean & & 4,99108 & 3,93941 \\
Median & 25,5000 & 10,0000 \\
Mode & $9,00^{\mathrm{a}}$ & 10,00 \\
Std. Deviation & & 32,34591 & 25,53030 \\
Variance & 1046,25784 & 651,79617 \\
Range & 196,00 & 114,00 \\
Minimum & & 7,00 &, 00 \\
Maximum & & 203,00 & 114,00 \\
Sum & & 1416,00 & 855,00 \\
Percentiles & 25 & 15,0000 & 6,0000 \\
& 50 & 25,5000 & 10,0000 \\
& 75 & 40,5000 & 20,7500 \\
\hline
\end{tabular}

a. Multiple modes exist. The smallest value is shown

Há instituições que não utilizaram mão-de-obra voluntária no período analisado. O número máximo de voluntários presentes na amostra, numa única entidade, foi de 114,0 pessoas. $\mathrm{O}$ desvio-padrão calculado para o grupo de voluntários foi de 25,5 pessoas. O primeiro quartil foi de 6,0 voluntários, o $2^{\circ}$ quartil foi igual a 10,0 pessoas e o $3^{\circ}$ quartil foi de 20,8 pessoas.

Conforme observado na Tabela 16, a média de horas trabalhadas por residente, considerandose a mão-de-obra assalariada e voluntária juntas foi de 130,6 horas mensais por ILPI. O desvio-padrão foi de 74,7 horas mensais. Observa-se o valor mínimo de 45,0 horas mensais trabalhadas por residente (considerando-se remunerados e voluntários) ante o máximo de 443,4 horas mensais por residente. O tempo do $1^{\circ}$ quartil foi de 83,3 horas, a mediana foi igual a 105,4 horas e o $3^{\circ}$ quartil foi de 164,6 horas, todos os valores calculados por residente. 
Tabela 16 - Horas remuneradas e voluntárias por residente Statistics

\begin{tabular}{|ll|r|r|r|}
\hline & \multicolumn{1}{|c|}{$\begin{array}{c}\text { horas tot } \\
\text { trab+vol/res }\end{array}$} & Hr rem por r & Hr vol por r \\
\hline $\mathrm{N}$ & Valid & 42 & 42 & 42 \\
Mean & Missing & 0 & 0 & 0 \\
Std. Error of Mean & & 130,6072 & 125,4525 & 5,1547 \\
Median & 11,51893 & 11,17614 &, 83610 \\
Mode & 105,3541 & 97,8679 & 3,1250 \\
Std. Deviation & & 208,00 & 88,00 &, 00 \\
Variance & 74,65119 & 72,42965 & 5,41857 \\
Range & 5572,79972 & 5246,05404 & 29,36092 \\
Minimum & 398,35 & 385,43 & 21,71 \\
Maximum & 45,02 & 45,02 &, 00 \\
Sum & & 443,37 & 430,46 & 21,71 \\
Percentiles & 25 & 5485,50 & 5269,01 & 216,50 \\
& 50 & 83,2783 & 79,8000 & 1,2991 \\
& 75 & 105,3541 & 97,8679 & 3,1250 \\
& & 164,5848 & 160,3964 & 7,7049 \\
\hline
\end{tabular}

Considerando-se somente a mão-de-obra assalariada, o tempo médio mensal trabalhado por residente foi de 125,4 horas por ILPI e o desvio-padrão foi de 72,4 horas mensais. Observa-se o valor mínimo de 45,0 horas mensais remuneradas dedicadas por residente ante o máximo de 430,5 horas mensais por residente. O tempo médio remunerado do $1^{\circ}$ quartil foi de 79,8 horas, a mediana foi igual a 97,9 horas e o $3^{\circ}$ quartil foi de 160,4 horas, todos os valores calculados por residente em bases mensais.

Os trabalhadores voluntários dedicam, em média, 5,2 horas mensais em suas atividades, com significativo desvio-padrão de 5,4 horas. Há ILPIs que não contam com o trabalhador voluntário, o que faz com que o valor mínimo da faixa de horas mensais dedicadas por esse grupo seja igual a zero. O valor máximo de horas mensais observado foi de 21,7 horas. 


\subsubsection{Ativo Permanente}

Tabela 17 - Ativo Permanente

\begin{tabular}{|c|c|c|c|}
\hline \multicolumn{4}{|c|}{ Statistics } \\
\hline & & $\begin{array}{c}\text { Ativo } \\
\text { Permanente }\end{array}$ & AP/res \\
\hline \multirow[t]{2}{*}{$\bar{N}$} & Valid & 42 & 42 \\
\hline & Missing & 0 & 0 \\
\hline \multicolumn{2}{|l|}{ Mean } & 1331371,032 & 22435,94 \\
\hline \multicolumn{2}{|c|}{ Std. Error of Mean } & 421848,5538 & 5867,120 \\
\hline \multicolumn{2}{|l|}{ Median } & 291695,6256 & 5440,9894 \\
\hline \multicolumn{2}{|l|}{ Mode } & $23043,02^{a}$ & $765,97^{a}$ \\
\hline \multicolumn{2}{|c|}{ Std. Deviation } & 2733891,091 & 38023,28 \\
\hline \multicolumn{2}{|l|}{ Variance } & $7,474 \mathrm{E}+12$ & $1,4 \mathrm{E}+09$ \\
\hline \multicolumn{2}{|l|}{ Range } & 14404956,98 & 173065,36 \\
\hline \multicolumn{2}{|l|}{ Minimum } & 23043,02 & 765,97 \\
\hline \multicolumn{2}{|l|}{ Maximum } & 14428000,00 & 173831,33 \\
\hline \multicolumn{2}{|l|}{ Sum } & 55917583,33 & 942309,68 \\
\hline \multirow[t]{3}{*}{ Percentiles } & 25 & 95013,8982 & 2699,9983 \\
\hline & 50 & 291695,6256 & 5440,9894 \\
\hline & 75 & 1099068,032 & 24412,84 \\
\hline
\end{tabular}

a. Multiple modes exist. The smallest value is shown

O valor médio do Ativo Permanente das ILPIs da amostra, levando-se em consideração o exercício de 2008, foi de $\mathrm{R} \$ 1.331,4$ mil. Destacou-se a diferença de porte das organizações, cujo valor mínimo desse grupo contábil foi de $\mathrm{R} \$ 23,0$ mil e o valor máximo de $\mathrm{R} \$ 14.428,0$ mil, apresentando um desvio-padrão de $\mathrm{R} \$ 2.733,9$ mil. O primeiro quartil foi igual a $\mathrm{R} \$ 95,0$ mil, o $2^{\circ}$ quartil foi igual a $\mathrm{R} \$ 291,7$ mil e o $3^{\circ}$ quartil foi de $\mathrm{R} \$ 1.099,1 \mathrm{mil}$.

Considerando-se os valores por residente, a média do Ativo Permanente por instituição equivaleu a R\$22,4 mil. Observa-se que o valor mínimo foi de $\mathrm{R} \$ 0,8$ mil, ante o valor máximo de $\mathrm{R} \$ 173,8$ mil. O desvio-padrão foi igual a $\mathrm{R} \$ 38,0$ mil por residente. O primeiro quartil foi igual a $\mathrm{R} \$ 2,7$ mil, o $2^{\circ}$ quartil foi igual a $\mathrm{R} \$ 5,4$ mil e o $3^{\circ}$ quartil foi de $\mathrm{R} \$ 24,4$ mil. 


\subsubsection{Despesas totais}

Tabela 18 - Despesas totais

Statistics

\begin{tabular}{|ll|r|r|}
\hline & & Desp Totais & \multicolumn{1}{c|}{ DT/res } \\
\hline N & Valid & 42 & 42 \\
Mean & & 0 & 0 \\
Std. Error of Mean & & 590926,446 & 12884,52 \\
Median & 98756,5135 & 1651,982 \\
Mode & & 456066,251 & 9558,2887 \\
Std. Deviation & & $25546,05^{\mathrm{a}}$ & $655,03^{\mathrm{a}}$ \\
Variance & 640015,356 & 10706,06 \\
Range & & $4,096 \mathrm{E}+11$ & $1,1 \mathrm{E}+08$ \\
Minimum & 3834019,06 & 52253,89 \\
Maximum & 25546,05 & 655,03 \\
Sum & & 3859565,11 & 52908,92 \\
Percentiles & 25 & 24818910,7 & 541149,87 \\
& 50 & 206683,208 & 7028,3349 \\
& 75 & 456066,251 & 9558,2887 \\
& & 740336,046 & 14814,01 \\
\hline
\end{tabular}

a. Multiple modes exist. The smallest value is shown

O valor médio das despesas totais das ILPIs, com referência ao exercício anual, foi de R\$ 590,9 mil, observando-se o valor mínimo de $\mathrm{R} \$ 25,5$ mil e o valor máximo de $\mathrm{R} \$ 3.859,6$ mil. O desvio-padrão foi de R $\$ 640,0$ mil, explicitando a significativa diferença de porte entre as organizações. O primeiro quartil foi igual a $\mathrm{R} \$ 206,7$ mil, o valor da mediana foi de $\mathrm{R} \$ 456,1$ mil e o $3^{\circ}$ quartil foi de $\mathrm{R} \$ 740,3$ mil.

A média dos valores relativos às despesas totais, considerando-se o número de residentes, foi igual a R \$12,9 mil. O menor valor de despesas totais por residente foi de R 0,7 mil, ante o maior valor de $\mathrm{R} \$ 52,9$ mil. O desvio-padrão foi igual a $\mathrm{R} \$ 10,7$ mil por residente. O primeiro quartil foi igual a $\mathrm{R} \$ 7,0$ mil, o valor da mediana foi de $\mathrm{R} \$ 9,6$ mil e o $3^{\circ}$ quartil foi de $\mathrm{R} \$$ 14,8 mil. 


\subsubsection{Indicadores de desempenho - Anvisa}

Tabela 19 - Indicadores de desempenho da Anvisa

Statistics

\begin{tabular}{|ll|r|r|r|r|r|r|}
\hline & & 1-tx mort & 1-tx diarr & 1-tx escab & 1-tx desidr & 1-tx ulc dec & 1-tx desnutr \\
\hline $\mathrm{N}$ & Valid & 42 & 42 & 42 & 42 & 42 & 42 \\
& Missing & 0 & 0 & 0 & 0 & 0 & 0 \\
Mean & & 98,8929 & 98,4238 & 99,3905 & 98,6595 & 98,5976 & 98,5500 \\
Std. Error of Mean & & 10671 &, 20905 &, 13299 &, 19589 &, 19777 &, 20845 \\
Median & 99,0000 & 99,0000 & 99,8000 & 99,0000 & 99,0000 & 98,8000 \\
Mode & 99,00 & 99,00 & 100,00 & 100,00 & 100,00 & 100,00 \\
Std. Deviation &, 69155 & 1,35481 &, 86188 & 1,26954 & 1,28167 & 1,35093 \\
Variance &, 47824 & 1,83552 &, 74283 & 1,61174 & 1,64268 & 1,82500 \\
Range & 2,60 & 5,90 & 3,40 & 4,50 & 4,80 & 5,50 \\
Minimum & 97,40 & 94,10 & 96,60 & 95,50 & 95,20 & 94,50 \\
Maximum & & 100,00 & 100,00 & 100,00 & 100,00 & 100,00 & 100,00 \\
Sum & 4153,50 & 4133,80 & 4174,40 & 4143,70 & 4141,10 & 4139,10 \\
Percentiles & 25 & 98,5000 & 97,7750 & 99,2000 & 97,7750 & 97,8250 & 97,9000 \\
& 50 & 99,0000 & 99,0000 & 99,8000 & 99,0000 & 99,0000 & 98,8000 \\
& 75 & 99,4000 & 99,4250 & 100,0000 & 100,0000 & 99,9000 & 99,8500 \\
\hline
\end{tabular}

Todos os valores apresentados na Tabela 19 expressaram a diferença entre os indicadores de desempenho estabelecidos pela Anvisa e o valor de $100 \%$. Assim, quanto maior foi o valor encontrado na tabela, menor a taxa em análise (100\% - valor do indicador).

\subsubsection{Mortalidade}

O indicador médio relativo à sobrevivência foi de $98,9 \%$, significando que a taxa média de ocorrência de óbitos, por instituição, foi de $1,1 \%$, ou seja, em média, num período de 12 meses, a cada 100,0 residentes, 1,1 falecem. O desvio-padrão calculado para a amostra foi de 0,7\% residentes e observou-se o valor mínimo de 97,4\%, equivalentes a uma taxa de mortalidade máxima de 2,6\%. Em algumas ILPIs não foram registrados casos de óbito no período analisado, por isso observou-se o valor máximo de $100 \%$ de sobrevivência, equivalentes a $0 \%$ de falecimentos no período. O primeiro quartil foi igual a $98,5 \%$, o valor do $2^{\circ}$ quartil foi de $99,0 \%$ e o $3^{\circ}$ quartil foi de $99,4 \%$.

\subsubsection{Doença diarreica}

O indicador médio relativo à ausência de doença diarreica foi de 98,4\%, significando que a taxa média de ocorrência desse tipo de doença, por instituição, foi de 1,6\%. O desvio-padrão 
calculado para a amostra foi de 1,4\%. Observou-se o valor mínimo de 94,1\%, equivalentes a uma taxa de ocorrência de doença diarreica máxima de 5,9\%. Em algumas ILPIs não foram registrados casos desse tipo de doença no período analisado, por isso observou-se o valor máximo de $100 \%$ de ausência de casos, equivalentes a $0 \%$ de doentes no período. O primeiro quartil foi igual a $97,8 \%$, o valor do $2^{\circ}$ quartil foi de $99,0 \%$ e o $3^{\circ}$ quartil foi de $99,4 \%$.

\subsubsection{Escabiose}

O indicador médio relativo à ausência de casos de escabiose foi de 99,4\%, significando que a taxa média de ocorrência desse tipo de doença, por instituição, foi de $0,6 \%$. O desvio-padrão calculado para a amostra foi de $0,9 \%$. Observou-se o valor mínimo de $96,6 \%$, equivalentes a uma taxa de ocorrência de casos de escabiose que atingiu, no máximo, o valor de 3,4\%. Em algumas ILPIs não foram registrados casos desse tipo de ocorrência no período analisado, por isso observou-se o valor máximo de $100 \%$ de ausência de casos, equivalentes a $0 \%$ de registros no período. O primeiro quartil foi igual a $99,2 \%$, o valor do $2^{\circ}$ quartil foi de $99,8 \%$ e o $3^{\circ}$ quartil foi de $100,0 \%$.

\subsubsection{Desidratação}

O indicador médio relativo à ausência de casos de desidratação foi de 98,7\%, significando que a taxa média de ocorrência desse tipo de caso, por instituição, foi de 1,3\%. O desvio-padrão calculado para a amostra foi de 1,3\%. Observou-se o valor mínimo de 95,5\%, equivalentes a uma taxa de ocorrência de casos de desidratação máxima de 4,5\%. Em algumas ILPIs não foram registrados casos dessa natureza no período analisado, por isso observou-se o valor máximo de $100 \%$ de ausência de casos, equivalentes a $0 \%$ de ocorrências no período. $\mathrm{O}$ primeiro quartil foi igual a $97,8 \%$, o valor do $2^{\circ}$ quartil foi de $99,0 \%$ e o $3^{\circ}$ quartil foi de $100,0 \%$.

\subsubsection{5 Úlcera de decúbito}

O indicador médio relativo à ausência de casos de úlcera de decúbito foi de 98,6\%, significando que a taxa média de ocorrência desse tipo de doença, por instituição, foi de 1,4\%. O desvio-padrão calculado para a amostra foi de 1,3\%. Observou-se o valor mínimo de $95,2 \%$, equivalentes a uma taxa de ocorrência de casos de úlcera de decúbito que atingiu, no 
máximo, o valor de 4,8\%. Em algumas ILPIs não foram registrados casos desse tipo no período analisado, por isso observou-se o valor máximo de $100 \%$ de ausência de casos, equivalentes a $0 \%$ de registros no período. O primeiro quartil foi igual a $97,8 \%$, o valor do $2^{\circ}$ quartil foi de $99,0 \%$ e o do $3^{\circ}$ quartil foi de $99,9 \%$.

\subsubsection{Desnutrição}

O indicador médio relativo à ausência de casos de desnutrição foi de 98,6\%, significando que a taxa média de ocorrência desse tipo de caso, por instituição, foi de 1,4\%. O desvio-padrão calculado para a amostra foi de 1,4\%. Observou-se o valor mínimo de 94,5\%, equivalentes a uma taxa de casos de desnutrição que atingiu, no máximo, o valor de 5,5\%. Em algumas ILPIs não foram registrados casos desse tipo no período analisado, por isso observou-se o valor máximo de $100 \%$ de ausência de casos, equivalentes a $0 \%$ de registros no período. $\mathrm{O}$ primeiro quartil foi igual a $97,9 \%$, o valor do $2^{\circ}$ quartil foi de $98,8 \%$ e o do $3^{\circ}$ quartil foi de $99,9 \%$.

\subsubsection{Correlações entre dependência e trabalhadores}

Tabela 20 - Correlações entre dependência e trabalhadores

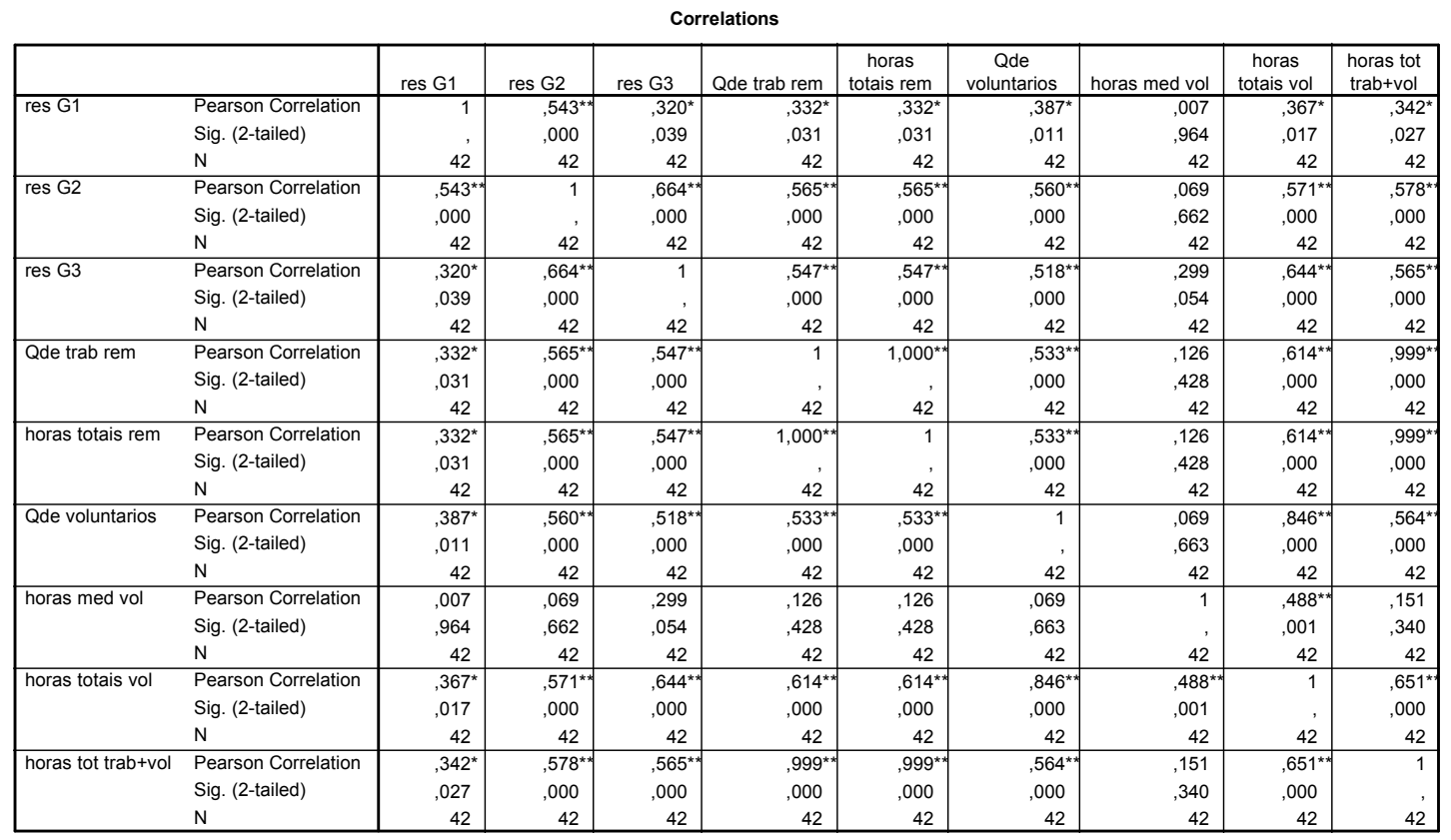

**. Correlation is significant at the 0.01 level (2-tailed).

${ }^{*}$. Correlation is significant at the 0.05 level (2-tailed). 
Conforme os valores correlacionais observados na Tabela 20, há relações significativas envolvendo a composição dos residentes, segundo o grau de dependência. A quantidade de residentes Grau I está positivamente relacionada com os residentes Grau II $(0,543)$ e Grau III $(0,320)$, indicando que a proporção de residentes guarda relação entre os respectivos graus.

As quantidades de funcionários remunerados e colaboradores voluntários também apresentam correlação positiva, entre si $(0,533)$, e com a proporção de residentes (fato esse que se mostra esperado diante da necessidade de atendimento proporcional à quantidade de usuários dos serviços), com maior ênfase na relação com semidependentes e dependentes. Apesar de a quantidade de horas dedicadas pelos assalariados apresentar relação significativa e positiva com a quantidade de residentes conforme o grau de dependência, a quantidade de horas mensais dedicadas pelos voluntários às ILPIs não guarda relação significativa com a quantidade de residentes Grau I $(0,007)$, Grau II $(0,069)$ e Grau III $(0,299)$, indicando que as horas disponibilizadas da mão-de-obra voluntária para a amostra considerada não se vincula, significativamente, com a distribuição dos residentes.

\subsubsection{Composição das receitas}

Tabela 21 - Composição da receita nominal

Statistics

\begin{tabular}{|ll|r|r|r|}
\hline & & $\begin{array}{c}\text { Transf } \\
\text { Publica }\end{array}$ & $\begin{array}{c}\text { Transf } \\
\text { Pub+Priv }\end{array}$ & Receita Total \\
\hline N & Valid & 42 & 42 & 42 \\
Mean & & 0 & 0 & 0 \\
Std. Error of Mean & 99995,49 & 469813,4 & 569808,9048 \\
Median & 17574,31 & 76256,12 & 78314,31206 \\
Mode & 66387,07 & 376740,7 & 436413,3294 \\
Std. Deviation & &, $00^{a}$ & $37046,09^{a}$ & 91857,13 \\
Variance & 113894,6 & 494196,2 & 507534,7495 \\
Range & $1,3 \mathrm{E}+10$ & $2,44 \mathrm{E}+11$ & $2,576 \mathrm{E}+11$ \\
Minimum & 664228,00 & 2918533 & 2933722,30 \\
Maximum &, 00 & 37046,09 & 91857,13 \\
Sum & & 664228,00 & 2955579 & 3025579,43 \\
Percentiles & 25 & 4199811 & 19732163 & 23931974,00 \\
& 50 & 48314,58 & 166024,2 & 236264,9778 \\
& 75 & 66387,07 & 376740,7 & 436413,3294 \\
\hline
\end{tabular}

a. Multiple modes exist. The smallest value is shown 
O valor médio nominal das transferências públicas às ILPIs componentes da amostra no exercício fiscal de 2008 foi de, aproximadamente, R\$ 100,0 mil, com desvio-padrão de R\$ 113,9 mil. O maior valor nominal observado foi de $\mathrm{R} \$ 664,2$ mil, contrastando com organizações que não receberam transferências públicas. $\mathrm{O}$ valor do primeiro quartil foi de $\mathrm{R} \$$ 48,3 mil. Os valores do $2^{\circ}$ e $3^{\circ}$ quartis foram de $\mathrm{R} \$ 66,4$ mil e 112,3 mil, respectivamente.

Os dados coletados sobre a geração própria de renda e o valor transferido por pessoas físicas e jurídicas privadas apresentaram uma certa inconsistência, pois detectou-se que algumas instituições não apresentavam receitas próprias, mas apresentavam um valor significativo nos dados referentes às outras transferências privadas. Em contato confirmatório com essas instituições após a coleta de dados, verificou-se que algumas organizações somaram os valores recebidos pela cobrança de serviços operacionais (mensalidades, venda de produtos, entre outros) com os valores recebidos de doações e outras transferências da iniciativa privada. Devido a essa situação, para efeito desta pesquisa, a análise de dados considerou os valores somados de Receitas Próprias e Transferências Privadas, desconsiderando-se os valores individuais de cada um desses grupos. Nesse sentido, constatou-se que o valor médio nominal decorrente da venda de produtos e recebimento de outras transferências privadas foi de $\mathrm{R} \$ 469,8$ mil. O desvio-padrão desse grupo foi de $\mathrm{R} \$ 494,2$ mil, relacionado à diferença de porte entre as organizações. O maior valor nominal recebido foi de $\mathrm{R} \$ 2.955,6$ mil e o valor mais baixo observado foi de $\mathrm{R} \$ 37,0$ mil. O valor do primeiro quartil foi de $\mathrm{R} \$ 166,0 \mathrm{mil}$, enquanto os valores do $2^{\circ}$ e $3^{\circ}$ quartis foram de, respectivamente, $\mathrm{R} \$ 376,7$ mil e $\mathrm{R} \$ 587,7$ mil.

O valor médio nominal das Receitas Totais foi de $\mathrm{R} \$ 569,8$ mil, com desvio-padrão de $\mathrm{R} \$$ 507,5 mil. A faixa de valores das Receitas Totais variou de $\mathrm{R} \$ 91,9$ mil a $\mathrm{R} \$ 3.025,6$ mil. O primeiro quartil foi igual a $\mathrm{R} \$ 236,3$ mil, o valor da mediana foi de $\mathrm{R} \$ 436,4$ mil e o $3^{\circ}$ quartil foi de R\$ 765,5 mil.

Conforme apresentado na Tabela 22, o valor médio anual das transferências públicas por residente foi de R\$ 2,3 mil, com desvio-padrão de R\$ 2,0 mil. Algumas ILPIs não se beneficiaram com transferências públicas diretas, assim, a faixa de valores para esse grupo variou de zero a R $\$ 10,9$ mil. O valor do primeiro quartil foi de $\mathrm{R} \$ 1,1$ mil por residente. Os valores do $2^{\circ}$ e do $3^{\circ}$ quartis foram, respectivamente, de $\mathrm{R} \$ 1,9$ mil e 2,8 mil por residente. 
O valor médio anual decorrente da venda de produtos e recebimento de outras transferências privadas foi de $\mathrm{R} \$ 10,2$ mil por residente. O desvio-padrão desse grupo foi de $\mathrm{R} \$ 7,8$ mil. $\mathrm{O}$ menor valor anual recebido por residente foi de $\mathrm{R} \$ 1,3$ mil e o maior valor anual observado foi de $\mathrm{R} \$ 35,7$ mil por residente. $\mathrm{O}$ valor do primeiro quartil foi de $\mathrm{R} \$ 5,0$ mil, enquanto os valores do $2^{\circ}$ e $3^{\circ}$ quartis foram de, respectivamente, $\mathrm{R} \$ 7,9$ mil e $\mathrm{R} \$ 13,0$ mil.

O valor médio das Receitas Totais por residente foi de $\mathrm{R} \$ 12,4$ mil, com desvio-padrão de $\mathrm{R} \$$ 8,0 mil. A faixa de valores das Receitas Totais variou de $\mathrm{R} \$ 3,2$ mil a $\mathrm{R} \$ 38,8$ mil por residente. O primeiro quartil foi igual a $\mathrm{R} \$ 7,5$ mil, o valor da mediana foi de $\mathrm{R} \$ 10,0$ mil e o $3^{\circ}$ quartil foi de R\$14,9 mil.

Tabela 22 - Composição da receita por residente

Statistics

\begin{tabular}{|ll|r|r|r|}
\hline & & \multicolumn{1}{|c|}{$\begin{array}{c}\text { Transf } \\
\text { Pub/res }\end{array}$} & $\begin{array}{c}\text { Tr } \\
\text { Pub+Priv/res }\end{array}$ & Rec Total/res \\
\hline N & Valid & 42 & 42 & 42 \\
Mean & Missing & 0 & 0 & 0 \\
Std. Error of Mean & & 2273,5330 & 10169,6925 & 12443,2255 \\
Median & 314,26610 & 1211,24367 & 1227,67316 \\
Mode & 1866,3315 & 7869,2386 & 9953,0026 \\
Std. Deviation & &, $00^{\mathrm{a}}$ & $1277,45^{\mathrm{a}}$ & $3167,49^{\mathrm{a}}$ \\
Variance & 2036,677 & 7849,75613 & 7956,23142 \\
Range & 4148054 & 61618671,24 & 63301618,49 \\
Minimum & 10888,98 & 34331,94 & 35619,61 \\
Maximum &, 00 & 1277,45 & 3167,49 \\
Sum & & 10888,98 & 35609,39 & 38787,10 \\
Percentiles & 25 & 95488,39 & 427127,09 & 522615,47 \\
& 50 & 1096,8017 & 5044,7867 & 7521,8642 \\
& 75 & 1866,3315 & 7869,2386 & 9953,0026 \\
\hline
\end{tabular}

a. Multiple modes exist. The smallest value is shown 
Tabela 23 - Participação das receitas públicas e privadas

Statistics

\begin{tabular}{|ll|r|r|}
\hline & & Part TrPubli & Part Tr priv \\
\hline N & Valid & 42 & 42 \\
Mean & & 0 & 0 \\
Std. Ersing & 23,2274 & 76,7726 \\
Median & 2,50184 & 2,50184 \\
Mode & 21,2755 & 78,7245 \\
Std. Deviation & &, $00^{\mathrm{a}}$ & $40,18^{\mathrm{a}}$ \\
Variance & 16,21377 & 16,21377 \\
Range & & 262,88621 & 262,88621 \\
Minimum & 59,82 & 59,82 \\
Maximum &, 00 & 40,18 \\
Sum & & 59,82 & 100,00 \\
Percentiles & 25 & 975,55 & 3224,45 \\
& 50 & 11,8999 & 67,6156 \\
& 75 & 21,2755 & 78,7245 \\
\hline
\end{tabular}

a. Multiple modes exist. The smallest value is shown

Considerando-se os valores sobre a composição das receitas, apresentados na Tabela 23, $23,2 \%$ do total foram representados por transferências públicas e $76,8 \%$ foram da participação das receitas privadas. O desvio-padrão dessas participações foi de 16,2\%. Considerando que há ILPIs que não contaram com transferências públicas, a faixa de participação desse grupo foi de zero a 59,8\%. A participação das transferências privadas variou de $40,2 \%$ a $100,0 \%$. Os valores do $1^{\mathrm{o}}$ quartil, representando as transferências públicas e as privadas, foram de, respectivamente, $11,9 \%$ e $67,6 \%$. As medianas foram iguais a $21,3 \%$ e $78,7 \%$ e, para o $3^{\circ}$ quartil, a composição foi de $32,4 \%$ de transferências públicas e $88,1 \%$ privadas. 


\subsubsection{Resultado (receitas - despesas)}

Tabela 24 - Resultado nominal médio por ILPI

Statistics

Rt-Dt nominal
\begin{tabular}{|ll|r|}
\hline $\mathrm{N}$ & Valid & 42 \\
& Missing & 0 \\
Mean & & $-21117,5$ \\
Std. Error of Mean & & 40813,02 \\
Median & & 3329,1350 \\
Mode & & $-833986^{a}$ \\
Std. Deviation & & 264498,6 \\
Variance & & $7,0 \mathrm{E}+10$ \\
Range & & 1520743 \\
Minimum & & -833986 \\
Maximum & & 686757,52 \\
Sum & 25 & -886937 \\
Percentiles & 50 & -171022 \\
& 75 & 3329,1350 \\
& & 99675,51 \\
\hline
\end{tabular}

a. Multiple modes exist. The smallest value is shown

$\mathrm{O}$ valor do resultado nominal, calculado pela diferença entre as receitas totais e as despesas totais, relativo ao exercício de 2008, apresentou um déficit médio de R\$21,1 mil por organização, com desvio-padrão de R $\$ 264,5$ mil. Os resultados observados variaram de uma posição deficitária de $\mathrm{R} \$ 834,0$ mil a um valor superavitário de $\mathrm{R} \$ 686,8$ mil. $\mathrm{O}$ valor do $1^{\circ}$ quartil foi um déficit de $\mathrm{R} \$ 171,0$ mil. A mediana foi de $\mathrm{R} \$ 3,3$ mil e o valor do $3^{\circ}$ quartil foi de 99,7 mil. 
Tabela 25 - Resultado médio por residente

Statistics

Rt-Dt res
\begin{tabular}{|ll|r|}
\hline $\mathrm{N}$ & Valid & 42 \\
& Missing & 0 \\
Mean & & $-441,2951$ \\
Std. Error of Mean & & 844,92500 \\
Median & & 83,9073 \\
Mode & & $-14121,82^{\mathrm{a}}$ \\
Std. Deviation & & 5475,740 \\
Variance & & $3,0 \mathrm{E}+07$ \\
Range & & 26069,48 \\
Minimum & & $-14121,82$ \\
Maximum & & 11947,67 \\
Sum & 25 & $-18534,39$ \\
Percentiles & 50 & $-4019,62$ \\
& 75 & 83,9073 \\
\end{tabular}

a. Multiple modes exist. The smallest value is shown

Considerando-se o resultado por residente, constatou-se um déficit médio anual de R 0,4 mil por organização, com desvio-padrão de $\mathrm{R} \$ 5,5$ mil. O menor resultado observado foi um déficit no exercício de $\mathrm{R} \$ 14,1$ mil, contrastando com o maior superávit apresentado na amostra de $\mathrm{R} \$ 11,9$ mil por residente. $\mathrm{O}$ valor do $1^{\circ}$ quartil foi um déficit de $\mathrm{R} \$ 4,0$ mil, o valor da mediana foi de, aproximadamente, zero, e o valor do $3^{\circ}$ quartil foi um superávit anual de 2,2 mil por residente. 


\subsubsection{Disclosure}

Tabela 26 - Disclosure

Statistics

Discl
\begin{tabular}{|ll|r|}
\hline $\mathrm{N}$ & Valid & 42 \\
& Missing & 0 \\
Mean & & 36,6857 \\
Std. Error of Mean & & 1,49545 \\
Median & & 37,7500 \\
Mode & & $31,00^{\mathrm{a}}$ \\
Std. Deviation & & 9,69163 \\
Variance & & 93,92760 \\
Range & & 37,90 \\
Minimum & & 20,70 \\
Maximum & & 58,60 \\
Sum & & 1540,80 \\
Percentiles & 25 & 30,1500 \\
& 50 & 37,7500 \\
& 75 & 42,2500 \\
\hline
\end{tabular}

a. Multiple modes exist. The smallest value is shown

O valor médio do indicador de disclosure foi de 36,7\%, com desvio-padrão de 9,7\%. Esse nível de disclosure pode ser considerado baixo, principalmente porque as entidades analisadas possuem 10 itens obrigatórios de divulgação dentre os 29 itens que compõem o indicador de disclosure, ou seja, esperava-se que, ao menos, 34,5\% dos itens estivessem presentes nas ILPIs.

A faixa de valores desse indicador variou de $20,7 \%$ a $58,6 \%$. O primeiro quartil foi igual a $30,2 \%$, o valor da mediana foi de $37,8 \%$ e o $3^{\circ}$ quartil foi de $42,3 \%$. Tais dados demonstram o quanto as organizações analisadas estão distantes de uma situação considerada transparente.

Sob a perspectiva institucional, a sobrevivência das ILPIs depende da sua capacidade de adaptação às diversas pressões ambientais. Se nem os itens obrigatórios são atendidos em sua totalidade, então é plausível afirmar que não há mecanismos ativos de pressão de órgãos públicos e da sociedade civil para que existam maiores níveis de transparência e evidenciação das informações das organizações filantrópicas. Essa imobilidade pública justifica o porquê de algumas entidades previamente selecionadas terem se recusado a participar desta pesquisa 
sob a alegação de que não poderiam divulgar dados financeiros, visto que esses dados eram confidenciais, em nítido contraste com a legislação brasileira.

\subsection{Estimativa das eficiências produtivas}

Para o cálculo dos valores representativos da eficiência produtiva, conforme o modelo DEA orientado a inputs e com retornos variáveis de escala, utilizou-se o programa estatístico SIAD $3.0^{\circledR}$.

A base de dados foi formada por 42 DMUs, relacionadas a 9 variáveis (3 inputs e 6 outputs), conforme apresentada na Tabela 27.

A quantidade de DMUs atende ao critério sugerido por Dyson et al. (2001) para que o modelo DEA possua um poder discriminatório aceitável, em que o número de DMUs deve superar, em duas vezes, o produto da quantidade de inputs por outputs. Assim, 42 é maior que o valor obtido pela multiplicação 2 × 3 × 6 .

As 42 DMUs desta pesquisa também superam a quantidade mínima sugerida por GonzalezAraya (2003), com a relação de quatro DMUs por variável $(4$ x $9=36)$. 
Tabela 27 - Variáveis do modelo DEA

\begin{tabular}{|c|c|c|c|c|c|c|c|c|c|}
\hline & \multicolumn{3}{|c|}{ Inputs } & \multicolumn{6}{|c|}{ Outputs } \\
\hline & 1 & 2 & 3 & 1 & 2 & 3 & 4 & 5 & 6 \\
\hline DMU & HMOT/res & AP/res & $\mathrm{DT} / \mathrm{res}$ & 1-Tmort & 1-Tdiar & $1-$ Tescab & 1-Tdesidr & 1-Tulcdec & 1-Tdesnut \\
\hline 1 & 95,0 & $50.134,1$ & $11.390,8$ & 99,0 & 97,0 & 100,0 & 96,8 & 96,0 & 97,2 \\
\hline 2 & 118,1 & $20.468,9$ & $14.104,0$ & 99,1 & 99,2 & 100,0 & 100,0 & 99,3 & 100,0 \\
\hline 3 & 60,9 & $11.690,4$ & $6.980,3$ & 99,0 & 98,0 & 100,0 & 99,0 & 100,0 & 98,2 \\
\hline 4 & 117,3 & $5.526,1$ & $8.201,2$ & 98,3 & 99,6 & 99,3 & 99,4 & 99,9 & 97,0 \\
\hline 5 & 221,7 & $6.506,7$ & $24.979,5$ & 100,0 & 99,0 & 100,0 & 100,0 & 99,9 & 100,0 \\
\hline 6 & 107,8 & $10.954,1$ & $13.793,1$ & 99,0 & 99,0 & 100,0 & 99,0 & 100,0 & 100,0 \\
\hline 7 & 64,4 & $2.815,7$ & $5.223,5$ & 97,6 & 99,0 & 99,2 & 100,0 & 97,6 & 97,6 \\
\hline 8 & 80,5 & $33.451,2$ & $8.300,3$ & 99,0 & 98,5 & 99,4 & 99,2 & 99,3 & 98,9 \\
\hline 9 & 443,4 & $173.831,3$ & $46.500,8$ & 98,7 & 99,2 & 99,8 & 99,7 & 99,6 & 100,0 \\
\hline 10 & 102,9 & $3.090,9$ & $9.555,6$ & 98,8 & 99,8 & 98,3 & 99,4 & 99,2 & 98,2 \\
\hline 11 & 78,4 & $1.355,5$ & $9.497,2$ & 98,5 & 98,0 & 99,8 & 97,0 & 97,0 & 100,0 \\
\hline 12 & 77,3 & $3.951,2$ & $8.263,2$ & 98,9 & 99,0 & 99,4 & 100,0 & 99,9 & 100,0 \\
\hline 13 & 92,1 & $7.452,0$ & $10.470,1$ & 98,1 & 97,0 & 98,0 & 97,0 & 99,0 & 98,0 \\
\hline 14 & 79,3 & $2.679,4$ & $7.490,7$ & 99,4 & 99,8 & 99,2 & 99,1 & 99,0 & 99,2 \\
\hline 15 & 92,7 & $4.806,7$ & $7.713,8$ & 98,8 & 99,6 & 99,8 & 99,2 & 99,0 & 98,8 \\
\hline 16 & 121,2 & $2.706,9$ & $13.329,0$ & 99,0 & 99,0 & 100,0 & 98,0 & 98,0 & 100,0 \\
\hline 17 & 57,4 & $2.226,4$ & $5.117,2$ & 98,2 & 97,6 & 97,6 & 98,4 & 96,9 & 98,8 \\
\hline 18 & 83,7 & $39.548,9$ & $10.633,4$ & 98,5 & 99,0 & 99,9 & 100,0 & 99,0 & 98,7 \\
\hline 19 & 89,7 & $1.600,0$ & $8.032,0$ & 97,4 & 97,8 & 99,9 & 100,0 & 100,0 & 98,0 \\
\hline 20 & 95,0 & 766,0 & $1.567,9$ & 99,4 & 98,1 & 98,6 & 98,0 & 100,0 & 96,9 \\
\hline 21 & 132,8 & $82.786,4$ & $19.189,7$ & 99,3 & 99,7 & 100,0 & 100,0 & 100,0 & 99,8 \\
\hline 22 & 96,5 & $94.496,7$ & $11.982,5$ & 100,0 & 99,7 & 99,8 & 98,6 & 98,0 & 99,8 \\
\hline 23 & 45,0 & $7.135,8$ & $6.232,3$ & 98,8 & 95,1 & 99,5 & 95,5 & 95,2 & 94,5 \\
\hline 24 & 208,0 & $5.165,7$ & 655,0 & 98,6 & 97,8 & 100,0 & 97,2 & 97,1 & 95,4 \\
\hline 25 & 311,3 & $25.800,9$ & $30.443,6$ & 100,0 & 97,2 & 100,0 & 98,8 & 98,0 & 98,0 \\
\hline 26 & 84,2 & $2.647,0$ & $7.044,3$ & 99,5 & 98,5 & 98,6 & 97,9 & 96,7 & 98,5 \\
\hline 27 & 89,8 & $139.122,9$ & $52.908,9$ & 99,5 & 99,5 & 99,5 & 99,0 & 99,0 & 99,5 \\
\hline 28 & 196,3 & $23.950,1$ & $18.148,8$ & 98,7 & 99,1 & 99,7 & 100,0 & 99,7 & 100,0 \\
\hline 29 & 188,4 & $6.505,9$ & $4.274,4$ & 98,8 & 97,2 & 96,6 & 99,8 & 97,9 & 96,5 \\
\hline 30 & 129,5 & $12.593,5$ & $25.564,5$ & 100,0 & 99,4 & 100,0 & 98,9 & 98,0 & 98,4 \\
\hline 31 & 159,6 & $2.554,7$ & $10.227,1$ & 98,0 & 97,0 & 97,0 & 96,0 & 98,0 & 98,0 \\
\hline 32 & 190,5 & $21.317,9$ & $16.944,1$ & 99,0 & 100,0 & 100,0 & 97,7 & 98,2 & 99,1 \\
\hline 33 & 81,9 & $2.070,5$ & $4.553,5$ & 97,6 & 99,0 & 99,9 & 97,8 & 99,3 & 100,0 \\
\hline 34 & 153,0 & $77.570,0$ & $17.806,5$ & 97,8 & 98,2 & 99,9 & 100,0 & 96,3 & 97,0 \\
\hline 35 & 111,5 & $29.672,3$ & $8.002,5$ & 99,0 & 98,8 & 100,0 & 100,0 & 100,0 & 96,8 \\
\hline 36 & 72,9 & $3.653,6$ & $10.332,8$ & 99,1 & 98,9 & 99,5 & 96,6 & 100,0 & 99,6 \\
\hline 37 & 86,6 & 924,6 & $6.839,7$ & 99,7 & 95,1 & 100,0 & 97,0 & 97,2 & 100,0 \\
\hline 38 & 208,0 & $2.884,1$ & $8.567,1$ & 97,8 & 99,0 & 98,0 & 97,1 & 97,6 & 99,0 \\
\hline 39 & 179,6 & $4.680,0$ & $9.561,0$ & 99,0 & 97,7 & 99,4 & 99,4 & 98,3 & 97,2 \\
\hline 40 & 204,1 & $1.644,2$ & $3.598,3$ & 100,0 & 94,1 & 100,0 & 100,0 & 100,0 & 98,6 \\
\hline 41 & 122,1 & $5.355,9$ & $9.808,6$ & 99,6 & 99,8 & 99,0 & 99,0 & 99,1 & 98,9 \\
\hline 42 & 155,1 & $4.214,5$ & $27.321,1$ & 99,0 & 99,8 & 99,8 & 98,2 & 98,9 & 99,0 \\
\hline
\end{tabular}

Além do cálculo da fronteira padrão de eficiência, neste trabalho também foi calculada a fronteira invertida e o grau de eficiência composta, aumentando o poder de discriminação entre as DMUs. 
Tabela 28 - Eficiência composta

\begin{tabular}{|c|c|c|c|c|c|}
\hline \multicolumn{6}{|c|}{ EFICIÊNCIA DEA } \\
\hline DMU & Padrão & Invertida & Composta & Composta* & Ranking \\
\hline 1 & 0,64130 & 1,00000 & 0,32065 & 0,35618 & 39 \\
\hline 2 & 1,00000 & 0,31469 & 0,84266 & 0,93603 & 6 \\
\hline 3 & 1,00000 & 0,20607 & 0,89696 & 0,99636 & 2 \\
\hline 4 & 1,00000 & 0,52355 & 0,73822 & 0,82003 & 17 \\
\hline 5 & 1,00000 & 0,55181 & 0,72410 & 0,80433 & 19 \\
\hline 6 & 1,00000 & 0,32565 & 0,83717 & 0,92994 & 7 \\
\hline 7 & 1,00000 & 1,00000 & 0,50000 & 0,55540 & 26 \\
\hline 8 & 0,85908 & 0,25349 & 0,80279 & 0,89175 & 10 \\
\hline 9 & 1,00000 & 1,00000 & 0,50000 & 0,55540 & 27 \\
\hline 10 & 1,00000 & 0,36712 & 0,81644 & 0,90691 & 9 \\
\hline 11 & 1,00000 & 0,52038 & 0,73981 & 0,82179 & 16 \\
\hline 12 & 1,00000 & 0,19951 & 0,90025 & 1,00000 & 1 \\
\hline 13 & 0,71031 & 0,84976 & 0,43027 & 0,47795 & 37 \\
\hline 14 & 1,00000 & 0,21676 & 0,89162 & 0,99042 & 3 \\
\hline 15 & 1,00000 & 0,24439 & 0,87781 & 0,97507 & 4 \\
\hline 16 & 1,00000 & 0,43508 & 0,78246 & 0,86916 & 12 \\
\hline 17 & 1,00000 & 1,00000 & 0,50000 & 0,55540 & 28 \\
\hline 18 & 1,00000 & 0,29878 & 0,85061 & 0,94486 & 5 \\
\hline 19 & 1,00000 & 1,00000 & 0,50000 & 0,55540 & 29 \\
\hline 20 & 1,00000 & 0,40821 & 0,79590 & 0,88409 & 11 \\
\hline 21 & 1,00000 & 0,49345 & 0,75327 & 0,83674 & 15 \\
\hline 22 & 1,00000 & 0,80341 & 0,59830 & 0,66459 & 24 \\
\hline 23 & 1,00000 & 1,00000 & 0,50000 & 0,55540 & 30 \\
\hline 24 & 1,00000 & 1,00000 & 0,50000 & 0,55540 & 31 \\
\hline 25 & 0,53516 & 1,00000 & 0,26758 & 0,29723 & 41 \\
\hline 26 & 1,00000 & 0,60598 & 0,69701 & 0,77424 & 20 \\
\hline 27 & 1,00000 & 1,00000 & 0,50000 & 0,55540 & 32 \\
\hline 28 & 1,00000 & 0,46029 & 0,76985 & 0,85516 & 14 \\
\hline 29 & 1,00000 & 1,00000 & 0,50000 & 0,55540 & 33 \\
\hline 30 & 1,00000 & 0,69600 & 0,65200 & 0,72425 & 22 \\
\hline 31 & 0,50266 & 1,00000 & 0,25133 & 0,27918 & 42 \\
\hline 32 & 1,00000 & 0,69404 & 0,65298 & 0,72534 & 21 \\
\hline 33 & 1,00000 & 1,00000 & 0,50000 & 0,55540 & 34 \\
\hline 34 & 0,55319 & 1,00000 & 0,27659 & 0,30724 & 40 \\
\hline 35 & 1,00000 & 0,44966 & 0,77517 & 0,86106 & 13 \\
\hline 36 & 1,00000 & 0,52782 & 0,73609 & 0,81766 & 18 \\
\hline 37 & 1,00000 & 0,81135 & 0,59432 & 0,66018 & 25 \\
\hline 38 & 0,66655 & 1,00000 & 0,33328 & 0,37021 & 38 \\
\hline 39 & 0,57362 & 0,65522 & 0,45920 & 0,51008 & 36 \\
\hline 40 & 1,00000 & 1,00000 & 0,50000 & 0,55540 & 35 \\
\hline 41 & 1,00000 & 0,34792 & 0,82604 & 0,91758 & 8 \\
\hline 42 & 1,00000 & 0,73474 & 0,63263 & 0,70273 & 23 \\
\hline
\end{tabular}

Os resultados são os apresentados na Tabela 28. A DMU $\mathrm{n}^{\circ} 12$ foi considerada a mais eficiente $(100,0 \%)$. Em sentido oposto, a DMU n 31 foi a ILPI que apresentou o menor grau de eficiência $(27,9 \%)$. Do total das observações, 20 ILPIs apresentaram níveis de eficiência acima de 75\%, 16 ILPIs apresentaram graus de eficiência entre 50\% e 75\% e 6 entidades apresentaram graus de eficiência inferiores a $50 \%$. 


\subsubsection{Correlação entre eficiência e tipos de dependência}

Tabela 29 - Correlação entre eficiência e quantidade de residentes, por tipo.

Correlations

\begin{tabular}{|ll|r|r|r|r|}
\hline & & Efic_DEA & res G1 & res G2 & res G3 \\
\hline Efic_DEA & Pearson Correlation & 1 &, 087 &,- 066 &,- 128 \\
& Sig. (2-tailed) &, &, 586 &, 676 &, 420 \\
& $\mathrm{~N}$ & 42 & 42 & 42 & 42 \\
\hline res G1 & Pearson Correlation &, 087 & 1 &, $543^{* *}$ &, $320^{*}$ \\
& Sig. (2-tailed) &, 586 &, &, 000 &, 039 \\
& $\mathrm{~N}$ & 42 & 42 & 42 & 42 \\
\hline res G2 & Pearson Correlation &,- 066 &, $543^{* *}$ & 1 &, $664^{*}$ \\
& Sig. (2-tailed) &, 676 &, 000 &, &, 000 \\
& $\mathrm{~N}$ & 42 & 42 & 42 & 42 \\
\hline res G3 & Pearson Correlation &,- 128 &, $320^{*}$ &, $664^{* *}$ & 1 \\
& Sig. (2-tailed) &, 420 &, 039 &, 000 &, \\
& $\mathrm{~N}$ & 42 & 42 & 42 & 42 \\
\hline
\end{tabular}

${ }^{* *}$. Correlation is significant at the 0.01 level (2-tailed).

*. Correlation is significant at the 0.05 level (2-tailed).

Na Tabela 29, observa-se que os valores de eficiência calculados pelo modelo DEA-BCC input não apresentam relação significativa com a quantidade de residentes por grau de dependência, assim como não foram constatados valores correlacionais significativos entre a eficiência DEA e a proporção de residente (também por grau de dependência), conforme apresentado na Tabela 30 .

Tabela 30 - Correlação entre eficiência e distribuição de residentes, por tipo.

\begin{tabular}{|ll|r|r|r|r|}
\hline \multicolumn{7}{|c|}{ Correlations } \\
\hline & & Efic_DEA & Part \% G1 & Part \% G2 & Part \% G3 \\
\hline Efic_DEA & Pearson Correlation & 1 &, 217 &,- 111 &,- 199 \\
& Sig. (2-tailed) &, &, 168 &, 483 &, 208 \\
& $\mathrm{~N}$ & 42 & 42 & 42 & 42 \\
\hline Part \% G1 & Pearson Correlation &, 217 & 1 &,$- 719^{* *}$ &,$- 712^{\star *}$ \\
& Sig. (2-tailed) &, 168 &, &, 000 &, 000 \\
& $\mathrm{~N}$ & 42 & 42 & 42 & 42 \\
\hline Part \% G2 & Pearson Correlation &,- 111 &,$- 719^{* *}$ & 1 &, 025 \\
& Sig. (2-tailed) &, 483 &, 000 &, &, 876 \\
& $\mathrm{~N}$ & 42 & 42 & 42 & 42 \\
\hline Part \% G3 & Pearson Correlation &,- 199 &,$- 712^{\star *}$ &, 025 & 1 \\
& Sig. (2-tailed) &, 208 &, 000 &, 876 &, \\
& $\mathrm{~N}$ & 42 & 42 & 42 & 42 \\
\hline
\end{tabular}

${ }^{* *}$. Correlation is significant at the 0.01 level (2-tailed). 


\subsection{Alvos}

Os alvos do modelo BCC orientado aos insumos são calculados com base na fronteira padrão de eficiência. Conforme apresentado no Apêndice 3, cada DMU foi listada com seus respectivos valores-alvo. 34 DMUs foram classificadas como eficientes pela fronteira padrão e não possuem valores-alvo, pois já são eficientes, mas 8 DMUs $\left(n^{\circ}\right.$ s $1,8,13,25,31,34,38$ e 39) apresentaram referências para o aprimoramento da eficiência. Com exceção da DMU no 8 , que apresentou o $10^{\circ}$ melhor grau de eficiência pelo cálculo composto, as demais 7 unidades foram classificadas como aquelas que apresentaram os níveis mais baixos de eficiência pelo cálculo composto, ocupando da $36^{\mathrm{a}}$ até a $42^{\mathrm{a}}$ posição no ranking da Tabela 28.

Os valores atuais, os alvos e as respectivas diferenças das DMUs com menor grau de eficiência são apresentados nas tabelas a seguir.

Tabela 31 - Valores atuais de inputs e outputs das ILPIs ineficientes

\begin{tabular}{|l|rrrrrrrr|}
\hline \multicolumn{7}{|c|}{ Valores atuais } \\
\hline Variáveis & DMU 1 & \multicolumn{1}{c|}{ DMU 8 } & DMU 13 & DMU 25 & DMU 31 & DMU 34 & DMU 38 & DMU 39 \\
\hline Input_1 & 95,00 & 80,45 & 92,05 & 311,32 & 159,57 & 153,00 & 208,00 & 179,64 \\
Input_2 & $50.134,13$ & $33.451,18$ & $7.451,98$ & $25.800,94$ & $2.554,75$ & $77.569,98$ & $2.884,14$ & $4.680,02$ \\
Input_3 & $11.390,76$ & $8.300,25$ & $10.470,15$ & $30.443,61$ & $10.227,10$ & $17.806,45$ & $8.567,10$ & $9.560,98$ \\
Output_1 & 99,00 & 99,02 & 98,10 & 100,00 & 98,00 & 97,75 & 97,80 & 99,00 \\
Output_2 & 97,00 & 98,49 & 97,00 & 97,19 & 97,00 & 98,20 & 99,00 & 97,70 \\
Output_3 & 100,00 & 99,40 & 98,00 & 100,00 & 97,00 & 99,88 & 98,00 & 99,40 \\
Output_4 & 96,80 & 99,18 & 97,00 & 98,80 & 96,00 & 100,00 & 97,10 & 99,40 \\
Output_5 & 96,00 & 99,33 & 99,00 & 98,00 & 98,00 & 96,30 & 97,58 & 98,30 \\
Output 6 & 97,20 & 98,87 & 98,00 & 98,00 & 98,00 & 97,02 & 99,00 & 97,20 \\
\hline
\end{tabular}

Tabela 32 - Alvos de inputs e outputs das ILPIs ineficientes

\begin{tabular}{|l|rrrrrrrr|}
\hline \multicolumn{7}{|c|}{ Alvos } \\
\hline Variáveis & \multicolumn{1}{|c|}{ DMU 1 } & DMU 8 & DMU 13 & DMU 25 & DMU 31 & DMU 34 & DMU 38 & DMU 39 \\
\hline Input_1 & 60,92 & 69,12 & 65,38 & 161,00 & 80,21 & 84,64 & 84,41 & 103,04 \\
Input_2 & $11.690,41$ & $6.853,83$ & $5.293,18$ & $7.971,61$ & $1.284,17$ & $29.302,06$ & $1.922,43$ & $2.684,54$ \\
Input_3 & $6.980,29$ & $7.130,59$ & $7.437,00$ & $16.292,16$ & $4.838,23$ & $9.850,25$ & $4.659,93$ & $5.484,34$ \\
Output_1 & 99,04 & 99,02 & 98,81 & 100,00 & 99,07 & 98,21 & 98,55 & 99,00 \\
Output_2 & 98,00 & 98,60 & 98,19 & 97,19 & 97,00 & 98,71 & 99,00 & 97,70 \\
Output_3 & 100,00 & 99,45 & 99,01 & 100,00 & 98,83 & 99,88 & 99,37 & 99,40 \\
Output_4 & 99,00 & 99,18 & 97,89 & 99,38 & 97,72 & 100,00 & 98,22 & 99,40 \\
Output_5 & 100,00 & 99,48 & 99,00 & 98,84 & 98,00 & 99,20 & 99,40 & 99,11 \\
Output_6 & 98,20 & 98,87 & 98,87 & 98,46 & 98,65 & 98,50 & 99,00 & 98,57 \\
\hline
\end{tabular}


Tabela 33 - Diferenças entre os valores atuais e os alvos das ILPIs ineficientes

\begin{tabular}{|l|rrrrrrrr|}
\hline \multicolumn{10}{|c|}{ Diferenças } \\
\hline Variáveis & DMU 1 & DMU 8 & DMU 13 & DMU 25 & DMU 31 & DMU 34 & DMU 38 & DMU 39 \\
\hline Input_1 & $(34,08)$ & $(11,34)$ & $(26,67)$ & $(150,32)$ & $(79,36)$ & $(68,36)$ & $(123,59)$ & $(76,59)$ \\
Input_2 & $(38.443,72)$ & $(26.597,35)$ & $(2.158,80)$ & $(17.829,34)$ & $(1.270,58)$ & $(48.267,92)$ & $(961,71)$ & $(1.995,48)$ \\
Input_3 & $(4.410,47)$ & $(1.169,66)$ & $(3.033,15)$ & $(14.151,45)$ & $(5.388,87)$ & $(7.956,20)$ & $(3.907,16)$ & $(4.076,64)$ \\
Output_1 & 0,04 & - & 0,71 & - & 1,07 & 0,46 & 0,75 & - \\
Output_2 & 1,00 & 0,12 & 1,19 & - & - & 0,51 & - & - \\
Output_3 & - & 0,05 & 1,01 & - & 1,83 & - & 1,37 & - \\
Output_4 & 2,20 & - & 0,89 & 0,58 & 1,72 & - & 1,12 & - \\
Output_5 & 4,00 & 0,16 & - & 0,84 & - & 2,90 & 1,82 & 0,81 \\
Output 6 & 1,00 & - & 0,87 & 0,46 & 0,65 & 1,48 & - & 1,37 \\
\hline
\end{tabular}

Os alvos indicam o quanto a DMU poderia reduzir o consumo de insumos para atingir um maior nível de eficiência.

Pela análise das diferenças entre os valores projetados como alvos e os valores atuais, o input 1 , representando as horas totais por residente, está sendo consumido, proporcionalmente, em maior quantidade na DMU 25, seguido pela DMU 38. A análise comparativa entre as unidades pode sugerir que as respectivas DMUs estão com excesso de horas trabalhadas sem reflexos significativos nos indicadores de desempenho. Pautando-se pela referência de outras unidades mais eficientes, a DMU 25 poderia reduzir em 150,32 horas mensais trabalhadas por residente. Nesse sentido, a DMU 38 poderia reduzir o consumo de horas trabalhadas em 123,59 horas mensais por residente. Dentre essas entidades, a DMU 8 seria aquela que menos horas trabalhadas $(11,34)$ necessitaria reduzir para melhorar seu grau de eficiência, mantendose inalteradas as demais variáveis.

Com relação ao input 2 (valor do Ativo Permanente por residente), as DMUs no 34 e $n^{\circ} 1$ são aquelas que, proporcionalmente, encontram-se em situação mais ineficiente, em que poderiam reduzir o valor dessa variável em relação a esse grupo contábil por residente em $\mathrm{R} \$ 48.287,92$ e R\$38.443,72, respectivamente. O valor do Ativo Permanente, ligado ao fator Capital, pode estar superdimensionado nas DMUs em questão, sem afetar, proporcionalmente, os indicadores de desempenho. A DMU no 38 é aquela que, para o input 2, menos necessitaria reduzir essa relação $(\mathrm{R} \$ 961,71)$.

A DMU $n^{0} 25$ é aquela que mais necessitaria rever a relação das Despesas Totais por residentes (input 3), podendo reduzi-la em R\$14.151,55 para aumentar o seu grau de eficiência. A entidade que menos necessita reduzir esse input é a DMU $\mathrm{n}^{\circ} 8$, no valor de $\mathrm{R} \$$ 
1.169,66. O excesso de consumo nesse item pode significar que a ILPI possui gastos sem reflexos significativos nos indicadores de desempenho.

\subsection{Teste das hipóteses}

As hipóteses direcionadoras deste trabalho foram:

○ H1: Quanto maior o grau de dependência por recursos públicos, menor é o nível de eficiência produtiva das instituições filantrópicas de longa permanência para idosos do Estado de São Paulo.

○ H2: Quanto maior o resultado financeiro (receitas - despesas), maior é o nível de eficiência produtiva das instituições filantrópicas de longa permanência para idosos do Estado de São Paulo.

○ H3: Quanto maior o nível de disclosure, maior é o nível de eficiência produtiva das instituições filantrópicas de longa permanência para idosos do Estado de São Paulo.

Assim, para se testar H1, H2 e H3 foram realizadas análises de regressão linear, considerando a eficiência produtiva como a variável dependente, conforme apresentado a seguir.

\subsubsection{Análises de regressão linear}

Conforme Gujarati (2006), a análise de regressão se ocupa do estudo da dependência estatística de uma variável em relação a uma ou mais variáveis explanatórias.

O modelo de análise de regressão, apresentado a seguir, foi utilizado para verificar a possível relação entre as variáveis em estudo e o nível de eficiência produtiva das organizações filantrópicas paulistas de longa permanência para idosos.

$$
E P_{D M U n}=\beta_{0}+\beta_{1} V A R_{D M U n}+u, \quad \mathrm{DMUn}=1,2, \ldots, 42 .
$$

Em que: 
$\mathrm{EP}=$ valor da eficiência produtiva da DMUn, calculado pelo modelo DEA;

$\beta_{0}=$ coeficiente constante;

$\mathrm{VAR}=$ variável em estudo;

$\mathrm{u}=$ termo de erro.

Os pressupostos da análise de regressão linear simples são:

a) Normalidade dos resíduos;

b) Homoscedasticidade dos resíduos;

c) Linearidade dos coeficientes;

d) Ausência de autocorrelação serial nos resíduos.

Os cálculos e testes necessários do modelo de regressão foram realizados com a utilização do programa Statistical Package for the Social Sciences - SPSS. A variável dependente, considerada em todas as análises, foi a eficiência composta, proposta por Leta et al. (2005), calculada pelo modelo DEA BCC com orientação a inputs.

Inicialmente, testou-se a significância do modelo de regressão linear, através da Análise de Variância (Anova), para verificar se o coeficiente de determinação $\left(\mathrm{R}^{2}\right)$ era estatisticamente diferente de zero. O modelo foi considerado válido se o resultado obtido pelo teste de significância $\mathrm{F}$ fosse igual ou inferior ao valor 0,05 , dado um grau de confiança de $95 \%$. Caso contrário, com valores de $\mathrm{F}$ superiores a 0,05 , o modelo foi classificado como não significativo, pois o coeficiente de determinação $\left(\mathrm{R}^{2}\right)$ poderia assumir o valor zero e não explicar a variável dependente. Os testes sobre os pressupostos da análise de regressão linear foram realizados somente para os modelos validados pela Anova.

Utilizou-se o teste de Kolmogorov-Smirnov para se verificar o pressuposto da normalidade, partindo-se da hipótese nula de que a distribuição da série analisada era normal.

Para se avaliar o comportamento dos resíduos gerados pelo modelo de regressão linear utilizou-se o teste de Pesaran-Pesaran, cuja hipótese nula foi que a variância dos resíduos padronizados manteve-se constante (homoscedasticidade). 
Assumiu-se o pressuposto da ausência de autocorrelação serial entre os resíduos, de maneira que o efeito de uma observação de dada variável independente não influencia as observações seguintes. Igualmente, assumiu-se o pressuposto da linearidade entre os coeficientes.

Os resultados apresentados nas seções a seguir foram gerados, diretamente, pelo programa SPSS.

\subsubsection{Transferências públicas}

As análises que envolvem as transferências públicas recebidas pelas ILPIs vinculam-se ao teste da hipótese H1, objetivando-se verificar se o nível de eficiência dessas organizações possui relação significativa com o grau de dependência por recursos de origem estatal. As análises consideraram como variáveis independentes o valor nominal, assim como o valor por residente e a participação relativa das transferências públicas na receita total.

\subsubsection{Valor nominal das transferências públicas}

\section{Descriptive Statistics}

\begin{tabular}{|l|r|r|r|}
\hline & \multicolumn{1}{|c|}{ Mean } & Std. Deviation & \multicolumn{1}{c|}{$\mathrm{N}$} \\
\hline Efic_DEA & 70,1485 & 21,20160 & 42 \\
Transf Publica & 99995,49 & 113894,57526 & 42 \\
\hline
\end{tabular}

\section{Correlations}

\begin{tabular}{|ll|r|r|}
\hline & & Transf \\
Pearson Correlation & Efic_DEA & 1,000 & \multicolumn{1}{c|}{$\begin{array}{c}\text { Publica } \\
\end{array}$} \\
& Transf Publica &, 253 & 1,000 \\
\hline Sig. (1-tailed) & Efic_DEA &, &, 053 \\
& Transf Publica &, 053 &, \\
\hline N & Efic_DEA & 42 & 42 \\
& Transf Publica & 42 & 42 \\
\hline
\end{tabular}




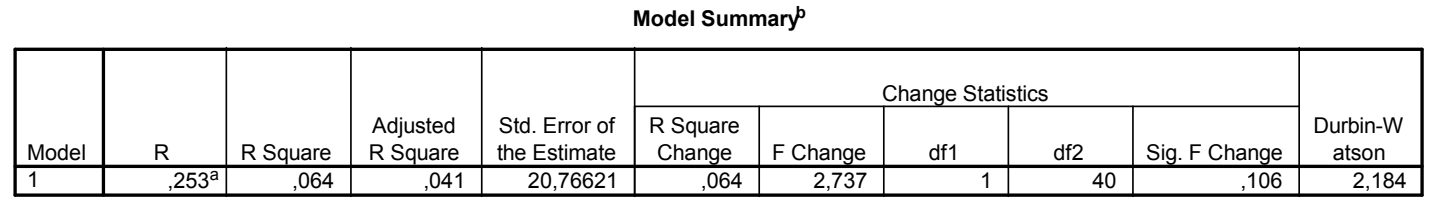

a. Predictors: (Constant), Transf Publica

b. Dependent Variable: Efic_DEA

ANOVA

\begin{tabular}{|ll|r|r|r|r|r|}
\hline \multicolumn{1}{|c|}{} & \multicolumn{1}{c|}{$\begin{array}{c}\text { Sum of } \\
\text { Model }\end{array}$} & Squares & df & Mean Square & F & Sig. \\
\hline 1 & Regression & 1180,404 & 1 & 1180,404 & 2,737 &, $106^{\text {a }}$ \\
& Residual & 17249,414 & 40 & 431,235 & & \\
& Total & 18429,818 & 41 & & & \\
\hline
\end{tabular}

a. Predictors: (Constant), Transf Publica

b. Dependent Variable: Efic_DEA

Considerando-se um grau de confiança de 95\%, a análise de variância (Anova) aponta que a variável independente (valor nominal das Transferências Públicas) não explica as variações da Eficiência DEA (variável dependente), conforme observado pelo teste de significância de F $(>0,5)$, indicando que o coeficiente de determinação $\left(\mathrm{R}^{2}\right)$ pode ser igual a zero. Assim, o modelo de regressão linear analisado não é significativo sob o enfoque estatístico.

\subsubsection{Transferências públicas por residente}

Descriptive Statistics

\begin{tabular}{|l|c|r|r|}
\hline & \multicolumn{1}{|c|}{ Mean } & Std. Deviation & \multicolumn{1}{c|}{$\mathrm{N}$} \\
\hline Efic_DEA & 70,1485 & 21,20160 & 42 \\
Transf Pub/res & 2273,5330 & 2036,67709 & 42 \\
\hline
\end{tabular}

\section{Correlations}

\begin{tabular}{|ll|r|r|}
\hline & & \multicolumn{1}{|c|}{$\begin{array}{c}\text { Transf } \\
\text { Pub/res }\end{array}$} \\
\hline Pearson Correlation & Efic_DEA & 1,000 &, 246 \\
& Transf Pub/res &, 246 & 1,000 \\
\hline Sig. (1-tailed) & Efic_DEA &, &, 058 \\
& Transf Pub/res &, 058 &, \\
\hline $\mathrm{N}$ & Efic_DEA & 42 & 42 \\
& Transf Pub/res & 42 & 42 \\
\hline
\end{tabular}


ANOVA

\begin{tabular}{|ll|r|r|r|r|r|}
\hline \multicolumn{1}{|l|}{} & & Sum of & & & & \\
\hline 1 & Squares & df & Mean Square & F & Sig. \\
\hline & Regression & 1118,401 & 1 & 1118,401 & 2,584 &, $116^{\text {a }}$ \\
& Residual & 17311,417 & 40 & 432,785 & & \\
& Total & 18429,818 & 41 & & & \\
\hline
\end{tabular}

a. Predictors: (Constant), Transf Pub/res

b. Dependent Variable: Efic_DEA

Considerando-se um grau de confiança de 95\%, a análise de variância (Anova) aponta que a variável independente (valor das Transferências Públicas por residente) não explica as variações da Eficiência DEA (variável dependente), conforme observado pelo teste de significância de $\mathrm{F}(>0,5)$, indicando que o coeficiente de determinação $\left(\mathrm{R}^{2}\right)$ pode ser igual a zero. Assim, o modelo de regressão linear analisado não é significativo sob o enfoque estatístico.

\subsubsection{Proporção das transferências públicas}

\section{Descriptive Statistics}

\begin{tabular}{|l|l|r|r|}
\hline & Mean & Std. Deviation & \multicolumn{1}{|c|}{ N } \\
\hline Efic_DEA & 70,1485 & 21,20160 & 42 \\
Part TrPubli & 23,2274 & 16,21377 & 42 \\
\hline
\end{tabular}

\section{Correlations}

\begin{tabular}{|ll|r|r|}
\hline & & Efic DEA & Part TrPubli \\
\hline Pearson Correlation & Efic_DEA & 1,000 &,- 099 \\
& Part TrPubli &,- 099 & 1,000 \\
\hline Sig. (1-tailed) & Efic_DEA &, &, 266 \\
& Part TrPubli &, 266 &, \\
\hline N & Efic_DEA & 42 & 42 \\
& Part TrPubli & 42 & 42 \\
\hline
\end{tabular}


ANOVA

\begin{tabular}{|ll|r|r|r|r|r|}
\hline \multicolumn{1}{|c|}{} & \multicolumn{1}{|c|}{ Sum of } & & & & \\
\hline 1 & Squares & df & Mean Square & F & Sig. \\
\hline & Regression & 181,620 & 1 & 181,620 &, 398 &, $532^{\mathrm{a}}$ \\
& Residual & 18248,198 & 40 & 456,205 & & \\
& Total & 18429,818 & 41 & & & \\
\hline
\end{tabular}

a. Predictors: (Constant), Part TrPubli

b. Dependent Variable: Efic_DEA

Considerando-se um grau de confiança de 95\%, a análise de variância (Anova) aponta que a variável independente (Participação das Transferências Públicas) não explica as variações da Eficiência DEA (variável dependente), conforme observado pelo teste de significância de $\mathrm{F}$ $(>0,5)$, indicando que o coeficiente de determinação $\left(\mathrm{R}^{2}\right)$ pode ser igual a zero. Assim, o modelo de regressão linear analisado não é significativo sob o enfoque estatístico.

Diante desses resultados, não se pode afirmar que as ILPIs filantrópicas paulistas que apresentam maior proporção de recursos públicos no total das receitas obtidas sejam, estatisticamente, menos eficientes do que as organizações que se encontram em situações de menor dependência por transferências financeiras do Estado. Tal fato estimula a reflexão sobre a validade da aplicação dos conceitos da Soft Budget Constraint em organizações asilares filantrópicas, mas também não permite afirmar que as organizações mais dependentes por recursos públicos sejam incentivadas pelas agências governamentais a apresentarem um desempenho mais favorável com relação às demais ILPIs.

\subsubsection{Receitas próprias e transferências privadas}

Apesar das análises sobre possíveis relacionamentos entre a eficiência e os valores totais das receitas próprias e das transferências privadas das ILPIs não se vincularem diretamente ao teste das hipóteses direcionadoras deste trabalho, elas ligam-se à proposta de discussão conceitual sobre a avaliação dessas entidades, por isso são apresentadas a seguir. 


\subsubsection{Valor nominal das receitas próprias e transferências privadas}

Descriptive Statistics

\begin{tabular}{|l|c|r|r|}
\hline & \multicolumn{1}{|c|}{ Mean } & Std. Deviation & \multicolumn{1}{c|}{$\mathrm{N}$} \\
\hline Efic_DEA & 70,1485 & 21,20160 & 42 \\
Transf Prop+Priv & 469813,4 & 494196,16792 & 42 \\
\hline
\end{tabular}

\section{Correlations}

\begin{tabular}{|ll|r|r|}
\hline & & \multicolumn{1}{|c|}{$\begin{array}{c}\text { Transf } \\
\text { Prop+Priv }\end{array}$} \\
\hline Pearson Correlation & Efic_DEA & 1,000 &,- 039 \\
& Transf Prop+Priv &,- 039 & 1,000 \\
\hline Sig. (1-tailed) & Efic_DEA &, &, 402 \\
& Transf Prop+Priv &, 402 &, \\
\hline $\mathrm{N}$ & Efic_DEA & 42 & 42 \\
& Transf Prop+Priv & 42 & 42 \\
\hline
\end{tabular}

ANOVA

\begin{tabular}{|ll|r|r|r|r|r|}
\hline \multicolumn{1}{|c|}{} & \multicolumn{1}{|c|}{$\begin{array}{c}\text { Sum of } \\
\text { Sodel }\end{array}$} & Squares & df & Mean Square & F & Sig. \\
\hline 1 & Regression & 28,638 & 1 & 28,638 &, 062 &, $804^{\text {a }}$ \\
& Residual & 18401,181 & 40 & 460,030 & & \\
& Total & 18429,818 & 41 & & & \\
\hline
\end{tabular}

a. Predictors: (Constant), Transf Prop+Priv

b. Dependent Variable: Efic_DEA

Considerando-se um grau de confiança de 95\%, a análise de variância (Anova) aponta que a variável independente (valor nominal das Receitas Próprias + Transferências Privadas) não explica as variações da Eficiência DEA (variável dependente), conforme observado pelo teste de significância de $\mathrm{F}(>0,5)$, indicando que o coeficiente de determinação $\left(\mathrm{R}^{2}\right)$ pode ser igual a zero. Assim, o modelo de regressão linear analisado não é significativo sob o enfoque estatístico. 


\subsubsection{Receitas próprias e transferências privadas por residente}

\section{Descriptive Statistics}

\begin{tabular}{|l|r|r|r|}
\hline & \multicolumn{1}{|c|}{ Mean } & Std. Deviation & \multicolumn{1}{|c|}{ N } \\
\hline Efic_DEA & 70,1485 & 21,20160 & 42 \\
Tr Prop+Priv/res & 10169,69 & 7849,75613 & 42 \\
\hline
\end{tabular}

\section{Correlations}

\begin{tabular}{|ll|r|r|}
\hline & & & Tr \\
& & Efic_DEA & Prop+Priv/res \\
\hline Pearson Correlation & Efic_DEA & 1,000 &, 062 \\
& Tr Prop+Priv/res &, 062 & 1,000 \\
\hline Sig. (1-tailed) & Efic_DEA &, &, 347 \\
& Tr Prop+Priv/res &, 347 &, \\
\hline N & Efic_DEA & 42 & 42 \\
& Tr Prop+Priv/res & 42 & 42 \\
\hline
\end{tabular}

ANOVA

\begin{tabular}{|ll|r|r|r|r|r|}
\hline \multicolumn{1}{|c|}{} & $\begin{array}{c}\text { Sum of } \\
\text { Model }\end{array}$ & Squares & df & Mean Square & F & Sig. \\
\hline 1 & Regression & 71,810 & 1 & 71,810 &, 156 &, $695^{\text {a }}$ \\
& Residual & 18358,008 & 40 & 458,950 & & \\
& Total & 18429,818 & 41 & & & \\
\hline
\end{tabular}

a. Predictors: (Constant), Tr Prop+Priv/res

b. Dependent Variable: Efic_DEA

Considerando-se um grau de confiança de 95\%, a análise de variância (Anova) aponta que a variável independente (valor das Receitas Próprias + Transferências Privadas por residente) não explica as variações da Eficiência DEA (variável dependente), conforme observado pelo teste de significância de $\mathrm{F}(>0,5)$, indicando que o coeficiente de determinação $\left(\mathrm{R}^{2}\right)$ pode ser igual a zero. Assim, o modelo de regressão linear analisado não é significativo sob o enfoque estatístico.

Os resultados obtidos sugerem que a quantidade ou a proporção de recursos originados de fontes próprias e privadas, perante o total das receitas obtidas, não explicam, objetivamente, a eficiência apresentada pelas ILPIs. Dessa maneira, a maior dependência por recursos próprios e privados não aponta para um maior nível de eficiência, sugerindo que os responsáveis pelas respectivas fontes de recursos podem não utilizar mecanismos de controle ou incentivos 
específicos para diferenciar o desempenho das organizações daquelas com maior dependência por recursos públicos.

\subsubsection{Receitas totais}

Complementando-se a discussão sobre possíveis relações entre os recursos recebidos e o nível de eficiência, a seguir são apresentadas as análises envolvendo o total das receitas com os valores de eficiência das ILPIs. Considerou-se a soma nominal dos recursos públicos e privados, assim como esse montante por residente.

\subsubsection{Valor nominal das receitas totais}

\section{Descriptive Statistics}

\begin{tabular}{|l|c|r|r|}
\hline & \multicolumn{1}{|c|}{ Mean } & Std. Deviation & \multicolumn{1}{|c|}{ N } \\
\hline Efic_DEA & 70,1485 & 21,20160 & 42 \\
Receita Total & 569808,9 & 507534,74946 & 42 \\
\hline
\end{tabular}

\section{Correlations}

\begin{tabular}{|ll|r|r|}
\hline & & Efic_DEA & Receita Total \\
\hline Pearson Correlation & Efic_DEA & 1,000 &, 018 \\
& Receita Total &, 018 & 1,000 \\
\hline Sig. (1-tailed) & Efic_DEA &, &, 454 \\
& Receita Total &, 454 &, \\
\hline $\mathrm{N}$ & Efic_DEA & 42 & 42 \\
& Receita Total & 42 & 42 \\
\hline
\end{tabular}

ANOVA $^{b}$

\begin{tabular}{|rl|r|r|r|r|r|}
\hline \multicolumn{1}{|c|}{} & $\begin{array}{c}\text { Sum of } \\
\text { Model }\end{array}$ & Squares & df & Mean Square & \multicolumn{1}{c|}{ F } & Sig. \\
\hline 1 & Regression & 6,246 & 1 & 6,246 &, 014 &, $908^{a}$ \\
& Residual & 18423,572 & 40 & 460,589 & & \\
& Total & 18429,818 & 41 & & & \\
\hline
\end{tabular}

a. Predictors: (Constant), Receita Total

b. Dependent Variable: Efic_DEA

Considerando-se um grau de confiança de 95\%, a análise de variância (Anova) aponta que a variável independente (valor nominal das Receitas Totais) não explica as variações da 
Eficiência DEA (variável dependente), conforme observado pelo teste de significância de $\mathrm{F}$ $(>0,5)$, indicando que o coeficiente de determinação $\left(\mathrm{R}^{2}\right)$ pode ser igual a zero. Assim, o modelo de regressão linear analisado não é significativo sob o enfoque estatístico.

\subsubsection{Receitas totais por residente}

\section{Descriptive Statistics}

\begin{tabular}{|l|c|r|r|}
\hline & \multicolumn{1}{|c|}{ Mean } & Std. Deviation & \multicolumn{1}{|c|}{ N } \\
\hline Efic_DEA & 70,1485 & 21,20160 & 42 \\
Rec Total/res & 12443,23 & 7956,23142 & 42 \\
\hline
\end{tabular}

\section{Correlations}

\begin{tabular}{|ll|r|r|}
\hline & & Efic_DEA & Rec Total/res \\
\hline Pearson Correlation & Efic_DEA & 1,000 &, 125 \\
& Rec Total/res &, 125 & 1,000 \\
\hline Sig. (1-tailed) & Efic_DEA &, &, 216 \\
& Rec Total/res &, 216 &, \\
\hline $\mathrm{N}$ & Efic_DEA & 42 & 42 \\
& Rec Total/res & 42 & 42 \\
\hline
\end{tabular}

ANOVA

\begin{tabular}{|rl|r|r|r|r|r|}
\hline \multicolumn{1}{|c|}{} & \multicolumn{1}{c|}{$\begin{array}{c}\text { Sum of } \\
\text { Model }\end{array}$} & Squares & $\mathrm{df}$ & Mean Square & $\mathrm{F}$ & Sig. \\
\hline 1 & Regression & 286,336 & 1 & 286,336 &, 631 &, $432^{\mathrm{a}}$ \\
& Residual & 18143,482 & 40 & 453,587 & & \\
& Total & 18429,818 & 41 & & & \\
\hline
\end{tabular}

a. Predictors: (Constant), Rec Total/res

b. Dependent Variable: Efic_DEA

Considerando-se um grau de confiança de 95\%, a análise de variância (Anova) aponta que a variável independente (valor das Receitas Totais por residente) não explica as variações da Eficiência DEA (variável dependente), conforme observado pelo teste de significância de $\mathrm{F}$ $(>0,5)$, indicando que o coeficiente de determinação $\left(\mathrm{R}^{2}\right)$ pode ser igual a zero. Assim, o modelo de regressão linear analisado não é significativo sob o enfoque estatístico. 
Os resultados obtidos apontaram que não se pode afirmar que é o montante nominal ou o valor recebido por residente que explicam a eficiência das ILPIs analisadas. Dessa maneira, sugere-se que não é o volume absoluto ou relativo de receitas que explicará, significativamente e sob a perspectiva estatística, o nível de eficiência das organizações asilares filantrópicas paulistas.

\subsubsection{Resultado financeiro}

Para se testar a hipótese $\mathrm{H} 2$, a qual pressupõe a existência de relação significativa entre o nível de eficiência e o resultado financeiro das ILPIs, foram analisadas as seguintes variáveis independentes no modelo de regressão linear: resultado financeiro nominal e resultado financeiro por residente.

\subsubsection{Valor nominal do resultado (receitas - despesas)}

\section{Descriptive Statistics}

\begin{tabular}{|l|c|r|r|}
\hline & \multicolumn{1}{|c|}{ Mean } & Std. Deviation & \multicolumn{1}{|c|}{$\mathrm{N}$} \\
\hline Efic_DEA & 70,1485 & 21,20160 & 42 \\
Rt-Dt nominal & $-21117,5$ & 264498,61768 & 42 \\
\hline
\end{tabular}

\section{Correlations}

\begin{tabular}{|ll|r|r|}
\hline & & Efic_DEA & Rt-Dt nominal \\
\hline Pearson Correlation & Efic_DEA & 1,000 &, 472 \\
& Rt-Dt nominal &, 472 & 1,000 \\
\hline Sig. (1-tailed) & Efic_DEA &, &, 001 \\
& Rt-Dt nominal &, 001 &, \\
\hline $\mathrm{N}$ & Efic_DEA & 42 & 42 \\
& Rt-Dt nominal & 42 & 42 \\
\hline
\end{tabular}


ANOVA

\begin{tabular}{|ll|c|r|r|r|r|}
\hline \multicolumn{1}{|l|}{} & & Sum of & & & & \\
\hline 1 & Squares & df & Mean Square & F & Sig. \\
\hline & Regression & 4111,085 & 1 & 4111,085 & 11,484 &, $002^{a}$ \\
& Residual & 14318,733 & 40 & 357,968 & & \\
& Total & 18429,818 & 41 & & & \\
\hline
\end{tabular}

a. Predictors: (Constant), Rt-Dt nominal

b. Dependent Variable: Efic_DEA

Considerando-se um grau de confiança de 95\%, a análise de variância (Anova) aponta que a variável independente (valor nominal das receitas totais - despesas totais) explica parcialmente as variações da Eficiência DEA (variável dependente), conforme observado pelo teste de significância de $\mathrm{F}(<0,5)$, assim, rejeita-se a hipótese de que o valor do coeficiente de determinação $\left(\mathrm{R}^{2}\right)$ seja igual a zero e aceita-se que o modelo de regressão linear é significativo.

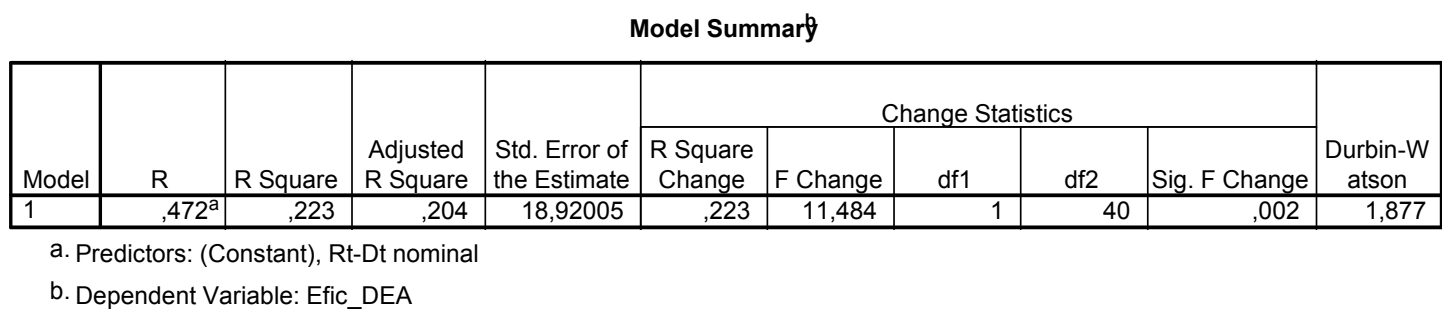

O coeficiente de determinação ajustado indica que a variável independente (valor nominal do resultado) explica 20,4\% da variação observada na eficiência calculada pela DEA.

\begin{tabular}{|c|c|c|c|c|c|c|c|c|c|c|c|c|c|}
\hline \multicolumn{14}{|c|}{ Coefficients } \\
\hline \multirow{2}{*}{\multicolumn{2}{|c|}{ Mode }} & \multicolumn{3}{|c|}{$\begin{array}{|cc|}\begin{array}{c}\text { Unstandardized } \\
\text { Coefficients }\end{array} & \begin{array}{l}\text { tandardized } \\
\text { Coefficients }\end{array} \\
\end{array}$} & \multirow[b]{2}{*}{$t$} & \multirow[b]{2}{*}{ Sig. } & \multicolumn{2}{|c|}{ o Confidence Interval fo } & \multicolumn{3}{|c|}{ Correlations } & \multicolumn{2}{|c|}{ Eollinearity Statistic } \\
\hline & & $\mathrm{B}$ & Std. Error & Beta & & & ower Bound & dpper Bounce & Ero-orde & el Partial & Part & Tolerance & VIF \\
\hline & (Constant) & 70,948 & 2,929 & & 24,223 &, 000 & 65,028 & 76,868 & & & & & \\
\hline & Rt-Dt nomif & $86 E-05$ & ,000 & ,472 & 3,389 & ,002 & ,000 & ,000 &, 472 & ,472 & ,472 & 1,000 & 1,000 \\
\hline
\end{tabular}

a.Dependent Variable: Efic_DEA 


\section{Collinearity Diagnostics}

\begin{tabular}{|c|c|c|c|c|c|}
\hline \multirow[b]{2}{*}{ Model } & \multirow[b]{2}{*}{ Dimension } & \multirow[b]{2}{*}{ Eigenvalue } & \multirow{2}{*}{$\begin{array}{c}\text { Condition } \\
\text { Index }\end{array}$} & \multicolumn{2}{|c|}{ Variance Proportions } \\
\hline & & & & (Constant) & Rt-Dt nominal \\
\hline 1 & 1 & 1,081 & 1,000 & ,46 & $\overline{, 46}$ \\
\hline & 2 & ,919 & 1,084 & ,54 & ,54 \\
\hline
\end{tabular}

a. Dependent Variable: Efic_DEA

\section{Residuals Statistics ${ }^{\mathrm{a}}$}

\begin{tabular}{|l|r|r|r|r|r|}
\hline & \multicolumn{1}{|c|}{ Minimum } & Maximum & \multicolumn{1}{|c|}{ Mean } & Std. Deviation & \multicolumn{1}{c|}{ N } \\
\hline Predicted Value & 39,3746 & 96,9476 & 70,1485 & 10,01351 & 42 \\
Residual & $-35,9397$ & 34,4315 &, 0000 & 18,68789 & 42 \\
Std. Predicted Value & $-3,073$ & 2,676 &, 000 & 1,000 & 42 \\
Std. Residual & $-1,900$ & 1,820 &, 000 &, 988 & 42 \\
\hline
\end{tabular}

a. Dependent Variable: Efic_DEA

A seguir, testa-se o pressuposto da normalidade dos resíduos, em que a hipótese nula (H0) é a de que a distribuição da série testada é normal.

One-Sample Kolmogorov-Smirnov Test

\begin{tabular}{|ll|r|}
\hline & & \multicolumn{1}{|c|}{$\begin{array}{c}\text { Standardized } \\
\text { Residual }\end{array}$} \\
\hline $\mathrm{N}$ & & 42 \\
Normal Parameters ${ }^{\mathrm{a} b} \mathrm{~b}$ & Mean &, 0000000 \\
& Std. Deviation &, 98772961 \\
Most Extreme & Absolute &, 125 \\
Differences & Positive &, 118 \\
& Negative &,- 125 \\
Kolmogorov-Smirnov Z & &, 809 \\
Asymp. Sig. (2-tailed) & &, 529 \\
\hline
\end{tabular}

a. Test distribution is Normal.

b. Calculated from data.

Conforme o teste de Kolmogorov-Smirnov, aceita-se H0, ou seja, a distribuição testada é normal.

Para o teste de Pesaran-Pesaran, a seguir, a hipótese nula (H0) é de que os resíduos são homoscedáticos. 
ANOVA

\begin{tabular}{|rl|r|r|r|r|r|}
\hline \multicolumn{1}{|l|}{} & \multicolumn{1}{|c|}{$\begin{array}{c}\text { Sum of } \\
\text { Sodel }\end{array}$} & Squares & df & Mean Square & \multicolumn{1}{c|}{ F } & \multicolumn{1}{c|}{ Sig. } \\
\hline 1 & Regression &, 008 & 1 &, 008 &, 008 &, $927^{\text {a }}$ \\
& Residual & 37,192 & 40 &, 930 & & \\
& Total & 37,200 & 41 & & & \\
\hline
\end{tabular}

a. Predictors: (Constant), ZPR_2

b. Dependent Variable: ZRE_2

A análise de variância dos resíduos padronizados aponta para a aceitação de H0, logo os resíduos analisados mantêm uma variação constante.

Assim, os resultados apresentados na análise indicam que os pressupostos do modelo de regressão linear simples foram atendidos.

\subsubsection{Resultado (receitas - despesas) por residente}

Descriptive Statistics

\begin{tabular}{|l|r|r|r|}
\hline & \multicolumn{1}{|c|}{ Mean } & \multicolumn{1}{|c|}{ Std. Deviation } & \multicolumn{1}{|c|}{ N } \\
\hline Efic_DEA & 70,1485 & 21,20160 & 42 \\
Rt-Dt res & $-441,2951$ & 5475,73985 & 42 \\
\hline
\end{tabular}

Correlations

\begin{tabular}{|ll|r|r|}
\hline & & Efic_DEA & Rt-Dt res \\
\hline Pearson Correlation & Efic_DEA & 1,000 &, 501 \\
& Rt-Dt res &, 501 & 1,000 \\
\hline Sig. (1-tailed) & Efic_DEA &, &, 000 \\
& Rt-Dt res &, 000 &, \\
\hline $\mathrm{N}$ & Efic_DEA & 42 & 42 \\
& Rt-Dt res & 42 & 42 \\
\hline
\end{tabular}


ANOVA

\begin{tabular}{|ll|r|r|r|r|r|}
\hline \multicolumn{1}{|c|}{} & \multicolumn{1}{|c|}{ Sum of } & & & & \\
\hline 1 & Squares & $\mathrm{df}$ & Mean Square & $\mathrm{F}$ & Sig. \\
\hline & Regression & 4627,855 & 1 & 4627,855 & 13,412 &, $001^{\text {a }}$ \\
& Residual & 13801,964 & 40 & 345,049 & & \\
& Total & 18429,818 & 41 & & & \\
\hline
\end{tabular}

a. Predictors: (Constant), Rt-Dt res

b. Dependent Variable: Efic_DEA

Considerando-se um grau de confiança de 95\%, a análise de variância (Anova) aponta que a variável independente (Receitas Totais - Despesas Totais, por residente) explica parcialmente as variações da Eficiência DEA (variável dependente), conforme observado pelo teste de significância de $\mathrm{F}(<0,5)$, assim, rejeita-se a hipótese de que o valor do coeficiente de determinação $\left(\mathrm{R}^{2}\right)$ seja igual a zero e aceita-se que o modelo de regressão linear é estatisticamente significativo.

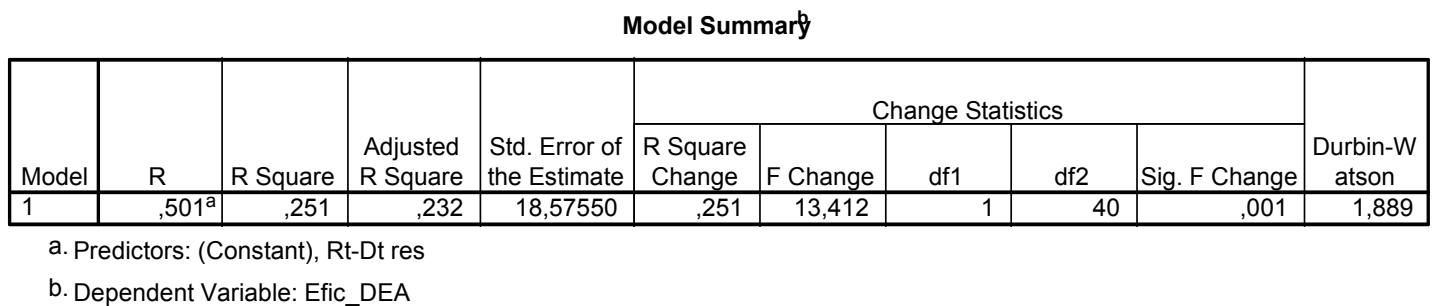

O coeficiente de determinação ajustado indica que a variável independente (valor do resultado por residente) explica $23,2 \%$ da variação observada na Eficiência DEA. O poder de explicação do modelo de regressão, utilizando-se como variável independente o valor do resultado por residente, é superior do que quando se utiliza como variável independente o valor nominal do resultado.

\begin{tabular}{|c|c|c|c|c|c|c|c|c|c|c|c|c|c|}
\hline & & & & & & $\mathrm{Coe}$ & efficients & & & & & & \\
\hline \multirow[b]{2}{*}{ Model } & & \multicolumn{2}{|c|}{$\begin{array}{c}\text { Unstandardized } \\
\text { Coefficients }\end{array}$} & \multirow{2}{*}{\begin{tabular}{|c|}
$\begin{array}{c}\text { Standardized } \\
\text { Coefficients }\end{array}$ \\
Beta \\
\end{tabular}} & \multirow[b]{2}{*}{$\mathrm{t}$} & \multirow[b]{2}{*}{ Sig. } & \multicolumn{2}{|c|}{$\%$ Confidence Interval for } & \multicolumn{3}{|c|}{ Correlations } & \multicolumn{2}{|c|}{ Sollinearity Statistics } \\
\hline & & $B$ & Std. Error & & & & -ower Bound & Upper Bound & Zero-order & Partial & Part & Tolerance & VIF \\
\hline & (Constan & 71,005 & 2,876 & & 24,691 & ,000 & 65,193 & 76,817 & & & & & \\
\hline & Rt-Dt res & $940 \mathrm{E}-03$ & ,001 &, 501 & 3,662 & ,001 &, 001 & ,003 &, 501 &, 501 & ,501 & 1,000 & 1,000 \\
\hline
\end{tabular}

a.Dependent Variable: Efic_DEA 
Collinearity Diagnostics

\begin{tabular}{|ll|r|r|r|r|}
\hline & & & \multicolumn{2}{|c|}{} \\
\cline { 5 - 6 } Model & Dimension & Eigenvalue & Condition & \multicolumn{2}{|c|}{ Variance Proportions } \\
\cline { 5 - 6 } & 1 & 1,081 & 1,000 &, 46 &, 46 \\
& 1 &, 919 & 1,085 &, 54 &, 54 \\
\hline
\end{tabular}

a. Dependent Variable: Efic_DEA

Residuals Statistics

\begin{tabular}{|l|r|r|r|r|r|}
\hline & \multicolumn{1}{|c|}{ Minimum } & Maximum & \multicolumn{1}{c|}{ Mean } & Std. Deviation & $\mathrm{N}$ \\
\hline Predicted Value & 43,6050 & 94,1860 & 70,1485 & 10,62424 & 42 \\
Residual & $-33,2657$ & 28,3995 &, 0000 & 18,34757 & 42 \\
Std. Predicted Value & $-2,498$ & 2,263 &, 000 & 1,000 & 42 \\
Std. Residual & $-1,791$ & 1,529 &, 000 &, 988 & 42 \\
\hline
\end{tabular}

a. Dependent Variable: Efic_DEA

A seguir, testa-se o pressuposto da normalidade dos resíduos, em que a hipótese nula (H0) é a de que a distribuição da série testada é normal.

One-Sample Kolmogorov-Smirnov Test

\begin{tabular}{|ll|r|}
\hline & & \multicolumn{1}{|c|}{$\begin{array}{c}\text { Standardized } \\
\text { Residual }\end{array}$} \\
\hline N & 42 \\
Normal Parametersa,b & Mean &, 0000000 \\
Most Extreme & Std. Deviation &, 98772961 \\
Differences & Absolute &, 158 \\
& Positive &, 103 \\
Kolmogorov-Smirnov Z & Negative &,- 158 \\
Asymp. Sig. (2-tailed) & & 1,026 \\
\end{tabular}

a. Test distribution is Normal.

b. Calculated from data.

Conforme o teste de Kolmogorov-Smirnov, aceita-se H0, ou seja, a distribuição testada é normal.

Para o teste de Pesaran-Pesaran, a seguir, a hipótese nula (H0) é de que os resíduos são homoscedáticos. 
ANOVA

\begin{tabular}{|rl|r|r|r|r|r|}
\hline \multicolumn{1}{|c|}{} & \multicolumn{1}{|c|}{$\begin{array}{c}\text { Sum of } \\
\text { Sodel }\end{array}$} & Squares & $\mathrm{df}$ & Mean Square & $\mathrm{F}$ & Sig. \\
\hline 1 & Regression &, 913 & 1 &, 913 & 1,083 &, $304^{\mathrm{a}}$ \\
& Residual & 33,720 & 40 &, 843 & & \\
& Total & 34,632 & 41 & & & \\
\hline
\end{tabular}

a. Predictors: (Constant), zpr_2 Rt-Dt r

b. Dependent Variable: zre_2 Rt-Dt r

A análise de variância dos resíduos padronizados aponta para a aceitação de H0, logo os resíduos analisados mantêm uma variação constante.

Assim, os resultados apresentados na análise indicam que os pressupostos do modelo de regressão linear simples foram atendidos.

Considerando-se que os valores nominais e relativos dos resultados financeiros apresentaram uma relação significativa e positiva com o nível de eficiência das ILPIs da amostra, aceita-se uma das hipóteses orientadora deste trabalho $(\mathrm{H} 2)$. As implicações dessa constatação refletem-se nos campos conceitual e prático.

O superávit e o déficit contábil de organizações sem fins lucrativos não evidenciam, a priori, se os objetivos sociais foram atingidos ou se a missão da entidade foi cumprida. Entretanto, ao se estabelecer uma relação estatisticamente significativa e positiva entre o resultado financeiro e a eficiência (a qual, neste trabalho, vincula-se diretamente a dados quantitativos, mas indiretamente a aspectos sociais e qualitativos), deve-se ponderar sobre a pertinência de resultados superavitários, fundamentais para a sobrevivência da organização e para novos investimentos. Ao contrário do que possa sugerir a expressão "sem fins lucrativos", a intenção de continuidade operacional no longo prazo exige resultados financeiros superavitários capazes de financiar e assegurar a longevidade das ILPIs e, para o grupo filantrópico analisado, a eficiência também se aproxima do desempenho financeiro positivo. 


\subsubsection{Grau de disclosure}

A análise de regressão linear, a seguir, vincula-se ao teste da hipótese $\mathrm{H} 3$, objetivando-se verificar se o nível de eficiência das ILPIs possui relação significativa com o grau de disclosure.

\subsubsection{Disclosure}

Descriptive Statistics

\begin{tabular}{|l|l|r|r|}
\hline & Mean & Std. Deviation & \multicolumn{1}{|c|}{$\mathrm{N}$} \\
\hline Efic_DEA & 70,1485 & 21,20160 & 42 \\
Discl & 36,6857 & 9,69163 & 42 \\
\hline
\end{tabular}

Correlations

\begin{tabular}{|ll|r|r|}
\hline & & Efic_DEA & \multicolumn{1}{|c|}{ Discl } \\
\hline Pearson Correlation & Efic_DEA & 1,000 &, 834 \\
& Discl &, 834 & 1,000 \\
\hline Sig. (1-tailed) & Efic_DEA &, &, 000 \\
& Discl &, 000 &, \\
\hline $\mathrm{N}$ & Efic_DEA & 42 & 42 \\
& Discl & 42 & 42 \\
\hline
\end{tabular}

ANOVA

\begin{tabular}{|ll|r|r|r|r|r|}
\hline \multicolumn{1}{|c|}{} & \multicolumn{1}{c|}{$\begin{array}{c}\text { Sum of } \\
\text { Model }\end{array}$} & Squares & df & Mean Square & \multicolumn{1}{c|}{ F } & Sig. \\
\hline 1 & Regression & 12830,552 & 1 & 12830,552 & 91,659 &, $000^{\text {a }}$ \\
& Residual & 5599,266 & 40 & 139,982 & & \\
& Total & 18429,818 & 41 & & & \\
\hline
\end{tabular}

a. Predictors: (Constant), Discl

b. Dependent Variable: Efic_DEA

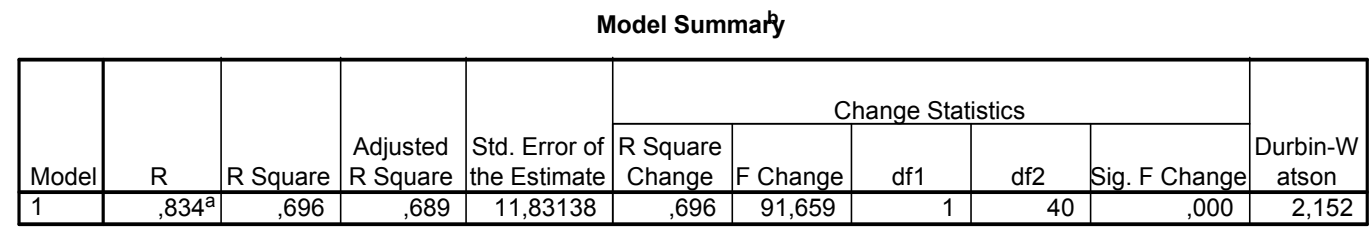

a. Predictors: (Constant), Discl

b. Dependent Variable: Efic_DEA 
O coeficiente de determinação ajustado indica que a variável independente (grau de disclosure) explica 68,9\% da variação observada na Eficiência DEA.

\begin{tabular}{|c|c|c|c|c|c|c|c|c|c|c|c|c|c|}
\hline \multicolumn{14}{|c|}{ Coefficients } \\
\hline \multirow[b]{2}{*}{ Mode } & & \multicolumn{2}{|c|}{$\begin{array}{c}\text { Unstandardized } \\
\text { Coefficients }\end{array}$} & \multirow{2}{*}{\begin{tabular}{|c|}
$\begin{array}{l}\text { Standardized } \\
\text { Coefficients }\end{array}$ \\
Beta \\
\end{tabular}} & \multirow[b]{2}{*}{$\mathrm{t}$} & \multirow[b]{2}{*}{ Sig. } & \multicolumn{2}{|c|}{ \% Confidence Interval fd } & \multicolumn{3}{|c|}{ Correlations } & \multicolumn{2}{|c|}{ ollinearity Statistic } \\
\hline & & $B$ & Std. Error & & & & ower Bounc & pper Bound & Zero-order & Partial & Part & Tolerance & VIF \\
\hline 1 & (Constan & 3,186 & 7,229 & & ,441 & ,662 & $-11,424$ & 17,796 & & & & & \\
\hline & Discl & 1,825 & ,191 & 834 & 9,574 &, 000 & 1,440 & 2,211 & ,834 & 834 & ,834 & 1,000 & 1,000 \\
\hline
\end{tabular}

\section{Collinearity Diagnostics}

\begin{tabular}{|c|c|c|c|c|c|}
\hline \multirow[b]{2}{*}{ Model } & \multirow[b]{2}{*}{ Dimension } & \multirow[b]{2}{*}{ Eigenvalue } & \multirow{2}{*}{$\begin{array}{l}\text { Condition } \\
\text { Index }\end{array}$} & \multicolumn{2}{|c|}{ Variance Proportions } \\
\hline & & & & (Constant) & Discl \\
\hline \multirow[t]{2}{*}{1} & 1 & 1,968 & 1,000 &, 02 & ,02 \\
\hline & 2 & 3,242E-02 & 7,791 & ,98 & ,98 \\
\hline
\end{tabular}

a. Dependent Variable: Efic_DEA

\section{Residuals Statistics}

\begin{tabular}{|l|r|r|r|r|r|}
\hline & \multicolumn{1}{|c|}{ Minimum } & \multicolumn{1}{|c|}{ Maximum } & \multicolumn{1}{c|}{ Mean } & Std. Deviation & \multicolumn{1}{c|}{$\mathrm{N}$} \\
\hline Predicted Value & 40,9698 & 110,1486 & 70,1485 & 17,69012 & 42 \\
Residual & $-30,5411$ & 30,2485 &, 0000 & 11,68621 & 42 \\
Std. Predicted Value & $-1,649$ & 2,261 &, 000 & 1,000 & 42 \\
Std. Residual & $-2,581$ & 2,557 &, 000 &, 988 & 42 \\
\hline
\end{tabular}

a. Dependent Variable: Efic_DEA

A seguir, testa-se o pressuposto da normalidade dos resíduos, em que a hipótese nula (H0) é a de que a distribuição da série testada é normal. 


\section{One-Sample Kolmogorov-Smirnov Test}

\begin{tabular}{|ll|r|}
\hline & & \multicolumn{1}{|c|}{$\begin{array}{c}\text { Standardized } \\
\text { Residual }\end{array}$} \\
\hline $\mathrm{N}$ & & 42 \\
Normal Parameters ${ }^{\mathrm{a}, \mathrm{b}}$ & Mean &, 0000000 \\
& Std. Deviation &, 98772961 \\
Most Extreme & Absolute &, 144 \\
Differences & Positive &, 082 \\
& Negative &,- 144 \\
Kolmogorov-Smirnov Z & &, 936 \\
Asymp. Sig. (2-tailed) & &, 345 \\
\hline
\end{tabular}

a. Test distribution is Normal.

b. Calculated from data.

Conforme o teste de Kolmogorov-Smirnov, aceita-se H0, ou seja, a distribuição testada é normal.

Para o teste de Pesaran-Pesaran, a seguir, a hipótese nula (H0) é de que os resíduos são homoscedáticos.

ANOVA

\begin{tabular}{|ll|r|r|r|r|r|}
\hline Model & & $\begin{array}{c}\text { Sum of } \\
\text { Squares }\end{array}$ & df & Mean Square & \multicolumn{1}{c|}{$\mathrm{F}$} & \multicolumn{1}{c|}{ Sig. } \\
\hline 1 & Regression &, 039 & 1 &, 039 &, 013 &, $910^{\mathrm{a}}$ \\
& Residual & 121,585 & 40 & 3,040 & & \\
& Total & 121,625 & 41 & & & \\
\hline
\end{tabular}

a. Predictors: (Constant), zpr_2 Discl

b. Dependent Variable: zre_2 Discl

A análise de variância dos resíduos padronizados aponta para a aceitação de H0, logo os resíduos analisados mantêm uma variação constante. Assim, os resultados apresentados na análise indicam que os pressupostos do modelo de regressão linear simples foram atendidos.

Apesar do baixo grau de disclosure das ILPIs, conforme já apresentado na seção 4.1.9, tal variável mostrou-se significativamente relacionada com a eficiência das entidades. Esse fato sugere que as organizações que mais evidenciam suas informações são aquelas que demonstram possuir uma melhor relação de consumo de seus insumos com os indicadores de desempenho da Anvisa. Dessa maneira, a terceira hipótese desta pesquisa $(\mathrm{H} 3)$ pode ser aceita. 


\section{CONCLUSÃO}

O objetivo geral deste trabalho foi atingido ao se classificar as organizações pesquisadas conforme os seus respectivos níveis de eficiência produtiva, utilizando-se um modelo quantitativo, além de se investigar a existência (ou ausência) de relações estatisticamente significativas entre a eficiência e o grau de dependência por recursos públicos e privados, os seus resultados financeiros e, também, o nível de disclosure.

$\mathrm{Na}$ amostra, formada por 42 ILPIs, uma organização (DMU ${ }^{\circ}{ }^{12}$ ) foi classificada como a mais eficiente, seguindo-se o critério do cálculo composto entre as fronteiras padrão e invertida, enquanto que as DMUs $\mathrm{n}^{\circ} \mathrm{s} 1,8,13,25,31,34,38$ e 39 foram aquelas que apresentaram o grau de eficiência relativa mais baixo (a DMU $\mathrm{n}^{\circ} 8$ apresentou eficiência acima da média pelo cálculo composto, mas foi classificada entre as mais ineficientes pelo cálculo da fronteira padrão).

Os valores projetados como alvos às DMUs ineficientes, conforme apresentado no Apêndice 3 , sugerem que os gestores dessas organizações deveriam rever a atual relação entre insumos e produtos perante os indicadores de desempenho estabelecidos pela Anvisa e apresentados no período em estudo.

A utilização excessiva do input Trabalho (horas totais trabalhadas por funcionários e por voluntários) pode indicar que há má utilização desse fator sem reflexos positivos no desempenho, assim como identificado nos inputs relacionados ao Capital (Ativo Permanente e Despesas Totais), os quais podem sugerir um dimensionamento acima do necessário e gastos em excesso. Ao se analisar os insumos em certo nível de desempenho medidos pelos indicadores de saúde da Anvisa, não se espera que as ILPIs apenas reduzam a utilização dos fatores, mas que promovam maior eficiência aumentando os resultados desses mesmos indicadores de saúde.

Contrariamente a uma das hipóteses direcionadoras desta pesquisa (H1), verificou-se que inexiste relação significativa entre o nível de dependência por transferências públicas com nível de eficiência produtiva das entidades analisadas. Essa situação não permite afirmar, portanto, que quanto maior o grau de dependência por recursos públicos, menor é o nível de 
eficiência produtiva das ILPIs do Estado de São Paulo, estimulando a reflexão sobre a validade da aplicação conceitual da Soft Budget Constraint nas organizações filantrópicas asilares. Também não se pode afirmar que as ILPIs mais dependentes por recursos públicos recebem incentivos do Estado para que apresentem um desempenho superior em comparação às demais ILPIs.

Os resultados das análises de regressão linear, que relacionaram o grau de eficiência das ILPIs com os seus respectivos resultados financeiros (nominal e por residente), permitiram aceitar a hipótese H2, a qual supunha que, quanto maior o resultado (receitas - despesas), maior seria o nível de eficiência produtiva das instituições filantrópicas de longa permanência para idosos do Estado de São Paulo. Esse fato faz com que o resultado contábil obtido pelas organizações filantrópicas pesquisadas constitua-se numa variável relevante para a respectiva avaliação de desempenho, contrapondo-se a possíveis argumentos de que as demonstrações contábeis de entidades sem fins lucrativos não estariam relacionadas ao desempenho social de suas atividades. Considerando-se que, neste estudo, o montante das receitas (nominais e por residente) não apresentou relação significativa com a eficiência produtiva das ILPIs, mas os resultados financeiros apresentaram, pode-se relacionar a eficiência com a gestão dos recursos.

Com relação ao teste da hipótese sobre a relação entre eficiência e nível de disclosure $(\mathrm{H} 3)$, confirmou-se a expectativa de que há relação significativa entre essas variáveis, permitindo afirmar (sem o estabelecimento de relação causal) que, quanto maior o nível de disclosure, maior é o nível de eficiência produtiva das ILPIs. Esse resultado sugere que a adoção de instrumentos e práticas de evidenciação pode não estar associada ao comportamento isomórfico previsto pela Teoria Institucional. A existência de um possível isomorfismo implicaria em correlações fracas ou inexistentes entre os níveis de disclosure e de eficiência produtiva.

O critério utilizado nesta pesquisa para se mensurar o grau de disclosure das ILPIs considerou a disponibilização pública de itens obrigatórios e voluntários. Destacou-se, entretanto, o fato de que nem mesmo os itens de divulgação obrigatória são disponibilizados, integralmente, ao público em geral pela maioria das ILPIs. Outro fato a se destacar é que, dentre as organizações que escolheram não colaborar com esta pesquisa, algumas delas alegaram que os dados financeiros eram sigilosos, contrariando a legislação vigente que obriga a respectiva 
divulgação financeira das entidades filantrópicas. Assumindo-se que a base para a avaliação de desempenho é a accountability e, ainda, sem a ocorrência do devido monitoramento social e de pressões para a prestação de contas por parte de seus stakeholders, a assimetria informacional pode comprometer a credibilidade dessas entidades perante a sociedade de forma geral.

A opacidade de algumas organizações fere a Resolução 283/2005 da Anvisa, a qual estabelece que deve ser fácil o acesso aos dados necessários para a fiscalização e controle social, além do artigo 54 da Lei 10.741/2003, o qual exige a publicidade das prestações de contas dos recursos públicos e privados recebidos pelas ILPIs.

Uma das propostas deste trabalho foi oferecer elementos conceituais e dados empíricos para a discussão sobre a alocação eficiente de recursos escassos da sociedade, que é um dos problemas essenciais na economia. Nesse sentido, os órgãos governamentais e os doadores de recursos em geral poderiam incentivar o aumento da eficiência das ILPIs ineficientes estabelecendo metas e liberando recursos mediante o comprometimento e o monitoramento do aumento da respectiva eficiência produtiva, além de exigirem prestações de contas com um nível mínimo de transparência e credibilidade das informações. 


\section{REFERÊNCIAS}

ABBOTTA, M.; DOUCOUliAgOS, C. The efficiency of Australian universities: a data envelopment analysis. Economics of Education Review, v. 22, n. 1, p. 89-97, Feb. 2003.

AGÊNCIA NACIONAL DE VIGILÂNCIA SANITÁRIA - ANVISA. Resolução RDC no 283, de 26 de setembro de 2005. Disponível em: $<$ http://elegis.anvisa.gov.br/leisref/public/showAct.php?id=17972\&word=>. Acesso em: 02/06/2008.

AMARAL, Deivison G. Confederação católica do trabalho: práticas discursivas e orientação católica para o trabalho em Belo Horizonte (1919-1930). Belo Horizonte, 2007. Dissertação (Mestrado em Ciências Sociais) - Programa de pós-graduação em Ciências Sociais, Pontifícia Universidade Católica de Minas Gerais.

ANDERSON, J. C.; FRANKLE, A.W. Voluntary social reporting: an iso-beta portfolio analysis. The Accounting Review, v. 55, n. 3, p. 467-479, Jul. 1980.

ANDION, Carolina; SERVA, Mauricio. Por uma visão positiva da sociedade civil: uma análise histórica da sociedade civil organizada no Brasil. Revista Venezolana de Economía Social, año 4, n. 7, Dic. 2004.

ANGULO MEZA, Lídia. Data envelopment analysis na determinação da eficiência dos Programas de Pós-Graduação da COPPE/UFRJ. Rio de Janeiro, 1998. Dissertação (Mestrado em Engenharia de Produção) - COPPE/UFRJ, Universidade Federal do Rio de Janeiro.

ARAÚJO, Osório C. Contabilidade para organizações do terceiro setor. São Paulo: Atlas, 2005.

ARAÚJO, Tereza C. N.; ALVES, Maria Isabel C. Perfil da população idosa no Brasil. Textos sobre envelhecimento, Rio de Janeiro, UnATI/UERJ, n. 3, p.7-19, 1. sem. 2000.

ATKINSON, Anthony A. et al. Contabilidade gerencial. São Paulo: Atlas, 2000.

BACHELARD, Gaston. A formação do espírito científico. Rio de Janeiro: Contraponto, 1996.

BANKER, R. D.; CHARNES, A.; COOPER, W. W. Some models for estimating technical and scale inefficiencies in data envelopment analysis. Management Science, v. 30, n. 9, p. 1078-1092, 1984.

BARBOSA, Maria N. L. Incentivos fiscais: uma abordagem ético-jurídica. Revista Integração, São Paulo, Fundação Getúlio Vargas, n. 4, jul. 2001. 
BASTO, Luís E. et al. Organizações públicas brasileiras: a busca da eficiência, da eficácia ou da efetividade? Revista de Administração Pública. Rio de Janeiro: FGV, v. 4, n. 27, p. 1426, out./dez. 1993.

BEHN, Bruce K. et al. Voluntary disclosure in nonprofit organizations: an exploratory study. Working Paper. Social Science Research Network. Feb. 2007. Disponível em: $<$ http://ssrn.com/abstract=727363>. Acesso em: 05/09/2008.

BELLONI, José A. Uma metodologia de avaliação da eficiência produtiva de universidades federais brasileiras. Florianópolis, 2000. Tese (Doutorado em Engenharia de Produção) - Departamento de Engenharia de Produção e Sistemas, Universidade Federal de Santa Catarina.

BERMAN, Evan M. Performance and productivity in public and nonprofit organizations. New York: M. E. Sharpe, 2006.

BHOJRAJ, S. et al. Voluntary disclosure in a multi-audience setting: an empirical analysis. The Accounting Review, v. 79, n. 4, p. 921-947, 2004.

BIO, Sérgio R. Sistemas de informações: um enfoque gerencial. São Paulo: Atlas, 1996.

BOARD, John et al. Transparency and fragmentation: financial market regulation in a dynamic environment. Houndmills: Palgrave Macmillan, 2002.

BOTOSAN, C. A. Disclosure level and the cost of equity capital. The Accounting Review, v. 72, n. 3, p. 323-349, 1997.

BRASIL. Decreto $n^{\circ} 2.536$, de 6 de abril de 1998. Dispõe sobre a concessão do certificado de entidade de fins filantrópicos. Diário Oficial da União, Brasília, 1998.

. Decreto $\mathrm{n}^{\mathrm{o}} 3.504$, de 13 junho de 2000. Dispõe sobre a concessão do certificado de entidade de fins fílantrópicos. Diário Oficial da União, Brasília, 2000.

. Lei $n^{\circ}$ 8.742, de 7 de dezembro de 1993. Lei da organização da assistência social. Diário Oficial da União, Brasília, 1993.

. Lei $\mathrm{n}^{0}$ 9.608, de 18 de fevereiro de 1998. Dispõe sobre o serviço voluntário. Diário Oficial da União, Brasília, 1998.

. Lei $\mathrm{n}^{\mathrm{0}} 10.098$, de 19 de dezembro de 2000. Normas gerais e critérios básicos para a promoção da acessibilidade das pessoas portadoras de deficiência ou com mobilidade reduzida. Diário Oficial da União, Brasília, 2000. 
BRASIL. Lei $\mathrm{n}^{\mathrm{o}} 10.741$, de $1^{\circ}$ de outubro de 2003 - Lei Especial - Estatuto do idoso. Diário Oficial da União, Brasília, 2003.

. Medida Provisória $\mathrm{n}^{\mathrm{o}}$ 446, de 10 de novembro de 2008. Dispõe sobre a certificação das entidades beneficentes de assistência social. Diário Oficial da União, Brasília, 2008.

BRESSER PEREIRA, Luiz Carlos. A reforma do Estado nos anos 90: lógica e mecanismos de controle. Cadernos Mare da Reforma do Estado, Brasília, n. 1, 1997.

. Reflexões sobre a reforma gerencial brasileira de 1995. Revista do Serviço Público, Brasília, v. 4, n. 50, 2000.

Do Estado patrimonial ao gerencial. In: PINHEIRO, W. et al. (Orgs.). Brasil: um século de transformações. São Paulo: Cia. Das Letras, 2001.

BRUYNE, Paul de et al. Dinâmica da pesquisa em ciências sociais: os pólos da prática metodológica. 5. ed. Rio de Janeiro: Francisco Alves, 1991.

BUSHMAN, Robert M. et al. What determines corporate transparency? Journal of Accounting Research, v. 42, n. 2, May. 2004.

; SMITH, Abbie J. Transparency, financial accounting information and corporate governance. FRBNY Economic Policy Review, p. 65-87, Apr. 2003.

CALLEN, Jeffrey L. et al. Board composition, committees and organizational efficiency: the case of nonprofits. Nonprofit and Voluntary Sector Quarterly, v. 32, n. 4, p. 493-520, 2003.

CAMARANO, Ana A. (Org.). Características das instituições de longa permanência para idosos: Região Norte. Rio de Janeiro: IPEA, 2006.

- Características das instituições de longa permanência para idosos: Região Centro-Oeste. Rio de Janeiro: IPEA, 2008a.

Características das instituições de longa permanência para idosos: Região Sul. Rio de Janeiro: IPEA, 2008 b.

CANADA REVENUE AGENCY - CRA. Fundraising guidelines: ONN's briefing note to the field. Ottawa: NonProfit Network, 2008.

CANUTO, Otaviano. A crise asiática e seus desdobramentos. Revista Econômica da Universidade Federal Fluminense, Rio de Janeiro, v. 2. n. 4. p. 25-60, Dez. 2000. 
CASSELL, Catherine; SYMON, Gillian. Qualitative methods in organizational research: a practical guide. London: Sage, 1994. 253p.

CENTRE FOR VOLUNTARY SECTOR RESEARCH AND DEVELOPMENT - CVSRD. Policy internships and fellowships. Ottawa: CVSRD and the Centre for Public Sector Studies, 2006.

CHARNES, A; COOPER, W.; RHODES, E. Measuring the efficiency of decision making units. European Journal of Operational Research, v. 2, n. 6, p. 429-444, 1978.

COELLI, Timothy J. et al. An introduction to efficiency and productivity analysis. Boston: Kluwer Academic Publishers, 1998.

CONSELHO FEDERAL DE CONTABILIDADE - CFC. Norma Brasileira de Contabilidade NBC T 6 - Da divulgação das demonstrações contábeis. Diário Oficial da União. Brasília, 1992.

. Norma Brasileira de Contabilidade NBC T 10.19 - Entidades sem finalidades de lucro. Diário Oficial da União. Brasília, 2000.

. Norma Brasileira de Contabilidade NBC T 19.4. Incentivos fiscais, subvenções, contribuições, auxílios e doações governamentais. Diário Oficial da União. Brasília, 2005.

CONSELHO NACIONAL DE ASSISTÊNCIA SOCIAL - CNAS. Resolução CNAS no 66 de 16 de abril de 2003. Disponível em: <http://www.adcontre.com.br/legislacaofilantropia.htm>. Acesso em: 06/2007.

- Resolução CNAS $\mathbf{n}^{0} \mathbf{1 7 7}$ de 10 de agosto de 2000. Disponível em: $\overline{<h t t p: / / w w w . a d c o n t r e . c o m . b r / l e g i s l a c a o f i l a n t r o p i a . h t m>. ~ A c e s s o ~ e m: ~ 15 / 06 / 2007 . ~}$

COOPER, William W et al. Data envelopment analysis: a comprehensive text with models, applications, references and DEA solver software. 2 ed. New York: Springer. 2007.

CORRAR, Luiz J. et al. Regressões. In: CORRAR, Luiz J.; THEÓPHILO, Renato (Org.). Pesquisa operacional para decisão em contabilidade e administração. São Paulo: Atlas, 2003.

CUNHA, Bruno T. et al. Implementação computacional de seleção de variáveis em DEA: um estudo de caso em avaliação educacional. In: XIII CLAIO Congreso LatinoIberoamericano de Investigación Operativa, Montevideo, 2006.

CUTT, James; MURRAY, Vic. Accountability and effectiveness evaluation in nonprofit organizations. New York: Routledge, 2000. 
DEMO, Pedro. Introdução à metodologia da ciência. 2. ed. São Paulo: Atlas, 1987.

DESAI, Mihir A.; YETMAN, Robert J. Constraining managers without owners: governance of the not-for-profit enterprise. Sept. 2006. Disponível em: $<\mathrm{http}: / /$ ssrn.com/abstract $=661301>$. Acesso em: 02/2008.

DIAS, Everardo. História das lutas sociais no Brasil. 2. ed. São Paulo: Alfa-Ômega, 1977.

DIEHL, Astor A.; TATIM, Denise C. Pesquisa em ciências sociais aplicadas: métodos e técnicas. São Paulo: Prentice Hall, 2004.

DIMAGGIO, Paul J.; POWELL, Walter. W. The iron cage revisited: institutional isomorphism and collective rationality in organizational fields. American Sociological Review, v. 48, p. 147-160, 1983.

. The new institutionalism in organizational analysis. Chicago: University of Chicago Press, 1991.

DRUCKER, Peter F. Administração de organizações sem fins lucrativos: princípios e práticas. São Paulo: Pioneira, 1994.

DUGGAN, Mark G. Hospital ownership and public medical spending. Quarterly Journal of Economics, v. 115, n. 4, p. 1343-1373, Nov. 2000.

DYE, Ronald A. An evaluation of essays on disclosure and the disclosure literature in accounting. Journal of Accounting and Economics, v. 32, p. 181-235, 2001.

DYL, Edward A. et al. Governance and funds allocation in United States medical research charities. Financial Accountability and Management in Governments, Public Services and Charities, n. 16, p. 335-352, 2000.

DYSON, R.G. et al. Pitfalls and protocols in DEA. European Journal of Operational Research, Amsterdam, v. 132, p. 245-259, 2001.

ENG, L. L.; MAK, Y. T. Corporate governance and voluntary disclosure. Journal of Accounting and Public Policy, n. 22, p. 325-345, 2003.

ERNEST \& YOUNG; FIPECAFI. Manual de normas internacionais de Contabilidade. São Paulo: Atlas, 2009.

FALCONER, Andres P. A promessa do terceiro setor: um estudo sobre a construção do papel das organizações sem fins lucrativos e do seu campo de gestão. São Paulo, 1999. Dissertação (Mestrado em Administração) - Faculdade de Economia, Administração e Contabilidade, Universidade de São Paulo. 
FARRELL, M. J. The measurement of productive efficiency. Journal of the Royal Statistical Society, Boston, Harvard Press, v. 120, p. 253-290, 1957.

FAVERO, Carlo; PAPI, Luca. Technical efficiency and scale efficiency in the Italian banking sector: a non-parametric approach. Applied Economics, v. 27, n. 4, p. 385-395, Apr. 1995.

FERNANDES, Rubem C. Privado porém público: o terceiro setor na América Latina. Rio de Janeiro: Relume Dumará, 1994.

FERRARI, Alfonso T. Metodologia da pesquisa científica. São Paulo: McGraw-Hill do Brasil, 1982.

FISCHER, Rosa M. O desafio da colaboração: práticas de responsabilidade social entre empresas e terceiro setor. São Paulo: Gente, 2002.

FIZEL, John L; NUNNIKHOVEN, Thomas S. The efficiency of nursing home chains. Applied Economics, v. 25, n. 1, p. 49-55, Jan. 1993.

FLACK, Ted. The mandatory disclosure of cost of fundraising ratios: does it achieve the regulators' purposes? Technical Report Working Paper nr. CPNS 26, Centre of Philanthropy and Non-profit Studies, Queensland University of Technology, 2004. Disponível em: $<$ http://eprints.qut.edu.au/archive/00004555/01/4555.pdf $>$. Acesso em: 11/06/2008.

; RYAN, Christine M. Financial reporting by Australian nonprofit organisations: dilemmas posed by government funders. Australian Journal of Public Administration, v. 64, n. 3, p. 69-77, 2005.

FLYNN, Patrice; HODGKINSON, Virginia A. The private nonprofit sector: measuring its impact on society. New York: Kluwer Academic, 2001.

FRANCIS, Jennifer et al. Voluntary disclosure, earnings quality, and cost of capital. Journal of Accounting Research, v. 46, n. 3, p. 53-99, Jan. 2008.

FRIEDMAN, Milton. The methodology of positive economics: essays in positive economics. Chicago: University of Chicago Press, 1953.

FROELICH, K. A. et al. Financial measure in nonprofit organization research: comparing IRS 990 returns and audited financial statement data. Nonprofit and Voluntary Sector Quarterly, n. 29, p. 232-254, 2000.

FRUMKIN, Peter. On being nonprofit: a conceptual and policy primer. Cambridge: Harvard University Press, 2002. 
FUNDO MONETÁRIO INTERNACIONAL - FMI. Global Financial Stability Report: responding to the financial crisis and measuring systemic risks. Washington: International Monetary Fund. Apr. 2009.

GANTZ, M. Who do you trust? Comparing data on skilled-nursing facilities from the Internal Revenue Service and health care financing administration. Nonprofit and Voluntary Sector Quarterly, n. 28, p. 476-490, 1999.

GATTOUFI, Said et al. Data envelopment analysis literature: a bibliography update (1951 2001). Socio-Economic Planning Sciences, v. 38, p. 159-229, 2004.

GIL, Antonio Carlos. Métodos e técnicas de pesquisa social. 5. ed. São Paulo: Atlas, 1999.

GLAESER, Edward. The governance of not-for-profit organizations. Chicago: The University of Chicago Press, 2003.

GOMES, Eliane G.; MANGABEIRA, João A. C. Uso de envoltória de dados em agricultura: o caso de Holambra. Revista de Engenharia da Universidade Federal Fluminense, Rio de Janeiro, v. 6. n. 1, p. 19-27, 2004.

GONZALEZ-ARAYA, M. C. Projeções não radiais em regiões fortemente eficientes da fronteira DEA: algoritmos e aplicações. Rio de Janeiro, 2003. Tese (Doutorado em Engenharia de Produção) - Universidade Federal do Rio de Janeiro/COPPE.

GORDON, T. et al. A comparative empirical examination of extent of disclosure by private and public colleges and universities in the United States. Journal of Accounting and Public Policy, v. 21, n. 3, p. 235-275, 2002.

et al. Tax exempt organization financial data: availability and limitations. Accounting Horizons, v. 13, p. 113-128, Jun. 1999.

GUJARATI, Damodar. Econometria básica. 14. ed. São Paulo: Campus, 2006.

GUO, Chao; SAXTON, Gregory. Accountability online: the web as an accountabilitybuilding tool for nonprofit organizations. The 9th National Public Management Research Conference, $2007 . \quad$ Disponível em: $<$ http://www.pmranet.org/conferences/AZU2007/ArizonaPapers/Guo\%20and\%20Saxton_200 7.pdf>. Acesso em: 23/05/2008.

HACKSTON, David; MILNE, Markus J. Some determinants of social and environment disclosures in New Zealand companies. Accounting, Auditing \& Accountability Journal, v. 9, n. 1, p. 77-108, 1996. 
HAIL, L. The impact of voluntary corporate disclosures on the ex-ante cost of capital for Swiss firms. European Accounting Review, v. 11, n. 4, p. 741-773, 2002.

HANDY, C. Understanding voluntary organizations. London: Penguin Books, 1990.

HANSMANN, Henry. The role of nonprofit enterprise. In: ROSE-ACKERMAN, Susan (Org.). The economics of nonprofit institutions: studies in structure and policy. New York: Oxford University Press, 1986. p. 57-84.

HEALY, Paul M.; PALEPU, Krishna G. Information asymmetry, corporate disclosure, and the capital markets: a review of the empirical disclosure literature. Journal of Accounting and Economics, v. 31, p. 405-440, 2001.

HENDRIKSEN, Eldon S.; VAN BREDA, Michael F. Teoria da contabilidade. São Paulo: Atlas, 1999.

HERLINZER, Regina E.; NITTERHOUSE, Denise. Financial accounting and managerial control for nonprofit organizations. Cincinnati: South-Western Publishing Co., 1994.

HOFMARCHER, Maria M. et al. Inefficiency in Austrian inpatient care: identifying ailing providers based on DEA research. Central European Journal of Operations Research, v. 13, n. 4, Dec. 2005.

HOLLAND, D. S.; LEE, S. T. Impacts of random noise and specification on estimates of capacity derived from data envelopment analysis. European Journal of Operational Research, v. 137, n. 1, p. 10-21, Feb. 2002.

HORNGREN, Charles T. et al. Contabilidade gerencial. 12. ed. São Paulo: Pearson, 2004.

HUDSON, Mike. Administrando organizações do terceiro setor. São Paulo: Pearson, 2004.

INSTITUTO BRASILEIRO DE GEOGRAFIA E ESTATÍSTICA - IBGE. As fundações privadas e associações sem fins lucrativos no Brasil. Brasília: IBGE, 2005.

. Indicadores sociodemográficos. Brasília: IBGE, 2006.

Pesquisa nacional por amostra de domicílios. Brasília: IBGE, 2007.

INSTITUTO DE PESQUISA ECONÔMICA APLICADA - IPEA. Radar social. Brasília: IPEA, 2005.

INTERNATIONAL ACCOUNTING STANDARD BOARD - IASB. Work plan: timetable as at 25 January 2009. Disponível em: 
$<$ http://www.iasb.org/Current+Projects/IASB+Projects/IASB+Work+Plan.htm>. Acesso em: 03/02/2009.

IPSOS-MARPLAN. O perfil do voluntariado. 2004. Disponível em: $<$ http://www.ipsos.com.br>. Acesso em: 10/01/09.

IUDÍCIBUS, Sérgio. Teoria da contabilidade. 6. ed. São Paulo: Atlas, 2000.

JAPIASSU, Hilton. Introdução ao pensamento epistemológico. 7. ed. Rio de Janeiro: Francisco Alves, 1992.

JEGERS, M. The economics of non profit accounting and auditing: suggestions for a research agenda. Annals of Public and Cooperative Economics. New York: v. 73, p.429-451, 2002.

JEMRIC, Igor; VUJCIC, Boris. Efficiency of banks in Croatia: a DEA approach. IFC Bulletin. $\quad$ n. 13, Dec. 2002. Disponível em: $<$ https://www.bis.org/ifc/publ/ifcb13.pdf?noframes=1>. Acesso em: 13/07/08.

JOBOME, Gregory O. Public funding, governance and passthrough efficiency in large UK Charities. Corporate Governance: an international review, v. 14, n. 1, p.43-59, Jan. 2006.

JUNQUEIRA, Luciano A. P. A gestão intersetorial das políticas sociais e o terceiro setor. Saúde e Sociedade, São Paulo, v. 13, n. 1, p. 25-36, Jan./Apr. 2004.

KEATING, Elizabeth K.; FRUMKIN, Peter. How to assess nonprofit financial performance. Working Paper, Kellogg Graduate School at Northwestern University and Hauser Center at Harvard University, 2001.

. Reengineering nonprofit financial accountability: toward a more reliable foundation for regulation. Public Administration Review, v. 63, n. 1, p. 3-15, 2003.

KEH, Hean T.; CHU, Singfat. Retail productivity and scale economies at the firm level: a DEA approach. Omega, v. 31, n. 2, p. 75-82, Apr. 2003.

KERLINGER, Fred N. Metodologia da pesquisa em ciências sociais. São Paulo: EDUSP, 1980.

KLEIN, A. Firm performance and board committee structure. Journal of Law \& Economics, n. 41, p. 275-303, 1998.

KOCHE, José C. Fundamentos de metodologia científica: teoria da ciência e prática da pesquisa. Petrópolis: Vozes, 1997. 
KORNAI, Janos. Economics of shortage. Amsterdam: North-Holland, 1980.

. The soft budget constraint. Kyklos, v. 39, n. 1, p. 801-819, 1986.

. et al. Understanding the soft budget constraint. Journal of Economic Literature, v. XLI, p. 1095-1136, Dec. 2003.

KOSTOVA, Tatiana; ROTH, Kendall; DACIN, Tina. Institutional theory in the study of multinational corporations: a critique and new directions. The Academy of Management Review (AMR), v. 33, n. 4, p. 994-1006, 2008.

KOTHARI, S. P. Capital markets research in accounting. Journal of Accounting and Economics, v. 31, p. 105-231, 2001.

KRISHNAN, R. et al. Expense misreporting in nonprofit organizations. The Accounting Review, v. 81, n. 2, p. 399-420, 2006.

KUHN, Thomas R. A estrutura das revoluções científicas. São Paulo: Perspectiva, 1987.

LADRIÉRE, Jean. Prefácio. In: BRUYNE, Paul de et al. Dinâmica da pesquisa em ciências sociais: os pólos da prática metodológica. 5. ed. Rio de Janeiro: Francisco Alves, 1991.

LAKATOS, Eva M.; MARCONI, Marina A. Metodologia científica. 3. ed. São Paulo: Atlas, 2000 .

LANDIM, Leilah. NGO's and philanthropy in Latin America: the Brazilian case. International Journal of Voluntary and Nonprofit Organizations. Voluntas. ISTR, v. 8, n. 4, 1997.

LANSINK, Alfonso et al. Effciency and productivity of conventional and organic farms in Finland 1994-1997. European Review of Agriculture Economics, v. 29, n. 1, p. 51-65, 2002.

LANZANA, Ana P. Relação entre disclosure e governança corporativa das empresas brasileiras. São Paulo, 2004. Dissertação (Mestrado em Administração) - Faculdade de Economia, Administração e Contabilidade, Universidade de São Paulo, 2004.

LeCLERC, Guy. et al. Accountability, performance reporting, comprehensive audit: an integrated perspective. Ottawa: Canadian Comprehensive Auditing Foundation, 1996.

LETA, F.R. et al. Métodos de melhora de ordenação em DEA aplicados à avaliação estática de tornos mecânicos. Investigação Operacional, Niterói, v. 25, n. 2, 2005. 
LI, David D.; LIANG, Minsong. Causes of the soft budget constraint: evidence on three explanations. Journal of Comparative Economics, v. 26, n. 1, p. 104-116, Mar. 1998.

LIGHT, Paul C. Pathways to nonprofit excellence. Washington, DC: Brookings Institution Press, 2002.

LINS, M. P. E.; ANGUlO MEZA, L. Análise envoltória de dados e perspectivas de integração no ambiente do apoio à decisão. Rio de Janeiro: Editora da COOPE/UFRJ, 2000 .

; MOREIRA, M. C. B. Método I - O stepwise para seleção de variáveis em modelos de análise envoltória dados. Pesquisa Operacional, Rio de Janeiro, v. 19, n. 1, p. 39-50, 1999.

LOPES, Alexsandro B. A relevância da informação contábil para o mercado de capitais: o modelo de Ohlson aplicado na Bovespa. São Paulo, 2001. Tese (Doutorado em Ciências Contábeis) - Faculdade de Economia, Administração e Contabilidade, Universidade de São Paulo.

MAGALHÃES, Gildo. Introdução à metodologia da pesquisa. São Paulo: Ática, 2005.

MARCONI, Marina; LAKATOS, Eva M. Técnicas de pesquisa. São Paulo: Atlas, 1996.

MARINHO, Alexandre. Estudo de eficiência em alguns hospitais públicos e privados com a geração de rankings. Textos para discussão n. 794. Rio de Janeiro: IPEA, 2001.

; FAÇANHA, Luis O. Programas sociais: efetividade, eficiência e eficácia como dimensões operacionais da avaliação. Textos para discussão n. 787. Rio de Janeiro: IPEA, 2001 .

McGUIGAN, James et al. Economia de empresas: aplicações, estratégias e táticas. São Paulo: Thomson, 2006.

MARTIN, Nilton C. Da controladoria à contabilidade: a evolução necessária. Revista Contabilidade e Finanças. São Paulo, Fipecafi, n. 28, p. 7-28, jan./abr. 2002.

MARTINS, Gilberto de Andrade. Manual para elaboração de monografias e dissertações. 2. ed. São Paulo: Atlas, 1994.

MASKIN, Eric. Recent theoretical work on the soft budget constraint. American Economic Review, v. 39, n. 2, p. 421-425, 1999.

; XU, Chenggang. Soft budget constraint theories: from centralization to the market.

Economics of Transition, v. 9, n. 1, p. 1-27, Mar. 2001. 
MEYER, John. W.; ROWAN, Brian. Institutionalized organizations: formal structure as myth and ceremony. American Journal of Sociology, v. 83, p. 340-363, 1977.

MILANI FILHO, Marco A. F. et al. O voluntariado nas entidades filantrópicas paulistanas: o valor não registrado contabilmente. Revista UnB Contábil. Brasília: Universidade de Brasília, v. 6, n. 1, p.153-172, 1. sem. 2003.

A função controladoria em entidades filantrópicas: uma contribuição para a avaliação de desempenho. São Paulo, 2004. Dissertação (Mestrado em Ciências Contábeis) Faculdade de Economia, Administração e Contabilidade, Universidade de São Paulo.

. Resultado econômico em organizações do Terceiro Setor: um estudo exploratório sobre a avaliação de desempenho. In: CONGRESSO USP DE CONTROLADORIA E CONTABILIDADE, 6., 2006, São Paulo. Anais... São Paulo: 2006.

- Responsabilidade social e investimento social privado: entre o discurso e a evidenciação. Revista Contabilidade e Finanças, São Paulo: Fipecafi, FEA/USP, n. 47, p. 89-101, mai./ago. 2008a.

Transparência e opacidade no terceiro setor: A Divulgação Financeira de Organizações Filantrópicas. In: CONGRESSO BRASILEIRO DE CUSTOS, 15., 2008, Curitiba. Anais... Curitiba: 2008b.

MINISTÉRIO DO DESENVOLVIMENTO SOCIAL - MDS. Cadastro das entidades beneficentes de assistência social com isenção da contribuição previdenciária. Brasília, 2009. Disponível em: <http://www020.dataprev.gov.br/pls/filantro/filan\$.startup>. Acesso em: 12/03/2009.

NAKAGAWA, Masayuki. Estudo de alguns aspectos de controladoria que contribuem para a eficácia gerencial. São Paulo, 1987. Tese (Doutorado em Ciências Contábeis) Faculdade de Economia, Administração e Contabilidade, Universidade de São Paulo, 1987.

NELSON, Morton. et al. Improved accountability disclosures by Canadian universities. Canadian Accounting Perspectives, v. 2, n. 1, p. 77-108, 2003.

NORMAN, M.; STOKER, B. Data envelopment analysis: the assessment of performance. New York: John Wiley and Sons, 1991.

O'DWYER, Brendan. Conceptions of corporate social responsibility: the nature of managerial capture. Accounting, Auditing \& Accountability Journal, v. 16, n. 4, p. 523$557,2003$.

OLAK, Paulo A. Contabilidade de entidades sem fins lucrativos não governamentais. São Paulo, 1996. Dissertação (Mestrado em Ciências Contábeis) - Faculdade de Economia, Administração e Contabilidade, Universidade de São Paulo, 1996. 
OLAK, Paulo A.; NASCIMENTO, Diogo T. Contabilidade para entidades sem fins lucrativos: terceiro setor. 2. ed. São Paulo: Atlas, 2008.

OLIVEIRA, Aristeu; ROMÃO, Valdo. Manual do terceiro setor e instituições religiosas. São Paulo: Atlas, 2006.

O'NEILL, Michael; FLETCHER, Kathleen. Nonprofit management education: U.S. and World perspectives. Westport: Praeger, 1998.

ORGANIZAÇÃO MUNDIAL DE SAÚDE - OMS. Health statistics annual: 1987. Disponível em: $<$ http://www.searo.who.int/LinkFiles/Country_Health_System_Profile_Definitions.pdf $>$. Acesso em: 04/05/2008.

. The world health report 2007 - a safer future: global public health security in the 21st century. 2007. Disponível em: <http://www.who.int/whr/2007/whr07_en.pdf $>$. Acesso em: 05/05/08.

ORGANIZAÇÃO DAS NAÇÕES UNIDAS - ONU. World population prospects: the 2000 Revision. 2001. Disponível em: $<$ http://www.un.org/esa/population/publications/wpp2000/wpp2000_volume3.htm>. Acesso em: 05/2008.

OZCAN, Yasar. Efficiency of hospital service production in local markets: the balance sheet of U.S. medical armament. Socio-Economic Planning Sciences, v. 29, n. 2, p. 139-150, Jun. 1995.

PAES, José E. Fundações e entidades de interesse social: aspectos jurídicos, administrativos e tributários. Brasília: Brasília Jurídica, 2001.

PATTON, Michael Q. Qualitative evaluation methods. Beverly Hills: Sage, 1980.

PERROW, Charles. Complex organizations: a critical essay. New York: McGraw-Hill, 1986.

POPPER, Karl R. Lógica da pesquisa científica. 9. ed. São Paulo: Cultrix, 2001.

QIAN, Yingyi; ROLAND, Gérard. Federalism and the soft budget constraint. American Economic Review, v. 88, n. 5, 1998.

RAISER, Martin. The no-exit economy: soft budget constraints and the fate of economic reforms in developing countries. World Development, v. 22, n. 12, p. 1851-1867, Dec. 1994. 
RAMANATHAN, K. Toward a theory of corporate social accounting. The Accounting Review, v. 51, n. 3, p. 516-528, July. 1976.

REIDER, Harry. Improving the economy, efficiency, and effectiveness of not-for-profit: conducting operational reviews. New York: John Wiley \& Sons, 2001.

RICHARDSON, Jarry R. Pesquisa social: métodos e técnicas. São Paulo: Atlas, 1999.

RIZZIERI, Juarez A. B. Introdução à economia. In: PINHO, D. B; VASCONCELLOS, M. A. S. Manual de economia. São Paulo: Saraiva, 1993.

ROSE-ACKERMAN, Susan (Org.). The economics of nonprofit institutions: studies in structure and policy. New York: Oxford University Press, 1986.

RUDIO, Franz V. Introdução ao projeto de pesquisa científica. São Paulo: Vozes, 2002.

SALAMON, Lester M. Partners in public service: government-nonprofit relations in the modern welfare state. Baltimore: The Johns Hopkins University Press, 1995.

. et al. (Org.). Global civil society: dimensions of the nonprofit sector. Baltimore: The Johns Hopkins Center for Civil Society Studies, 1999.

; TOEPLER, S. The influence of the legal environment on the development of the nonprofit sector. Baltimore: Center for Civil Society Studies, Working Paper Series n. 17, The Johns Hopkins University Institute for Policy Studies, 2000.

SAMUELSON, Paul A.; NORDHAUS, William D. Economia. Rio de Janeiro: McGraw-Hill, 2004.

SCOTT, W. R. Institutions and organizations. Thousand Oaks: Sage, 1995.

SEIFORD, L.M. A bibliography for data envelopment analysis (1978-1996). Annals of Operations Research. n. 73, p. 393-438, 1997.

SELZNICK, P. Leadership in administration: a sociological interpretation New York: Harper \& Row, 1957.

SEN, Amartya. Desenvolvimento como liberdade. São Paulo: Companhia das Letras. 2004.

SENGUPTA, Jati; SAHOO, Biresh. Efficiency models in data envelopment analysis: techniques of evaluation of productivity of firms in a growing economy. New York: Palgrave Macmillan, 2006. 
SENRA, Luiz F.A.C. et al. Estudo sobre métodos de seleção de variáveis em DEA. Pesquisa Operacional, v. 27, n. 2, p. 191-207, 2007.

SHIM, Jae K.; SIEGEL, Joel G. Financial management for nonprofits. New York: McGraw-Hill, 1997.

SILVA, Ligia M; FORMIGLI, Vera L. Avaliação em saúde: limites e perspectivas. Cadernos de Saúde Pública, v. 10, n. 1, p. 80-91, Jan./Mar. 1994.

SLACK, Trevor; HININGS, Bob. Institutional pressures and isomorphic change: an empirical test. Organization Studies, v. 15, n. 6, p. 803-827, 1994.

SLOAM, Richard G. Financial accounting and corporate governance: a discussion. Journal of Accounting and Economics, v. 32, n. 1-3, p. 335-347, Dec. 2001.

SLOMSKI, Valmor. Mensuração do resultado econômico nas entidades públicas: uma proposta. São Paulo, 1996. Dissertação (Mestrado em Ciências Contábeis) - Faculdade de Economia, Administração e Contabilidade, Universidade de São Paulo.

SOARES DE MELLO, J. C. C. B. et al. Método multicritério para seleção de variáveis em modelos DEA. Pesquisa Naval, Rio de Janeiro, n. 15, p. 55-66, 2002. $103,2005$.

et al. Fronteiras DEA difusas. Investigação Operacional, Niterói, v. 25, n. 1, p. 85-

SZAZI, Eduardo. Terceiro setor: regulação no Brasil. 4. ed. São Paulo: Peirópolis, 2006.

TELLES, Vera da Silva. Movimentos sociais: reflexões sobre a experiência dos anos 70. In: SCHERER-WARREN, I; KRISCHKE, P. J. (Orgs.). Uma revolução no cotidiano? Os novos movimentos sociais na América do Sul. São Paulo: Brasiliense, 1987.

THEÓPHILO, Carlos R. Pesquisa em contabilidade no Brasil: uma análise críticoepistemológica. São Paulo, 2004. Tese (Doutorado) - Faculdade de Economia, Administração e Contabilidade da Universidade de São Paulo.

TILT, Carol A. The influence of external pressure groups on corporate social disclosure: some empirical evidence. Accounting, Auditing and Accountability Journal, v. 7, n. 4, p. 47-72, 1994.

TODER, C. Not-for-profit financial reporting. CPA Journal, n. 10, Mar. 2006.

TOLBERT, Pamela S.; ZUCKER, Iynne G. A institucionalização da teoria institucional. In: CLEGG, Stewart R.; HARDY, Cynthia; NORD, Walter R. Handbook de estudos 
organizacionais: modelos de análise e novas questões em estudos organizacionais. São Paulo: Atlas, 1999 (v.1, cap. 6, p. 196-219).

TONGEL, Marsha; PETRESCU, Claudia. High performance in nonprofit organizations in the Greater Pittsburgh Area. Tropman Fund for Nonprofit Research, 2004. Disponível em: $<$ www.forbesfunds.org/docs/TongelPetrescuFullReport_TR04.pdf>. Acesso em: 31/03/2007.

ULLMANN, A. Data in search of a theory: a critical examination of the relationships among social performance, social disclosure, and economic performance of US firms. The Academy of Management Review, v. 10, n. 3, p. 540-557, July. 1985.

VARIAN, Hal R. Microeconomia. São Paulo: Elsevier, 2003.

VERAS, Renato P. et al. Características demográficas dos idosos vinculados ao sistema suplementar de saúde no Brasil. Revista de Saúde Pública, São Paulo, v. 42, n. 3, Jun. 2008.

VERRECHIA, Robert E. Essays on disclosure. Journal of Accounting and Economics, v. 32, p. 97-180, 2001.

YAMADA, Y. et al. New analysis of efficiency based on DEA. Journal of the Operations Research Society of Japan, v. 37, n. 2, p. 158-167, 1994.

WATTS, R.; ZIMMERMAN, J. Positive accounting theory: a ten year perspective. The Accounting Review, v. 65, n. 1, p. 131-157, 1990.

WEISBROD, Burton. The nonprofit economy. Cambridge: Harvard University Press, 1988.

; SCHLESINGER, Mark. Public, private, nonprofit ownership and the response to asymmetric information: the case of nursing homes. In: ROSE-ACKERMAN, Susan (Org.). The economics of nonprofit institutions: studies in structure and policy. New York: Oxford University Press, 1986.

WILDEMUTH, Barbara M. Post-positivist research: two examples of methodological pluralism. Library Quarterly, v. 63, n. 4, p. 450-468, Oct. 1993.

WOLF, Thomas. Managing a nonprofit organization. 3rd ed. New York: Simon \& Schuster Inc., 1999. 


\section{APÊNDICES}

APÊNDICE 1 - Relação de ILPIs filantrópicas paulistas

APÊNDICE 2 - Carta de apresentação da pesquisa e questionário

APÊNDICE 3 - Valores-alvo para as ILPIs 
APÊNDICE 1 - Relação das ILPIs fillantrópicas paulistas

\begin{tabular}{|c|c|}
\hline ILPIs Filantrópicas Paulistas & Cidade \\
\hline LAR DOS VELHOS & ADAMANTINA \\
\hline LAR DOS VELHINHOS DE S VICENTE DE PAULO DE AMERICANA & AMERICANA \\
\hline LAR DOS VELHOS DE AMPARO & AMPARO \\
\hline LAR DA VELHICE E ASSISTENCIA SOCIAL & ARACATUBA \\
\hline AIDAN - ASSIST.IDOSOS DESAMPARADOS ARTUR NOGUEIRA & ARTUR NOGUEIRA \\
\hline ASSOC ABRIGO A IDOSOS RV GUILHERME R PEREIRA & ASSIS \\
\hline LAR DOS VELHOS-OBRA UNIDA A SOC SAO VICENTE DE PAULO & ASSIS \\
\hline CENTRO ESPIRITA CRISTAO LAR AMPARO VELHICE INF & BARRA BONITA \\
\hline VILA VICENTINA ABRIGO PARA VELHOS & BAURU \\
\hline LAR DOS VELHOS SAO CAMILO DE LELIS & BURITAMA \\
\hline LAR DOS VELHOS DE CAJURU & CAJURU \\
\hline LAR DOS VELHINHOS DE CAMPINAS & CAMPINAS \\
\hline PROJETO ANCORA P/ DIREITOS DA CRIANCA, ADOLESC E IDOSOS & COTIA \\
\hline CASA DOS VELHOS OBRA UNIDA A SOC SAO VICENTE DE PAULO & DRACENA \\
\hline RECANTO VICENTINO ABRIGO PARA VELHOS & DUARTINA \\
\hline LAR DA TERCEIRA IDADE DA ASSISTENCIA VICENTINA & ESPIRITO STO DO PINHAL \\
\hline CASA DOS VELHOS IRMA ALICE & GUARULHOS \\
\hline DISPENSARIO ASSIST POBRES ABRIGO VELHOS DESAMPARADOS & IGARAPAVA \\
\hline ABRIGO DE IDOSOS COMENDADOR TAKA YUKI MAEDA & ITUVERAVA \\
\hline LAR DOS VELHINHOS SAO VICENTE DE PAULO & JALES \\
\hline ASSOCIACAO LAR PARA OS VELHOS SAO JOAO & JOSE BONIFACIO \\
\hline SOCIEDADE BENEFICIENTE DE AMPARO A VELHICE & MACATUBA \\
\hline LAR DA TERCEIRA IDADE PADRE LONGINO & MOGI-GUACU \\
\hline LAR DOS VELHINHOS BEZERRA DE MENEZES & NHANDEARA \\
\hline LAR DE VELHICE MARIA DE SOUZA SPINOLA & NOVO HORIZONTE \\
\hline LAR DOS VELHOS ANTONIO FREDERICO OZANAM & PANORAMA \\
\hline LAR DOS VELHOS DE PARAPUA & PARAPUA \\
\hline LAR DOS VELHINHOS DE PEDREGULHO & PEDREGULHO \\
\hline LAR DOS VELHOS FLAMINIO MAURICIO & PEDREIRA \\
\hline LAR DE VELHOS SAO VICENTE DE PAULO OBRA UNIDA A SSVP & PINDAMONHANGABA \\
\hline LAR DOS VELHINHOS DE PIRACICABA & PIRACICABA \\
\hline LAR DE IDOSOS SAO VICENTE DE PAULO DE PIRAJUI & PIRAJUI \\
\hline ASILO DE VELHICE E MENDICIDADE NOSSA SENHORA DE FATIMA & PIRASSUNUNGA \\
\hline VILA VICENTINA DOS VELHOS DESAMPARADOS & PIRATININGA \\
\hline LAR DOS IDOSOS ANTONIO FREDERICO OZANAM & POMPEIA \\
\hline CIDADE DOS VELHINHOS DE PORTO FELIZ & PORTO FELIZ \\
\hline LAR DOS VELHOS DE S.VICENTE DE PAULO DE PRES.BERNARDES & PRESIDENTE BERNARDES \\
\hline RECANTO DOS IDOSOS SAO VICENTE DE PAULO DE RANCHARIA & RANCHARIA \\
\hline SOCIEDADE DE PROTECAO A VELHICE LAR PADRE GEREMIAS & REGINOPOLIS \\
\hline LAR DOS VELHOS MARIA AFRA TOSTES OBRA UNIDA DA SSVP & RIBEIRAO BONITO \\
\hline LAR DOS VELHOS DA IGREJA PRESBITERIANA & RIBEIRAO PRETO \\
\hline ABRIGO DA VELHICE SAO VICENTE DE PAULO & RIO CLARO \\
\hline
\end{tabular}

(continua) 


\begin{tabular}{ll}
\hline \multicolumn{1}{c}{ ILPI's - Continuação } & Cidade \\
\hline LAR DOS VELHINHOS DECOLORES DE SANTA ADELIA & SANTA ADELIA \\
LAR DOS VELHINHOS SAO VICENTE DE PAULO & SANTA FE DO SUL \\
LAR EVANGELICO DE AMPARO A VELHICE & SANTOS \\
CASA DE S VICENTE DE PAULO JARDIM DOS VELHINHOS DO ABC & SAO BERN. DO CAMPO \\
ABRIGO IRMA TEREZA A VELHICE DESAMPARADA & SAO CAETANO DO SUL \\
CIDADE DOS VELHINHOS SANTA LUISA DE MARILAC & SAO PAULO \\
ABRIGO DOS VELHINHOS FREDERICO OZANAM & SAO PAULO \\
SOC RELIGIOSA E BENEFICENTE ISRAELITA LAR DOS VELHOS & SAO PAULO \\
CASA DOS VELHINHOS DE SAO PEDRO & SAO PEDRO \\
ASILO DOS VELHOS JOSE FRANCO CRA VEIRO & SOCORRO \\
VILA DOS VELHINHOS DE SOROCABA & SOROCABA \\
ASILO DE VELHOS JOSE SOLER & TABATINGA \\
CASA SAO FRANCISCO DE IDOSOS DE TAUBATE & TAUBATE \\
LAR DE VELHICE E MENDICIDADE DE TORRINHA & TORRINHA \\
INSTITUICAO CASA DOS VELHOS & TUPA \\
RECANTO DOS VELHINHOS DE VALINHOS & VALINHOS \\
LAR DO VELHINHO DE VOTUPORANGA & VOTUPORANGA \\
\hline
\end{tabular}




\section{APÊNDICE 2}

\section{UNIVERSIDADE DE SÃO PAULO}

FACULDADE DE ECONOMIA, ADMINISTRAC̄̃̃O E CONTABILIDADE

PROGRAMA DE PÓS-GRADUAÇÃO EM CONTROLADORIA E CONTABILIDADE

$\grave{A}$

S.Paulo, de de 2009

$\operatorname{Sr}(\mathrm{a})$

\section{SOLICITAÇÃO DE DADOS - ILPI \\ Pesquisa Acadêmica}

Prezado(a) Senhor(a),

Estamos desenvolvendo uma pesquisa acadêmica sobre os indicadores de desempenho das Instituições de Longa Permanência para Idosos - ILPI - localizadas no Estado de São Paulo e, nesse sentido, entramos em contato para solicitar a vossa participação.

\section{Objetivos da pesquisa}

- Estimar o desempenho das ILPIs paulistas, com base nos indicadores definidos pela resolução 283 da ANVISA.

- Caracterizar as principais informações divulgadas publicamente pelas ILPIs

\section{$\underline{\text { Metodologia }}$}

- Pesquisa exploratória, quantitativa e empírico-analítica.

- Técnicas estatísticas: Descritiva e Análise Envoltória de Dados.

- Amostragem probabilística.

- Coleta de dados primários e secundários.

\section{Outras características relevantes da pesquisa}

- O estudo possui caráter exclusivamente acadêmico, sem qualquer outro tipo de interesse.

- Os resultados obtidos poderão ser compartilhados com as entidades participantes.

Contamos com o vosso auxílio neste estudo, respondendo o questionário em anexo e o enviando para o seguinte e-mail: mmilani@usp.br

Desde já, nos colocamos à disposição para qualquer esclarecimento adicional que se fizer necessário.

Prof. Ms. Marco Antonio F. Milani Filho

Doutorando em Controladoria - FEA/USP
Prof. Dr. Welington Rocha

Departamento de Contabilidade - FEA/USP 


\section{QUESTIONÁRIO \\ Pesquisa Acadêmica}

- Por favor, informe os dados solicitados nos Quadros 1, 2, 3 e 4.

- As informações serão tratadas com confidencialidade

- Sua participação é muito importante.

Quadro 1 - Informações sobre a estrutura

\begin{tabular}{|c|c|c|c|}
\hline $\mathrm{N}^{\mathrm{o}}$ & Dados quantitativos & Tipo & Total \\
\hline \multirow{3}{*}{1} & \multirow{3}{*}{$\mathrm{N}^{\mathrm{o}}$ de leitos disponíveis } & para residentes Grau I ${ }^{\mathrm{a}}$ & \\
\hline & & para residentes Grau II $^{b}$ & \\
\hline & & para residentes Grau $\mathrm{III}^{\mathrm{c}}$ & \\
\hline \multirow{3}{*}{2} & \multirow{3}{*}{$\mathrm{N}^{\mathrm{o}}$ de leitos ocupados (média mensal) } & por residentes Grau I ${ }^{\mathrm{a}}$ & \\
\hline & & por residentes Grau $\mathrm{II}^{\mathrm{b}}$ & \\
\hline & & 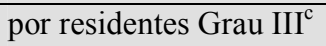 & \\
\hline 3 & $\mathrm{~N}^{\circ}$ de funcionários remunerados & média mensal & \\
\hline \multirow{2}{*}{4} & $\mathrm{~N}^{\circ}$ de voluntários & média mensal & \\
\hline & $\mathrm{N}^{\mathrm{o}}$ de horas doadas por voluntários & média mensal & \\
\hline 5 & $\mathrm{~N}^{\mathrm{o}}$ de cuidadores & média mensal & \\
\hline
\end{tabular}

\section{NOTAS}

a) Grau I - pessoas independentes, mesmo que requeiram uso de equipamentos de auto-ajuda;

b) Grau II - pessoas sem comprometimento cognitivo ou com alteração cognitiva controlada, mas com dependência em até três atividades de autocuidado para a vida diária, tais como: alimentação, mobilidade, higiene;

c) Grau III - pessoas com dependência que necessitem de assistência diária para a realização de todas as atividades de autocuidado e/ou com comprometimento cognitivo 
Quadro 2 - Indicadores ANVISA

\begin{tabular}{|c|c|c|c|}
\hline $\mathrm{N}^{\mathrm{o}}$ & Indicador & Fórmula e Unidade & $\%$ \\
\hline 1 & $\begin{array}{c}\text { Taxa de mortalidade em idosos } \\
\text { residentes }\end{array}$ & $\begin{array}{c}\text { (Número de óbitos de idosos residentes no mês } \\
\text { / Número de idosos residentes no mês }{ }^{1} \text { ) } 100 \\
{[\%]}\end{array}$ & \\
\hline 2 & $\begin{array}{l}\text { Taxa incidência }{ }^{2} \text { de doença } \\
\text { diarréica aguda }{ }^{3} \text { em idosos } \\
\text { residentes }\end{array}$ & $\begin{array}{l}\text { (Número de novos casos de doença diarréica } \\
\text { aguda em idosos residentes no mês / Número de } \\
\text { idosos residentes no mês }{ }^{1} \text { ) }{ }^{*} 100[\%]\end{array}$ & \\
\hline 3 & $\begin{array}{c}\text { Taxa de incidência de escabiose } \\
\text { em idosos residentes }\end{array}$ & $\begin{array}{l}\text { (Número de novos casos de escabiose em } \\
\text { idosos residentes no mês / Número de idosos } \\
\left.\text { residentes no mês }{ }^{1}\right) * 100[\%]\end{array}$ & \\
\hline 4 & $\begin{array}{l}\text { Taxa de incidência de } \\
\text { desidratação } 5 \text { em idosos } \\
\text { residentes }\end{array}$ & $\begin{array}{c}\text { (Número de idosos que apresentaram } \\
\text { desidratação / Número de idosos residentes no } \\
\left.\text { mês }^{1}\right) * 100[\%]\end{array}$ & \\
\hline 5 & $\begin{array}{l}\text { Taxa de prevalência }{ }^{6} \text { de úlcera de } \\
\text { decúbito em idosos residentes }\end{array}$ & $\begin{array}{l}\text { (Número de idosos residentes apresentando } \\
\text { úlcera de decúbito no mês/ Número de idosos } \\
\left.\text { residentes no mês }{ }^{1}\right) * 100[\%]\end{array}$ & \\
\hline 6 & $\begin{array}{c}\text { Taxa de prevalência de } \\
\text { desnutrição }{ }^{7} \text { em idosos residentes }\end{array}$ & $\begin{array}{c}\text { (Número de idosos residentes com diagnóstico } \\
\text { de desnutrição no mês/ Número de idosos } \\
\left.\text { residentes no mês }{ }^{1}\right) * 100[\%]\end{array}$ & \\
\hline
\end{tabular}

\section{NOTAS}

1 - População exposta: considerar o número de idosos residentes do dia 15 de cada mês.

2 - Taxa de incidência: é uma estimativa direta da probabilidade ou risco de desenvolvimento de determinada doença em um período de tempo específico; o numerador corresponde aos novos casos, ou seja, aqueles iniciados no período em estudo.

3- Doença diarréica aguda: Síndrome causada por vários agentes etiológicos (bactérias, vírus e parasitas), cuja manifestação predominante é o aumento do número de evacuações, com fezes aquosas ou de pouca consistência. Com freqüência, é acompanhada de vômito, febre e dor abdominal. Em alguns casos, há presença de muco e sangue. No geral, é autolimitada, com duração entre 2 e 14 dias. As formas variam desde leves até graves, com desidratação e distúrbios eletrolíticos, principalmente quando associadas à desnutrição prévia.

4- Escabiose: parasitose da pele causada por um ácaro cuja penetração deixa lesões em forma de vesículas, pápulas ou pequenos sulcos, nos quais ele deposita seus ovos.

5- Desidratação: (perda de água) Falta de quantidade suficiente de líquidos corpóreos para manter as funções normais em um nível adequado. Deficiência de água e eletrólitos corpóreos por perdas superiores à ingestão. Pode ser causada por: ingestão reduzida (anorexia, coma e restrição hídrica); perda aumentada gastrointestinal (vômitos e diarréia), ou urinária (diurese osmótica, administração de diuréticos, insuficiência renal crônica e da supra-renal), ou cutânea e respiratória (queimaduras e exposição ao calor).

6 - Taxa de prevalência: mede o número de casos presentes em um momento ou em um período específico; o numerador compreende os casos existentes no início do período de estudo, somados aos novos casos.

7 - Desnutrição: Condição causada por ingestão ou digestão inadequada de nutrientes. Pode ser causada pela ingestão de uma dieta não balanceada, problemas digestivos, problemas de absorção ou problemas similares. É a manifestação clínica decorrente da adoção de dieta inadequada ou de patologias que impedem o aproveitamento biológico adequado da alimentação ingerida.” (ANVISA, 2005). 
Quadro 3 - Informações financeiras

\begin{tabular}{|c|c|c|c|}
\hline $\begin{array}{c}\mathrm{N} \\
\mathrm{o}\end{array}$ & Dados quantitativos & Fontes & Total R\$ \\
\hline 1 & Valor do Ativo Permanente & Balanço Patrimonial (último exercício) & \\
\hline 2 & Despesas correntes totais & Demonstração do Superávit do exercício & \\
\hline 3 & $\begin{array}{c}\text { Total recebido de fontes públicas } \\
\text { (subvenções, doações e outras receitas } \\
\text { de órgãos governamentais) }\end{array}$ & $\begin{array}{c}\text { Demonstração do Superávit do exercício / Notas } \\
\text { explicativas / Controles gerenciais }\end{array}$ & \\
\hline 4 & $\begin{array}{l}\text { Total recebido pela prestação de } \\
\text { serviços e outras receitas comerciais }\end{array}$ & $\begin{array}{c}\text { Demonstração do Superávit do exercício / Notas } \\
\text { explicativas / Controles gerenciais }\end{array}$ & \\
\hline 5 & $\begin{array}{c}\text { Total recebido de fontes privadas } \\
\text { (doações e outras transferências não- } \\
\text { comerciais) }\end{array}$ & $\begin{array}{c}\text { Demonstração do Superávit do exercício / Notas } \\
\text { explicativas / Controles gerenciais }\end{array}$ & \\
\hline
\end{tabular}

\section{Quadro 4 - Práticas sobre a divulgação de informações}

\begin{tabular}{|c|c|c|c|c|}
\hline $\begin{array}{c}\mathrm{N} \\
\mathbf{0}\end{array}$ & Questões & SIM & NÃO & Observações \\
\hline \multirow{2}{*}{1} & \multirow{2}{*}{$\begin{array}{c}\text { A instituição divulga informações pela } \\
\text { Internet? }\end{array}$} & & & $\begin{array}{l}\text { Em caso afirmativo, favor informar o endereço } \\
\text { eletrônico. }\end{array}$ \\
\hline & & & & \\
\hline \multirow{2}{*}{2} & \multirow{2}{*}{$\begin{array}{l}\text { As demonstrações financeiras são } \\
\text { publicadas regularmente? }\end{array}$} & & & $\begin{array}{l}\text { Em caso afirmativo, favor informar a data, o } \\
\text { local e o meio de comunicação. }\end{array}$ \\
\hline & & & & \\
\hline \multirow[t]{2}{*}{3} & \multirow{2}{*}{$\begin{array}{l}\text { As demonstrações financeiras são } \\
\text { enviadas a grupos ou a pessoas } \\
\text { regularmente? }\end{array}$} & & & $\begin{array}{c}\text { Em caso afirmativo, favor informar a freqüência } \\
\text { do envio e que grupo de pessoas recebe essas } \\
\text { demonstrações. }\end{array}$ \\
\hline & & & & \\
\hline \multirow{2}{*}{4} & \multirow{2}{*}{$\begin{array}{c}\text { As informações contábeis estão } \\
\text { disponíveis para consulta por pessoas } \\
\text { externas à instituição? }\end{array}$} & & & $\begin{array}{l}\text { Em caso afirmativo, favor informar o cargo do } \\
\text { responsável para essa solicitação de consulta. }\end{array}$ \\
\hline & & & & \\
\hline 5 & $\begin{array}{l}\text { As demonstrações contábeis são } \\
\text { acompanhadas de Notas Explicativas? }\end{array}$ & & & \\
\hline \multirow{2}{*}{6} & \multirow{2}{*}{$\begin{array}{l}\text { A instituição divulga ou disponibiliza } \\
\text { um relatório de atividades? }\end{array}$} & & & $\begin{array}{l}\text { Em caso afirmativo, favor informar o meio de } \\
\text { divulgação e a freqüência. }\end{array}$ \\
\hline & & & & \\
\hline \multirow{2}{*}{7} & \multirow{2}{*}{$\begin{array}{l}\text { A missão da organização é divulgada } \\
\text { publicamente? }\end{array}$} & & & $\begin{array}{l}\text { Em caso afirmativo, favor informar o meio de } \\
\text { divulgação. }\end{array}$ \\
\hline & & & & \\
\hline
\end{tabular}

(CONTINUA) 
Quadro 4 - Práticas sobre a divulgação de informações (continuação)

\begin{tabular}{|c|l|c|c|}
\hline $\mathrm{N}^{\circ}$ & \multicolumn{1}{|c|}{ As informações abaixo são disponibilizadas ao público? } & SIM & NÃO \\
\hline 8 & História da entidade & & \\
\hline 9 & Descrição dos serviços prestados & & \\
\hline 10 & Metas e objetivos & & \\
\hline 11 & Fatores críticos de sucesso & & \\
\hline 12 & Eventos importantes no ano & & \\
\hline 13 & Estrutura organizacional & & \\
\hline 14 & Investimentos em recursos humanos & & \\
\hline 15 & Sumário dos resultados históricos & & \\
\hline 16 & Custos da atividade de captação de recursos & & \\
\hline 17 & Evidenciação dos recursos com finalidade exclusiva & & \\
\hline 18 & Número de funcionários remunerados & & \\
\hline 19 & Número de voluntários e horas dedicadas por período & & \\
\hline 20 & Satisfação dos usuários dos serviços & & \\
\hline 21 & Satisfação dos funcionários & & \\
\hline 22 & Políticas e projetos e investimentos & & \\
\hline 23 & Resultados e desempenhos projetados & & \\
\hline 24 & Informações gerais disponíveis em website & & \\
\hline
\end{tabular}

Pedimos a gentileza de enviar o questionário preenchido para mmilani@usp.br até / / . 


\section{APÊNDICE 3 - ALVOS}

DMU_1 (eficiência:0,641296 )

\begin{tabular}{|c|c|c|c|}
\hline Variável & Atual & Folga & Alvo \\
\hline Input_1 & 95,00 & - & 60,92 \\
\hline Input_2 & $50.134,13$ & $20.460,39$ & $11.690,41$ \\
\hline Input_3 & $11.390,76$ & 324,55 & $6.980,29$ \\
\hline Output_1 & 99,00 & 0,04 & 99,04 \\
\hline Output_2 & 97,00 & 1,00 & 98,00 \\
\hline Output_3 & 100,00 & - & 100,00 \\
\hline Output_4 & 96,80 & 2,20 & 99,00 \\
\hline Output_5 & 96,00 & 4,00 & 100,00 \\
\hline Output 6 & 97,20 & 1,00 & 98,20 \\
\hline
\end{tabular}

DMU_2 (eficiência:1,000000)

\begin{tabular}{|c|c|c|c|c|}
\hline Variável & Atual & Folga & & Alvo \\
\hline Input_1 & 118,10 & & - & 118,10 \\
\hline Input_2 & $20.468,89$ & & - & $20.468,89$ \\
\hline Input_3 & $14.103,98$ & & - & $14.103,98$ \\
\hline Output_1 & 99,08 & & - & 99,08 \\
\hline Output_2 & 99,23 & & - & 99,23 \\
\hline Output_3 & 100,00 & & - & 100,00 \\
\hline Output_4 & 100,00 & & - & 100,00 \\
\hline Output_5 & 99,25 & & - & 99,25 \\
\hline Output_6 & 100,00 & & - & 100,00 \\
\hline \multicolumn{5}{|c|}{ DMU_3 (eficiência:1,000000) } \\
\hline Variável & Atual & Folga & & Alvo \\
\hline Input_1 & 60,92 & & - & 60,92 \\
\hline Input_2 & $11.690,41$ & & - & $11.690,41$ \\
\hline Input_3 & $6.980,29$ & & - & $6.980,29$ \\
\hline Output_1 & 99,04 & & - & 99,04 \\
\hline Output_2 & 98,00 & & - & 98,00 \\
\hline Output_3 & 100,00 & & - & 100,00 \\
\hline Output_4 & 99,00 & & - & 99,00 \\
\hline Output_5 & 100,00 & & - & 100,00 \\
\hline Output_6 & 98,20 & & - & 98,20 \\
\hline \multicolumn{5}{|c|}{ DMU_4 (eficiência:1,000000) } \\
\hline Variável & Atual & Folga & & Alvo \\
\hline Input_1 & 117,28 & & - & 117,28 \\
\hline Input_2 & $5.526,06$ & & - & $5.526,06$ \\
\hline Input_3 & $8.201,16$ & & - & $8.201,16$ \\
\hline Output_1 & 98,33 & & - & 98,33 \\
\hline Output_2 & 99,58 & & - & 99,58 \\
\hline Output_3 & 99,31 & & - & 99,31 \\
\hline Output_4 & 99,44 & & - & 99,44 \\
\hline Output_5 & 99,93 & & - & 99,93 \\
\hline Output_6 & 97,00 & & - & 97,00 \\
\hline
\end{tabular}


Alvos

DMU 5 (eficiência:1,000000)

\begin{tabular}{lrrrr} 
Variável & Atual & Folga & \multicolumn{2}{r}{ Alvo } \\
Input_1 & 221,67 & & - & 221,67 \\
Input_2 & $6.506,67$ & - & $6.506,67$ \\
Input_3 & $24.979,49$ & - & $24.979,49$ \\
Output_1 & 100,00 & - & 100,00 \\
Output_2 & 99,00 & - & 99,00 \\
Output_3 & 100,00 & - & 100,00 \\
Output_4 & 100,00 & - & 100,00 \\
Output_5 & 99,90 & - & 99,90 \\
Output_6 & 100,00 & - & 100,00
\end{tabular}

DMU_6 (eficiência:1,000000 )

\begin{tabular}{|c|c|c|c|}
\hline Variável & Atual & Folga & Alvo \\
\hline Input_1 & 107,80 & - & 107,80 \\
\hline Input_2 & $10.954,12$ & - & $10.954,12$ \\
\hline Input_3 & $13.793,07$ & - & $13.793,07$ \\
\hline Output_1 & 99,00 & - & 99,00 \\
\hline Output_2 & 99,00 & - & 99,00 \\
\hline Output_3 & 100,00 & - & 100,00 \\
\hline Output_4 & 99,00 & - & 99,00 \\
\hline Output_5 & 100,00 & - & 100,00 \\
\hline Output_6 & 100,00 & - & 100,00 \\
\hline
\end{tabular}

DMU_7 (eficiência:1,000000)

\begin{tabular}{|c|c|c|c|}
\hline Variável & Atual & Folga & Alvo \\
\hline Input_1 & 64,39 & - & 64,39 \\
\hline Input_2 & $2.815,69$ & - & $2.815,69$ \\
\hline Input_3 & $5.223,50$ & - & $5.223,50$ \\
\hline Output_1 & 97,60 & - & 97,60 \\
\hline Output_2 & 99,00 & - & 99,00 \\
\hline Output_3 & 99,18 & - & 99,18 \\
\hline Output_4 & 100,00 & - & 100,00 \\
\hline Output_5 & 97,60 & - & 97,60 \\
\hline Output_6 & 97,60 & - & 97,60 \\
\hline \multicolumn{4}{|c|}{ DMU_8 (eficiência:0,859082 ) } \\
\hline Variável & Atual & Folga & Alvo \\
\hline Input_1 & 80,45 & - & 69,12 \\
\hline Input_2 & $33.451,18$ & $21.883,47$ & $6.853,83$ \\
\hline Input_3 & $8.300,25$ & - & $7.130,59$ \\
\hline Output_1 & 99,02 & - & 99,02 \\
\hline Output_2 & 98,49 & 0,12 & 98,60 \\
\hline Output_3 & 99,40 & 0,05 & 99,45 \\
\hline Output_4 & 99,18 & - & 99,18 \\
\hline Output_5 & 99,33 & 0,16 & 99,48 \\
\hline Output_6 & 98,87 & - & 98,87 \\
\hline
\end{tabular}


Alvos

DMU_9 (eficiência:1,000000)

\begin{tabular}{lrrrr} 
Variável & Atual & Folga & \multicolumn{2}{r}{ Alvo } \\
Input_1 & 443,37 & & - & 443,37 \\
Input_2 & $173.831,33$ & - & $173.831,33$ \\
Input_3 & $46.500,78$ & - & $46.500,78$ \\
Output_1 & 98,70 & - & 98,70 \\
Output_2 & 99,19 & - & 99,19 \\
Output_3 & 99,84 & - & 99,84 \\
Output_4 & 99,69 & - & 99,69 \\
Output_5 & 99,61 & - & 99,61 \\
Output_6 & 100,00 & - & 100,00
\end{tabular}

DMU_10 (eficiência:1,000000)

$\begin{array}{lrrrr}\text { Variável } & \text { Atual } & \text { Folga } & & \text { Alvo } \\ \text { Input_1 } & 102,90 & & - & 102,90 \\ \text { Input_2 } & 3.090,88 & - & 3.090,88 \\ \text { Input_3 } & 9.555,59 & - & 9.555,59 \\ \text { Output_1 } & 98,76 & - & 98,76 \\ \text { Output_2 } & 99,78 & - & 99,78 \\ \text { Output_3 } & 99,31 & - & 98,31 \\ \text { Output_4 } & 99,44 & - & 99,44 \\ \text { Output_5 } & 99,21 & - & 99,21 \\ \text { Output_6 } & 98,20 & - & 98,20\end{array}$

DMU_11 (eficiência:1,000000)

\begin{tabular}{lrrrr} 
Variável & Atual & \multicolumn{2}{c}{ Folga } & \multicolumn{2}{c}{ Alvo } \\
Input_1 & 78,35 & & - & 78,35 \\
Input_2 & $1.355,47$ & - & $1.355,47$ \\
Input_3 & $9.497,24$ & - & $9.497,24$ \\
Output_1 & 98,53 & - & 98,53 \\
Output_2 & 98,00 & - & 98,00 \\
Output_3 & 99,75 & - & 99,75 \\
Output_4 & 97,00 & - & 97,00 \\
Output_5 & 97,00 & - & 97,00 \\
Output_6 & 100,00 & - & 100,00
\end{tabular}

DMU_12 (eficiência:1,000000)

\begin{tabular}{lrrrr} 
Variável & Atual & Folga & \multicolumn{2}{r}{ Alvo } \\
Input_1 & 77,32 & & - & 77,32 \\
Input_2 & $3.951,17$ & & - & $3.951,17$ \\
Input_3 & $8.263,15$ & - & $8.263,15$ \\
Output_1 & 98,88 & - & 98,88 \\
Output_2 & 99,00 & - & 99,00 \\
Output_3 & 99,40 & - & 99,40 \\
Output_4 & 100,00 & - & 100,00 \\
Output_5 & 99,93 & - & 99,93 \\
Output_6 & 100,00 & - & 100,00
\end{tabular}


Alvos

DMU 13 (eficiência:0,710305 )

\begin{tabular}{lrccr} 
Variável & Atual & Folga & \multicolumn{2}{c}{ Alvo } \\
Input_1 & 92,05 & - & 65,38 \\
Input_2 & $7.451,98$ & - & $5.293,18$ \\
Input_3 & $10.470,15$ & - & $7.437,00$ \\
Output_1 & 98,10 & 0,71 & 98,81 \\
Output_2 & 97,00 & 1,19 & 98,19 \\
Output_3 & 98,00 & 1,01 & 99,01 \\
Output_4 & 97,00 & 0,89 & 97,89 \\
Output_5 & 99,00 & - & 99,00 \\
Output_6 & 98,00 & 0,87 & 98,87
\end{tabular}

DMU_14 (eficiência:1,000000)

\begin{tabular}{lrrrr} 
Variável & Atual & \multicolumn{1}{c}{ Folga } & \multicolumn{2}{r}{ Alvo } \\
Input_1 & 79,33 & & - & 79,33 \\
Input_2 & $2.679,36$ & - & $2.679,36$ \\
Input_3 & $7.490,72$ & - & $7.490,72$ \\
Output_1 & 99,40 & - & 99,40 \\
Output_2 & 99,80 & - & 99,80 \\
Output_3 & 99,20 & - & 99,20 \\
Output_4 & 99,10 & - & 99,10 \\
Output_5 & 99,00 & - & 99,00 \\
Output_6 & 99,20 & - & 99,20
\end{tabular}

DMU_15 (eficiência:1,000000)

\begin{tabular}{lrrrr} 
Variável & Atual & \multicolumn{2}{c}{ Folga } & \multicolumn{2}{c}{ Alvo } \\
Input_1 & 92,72 & & - & 92,72 \\
Input_2 & $4.806,70$ & - & $4.806,70$ \\
Input_3 & $7.713,77$ & - & $7.713,77$ \\
Output_1 & 98,80 & - & 98,80 \\
Output_2 & 99,60 & - & 99,60 \\
Output_3 & 99,77 & - & 99,77 \\
Output_4 & 99,22 & - & 99,22 \\
Output_5 & 99,00 & - & 99,00 \\
Output_6 & 98,80 & - & 98,80
\end{tabular}

DMU_16 (eficiência:1,000000)

\begin{tabular}{lrrrr} 
Variável & Atual & Folga & \multicolumn{2}{r}{ Alvo } \\
Input_1 & 121,22 & & - & 121,22 \\
Input_2 & $2.706,88$ & & - & $2.706,88$ \\
Input_3 & $13.329,02$ & & - & $13.329,02$ \\
Output_1 & 99,00 & - & 99,00 \\
Output_2 & 99,00 & - & 99,00 \\
Output_3 & 100,00 & - & 100,00 \\
Output_4 & 98,00 & - & 98,00 \\
Output_5 & 98,00 & - & 98,00 \\
Output_6 & 100,00 & - & 100,00
\end{tabular}


Alvos

DMU_17 (eficiência:1,000000)

\begin{tabular}{lrrrr} 
Variável & Atual & Folga & \multicolumn{2}{c}{ Alvo } \\
Input_1 & 57,43 & & - & 57,43 \\
Input_2 & $2.226,38$ & - & $2.226,38$ \\
Input_3 & $5.117,18$ & - & $5.117,18$ \\
Output_1 & 98,20 & - & 98,20 \\
Output_2 & 97,60 & - & 97,60 \\
Output_3 & 97,60 & - & 97,60 \\
Output_4 & 98,36 & - & 98,36 \\
Output_5 & 96,90 & - & 96,90 \\
Output_6 & 98,80 & - & 98,80
\end{tabular}

DMU_18 (eficiência:1,000000)

\begin{tabular}{lrrrr} 
Variável & Atual & Folga & \multicolumn{2}{r}{ Alvo } \\
Input_1 & 83,73 & & - & 83,73 \\
Input_2 & $39.548,94$ & & - & $39.548,94$ \\
Input_3 & $10.633,38$ & - & $10.633,38$ \\
Output_1 & 98,50 & - & 98,50 \\
Output_2 & 99,00 & - & 99,00 \\
Output_3 & 99,90 & - & 99,90 \\
Output_4 & 100,00 & - & 100,00 \\
Output_5 & 99,00 & - & 99,00 \\
Output_6 & 98,70 & - & 98,70
\end{tabular}

DMU_19 (eficiência:1,000000)

\begin{tabular}{lrrrr} 
Variável & Atual & Folga & \multicolumn{2}{c}{ Alvo } \\
Input_1 & 89,67 & & - & 89,67 \\
Input_2 & $1.599,98$ & - & $1.599,98$ \\
Input_3 & $8.031,98$ & - & $8.031,98$ \\
Output_1 & 97,40 & - & 97,40 \\
Output_2 & 97,82 & - & 97,82 \\
Output_3 & 99,90 & - & 99,90 \\
Output_4 & 100,00 & - & 100,00 \\
Output_5 & 100,00 & - & 100,00 \\
Output_6 & 98,00 & - & 98,00
\end{tabular}

DMU_20 (eficiência:1,000000)

\begin{tabular}{lrlrr} 
Variável & Atual & \multicolumn{2}{c}{ Folga } & \multicolumn{2}{c}{ Alvo } \\
Input_1 & 94,98 & & - & 94,98 \\
Input_2 & 765,97 & - & 765,97 \\
Input_3 & $1.567,94$ & - & $1.567,94$ \\
Output_1 & 99,40 & - & 99,40 \\
Output_2 & 98,07 & - & 98,07 \\
Output_3 & 98,60 & - & 98,60 \\
Output_4 & 98,00 & - & 98,00 \\
Output_5 & 100,00 & - & 100,00 \\
Output_6 & 96,90 & - & 96,90
\end{tabular}


Alvos

DMU 21 (eficiência:1,000000)

\begin{tabular}{lrrrr} 
Variável & Atual & Folga & \multicolumn{2}{r}{ Alvo } \\
Input_1 & 132,76 & & - & 132,76 \\
Input_2 & $82.786,43$ & - & $82.786,43$ \\
Input_3 & $19.189,70$ & - & $19.189,70$ \\
Output_1 & 99,33 & - & 99,33 \\
Output_2 & 99,67 & - & 99,67 \\
Output_3 & 100,00 & - & 100,00 \\
Output_4 & 100,00 & - & 100,00 \\
Output_5 & 100,00 & - & 100,00 \\
Output_6 & 99,80 & - & 99,80
\end{tabular}

DMU_22 (eficiência:1,000000)

\begin{tabular}{lrrrr} 
Variável & Atual & \multicolumn{2}{c}{ Folga } & \multicolumn{2}{r}{ Alvo } \\
Input_1 & 96,53 & & - & 96,53 \\
Input_2 & $94.496,73$ & - & $94.496,73$ \\
Input_3 & $11.982,50$ & - & $11.982,50$ \\
Output_1 & 100,00 & - & 100,00 \\
Output_2 & 99,65 & - & 99,65 \\
Output_3 & 99,80 & - & 99,80 \\
Output_4 & 98,60 & - & 98,60 \\
Output_5 & 98,00 & - & 98,00 \\
Output_6 & 99,80 & - & 99,80
\end{tabular}

DMU_23 (eficiência:1,000000)

\begin{tabular}{lrrrr} 
Variável & Atual & \multicolumn{2}{c}{ Folga } & \multicolumn{2}{r}{ Alvo } \\
Input_1 & 45,02 & - & 45,02 \\
Input_2 & $7.135,81$ & - & $7.135,81$ \\
Input_3 & $6.232,35$ & - & $6.232,35$ \\
Output_1 & 98,80 & - & 98,80 \\
Output_2 & 95,10 & - & 95,10 \\
Output_3 & 99,50 & - & 99,50 \\
Output_4 & 95,50 & - & 95,50 \\
Output_5 & 95,20 & - & 95,20 \\
Output_6 & 94,50 & - & 94,50
\end{tabular}

DMU_24 (eficiência:1,000000)

\begin{tabular}{lrrrr} 
Variável & Atual & \multicolumn{2}{c}{ Folga } & \\
Input_1 & 208,00 & & - & Alvo \\
Input_2 & $5.165,69$ & & - & $5.165,69$ \\
Input_3 & 655,03 & - & 655,03 \\
Output_1 & 98,60 & - & 98,60 \\
Output_2 & 97,80 & - & 97,80 \\
Output_3 & 100,00 & - & 100,00 \\
Output_4 & 97,20 & - & 97,20 \\
Output_5 & 97,10 & - & 97,10 \\
Output_6 & 95,40 & - & 95,40
\end{tabular}


Alvos

DMU 25 (eficiência:0,535159 )

\begin{tabular}{lrrr} 
Variável & Atual & \multicolumn{2}{c}{ Folga } \\
Input_1 & 311,32 & 5,60 & 161,00 \\
Input_2 & $25.800,94$ & $5.835,99$ & $7.971,61$ \\
Input_3 & $30.443,61$ & - & $16.292,16$ \\
Output_1 & 100,00 & - & 100,00 \\
Output_2 & 97,19 & - & 97,19 \\
Output_3 & 100,00 & - & 100,00 \\
Output_4 & 98,80 & 0,58 & 99,38 \\
Output_5 & 98,00 & 0,84 & 98,84 \\
Output_6 & 98,00 & 0,46 & 98,46
\end{tabular}

DMU_26 (eficiência:1,000000)

\begin{tabular}{lrrrr} 
Variável & Atual & Folga & \multicolumn{2}{c}{ Alvo } \\
Input_1 & 84,20 & & - & 84,20 \\
Input_2 & $2.646,96$ & - & $2.646,96$ \\
Input_3 & $7.044,35$ & - & $7.044,35$ \\
Output_1 & 99,50 & - & 99,50 \\
Output_2 & 98,51 & - & 98,51 \\
Output_3 & 98,56 & - & 98,56 \\
Output_4 & 97,85 & - & 97,85 \\
Output_5 & 96,73 & - & 96,73 \\
Output_6 & 98,50 & - & 98,50
\end{tabular}

DMU_27 (eficiência:1,000000)

\begin{tabular}{lrrrr} 
Variável & Atual & \multicolumn{2}{c}{ Folga } & \multicolumn{2}{c}{ Alvo } \\
Input_1 & 89,82 & & - & 89,82 \\
Input_2 & $139.122,91$ & & - & $139.122,91$ \\
Input_3 & $52.908,92$ & - & $52.908,92$ \\
Output_1 & 99,52 & - & 99,52 \\
Output_2 & 99,50 & - & 99,50 \\
Output_3 & 99,50 & - & 99,50 \\
Output_4 & 99,00 & - & 99,00 \\
Output_5 & 99,00 & - & 99,00 \\
Output_6 & 99,50 & - & 99,50
\end{tabular}

DMU_28 (eficiência:1,000000)

\begin{tabular}{lrrrr} 
Variável & Atual & Folga & \multicolumn{2}{r}{ Alvo } \\
Input_1 & 196,30 & & - & 196,30 \\
Input_2 & $23.950,14$ & & - & $23.950,14$ \\
Input_3 & $18.148,84$ & & - & $18.148,84$ \\
Output_1 & 98,65 & - & 98,65 \\
Output_2 & 99,10 & - & 99,10 \\
Output_3 & 99,70 & - & 99,70 \\
Output_4 & 100,00 & - & 100,00 \\
Output_5 & 99,66 & - & 99,66 \\
Output_6 & 100,00 & - & 100,00
\end{tabular}


Alvos

DMU 29 (eficiência:1,000000)

\begin{tabular}{lrrrr} 
Variável & Atual & Folga & \multicolumn{2}{c}{ Alvo } \\
Input_1 & 188,44 & & - & 188,44 \\
Input_2 & $6.505,87$ & - & $6.505,87$ \\
Input_3 & $4.274,43$ & - & $4.274,43$ \\
Output_1 & 98,80 & - & 98,80 \\
Output_2 & 97,20 & - & 97,20 \\
Output_3 & 96,60 & - & 96,60 \\
Output_4 & 99,80 & - & 99,80 \\
Output_5 & 97,90 & - & 97,90 \\
Output_6 & 96,49 & - & 96,49
\end{tabular}

DMU_30 (eficiência:1,000000)

\begin{tabular}{lrrrr} 
Variável & Atual & Folga & \multicolumn{2}{r}{ Alvo } \\
Input_1 & 129,50 & & - & 129,50 \\
Input_2 & $12.593,49$ & - & $12.593,49$ \\
Input_3 & $25.564,53$ & - & $25.564,53$ \\
Output_1 & 100,00 & - & 100,00 \\
Output_2 & 99,44 & - & 99,44 \\
Output_3 & 100,00 & - & 100,00 \\
Output_4 & 98,92 & - & 98,92 \\
Output_5 & 98,00 & - & 98,00 \\
Output_6 & 98,40 & - & 98,40
\end{tabular}

DMU_31 (eficiência:0,502660)

\begin{tabular}{lrrrr} 
Variável & Atual & Folga & \multicolumn{2}{c}{ Alvo } \\
Input_1 & 159,57 & - & 80,21 \\
Input_2 & $2.554,75$ & - & $1.284,17$ \\
Input_3 & $10.227,10$ & 302,52 & $4.838,23$ \\
Output_1 & 98,00 & 1,07 & 99,07 \\
Output_2 & 97,00 & - & 97,00 \\
Output_3 & 97,00 & 1,83 & 98,83 \\
Output_4 & 96,00 & 1,72 & 97,72 \\
Output_5 & 98,00 & - & 98,00 \\
Output_6 & 98,00 & 0,65 & 98,65
\end{tabular}

DMU_32 (eficiência:1,000000)

\begin{tabular}{lrrrr} 
Variável & Atual & Folga & \multicolumn{2}{r}{ Alvo } \\
Input_1 & 190,52 & & - & 190,52 \\
Input_2 & $21.317,92$ & & - & $21.317,92$ \\
Input_3 & $16.944,09$ & & - & $16.944,09$ \\
Output_1 & 99,00 & - & 99,00 \\
Output_2 & 100,00 & - & 100,00 \\
Output_3 & 100,00 & - & 100,00 \\
Output_4 & 97,70 & - & 97,70 \\
Output_5 & 98,20 & - & 98,20 \\
Output_6 & 99,10 & - & 99,10
\end{tabular}


Alvos

DMU 33 (eficiência:1,000000)

\begin{tabular}{lrrrr} 
Variável & Atual & \multicolumn{2}{c}{ Folga } & \multicolumn{2}{c}{ Alvo } \\
Input_1 & 81,91 & & - & 81,91 \\
Input_2 & $2.070,50$ & - & $2.070,50$ \\
Input_3 & $4.553,48$ & - & $4.553,48$ \\
Output_1 & 97,57 & - & 97,57 \\
Output_2 & 99,00 & - & 99,00 \\
Output_3 & 99,88 & - & 99,88 \\
Output_4 & 97,80 & - & 97,80 \\
Output_5 & 99,33 & - & 99,33 \\
Output_6 & 100,00 & - & 100,00
\end{tabular}

DMU_34 (eficiência:0,553185 )

\begin{tabular}{|c|c|c|c|}
\hline Variável & Atual & Folga & Alvo \\
\hline Input_1 & 153,00 & - & 84,64 \\
\hline Input_2 & $77.569,98$ & $13.608,45$ & $29.302,06$ \\
\hline Input_3 & $17.806,45$ & - & $9.850,25$ \\
\hline Output_1 & 97,75 & 0,46 & 98,21 \\
\hline Output_2 & 98,20 & 0,51 & 98,71 \\
\hline Output_3 & 99,88 & - & 99,88 \\
\hline Output_4 & 100,00 & - & 100,00 \\
\hline Output_5 & 96,30 & 2,90 & 99,20 \\
\hline Output_6 & 97,02 & 1,48 & 98,50 \\
\hline
\end{tabular}

DMU_35 (eficiência:1,000000)

\begin{tabular}{lrrrr} 
Variável & Atual & Folga & \multicolumn{2}{c}{ Alvo } \\
Input_1 & 111,48 & & - & 111,48 \\
Input_2 & $29.672,30$ & - & $29.672,30$ \\
Input_3 & $8.002,50$ & - & $8.002,50$ \\
Output_1 & 99,00 & - & 99,00 \\
Output_2 & 98,77 & - & 98,77 \\
Output_3 & 100,00 & - & 100,00 \\
Output_4 & 100,00 & - & 100,00 \\
Output_5 & 100,00 & - & 100,00 \\
Output_6 & 96,80 & - & 96,80
\end{tabular}

DMU_36 (eficiência:1,000000)

\begin{tabular}{lrrrr} 
Variável & Atual & Folga & \multicolumn{2}{r}{ Alvo } \\
Input_1 & 72,91 & & - & 72,91 \\
Input_2 & $3.653,57$ & & - & $3.653,57$ \\
Input_3 & $10.332,77$ & - & $10.332,77$ \\
Output_1 & 99,12 & - & 99,12 \\
Output_2 & 98,85 & - & 98,85 \\
Output_3 & 99,54 & - & 99,54 \\
Output_4 & 96,65 & - & 96,65 \\
Output_5 & 100,00 & - & 100,00 \\
Output_6 & 99,60 & - & 99,60
\end{tabular}


Alvos

DMU 37 (eficiência:1,000000)

\begin{tabular}{lrrrr} 
Variável & Atual & Folga & \multicolumn{2}{c}{ Alvo } \\
Input_1 & 86,62 & & - & 86,62 \\
Input_2 & 924,61 & - & 924,61 \\
Input_3 & $6.839,72$ & - & $6.839,72$ \\
Output_1 & 99,68 & - & 99,68 \\
Output_2 & 95,10 & - & 95,10 \\
Output_3 & 100,00 & - & 100,00 \\
Output_4 & 97,00 & - & 97,00 \\
Output_5 & 97,20 & - & 97,20 \\
Output_6 & 100,00 & - & 100,00
\end{tabular}

DMU_38 (eficiência:0,666551)

\begin{tabular}{lrrrr} 
Variável & Atual & \multicolumn{2}{c}{ Folga } & \multicolumn{2}{c}{ Alvo } \\
Input_1 & 208,00 & 54,23 & 84,41 \\
Input_2 & $2.884,14$ & - & $1.922,43$ \\
Input_3 & $8.567,10$ & $1.050,47$ & $4.659,93$ \\
Output_1 & 97,80 & 0,75 & 98,55 \\
Output_2 & 99,00 & - & 99,00 \\
Output_3 & 98,00 & 1,37 & 99,37 \\
Output_4 & 97,10 & 1,12 & 98,22 \\
Output_5 & 97,58 & 1,82 & 99,40 \\
Output_6 & 99,00 & - & 99,00
\end{tabular}

DMU_39 (eficiência:0,573617 )

\begin{tabular}{lrrrr} 
Variável & Atual & Folga & \multicolumn{2}{c}{ Alvo } \\
Input_1 & 179,64 & - & 103,04 \\
Input_2 & $4.680,02$ & - & $2.684,54$ \\
Input_3 & $9.560,98$ & - & $5.484,34$ \\
Output_1 & 99,00 & - & 99,00 \\
Output_2 & 97,70 & - & 97,70 \\
Output_3 & 99,40 & - & 99,40 \\
Output_4 & 99,40 & - & 99,40 \\
Output_5 & 98,30 & 0,81 & 99,11 \\
Output_6 & 97,20 & 1,37 & 98,57
\end{tabular}

DMU_40 (eficiência:1,000000)

$\begin{array}{lrrrr}\text { Variável } & \text { Atual } & \text { Folga } & & \text { Alvo } \\ \text { Input_1 } & 204,13 & & - & 204,13 \\ \text { Input_2 } & 1.644,25 & & - & 1.644,25 \\ \text { Input_3 } & 3.598,29 & & - & 3.598,29 \\ \text { Output_1 } & 100,00 & - & 100,00 \\ \text { Output_2 } & 94,11 & - & 94,11 \\ \text { Output_3 } & 100,00 & - & 100,00 \\ \text { Output_4 } & 100,00 & - & 100,00 \\ \text { Output_5 } & 100,00 & - & 100,00 \\ \text { Output_6 } & 98,55 & - & 98,55\end{array}$


DMU_41 (eficiência:1,000000)

\begin{tabular}{lrrrr} 
Variável & Atual & Folga & \multicolumn{2}{c}{ Alvo } \\
Input_1 & 122,05 & - & 122,05 \\
Input_2 & $5.355,91$ & - & $5.355,91$ \\
Input_3 & $9.808,63$ & - & $9.808,63$ \\
Output_1 & 99,60 & - & 99,60 \\
Output_2 & 99,80 & - & 99,80 \\
Output_3 & 99,00 & - & 99,00 \\
Output_4 & 99,00 & - & 99,00 \\
Output_5 & 99,10 & - & 99,10 \\
Output_6 & 98,90 & - & 98,90 \\
& & & \\
DMU_42 & (eficiência:1,000000 $)$ & & \\
& & & \\
Variável & Atual & Folga & & Alvo \\
Input_1 & 155,08 & - & 155,08 \\
Input_2 & $4.214,54$ & - & $4.214,54$ \\
Input_3 & $27.321,09$ & - & $27.321,09$ \\
Output_1 & 99,00 & - & 99,00 \\
Output_2 & 99,77 & - & 99,77 \\
Output_3 & 99,79 & - & 99,79 \\
Output_4 & 98,22 & - & 98,22 \\
Output_5 & 98,90 & - & 98,90 \\
Output_6 & 99,00 & - & 99,00
\end{tabular}




\section{ANEXOS}

ANEXO A - Lei $n^{\circ} 10.741$ de $1^{\circ}$ de outubro de 2003. 


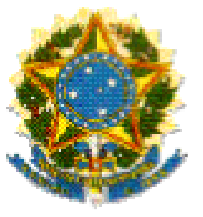

\section{Presidência da República Casa Civil Subchefia para Assuntos Jurídicos}

\section{LEI N ${ }^{\circ} 10.741$, DE $1^{\circ}$ DE OUTUBRO DE 2003.}

Dispõe sobre o Estatuto do Idoso e dá outras providências.

O PRESIDENTE DA REPÚBLICA Faço saber que o Congresso Nacional decreta e eu sanciono a seguinte Lei:

\section{TÍTULO I}

\section{Disposições Preliminares}

Art. $1^{\circ}$ É instituído o Estatuto do Idoso, destinado a regular os direitos assegurados às pessoas com idade igual ou superior a 60 (sessenta) anos.

Art. $2^{\circ} \mathrm{O}$ idoso goza de todos os direitos fundamentais inerentes à pessoa humana, sem prejuízo da proteção integral de que trata esta Lei, assegurando-se-Ihe, por lei ou por outros meios, todas as oportunidades e facilidades, para preservação de sua saúde física e mental e seu aperfeiçoamento moral, intelectual, espiritual e social, em condições de liberdade e dignidade.

Art. $3^{\circ}$ É obrigação da família, da comunidade, da sociedade e do Poder Público assegurar ao idoso, com absoluta prioridade, a efetivação do direito à vida, à saúde, à alimentação, à educação, à cultura, ao esporte, ao lazer, ao trabalho, à cidadania, à liberdade, à dignidade, ao respeito e à convivência familiar e comunitária.

Parágrafo único. A garantia de prioridade compreende:

I - atendimento preferencial imediato e individualizado junto aos órgãos públicos e privados prestadores de serviços à população;

II - preferência na formulação e na execução de políticas sociais públicas específicas; idoso;

III - destinação privilegiada de recursos públicos nas áreas relacionadas com a proteção ao

IV - viabilização de formas alternativas de participação, ocupação e convívio do idoso com as demais gerações;

V - priorização do atendimento do idoso por sua própria família, em detrimento do atendimento asilar, exceto dos que não a possuam ou careçam de condições de manutenção da própria sobrevivência;

$\mathrm{VI}$ - capacitação e reciclagem dos recursos humanos nas áreas de geriatria e gerontologia e na prestação de serviços aos idosos;

VII - estabelecimento de mecanismos que favoreçam a divulgação de informações de caráter educativo sobre os aspectos biopsicossociais de envelhecimento; 
VIII - garantia de acesso à rede de serviços de saúde e de assistência social locais.

Art. $4^{\circ}$ Nenhum idoso será objeto de qualquer tipo de negligência, discriminação, violência, crueldade ou opressão, e todo atentado aos seus direitos, por ação ou omissão, será punido na forma da lei.

$\S 1^{0}$ É dever de todos prevenir a ameaça ou violação aos direitos do idoso.

$\S 2^{\circ}$ As obrigações previstas nesta Lei não excluem da prevenção outras decorrentes dos princípios por ela adotados.

Art. $5^{\circ} \mathrm{A}$ inobservância das normas de prevenção importará em responsabilidade à pessoa física ou jurídica nos termos da lei.

Art. $6^{\circ}$ Todo cidadão tem o dever de comunicar à autoridade competente qualquer forma de violação a esta Lei que tenha testemunhado ou de que tenha conhecimento.

Art. $7^{\circ}$ Os Conselhos Nacional, Estaduais, do Distrito Federal e Municipais do Idoso, previstos na Lei $n^{\circ} 8.842$, de 4 de janeiro de 1994, zelarão pelo cumprimento dos direitos do idoso, definidos nesta Lei.

\section{TÍTULO ॥}

Dos Direitos Fundamentais

\section{CAPÍTULO I}

\section{Do Direito à Vida}

Art. $8^{\circ} \mathrm{O}$ envelhecimento é um direito personalíssimo e a sua proteção um direito social, nos termos desta Lei e da legislação vigente.

Art. $9^{\circ}$ É obrigação do Estado, garantir à pessoa idosa a proteção à vida e à saúde, mediante efetivação de políticas sociais públicas que permitam um envelhecimento saudável e em condições de dignidade.

\section{CAPÍTULO II}

\section{Do Direito à Liberdade, ao Respeito e à Dignidade}

Art. 10. É obrigação do Estado e da sociedade, assegurar à pessoa idosa a liberdade, o respeito e a dignidade, como pessoa humana e sujeito de direitos civis, políticos, individuais e sociais, garantidos na Constituição e nas leis.

$\S 1^{\circ} \mathrm{O}$ direito à liberdade compreende, entre outros, os seguintes aspectos:

I - faculdade de ir, vir e estar nos logradouros públicos e espaços comunitários, ressalvadas as restrições legais;

II - opinião e expressão;

III - crença e culto religioso;

IV - prática de esportes e de diversões;

V - participação na vida familiar e comunitária; 
VI - participação na vida política, na forma da lei;

VII - faculdade de buscar refúgio, auxílio e orientação.

$\S 2^{\circ} \mathrm{O}$ direito ao respeito consiste na inviolabilidade da integridade física, psíquica e moral, abrangendo a preservação da imagem, da identidade, da autonomia, de valores, idéias e crenças, dos espaços e dos objetos pessoais.

$\S 3^{\circ}$ É dever de todos zelar pela dignidade do idoso, colocando-o a salvo de qualquer tratamento desumano, violento, aterrorizante, vexatório ou constrangedor.

\section{CAPÍTULO III}

\section{Dos Alimentos}

Art. 11. Os alimentos serão prestados ao idoso na forma da lei civil.

Art. 12. A obrigação alimentar é solidária, podendo o idoso optar entre os prestadores.

Art. 13. As transações relativas a alimentos poderão ser celebradas perante o Promotor de Justiça, que as referendará, e passarão a ter efeito de título executivo extrajudicial nos termos da lei processual civil.

Art. 14. Se o idoso ou seus familiares não possuírem condições econômicas de prover o seu sustento, impõe-se ao Poder Público esse provimento, no âmbito da assistência social.

\section{CAPÍTULO IV}

\section{Do Direito à Saúde}

Art. 15. É assegurada a atenção integral à saúde do idoso, por intermédio do Sistema Único de Saúde - SUS, garantindo-lhe o acesso universal e igualitário, em conjunto articulado e contínuo das ações e serviços, para a prevenção, promoção, proteção e recuperação da saúde, incluindo a atenção especial às doenças que afetam preferencialmente os idosos.

$\S 1^{\circ}$ A prevenção e a manutenção da saúde do idoso serão efetivadas por meio de:

I - cadastramento da população idosa em base territorial;

II - atendimento geriátrico e gerontológico em ambulatórios;

III - unidades geriátricas de referência, com pessoal especializado nas áreas de geriatria e gerontologia social;

IV - atendimento domiciliar, incluindo a internação, para a população que dele necessitar e esteja impossibilitada de se locomover, inclusive para idosos abrigados e acolhidos por instituições públicas, filantrópicas ou sem fins lucrativos e eventualmente conveniadas com o Poder Público, nos meios urbano e rural;

V - reabilitação orientada pela geriatria e gerontologia, para redução das seqüelas decorrentes do agravo da saúde.

$\S 2^{\circ}$ Incumbe ao Poder Público fornecer aos idosos, gratuitamente, medicamentos, especialmente os de uso continuado, assim como próteses, órteses e outros recursos relativos ao tratamento, habilitação ou reabilitação. 
$\S 3^{\circ}$ É vedada a discriminação do idoso nos planos de saúde pela cobrança de valores diferenciados em razão da idade.

$\S 4^{\circ}$ Os idosos portadores de deficiência ou com limitação incapacitante terão atendimento especializado, nos termos da lei.

Art. 16. Ao idoso internado ou em observação é assegurado o direito a acompanhante, devendo o órgão de saúde proporcionar as condições adequadas para a sua permanência em tempo integral, segundo o critério médico.

Parágrafo único. Caberá ao profissional de saúde responsável pelo tratamento conceder autorização para o acompanhamento do idoso ou, no caso de impossibilidade, justificá-la por escrito.

Art. 17. Ao idoso que esteja no domínio de suas faculdades mentais é assegurado o direito de optar pelo tratamento de saúde que lhe for reputado mais favorável.

Parágrafo único. Não estando o idoso em condições de proceder à opção, esta será feita:

I - pelo curador, quando o idoso for interditado;

II - pelos familiares, quando o idoso não tiver curador ou este não puder ser contactado em tempo hábil;

III - pelo médico, quando ocorrer iminente risco de vida e não houver tempo hábil para consulta a curador ou familiar;

IV - pelo próprio médico, quando não houver curador ou familiar conhecido, caso em que deverá comunicar o fato ao Ministério Público.

Art. 18. As instituições de saúde devem atender aos critérios mínimos para o atendimento às necessidades do idoso, promovendo o treinamento e a capacitação dos profissionais, assim como orientação a cuidadores familiares e grupos de auto-ajuda.

Art. 19. Os casos de suspeita ou confirmação de maus-tratos contra idoso serão obrigatoriamente comunicados pelos profissionais de saúde a quaisquer dos seguintes órgãos:

I - autoridade policial;

II - Ministério Público;

III - Conselho Municipal do Idoso;

IV - Conselho Estadual do Idoso;

V - Conselho Nacional do Idoso.

\section{CAPÍTULO V}

Da Educação, Cultura, Esporte e Lazer

Art. 20. O idoso tem direito a educação, cultura, esporte, lazer, diversões, espetáculos, produtos e serviços que respeitem sua peculiar condição de idade.

Art. 21. O Poder Público criará oportunidades de acesso do idoso à educação, adequando currículos, metodologias e material didático aos programas educacionais a ele destinados. 
$\S 1^{\circ}$ Os cursos especiais para idosos incluirão conteúdo relativo às técnicas de comunicação, computação e demais avanços tecnológicos, para sua integração à vida moderna.

$\S 2^{\circ}$ Os idosos participarão das comemorações de caráter cívico ou cultural, para transmissão de conhecimentos e vivências às demais gerações, no sentido da preservação da memória e da identidade culturais.

Art. 22. Nos currículos mínimos dos diversos níveis de ensino formal serão inseridos conteúdos voltados ao processo de envelhecimento, ao respeito e à valorização do idoso, de forma a eliminar o preconceito e a produzir conhecimentos sobre a matéria.

Art. 23. A participação dos idosos em atividades culturais e de lazer será proporcionada mediante descontos de pelo menos $50 \%$ (cinqüenta por cento) nos ingressos para eventos artísticos, culturais, esportivos e de lazer, bem como o acesso preferencial aos respectivos locais.

Art. 24. Os meios de comunicação manterão espaços ou horários especiais voltados aos idosos, com finalidade informativa, educativa, artística e cultural, e ao público sobre o processo de envelhecimento.

Art. 25. O Poder Público apoiará a criação de universidade aberta para as pessoas idosas e incentivará a publicação de livros e periódicos, de conteúdo e padrão editorial adequados ao idoso, que facilitem a leitura, considerada a natural redução da capacidade visual.

\section{CAPÍTULO VI}

\section{Da Profissionalização e do Trabalho}

Art. 26. O idoso tem direito ao exercício de atividade profissional, respeitadas suas condições físicas, intelectuais e psíquicas.

Art. 27. Na admissão do idoso em qualquer trabalho ou emprego, é vedada a discriminação e a fixação de limite máximo de idade, inclusive para concursos, ressalvados os casos em que a natureza do cargo o exigir.

Parágrafo único. O primeiro critério de desempate em concurso público será a idade, dando-se preferência ao de idade mais elevada.

Art. 28. O Poder Público criará e estimulará programas de:

I - profissionalização especializada para os idosos, aproveitando seus potenciais e habilidades para atividades regulares e remuneradas;

II - preparação dos trabalhadores para a aposentadoria, com antecedência mínima de 1 (um) ano, por meio de estímulo a novos projetos sociais, conforme seus interesses, e de esclarecimento sobre os direitos sociais e de cidadania;

III - estímulo às empresas privadas para admissão de idosos ao trabalho.

\section{CAPÍTULO VII}

\section{Da Previdência Social}

Art. 29. Os benefícios de aposentadoria e pensão do Regime Geral da Previdência Social observarão, na sua concessão, critérios de cálculo que preservem o valor real dos salários sobre os quais incidiram contribuição, nos termos da legislação vigente. 
Parágrafo único. Os valores dos benefícios em manutenção serão reajustados na mesma data de reajuste do salário-mínimo, pro rata, de acordo com suas respectivas datas de início ou do seu último reajustamento, com base em percentual definido em regulamento, observados os critérios estabelecidos pela Lei $\mathrm{n}^{\circ} 8.213$, de 24 de julho de 1991.

Art. 30. A perda da condição de segurado não será considerada para a concessão da aposentadoria por idade, desde que a pessoa conte com, no mínimo, o tempo de contribuição correspondente ao exigido para efeito de carência na data de requerimento do benefício.

Parágrafo único. O cálculo do valor do benefício previsto no caput observará o disposto no caput e $\S 2^{\circ}$ do art. $3^{\circ}$ da Lei $n^{\circ} 9.876$, de 26 de novembro de 1999 , ou, não havendo salários-decontribuição recolhidos a partir da competência de julho de 1994, o disposto no art. 35 da Lei $n^{\circ}$ 8.213, de 1991.

Art. 31. O pagamento de parcelas relativas a benefícios, efetuado com atraso por responsabilidade da Previdência Social, será atualizado pelo mesmo índice utilizado para os reajustamentos dos benefícios do Regime Geral de Previdência Social, verificado no período compreendido entre o mês que deveria ter sido pago e o mês do efetivo pagamento.

Art. 32. O Dia Mundial do Trabalho, $1^{0}$ de Maio, é a data-base dos aposentados e pensionistas.

\section{CAPÍTULO VIII}

\section{Da Assistência Social}

Art. 33. A assistência social aos idosos será prestada, de forma articulada, conforme os princípios e diretrizes previstos na Lei Orgânica da Assistência Social, na Política Nacional do Idoso, no Sistema Único de Saúde e demais normas pertinentes.

Art. 34. Aos idosos, a partir de 65 (sessenta e cinco) anos, que não possuam meios para prover sua subsistência, nem de tê-la provida por sua família, é assegurado o benefício mensal de 1 (um) salário-mínimo, nos termos da Lei Orgânica da Assistência Social - Loas.

Parágrafo único. O benefício já concedido a qualquer membro da família nos termos do caput não será computado para os fins do cálculo da renda familiar per capita a que se refere a Loas.

Art. 35. Todas as entidades de longa permanência, ou casa-lar, são obrigadas a firmar contrato de prestação de serviços com a pessoa idosa abrigada.

$\S 1^{\circ}$ No caso de entidades filantrópicas, ou casa-lar, é facultada a cobrança de participação do idoso no custeio da entidade.

$\S 2^{\circ}$ O Conselho Municipal do Idoso ou o Conselho Municipal da Assistência Social estabelecerá a forma de participação prevista no $\S 1^{\circ}$, que não poderá exceder a $70 \%$ (setenta por cento) de qualquer benefício previdenciário ou de assistência social percebido pelo idoso.

$\S 3^{\circ}$ Se a pessoa idosa for incapaz, caberá a seu representante legal firmar o contrato a que se refere o caput deste artigo.

Art. 36. O acolhimento de idosos em situação de risco social, por adulto ou núcleo familiar, caracteriza a dependência econômica, para os efeitos legais.

\section{CAPÍTULO IX}

\section{Da Habitação}


Art. 37. O idoso tem direito a moradia digna, no seio da família natural ou substituta, ou desacompanhado de seus familiares, quando assim o desejar, ou, ainda, em instituição pública ou privada.

$\S 1^{\circ} \mathrm{A}$ assistência integral na modalidade de entidade de longa permanência será prestada quando verificada inexistência de grupo familiar, casa-lar, abandono ou carência de recursos financeiros próprios ou da família.

$\S 2^{0}$ Toda instituição dedicada ao atendimento ao idoso fica obrigada a manter identificação externa visível, sob pena de interdição, além de atender toda a legislação pertinente.

$\S 3^{\circ}$ As instituições que abrigarem idosos são obrigadas a manter padrões de habitação compatíveis com as necessidades deles, bem como provê-los com alimentação regular e higiene indispensáveis às normas sanitárias e com estas condizentes, sob as penas da lei.

Art. 38. Nos programas habitacionais, públicos ou subsidiados com recursos públicos, o idoso goza de prioridade na aquisição de imóvel para moradia própria, observado o seguinte:

I - reserva de 3\% (três por cento) das unidades residenciais para atendimento aos idosos;

II - implantação de equipamentos urbanos comunitários voltados ao idoso; idoso;

III - eliminação de barreiras arquitetônicas e urbanísticas, para garantia de acessibilidade ao

IV - critérios de financiamento compatíveis com os rendimentos de aposentadoria e pensão.

\section{CAPÍTULO X}

\section{Do Transporte}

Art. 39. Aos maiores de 65 (sessenta e cinco) anos fica assegurada a gratuidade dos transportes coletivos públicos urbanos e semi-urbanos, exceto nos serviços seletivos e especiais, quando prestados paralelamente aos serviços regulares.

$\S 1^{\circ}$ Para ter acesso à gratuidade, basta que o idoso apresente qualquer documento pessoal que faça prova de sua idade.

$\S 2^{\circ}$ Nos veículos de transporte coletivo de que trata este artigo, serão reservados $10 \%$ (dez por cento) dos assentos para os idosos, devidamente identificados com a placa de reservado preferencialmente para idosos.

$\S 3^{0}$ No caso das pessoas compreendidas na faixa etária entre 60 (sessenta) e 65 (sessenta e cinco) anos, ficará a critério da legislação local dispor sobre as condições para exercício da gratuidade nos meios de transporte previstos no caput deste artigo.

Art. 40. No sistema de transporte coletivo interestadual observar-se-á, nos termos da legislação específica: (Regulamento)

I - a reserva de 2 (duas) vagas gratuitas por veículo para idosos com renda igual ou inferior a 2 (dois) salários-mínimos;

II - desconto de 50\% (cinqüenta por cento), no mínimo, no valor das passagens, para os idosos que excederem as vagas gratuitas, com renda igual ou inferior a 2 (dois) salários-mínimos. 
Parágrafo único. Caberá aos órgãos competentes definir os mecanismos e os critérios para o exercício dos direitos previstos nos incisos I e II.

Art. 41. É assegurada a reserva, para os idosos, nos termos da lei local, de $5 \%$ (cinco por cento) das vagas nos estacionamentos públicos e privados, as quais deverão ser posicionadas de forma a garantir a melhor comodidade ao idoso.

Art. 42. É assegurada a prioridade do idoso no embarque no sistema de transporte coletivo.

TÍTULO III

Das Medidas de Proteção

CAPÍTULO I

Das Disposições Gerais

Art. 43. As medidas de proteção ao idoso são aplicáveis sempre que os direitos reconhecidos nesta Lei forem ameaçados ou violados:

I - por ação ou omissão da sociedade ou do Estado;

II - por falta, omissão ou abuso da família, curador ou entidade de atendimento;

III - em razão de sua condição pessoal.

\section{CAPÍTULO II}

\section{Das Medidas Específicas de Proteção}

Art. 44. As medidas de proteção ao idoso previstas nesta Lei poderão ser aplicadas, isolada ou cumulativamente, e levarão em conta os fins sociais a que se destinam e o fortalecimento dos vínculos familiares e comunitários.

Art. 45. Verificada qualquer das hipóteses previstas no art. 43, o Ministério Público ou o Poder Judiciário, a requerimento daquele, poderá determinar, dentre outras, as seguintes medidas:

I - encaminhamento à família ou curador, mediante termo de responsabilidade;

II - orientação, apoio e acompanhamento temporários;

III - requisição para tratamento de sua saúde, em regime ambulatorial, hospitalar ou domiciliar;

IV - inclusão em programa oficial ou comunitário de auxílio, orientação e tratamento a usuários dependentes de drogas lícitas ou ilícitas, ao próprio idoso ou à pessoa de sua convivência que the cause perturbação;

V - abrigo em entidade;

VI - abrigo temporário.

\section{TÍTULO IV}

Da Política de Atendimento ao Idoso 


\section{CAPÍTULO I}

\section{Disposições Gerais}

Art. 46. A política de atendimento ao idoso far-se-á por meio do conjunto articulado de ações governamentais e não-governamentais da União, dos Estados, do Distrito Federal e dos Municípios.

Art. 47. São linhas de ação da política de atendimento:

I - políticas sociais básicas, previstas na Lei $\mathrm{n}^{\circ} 8.842$, de 4 de janeiro de 1994;

II - políticas e programas de assistência social, em caráter supletivo, para aqueles que necessitarem;

III - serviços especiais de prevenção e atendimento às vítimas de negligência, maus-tratos, exploração, abuso, crueldade e opressão;

IV - serviço de identificação e localização de parentes ou responsáveis por idosos abandonados em hospitais e instituições de longa permanência;

V - proteção jurídico-social por entidades de defesa dos direitos dos idosos;

VI - mobilização da opinião pública no sentido da participação dos diversos segmentos da sociedade no atendimento do idoso.

\section{CAPÍTULO II}

\section{Das Entidades de Atendimento ao Idoso}

Art. 48. As entidades de atendimento são responsáveis pela manutenção das próprias unidades, observadas as normas de planejamento e execução emanadas do órgão competente da Política Nacional do Idoso, conforme a Lei $\mathrm{n}^{\circ} 8.842$, de 1994.

Parágrafo único. As entidades governamentais e não-governamentais de assistência ao idoso ficam sujeitas à inscrição de seus programas, junto ao órgão competente da Vigilância Sanitária e Conselho Municipal da Pessoa Idosa, e em sua falta, junto ao Conselho Estadual ou Nacional da Pessoa Idosa, especificando os regimes de atendimento, observados os seguintes requisitos:

I - oferecer instalações físicas em condições adequadas de habitabilidade, higiene, salubridade e segurança; Lei;

II - apresentar objetivos estatutários e plano de trabalho compatíveis com os princípios desta

III - estar regularmente constituída;

IV - demonstrar a idoneidade de seus dirigentes.

Art. 49. As entidades que desenvolvam programas de institucionalização de longa permanência adotarão os seguintes princípios:

I - preservação dos vínculos familiares;

II - atendimento personalizado e em pequenos grupos;

III - manutenção do idoso na mesma instituição, salvo em caso de força maior; 
IV - participação do idoso nas atividades comunitárias, de caráter interno e externo;

V - observância dos direitos e garantias dos idosos;

VI - preservação da identidade do idoso e oferecimento de ambiente de respeito e dignidade.

Parágrafo único. O dirigente de instituição prestadora de atendimento ao idoso responderá civil e criminalmente pelos atos que praticar em detrimento do idoso, sem prejuízo das sanções administrativas.

Art. 50. Constituem obrigações das entidades de atendimento:

I - celebrar contrato escrito de prestação de serviço com o idoso, especificando o tipo de atendimento, as obrigações da entidade e prestações decorrentes do contrato, com os respectivos preços, se for o caso;

II - observar os direitos e as garantias de que são titulares os idosos;

III - fornecer vestuário adequado, se for pública, e alimentação suficiente;

IV - oferecer instalações físicas em condições adequadas de habitabilidade;

$\mathrm{V}$ - oferecer atendimento personalizado;

$\mathrm{VI}$ - diligenciar no sentido da preservação dos vínculos familiares;

VII - oferecer acomodações apropriadas para recebimento de visitas;

VIII - proporcionar cuidados à saúde, conforme a necessidade do idoso;

IX - promover atividades educacionais, esportivas, culturais e de lazer;

$\mathrm{X}$ - propiciar assistência religiosa àqueles que desejarem, de acordo com suas crenças;

XI - proceder a estudo social e pessoal de cada caso;

XII - comunicar à autoridade competente de saúde toda ocorrência de idoso portador de doenças infecto-contagiosas;

XIII - providenciar ou solicitar que o Ministério Público requisite os documentos necessários ao exercício da cidadania àqueles que não os tiverem, na forma da lei;

XIV - fornecer comprovante de depósito dos bens móveis que receberem dos idosos;

$X V$ - manter arquivo de anotações onde constem data e circunstâncias do atendimento, nome do idoso, responsável, parentes, endereços, cidade, relação de seus pertences, bem como o valor de contribuições, e suas alterações, se houver, e demais dados que possibilitem sua identificação e a individualização do atendimento;

$\mathrm{XVI}$ - comunicar ao Ministério Público, para as providências cabíveis, a situação de abandono moral ou material por parte dos familiares;

XVII - manter no quadro de pessoal profissionais com formação específica.

Art. 51. As instituições filantrópicas ou sem fins lucrativos prestadoras de serviço ao idoso terão direito à assistência judiciária gratuita. 


\section{CAPÍTULO III}

Da Fiscalização das Entidades de Atendimento

Art. 52. As entidades governamentais e não-governamentais de atendimento ao idoso serão fiscalizadas pelos Conselhos do Idoso, Ministério Público, Vigilância Sanitária e outros previstos em lei.

Art. 53. $O$ art. $7^{\circ}$ da Lei $n^{0} 8.842$, de 1994, passa a vigorar com a seguinte redação:

"Art. $7^{\circ}$ Compete aos Conselhos de que trata o art. $6^{\circ}$ desta Lei a supervisão, o acompanhamento, a fiscalização e a avaliação da política nacional do idoso, no âmbito das respectivas instâncias políticoadministrativas." (NR)

Art. 54. Será dada publicidade das prestações de contas dos recursos públicos e privados recebidos pelas entidades de atendimento.

Art. 55. As entidades de atendimento que descumprirem as determinações desta Lei ficarão sujeitas, sem prejuízo da responsabilidade civil e criminal de seus dirigentes ou prepostos, às seguintes penalidades, observado o devido processo legal:

I - as entidades governamentais:

a) advertência;

b) afastamento provisório de seus dirigentes;

c) afastamento definitivo de seus dirigentes;

d) fechamento de unidade ou interdição de programa;

II - as entidades não-governamentais:

a) advertência;

b) multa;

c) suspensão parcial ou total do repasse de verbas públicas;

d) interdição de unidade ou suspensão de programa;

e) proibição de atendimento a idosos a bem do interesse público.

$\S 1^{\circ}$ Havendo danos aos idosos abrigados ou qualquer tipo de fraude em relação ao programa, caberá o afastamento provisório dos dirigentes ou a interdição da unidade e a suspensão do programa.

$\S 2^{\circ}$ A suspensão parcial ou total do repasse de verbas públicas ocorrerá quando verificada a má aplicação ou desvio de finalidade dos recursos.

$\S 3^{\circ} \mathrm{Na}$ ocorrência de infração por entidade de atendimento, que coloque em risco os direitos assegurados nesta Lei, será o fato comunicado ao Ministério Público, para as providências cabíveis, inclusive para promover a suspensão das atividades ou dissolução da entidade, com a proibição de atendimento a idosos a bem do interesse público, sem prejuízo das providências a serem tomadas pela Vigilância Sanitária. 
$\S 4^{\circ} \mathrm{Na}$ aplicação das penalidades, serão consideradas a natureza e a gravidade da infração cometida, os danos que dela provierem para o idoso, as circunstâncias agravantes ou atenuantes e os antecedentes da entidade.

\section{CAPÍTULO IV}

Das Infrações Administrativas

Art. 56. Deixar a entidade de atendimento de cumprir as determinações do art. 50 desta Lei:

Pena - multa de $R \$ 500,00$ (quinhentos reais) a $R \$ 3.000,00$ (três mil reais), se o fato não for caracterizado como crime, podendo haver a interdição do estabelecimento até que sejam cumpridas as exigências legais.

Parágrafo único. No caso de interdição do estabelecimento de longa permanência, os idosos abrigados serão transferidos para outra instituição, a expensas do estabelecimento interditado, enquanto durar a interdição.

Art. 57. Deixar o profissional de saúde ou o responsável por estabelecimento de saúde ou instituição de longa permanência de comunicar à autoridade competente os casos de crimes contra idoso de que tiver conhecimento:

Pena - multa de $R \$ 500,00$ (quinhentos reais) a $R \$ 3.000,00$ (três mil reais), aplicada em dobro no caso de reincidência. idoso:

Art. 58. Deixar de cumprir as determinações desta Lei sobre a prioridade no atendimento ao

Pena - multa de $R \$ 500,00$ (quinhentos reais) a $R \$ 1.000,00$ (um mil reais) e multa civil a ser estipulada pelo juiz, conforme o dano sofrido pelo idoso.

\section{CAPÍTULO V}

\section{Da Apuração Administrativa de Infração às}

Normas de Proteção ao Idoso

Art. 59. Os valores monetários expressos no Capítulo IV serão atualizados anualmente, na forma da lei.

Art. 60. O procedimento para a imposição de penalidade administrativa por infração às normas de proteção ao idoso terá início com requisição do Ministério Público ou auto de infração elaborado por servidor efetivo e assinado, se possível, por duas testemunhas.

$\S 1^{\circ}$ No procedimento iniciado com o auto de infração poderão ser usadas fórmulas impressas, especificando-se a natureza e as circunstâncias da infração.

$\S 2^{\circ}$ Sempre que possível, à verificação da infração seguir-se-á a lavratura do auto, ou este será lavrado dentro de 24 (vinte e quatro) horas, por motivo justificado.

Art. 61. O autuado terá prazo de 10 (dez) dias para a apresentação da defesa, contado da data da intimação, que será feita:

I - pelo autuante, no instrumento de autuação, quando for lavrado na presença do infrator;

II - por via postal, com aviso de recebimento. 
Art. 62. Havendo risco para a vida ou à saúde do idoso, a autoridade competente aplicará à entidade de atendimento as sanções regulamentares, sem prejuízo da iniciativa e das providências que vierem a ser adotadas pelo Ministério Público ou pelas demais instituições legitimadas para a fiscalização.

Art. 63. Nos casos em que não houver risco para a vida ou a saúde da pessoa idosa abrigada, a autoridade competente aplicará à entidade de atendimento as sanções regulamentares, sem prejuízo da iniciativa e das providências que vierem a ser adotadas pelo Ministério Público ou pelas demais instituições legitimadas para a fiscalização.

\section{CAPÍTULO VI}

Da Apuração Judicial de Irregularidades em Entidade de Atendimento

Art. 64. Aplicam-se, subsidiariamente, ao procedimento administrativo de que trata este Capítulo as disposições das Leis $\mathrm{n}^{\text {os }} 6.437$, de 20 de agosto de 1977, e 9.784 , de 29 de janeiro de 1999.

Art. 65. O procedimento de apuração de irregularidade em entidade governamental e nãogovernamental de atendimento ao idoso terá início mediante petição fundamentada de pessoa interessada ou iniciativa do Ministério Público.

Art. 66. Havendo motivo grave, poderá a autoridade judiciária, ouvido o Ministério Público, decretar liminarmente o afastamento provisório do dirigente da entidade ou outras medidas que julgar adequadas, para evitar lesão aos direitos do idoso, mediante decisão fundamentada.

Art. 67. O dirigente da entidade será citado para, no prazo de 10 (dez) dias, oferecer resposta escrita, podendo juntar documentos e indicar as provas a produzir.

Art. 68. Apresentada a defesa, o juiz procederá na conformidade do art. 69 ou, se necessário, designará audiência de instrução e julgamento, deliberando sobre a necessidade de produção de outras provas.

$\S 1^{\circ}$ Salvo manifestação em audiência, as partes e o Ministério Público terão 5 (cinco) dias para oferecer alegações finais, decidindo a autoridade judiciária em igual prazo.

$\S 2^{\circ}$ Em se tratando de afastamento provisório ou definitivo de dirigente de entidade governamental, a autoridade judiciária oficiará a autoridade administrativa imediatamente superior ao afastado, fixando-lhe prazo de 24 (vinte e quatro) horas para proceder à substituição.

$\S 3^{\circ}$ Antes de aplicar qualquer das medidas, a autoridade judiciária poderá fixar prazo para a remoção das irregularidades verificadas. Satisfeitas as exigências, o processo será extinto, sem julgamento do mérito.

$\S 4^{\circ}$ A multa e a advertência serão impostas ao dirigente da entidade ou ao responsável pelo programa de atendimento.

\section{TÍTULO V}

Do Acesso à Justiça

CAPÍTULO I

\section{Disposições Gerais}

Art. 69. Aplica-se, subsidiariamente, às disposições deste Capítulo, o procedimento sumário previsto no Código de Processo Civil, naquilo que não contrarie os prazos previstos nesta Lei. 
Art. 70. O Poder Público poderá criar varas especializadas e exclusivas do idoso.

Art. 71. É assegurada prioridade na tramitação dos processos e procedimentos e na execução dos atos e diligências judiciais em que figure como parte ou interveniente pessoa com idade igual ou superior a 60 (sessenta) anos, em qualquer instância.

$\S 1^{\circ} \mathrm{O}$ interessado na obtenção da prioridade a que alude este artigo, fazendo prova de sua idade, requererá o benefício à autoridade judiciária competente para decidir o feito, que determinará as providências a serem cumpridas, anotando-se essa circunstância em local visível nos autos do processo.

$\S 2^{\circ}$ A prioridade não cessará com a morte do beneficiado, estendendo-se em favor do cônjuge supérstite, companheiro ou companheira, com união estável, maior de 60 (sessenta) anos.

$\S 3^{\circ} \mathrm{A}$ prioridade se estende aos processos e procedimentos na Administração Pública, empresas prestadoras de serviços públicos e instituições financeiras, ao atendimento preferencial junto à Defensoria Publica da União, dos Estados e do Distrito Federal em relação aos Serviços de Assistência Judiciária.

$\S 4^{\circ}$ Para o atendimento prioritário será garantido ao idoso o fácil acesso aos assentos e caixas, identificados com a destinação a idosos em local visível e caracteres legíveis.

\section{CAPÍTULO II}

Do Ministério Público

\section{Art. 72. (VETADO)}

Art. 73. As funções do Ministério Público, previstas nesta Lei, serão exercidas nos termos da respectiva Lei Orgânica.

Art. 74. Compete ao Ministério Público:

I - instaurar o inquérito civil e a ação civil pública para a proteção dos direitos e interesses difusos ou coletivos, individuais indisponíveis e individuais homogêneos do idoso;

II - promover e acompanhar as ações de alimentos, de interdição total ou parcial, de designação de curador especial, em circunstâncias que justifiquem a medida e oficiar em todos os feitos em que se discutam os direitos de idosos em condições de risco;

III - atuar como substituto processual do idoso em situação de risco, conforme o disposto no art. 43 desta Lei;

IV - promover a revogação de instrumento procuratório do idoso, nas hipóteses previstas no art. 43 desta Lei, quando necessário ou o interesse público justificar;

V - instaurar procedimento administrativo e, para instruí-lo:

a) expedir notificações, colher depoimentos ou esclarecimentos e, em caso de não comparecimento injustificado da pessoa notificada, requisitar condução coercitiva, inclusive pela Polícia Civil ou Militar;

b) requisitar informações, exames, perícias e documentos de autoridades municipais, estaduais e federais, da administração direta e indireta, bem como promover inspeções e diligências investigatórias; 
c) requisitar informações e documentos particulares de instituições privadas;

VI - instaurar sindicâncias, requisitar diligências investigatórias e a instauração de inquérito policial, para a apuração de ilícitos ou infrações às normas de proteção ao idoso;

VII - zelar pelo efetivo respeito aos direitos e garantias legais assegurados ao idoso, promovendo as medidas judiciais e extrajudiciais cabíveis;

VIII - inspecionar as entidades públicas e particulares de atendimento e os programas de que trata esta Lei, adotando de pronto as medidas administrativas ou judiciais necessárias à remoção de irregularidades porventura verificadas;

IX - requisitar força policial, bem como a colaboração dos serviços de saúde, educacionais e de assistência social, públicos, para o desempenho de suas atribuições;

X - referendar transações envolvendo interesses e direitos dos idosos previstos nesta Lei.

$\S 1^{\circ}$ A legitimação do Ministério Público para as ações cíveis previstas neste artigo não impede a de terceiros, nas mesmas hipóteses, segundo dispuser a lei.

$\S 2^{\circ}$ As atribuições constantes deste artigo não excluem outras, desde que compatíveis com a finalidade e atribuições do Ministério Público.

$\S 3^{\circ} \mathrm{O}$ representante do Ministério Público, no exercício de suas funções, terá livre acesso a toda entidade de atendimento ao idoso.

Art. 75. Nos processos e procedimentos em que não for parte, atuará obrigatoriamente o Ministério Público na defesa dos direitos e interesses de que cuida esta Lei, hipóteses em que terá vista dos autos depois das partes, podendo juntar documentos, requerer diligências e produção de outras provas, usando os recursos cabíveis.

Art. 76. A intimação do Ministério Público, em qualquer caso, será feita pessoalmente.

Art. 77. A falta de intervenção do Ministério Público acarreta a nulidade do feito, que será declarada de ofício pelo juiz ou a requerimento de qualquer interessado.

\section{CAPÍTULO III}

Da Proteção Judicial dos Interesses Difusos, Coletivos e Individuais Indisponíveis ou Homogêneos

Art. 78. As manifestações processuais do representante do Ministério Público deverão ser fundamentadas.

Art. 79. Regem-se pelas disposições desta Lei as ações de responsabilidade por ofensa aos direitos assegurados ao idoso, referentes à omissão ou ao oferecimento insatisfatório de:

I - acesso às ações e serviços de saúde;

II - atendimento especializado ao idoso portador de deficiência ou com limitação incapacitante;

III - atendimento especializado ao idoso portador de doença infecto-contagiosa;

IV - serviço de assistência social visando ao amparo do idoso. 
Parágrafo único. As hipóteses previstas neste artigo não excluem da proteção judicial outros interesses difusos, coletivos, individuais indisponíveis ou homogêneos, próprios do idoso, protegidos em lei.

Art. 80. As ações previstas neste Capítulo serão propostas no foro do domicílio do idoso, cujo juízo terá competência absoluta para processar a causa, ressalvadas as competências da Justiça Federal e a competência originária dos Tribunais Superiores.

Art. 81. Para as ações cíveis fundadas em interesses difusos, coletivos, individuais indisponíveis ou homogêneos, consideram-se legitimados, concorrentemente:

I - o Ministério Público;

II - a União, os Estados, o Distrito Federal e os Municípios;

III - a Ordem dos Advogados do Brasil;

IV - as associações legalmente constituídas há pelo menos 1 (um) ano e que incluam entre os fins institucionais a defesa dos interesses e direitos da pessoa idosa, dispensada a autorização da assembléia, se houver prévia autorização estatutária.

$\S 1^{0}$ Admitir-se-á litisconsórcio facultativo entre os Ministérios Públicos da União e dos Estados na defesa dos interesses e direitos de que cuida esta Lei.

$\S 2^{\circ} \mathrm{Em}$ caso de desistência ou abandono da ação por associação legitimada, o Ministério Público ou outro legitimado deverá assumir a titularidade ativa.

Art. 82. Para defesa dos interesses e direitos protegidos por esta Lei, são admissíveis todas as espécies de ação pertinentes.

Parágrafo único. Contra atos ilegais ou abusivos de autoridade pública ou agente de pessoa jurídica no exercício de atribuições de Poder Público, que lesem direito líquido e certo previsto nesta Lei, caberá ação mandamental, que se regerá pelas normas da lei do mandado de segurança.

Art. 83. Na ação que tenha por objeto o cumprimento de obrigação de fazer ou não-fazer, o juiz concederá a tutela específica da obrigação ou determinará providências que assegurem o resultado prático equivalente ao adimplemento.

$\S 1^{\circ}$ Sendo relevante o fundamento da demanda e havendo justificado receio de ineficácia do provimento final, é lícito ao juiz conceder a tutela liminarmente ou após justificação prévia, na forma do art. 273 do Código de Processo Civil.

$\S 2^{\circ} \bigcirc$ juiz poderá, na hipótese do $\S 1^{\circ}$ ou na sentença, impor multa diária ao réu, independentemente do pedido do autor, se for suficiente ou compatível com a obrigação, fixando prazo razoável para o cumprimento do preceito.

$\S 3^{\circ}$ A multa só será exigível do réu após o trânsito em julgado da sentença favorável ao autor, mas será devida desde o dia em que se houver configurado.

Art. 84. Os valores das multas previstas nesta Lei reverterão ao Fundo do Idoso, onde houver, ou na falta deste, ao Fundo Municipal de Assistência Social, ficando vinculados ao atendimento ao idoso.

Parágrafo único. As multas não recolhidas até 30 (trinta) dias após o trânsito em julgado da decisão serão exigidas por meio de execução promovida pelo Ministério Público, nos mesmos autos, facultada igual iniciativa aos demais legitimados em caso de inércia daquele. 
Art. 85. O juiz poderá conferir efeito suspensivo aos recursos, para evitar dano irreparável à parte.

Art. 86. Transitada em julgado a sentença que impuser condenação ao Poder Público, o juiz determinará a remessa de peças à autoridade competente, para apuração da responsabilidade civil e administrativa do agente a que se atribua a ação ou omissão.

Art. 87. Decorridos 60 (sessenta) dias do trânsito em julgado da sentença condenatória favorável ao idoso sem que o autor Ihe promova a execução, deverá fazê-lo o Ministério Público, facultada, igual iniciativa aos demais legitimados, como assistentes ou assumindo o pólo ativo, em caso de inércia desse órgão.

Art. 88. Nas ações de que trata este Capítulo, não haverá adiantamento de custas, emolumentos, honorários periciais e quaisquer outras despesas.

Parágrafo único. Não se imporá sucumbência ao Ministério Público.

Art. 89. Qualquer pessoa poderá, e o servidor deverá, provocar a iniciativa do Ministério Público, prestando-lhe informações sobre os fatos que constituam objeto de ação civil e indicando-lhe os elementos de conviç̧ão.

Art. 90. Os agentes públicos em geral, os juízes e tribunais, no exercício de suas funções, quando tiverem conhecimento de fatos que possam configurar crime de ação pública contra idoso ou ensejar a propositura de ação para sua defesa, devem encaminhar as peças pertinentes ao Ministério Público, para as providências cabíveis.

Art. 91. Para instruir a petição inicial, o interessado poderá requerer às autoridades competentes as certidões e informações que julgar necessárias, que serão fornecidas no prazo de 10 (dez) dias.

Art. 92. O Ministério Público poderá instaurar sob sua presidência, inquérito civil, ou requisitar, de qualquer pessoa, organismo público ou particular, certidões, informações, exames ou perícias, no prazo que assinalar, o qual não poderá ser inferior a 10 (dez) dias.

$\S 1^{0}$ Se o órgão do Ministério Público, esgotadas todas as diligências, se convencer da inexistência de fundamento para a propositura da ação civil ou de peças informativas, determinará o seu arquivamento, fazendo-o fundamentadamente.

$\S 2^{\circ}$ Os autos do inquérito civil ou as peças de informação arquivados serão remetidos, sob pena de se incorrer em falta grave, no prazo de 3 (três) dias, ao Conselho Superior do Ministério Público ou à Câmara de Coordenação e Revisão do Ministério Público.

$\S 3^{\circ}$ Até que seja homologado ou rejeitado o arquivamento, pelo Conselho Superior do Ministério Público ou por Câmara de Coordenação e Revisão do Ministério Público, as associações legitimadas poderão apresentar razões escritas ou documentos, que serão juntados ou anexados às peças de informação.

§ 4ํำ Deixando o Conselho Superior ou a Câmara de Coordenação e Revisão do Ministério Público de homologar a promoção de arquivamento, será designado outro membro do Ministério Público para o ajuizamento da ação.

TÍTULO VI

Dos Crimes

CAPÍTULO I

Disposições Gerais 
Art. 93. Aplicam-se subsidiariamente, no que couber, as disposições da Lei $n^{\circ} 7.347$, de 24 de julho de 1985.

Art. 94. Aos crimes previstos nesta Lei, cuja pena máxima privativa de liberdade não ultrapasse 4 (quatro) anos, aplica-se o procedimento previsto na Lei $n^{\circ}$ 9.099, de 26 de setembro de 1995, e, subsidiariamente, no que couber, as disposições do Código Penal e do Código de Processo Penal.

\section{CAPÍTULO II}

Dos Crimes em Espécie

Art. 95. Os crimes definidos nesta Lei são de ação penal pública incondicionada, não se lhes aplicando os arts. 181 e 182 do Código Penal.

Art. 96. Discriminar pessoa idosa, impedindo ou dificultando seu acesso a operações bancárias, aos meios de transporte, ao direito de contratar ou por qualquer outro meio ou instrumento necessário ao exercício da cidadania, por motivo de idade:

Pena - reclusão de 6 (seis) meses a 1 (um) ano e multa.

$\S 1^{\circ} \mathrm{Na}$ mesma pena incorre quem desdenhar, humilhar, menosprezar ou discriminar pessoa idosa, por qualquer motivo.

$\S 2^{\circ}$ A pena será aumentada de $1 / 3$ (um terço) se a vítima se encontrar sob os cuidados ou responsabilidade do agente.

Art. 97. Deixar de prestar assistência ao idoso, quando possível fazê-lo sem risco pessoal, em situação de iminente perigo, ou recusar, retardar ou dificultar sua assistência à saúde, sem justa causa, ou não pedir, nesses casos, o socorro de autoridade pública:

Pena - detenção de 6 (seis) meses a 1 (um) ano e multa.

Parágrafo único. A pena é aumentada de metade, se da omissão resulta lesão corporal de natureza grave, e triplicada, se resulta a morte.

Art. 98. Abandonar o idoso em hospitais, casas de saúde, entidades de longa permanência, ou congêneres, ou não prover suas necessidades básicas, quando obrigado por lei ou mandado:

Pena - detenção de 6 (seis) meses a 3 (três) anos e multa.

Art. 99. Expor a perigo a integridade e a saúde, física ou psíquica, do idoso, submetendo-o a condições desumanas ou degradantes ou privando-o de alimentos e cuidados indispensáveis, quando obrigado a fazê-lo, ou sujeitando-o a trabalho excessivo ou inadequado:

Pena - detenção de 2 (dois) meses a 1 (um) ano e multa.

$\S 1^{\circ}$ Se do fato resulta lesão corporal de natureza grave:

Pena - reclusão de 1 (um) a 4 (quatro) anos.

$\S 2^{\circ}$ Se resulta a morte:

Pena - reclusão de 4 (quatro) a 12 (doze) anos.

Art. 100. Constitui crime punível com reclusão de 6 (seis) meses a 1 (um) ano e multa: 
I - obstar o acesso de alguém a qualquer cargo público por motivo de idade;

II - negar a alguém, por motivo de idade, emprego ou trabalho;

III - recusar, retardar ou dificultar atendimento ou deixar de prestar assistência à saúde, sem justa causa, a pessoa idosa;

IV - deixar de cumprir, retardar ou frustrar, sem justo motivo, a execução de ordem judicial expedida na ação civil a que alude esta Lei;

$V$ - recusar, retardar ou omitir dados técnicos indispensáveis à propositura da ação civil objeto desta Lei, quando requisitados pelo Ministério Público.

Art. 101. Deixar de cumprir, retardar ou frustrar, sem justo motivo, a execução de ordem judicial expedida nas ações em que for parte ou interveniente o idoso:

Pena - detenção de 6 (seis) meses a 1 (um) ano e multa.

Art. 102. Apropriar-se de ou desviar bens, proventos, pensão ou qualquer outro rendimento do idoso, dando-Ihes aplicação diversa da de sua finalidade:

Pena - reclusão de 1 (um) a 4 (quatro) anos e multa.

Art. 103. Negar o acolhimento ou a permanência do idoso, como abrigado, por recusa deste em outorgar procuração à entidade de atendimento:

Pena - detenção de 6 (seis) meses a 1 (um) ano e multa.

Art. 104. Reter o cartão magnético de conta bancária relativa a benefícios, proventos ou pensão do idoso, bem como qualquer outro documento com objetivo de assegurar recebimento ou ressarcimento de dívida:

Pena - detenção de 6 (seis) meses a 2 (dois) anos e multa.

Art. 105. Exibir ou veicular, por qualquer meio de comunicação, informações ou imagens depreciativas ou injuriosas à pessoa do idoso:

Pena - detenção de 1 (um) a 3 (três) anos e multa.

Art. 106. Induzir pessoa idosa sem discernimento de seus atos a outorgar procuração para fins de administração de bens ou deles dispor livremente:

Pena - reclusão de 2 (dois) a 4 (quatro) anos.

Art. 107. Coagir, de qualquer modo, o idoso a doar, contratar, testar ou outorgar procuração:

Pena - reclusão de 2 (dois) a 5 (cinco) anos.

Art. 108. Lavrar ato notarial que envolva pessoa idosa sem discernimento de seus atos, sem a devida representação legal:

Pena - reclusão de 2 (dois) a 4 (quatro) anos.

TÍTULO VII 
Art. 109. Impedir ou embaraçar ato do representante do Ministério Público ou de qualquer outro agente fiscalizador:

Pena - reclusão de 6 (seis) meses a 1 (um) ano e multa.

Art. 110. O Decreto-Lei no 2.848, de 7 de dezembro de 1940, Código Penal, passa a vigorar com as seguintes alterações:

"Art. 61

II -

h) contra criança, maior de 60 (sessenta) anos, enfermo ou mulher grávida;

\section{" (NR)}

"Art. 121.

$\S 4^{\circ}$ No homicídio culposo, a pena é aumentada de $1 / 3$ (um terço), se o crime resulta de inobservância de regra técnica de profissão, arte ou ofício, ou se o agente deixa de prestar imediato socorro à vítima, não procura diminuir as conseqüências do seu ato, ou foge para evitar prisão em flagrante. Sendo doloso o homicídio, a pena é aumentada de $1 / 3$ (um terço) se o crime é praticado contra pessoa menor de 14 (quatorze) ou maior de 60 (sessenta) anos.

" (NR)

"Art. 133.

$\S 3^{0}$

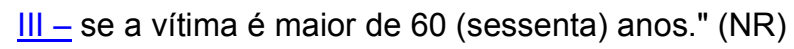

"Art. 140.

$\S 3^{\circ}$ Se a injúria consiste na utilização de elementos referentes a raça, cor, etnia, religião, origem ou a condição de pessoa idosa ou portadora de deficiência:

$(\mathrm{NR})$

"Art. 141. 
IV - contra pessoa maior de 60 (sessenta) anos ou portadora de deficiência, exceto no caso de injúria.

" (NR)

"Art. 148.

$\S 1^{0}$

I - se a vítima é ascendente, descendente, cônjuge do agente ou maior de 60 (sessenta) anos.

." (NR)

"Art. 159

$\S 1^{\circ}$ Se o seqüestro dura mais de 24 (vinte e quatro) horas, se o seqüestrado é menor de 18 (dezoito) ou maior de 60 (sessenta) anos, ou se o crime é cometido por bando ou quadrilha.

.$"$ (NR)

"Art. 183

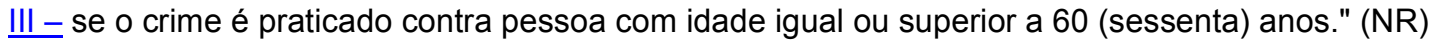

"Art. 244. Deixar, sem justa causa, de prover a subsistência do cônjuge, ou de filho menor de 18 (dezoito) anos ou inapto para o trabalho, ou de ascendente inválido ou maior de 60 (sessenta) anos, não Ihes proporcionando os recursos necessários ou faltando ao pagamento de pensão alimentícia judicialmente acordada, fixada ou majorada; deixar, sem justa causa, de socorrer descendente ou ascendente, gravemente enfermo:

." (NR)

Art. 111. O $\mathrm{O}$ art. 21 do Decreto-Lei $\mathrm{n}^{\circ}$ 3.688, de 3 de outubro de 1941, Lei das Contravenções Penais, passa a vigorar acrescido do seguinte parágrafo único:

"Art. 21

Parágrafo único. Aumenta-se a pena de $1 / 3$ (um terço) até a metade se a vítima é maior de 60 (sessenta) anos." (NR)

Art. 112. O inciso II do $\S 4^{\circ}$ do art. $1^{\circ}$ da Lei $n^{\circ} 9.455$, de 7 de abril de 1997 , passa a vigorar com a seguinte redação:

"Art. $1^{\circ}$ 
$\S 4^{\circ}$

II - se o crime é cometido contra criança, gestante, portador de deficiência, adolescente ou maior de 60 (sessenta) anos;

.." (NR)

Art. 113. O inciso III do art. 18 da Lei $\mathrm{n}^{\circ} 6.368$, de 21 de outubro de 1976 , passa a vigorar com a seguinte redação:

"Art. 18

III - se qualquer deles decorrer de associação ou visar a menores de 21 (vinte e um) anos ou a pessoa com idade igual ou superior a 60 (sessenta) anos ou a quem tenha, por qualquer causa, diminuída ou suprimida a capacidade de discernimento ou de autodeterminação:

" (NR)

Art. 114. $\mathrm{O}$ art $1^{\circ}$ da Lei $\mathrm{n}^{\circ} 10.048$, de 8 de novembro de 2000 , passa a vigorar com a seguinte redação:

"Art. $1^{\circ}$ As pessoas portadoras de deficiência, os idosos com idade igual ou superior a 60 (sessenta) anos, as gestantes, as lactantes e as pessoas acompanhadas por crianças de colo terão atendimento prioritário, nos termos desta Lei." (NR)

Art. 115. O Orçamento da Seguridade Social destinará ao Fundo Nacional de Assistência Social, até que o Fundo Nacional do Idoso seja criado, os recursos necessários, em cada exercício financeiro, para aplicação em programas e ações relativos ao idoso.

Art. 116. Serão incluídos nos censos demográficos dados relativos à população idosa do País.

Art. 117. O Poder Executivo encaminhará ao Congresso Nacional projeto de lei revendo os critérios de concessão do Benefício de Prestação Continuada previsto na Lei Orgânica da Assistência Social, de forma a garantir que o acesso ao direito seja condizente com o estágio de desenvolvimento sócio-econômico alcançado pelo País.

Art. 118. Esta Lei entra em vigor decorridos 90 (noventa) dias da sua publicação, ressalvado o disposto no caput do art. 36, que vigorará a partir de $1^{\circ}$ de janeiro de 2004.

Brasília, $1^{\circ}$ de outubro de $2003 ; 182^{\circ}$ da Independência e $115^{\circ}$ da República.

\author{
LUIZ INÁCIO LULA DA SILVA \\ Márcio Thomaz Bastos \\ Antonio Palocci Filho \\ Rubem Fonseca Filho \\ Humberto Sérgio Costa LIma \\ Guido Mantega \\ Ricardo José Ribeiro Berzoini \\ Benedita Souza da Silva Sampaio \\ Álvaro Augusto Ribeiro Costa
}

Este texto não substitui o publicado no D.O.U. de 3.10.2003 